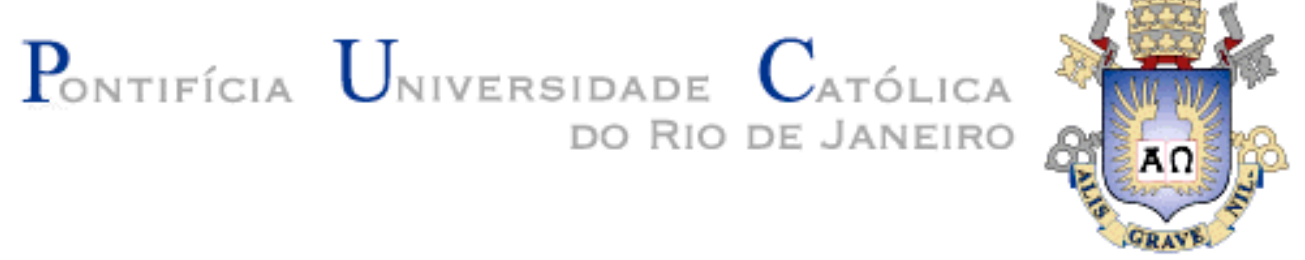

CHRISTINA FUSCALDO DE SOUZA MELO

A/C Zé Ramalho - Eu, ele e a escrita (auto)biográfica

Dissertação apresentada como requisito parcial para obtenção do grau de Mestre pelo Programa de Pós-Graduação em Literatura, Cultura e Contemporaneidade do Departamento de Letras do Centro de Teologia e Ciências Humanas da PUCRio.

Orientador: Prof. Júlio Cesar Valladão Diniz 


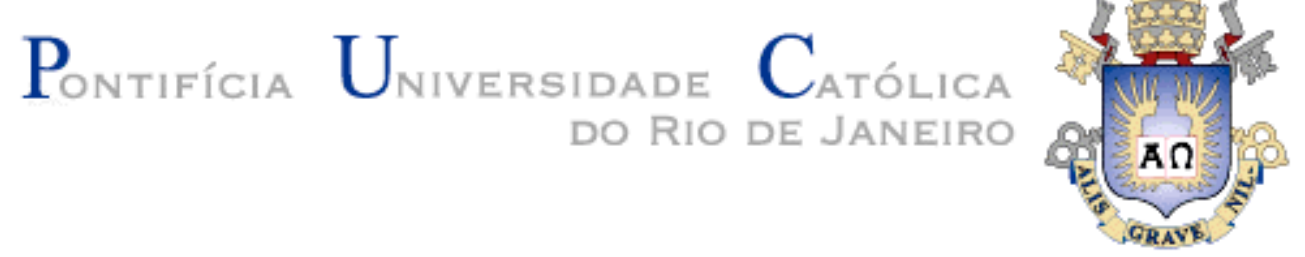

CHRISTINA FUSCALDO DE SOUZA MELO

\begin{abstract}
A/C Zé Ramalho - Eu, ele e a escrita (auto)biográfica
Dissertação apresentada como requisito parcial para obtenção do grau de Mestre pelo Programa de Pós-Graduação em Literatura, Cultura e Contemporaneidade do Departamento de Letras do Centro de Teologia e Ciências Humanas da PUCRio. Aprovada pela Comissão Examinadora abaixo assinada.
\end{abstract}

Prof. Julio Cesar Valladão Diniz Orientador Departamento de Letras - PUC-Rio

Prof. Miguel Jost Ramos Bolsista Pós-Doutorado PUC-Rio/PNPD

Prof. Leandro Garcia Rodrigues CEFET - Petrópolis

Profa. Denise Berruezo Portinari Coordenadora Setorial do Centro de Teologia

e Ciências Humanas - PUC-Rio

Rio de Janeiro, 13 de abril de 2015. 
Todos os direitos reservados. É proibida a reprodução total ou parcial do trabalho sem a autorização da universidade, da autora e do orientador.

\section{Christina Fuscaldo de Souza Melo}

Graduou-se Bacharel em Comunicação Social pelo Centro Universitário da Cidade e Bacharel em Letras pela Universidade Federal Fluminense.

Ficha Catalográfica

Melo, Christina Fuscaldo de Souza
A/C Zé Ramalho - Eu, ele e a escrita
(auto)biográfica / Christina Fuscaldo de Souza Melo;
orientador: Júlio Cesar Valladão Diniz. - 2015.
224 f. : il.(color.) $; 30 \mathrm{~cm}$
Dissertação (mestrado) - Pontifícia
Universidade Católica do Rio de Janeiro, Departamento
de Letras, 2015.
Inclui bibliografia
1. Letras - Teses. 2. Zé Ramalho. 3. Música
Popular. 4. Cultura Brasileira. 5. Ensaio. 6. Biografia. 7.
Carta. I. Diniz, Júlio Cesar Valladão. II. Pontifícia
Universidade Católica do Rio de Janeiro. Departamento
de Letras. Ill. Título.

CDD: 800 


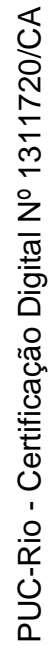

A Zé Ramalho,

ao meu avô e ao meu pai. 


\section{Agradecimentos}

Agradeço a meus pais, Cornélio e Cristina, por terem me ensinado a viver de música e a Marco, meu marido, por ter me ensinado a viver de amor.

Agradeço a meu orientador, Júlio Diniz, por ter me ensinado a pesquisar música na universidade.

Agradeço à PUC-Rio por ter acreditado em meu projeto e ao CNPq e à Capes pelas bolsas de estudo que me possibilitaram pesquisar no Brasil e na Argentina, na Universidade Nacional de Rosário.

Agradeço aos membros da minha banca de defesa, Leandro, Miguel e Paulo, por aceitarem avaliar minha dissertação.

Agradeço aos professores da PUC-Rio Marília Rothier, Daniela Versiani, Vera Follain, Alexandre Montaury e Miguel Jost, e aos da Universidad Nacional de Rosario Sandra Contreras e Alberto Giordano pelo incentivo a meu projeto.

Agradeço às avós Orita e Moema, aos falecidos avôs Cornélio e Francisco, a meu irmão, Felipe, aos jornalistas Ana Maria Bahiana, Jamari França, Luiz Antonio Mello, Adilson Pereira e Mauro Ferreira e aos amigos Hérica Marmo, Erika Azevedo, Taís Salles, Tiago Velasco, Gabriel Rached, Flávio Ojidos e End Marinho (in memoriam), entre outros, por fazerem parte dessa história.

Agradeço a Roberta Ramalho, Tia Zélia, Hugo Leão, Otto Guerra, Bruno Batista, Alceu Valença, Geraldo Azevedo, Lula Côrtes (in memoriam), Amelinha, Fagner, Jorge Mautner, Chico César, Zeca Baleiro, Nelson Motta, José Nêumanne Pinto e todos os outros entrevistados por me possibilitarem contar essa história.

Agradeço a André Cananéa, Silvio Osias, Elinaldo Rodrigues, Eduardo Stucker, Aurílio Santos, Rivanildo Alexandrino, Rozilda Dutra, Mari Lyra, Mari Dantas, Júlio Moura, Zé Ricardo, Kélita Myra, Ana Romeiro, secretaria de Turismo da Paraíba e Prefeitura de Ingá do Bacamarte pela ajuda na produção da pesquisa.

Por fim, agradeço aos fãs de Zé Ramalho, a todos os biógrafos e incentivadores do gênero e a Zé Ramalho por me permitirem contar essa história. 


\section{Resumo}

Melo, Christina Fuscaldo de Souza; Diniz, Julio César Valladão (Orientador). A/C Zé Ramalho - Eu, ele e a escrita (auto)biográfica. Rio de Janeiro, 2015. 224p. Dissertação de Mestrado - Departamento de Letras, Pontifícia Universidade Católica do Rio de Janeiro.

Com uma produção caracterizada por referências literárias e musicais diversificadas, o que a torna um híbrido de influências de apelo transgeracional, Zé Ramalho é o personagem principal de uma biografia autorizada. Através de uma narrativa autobiográfica e com o auxílio de correspondências e entrevistas, este trabalho põe em destaque a importância do cantor e compositor paraibano para a cena musical brasileira e o debate sobre os procedimentos intelectuais e sensitivoafetivos envolvidos na produção do gênero biográfico. Esta dissertação conta uma história que envolve não só o artista e os parceiros com os quais ele se relacionou ao longo da vida como também a pesquisadora, fazendo uma análise da relação entre biógrafa e biografado.

\section{Palavras-chave}

Zé Ramalho; música popular; cultura brasileira; ensaio; biografia; carta. 


\section{Abstract}

Melo, Christina Fuscaldo de Souza; Diniz, Julio César Valladão (Advisor). C/O Zé Ramalho - Me, him and the (auto)biographical narrative. Rio de Janeiro, 2015. 224p. MSc. Dissertation Departamento de Letras, Pontifícia Universidade Católica do Rio de Janeiro.

With a production characterized by diversified literary and musical references, making it a trans-generational hybrid of influences, Zé Ramalho is the main character of an authorized biography. By using an autobiographical narrative, with the aid of correspondences and interviews, this work highlights the importance of the singer and songwriter from Paraíba for the Brazilian music scene and the debate on intellectual procedures and sensory-affective involved in the production of the biographical genre. This Thesis tells a story that involves not only the artist and his partnerships but also the researcher, thus making an additional analysis of the relationship between biographer and biography.

\section{Keywords}

Zé Ramalho; popular music; brazilian culture; essay; biography; letter. 


\section{Sumário}

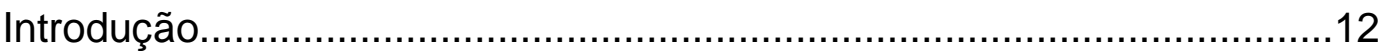

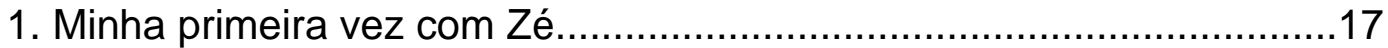

2. A volta para casa, agora acompanhada do Zé....................................22

3. O dia em que vaticinei que escreveria a biografia..............................28

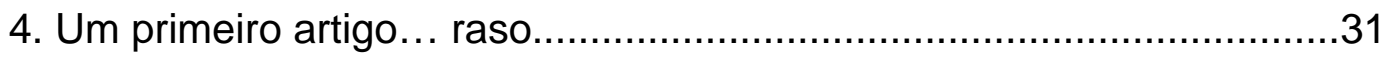

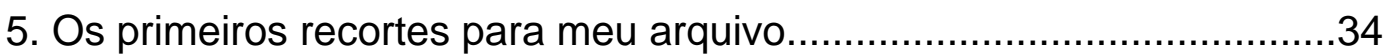

6. A primeira entrevista a gente nunca esquece....................................39

7. A minha primeira entrevista que nunca vou esquecer.........................47

8. Um livro de colagens para convencer Zé Ramalho..............................53

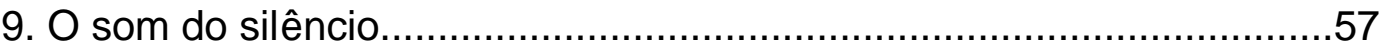

10. Então, ele já sabia que eu era eu.................................................64

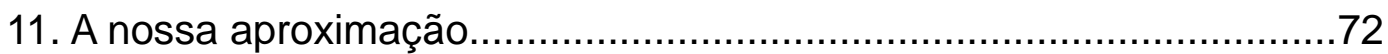

12. Meu arquivo em forma de projeto..................................................

13. A busca por uma editora e mais uma parceria..................................76

14. Um caso rápido com uma editora interessada..................................

15. As consequências de um mercado editorial em crise.........................88

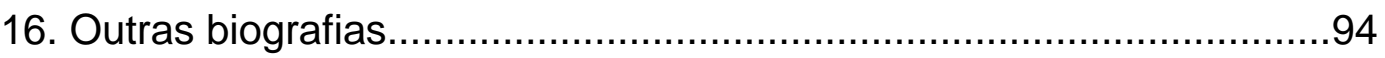

17. Um estágio com a Legião Urbana................................................101

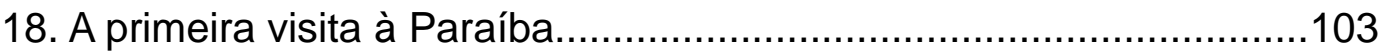


19. Histórias para rir

20. Histórias para para não contar..................................................116

21. O Carnaval do amor e de Lula Côrtes...........................................123

22. A peleja da biógrafa com o mercado editorial................................131

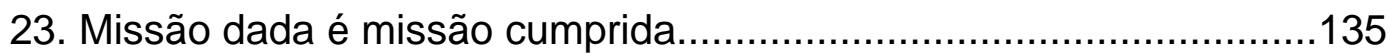

24. A nova parceria com Zé Ramalho e a mudança de rumo.................142

25. A experiência autobiográfica de outros..........................................151

26. A experiência com a morte..........................................................162

27. Um biografado cada vez mais distante de sua biógrafa...................169

28. Investida agressiva, retorno mais rápido......................................179

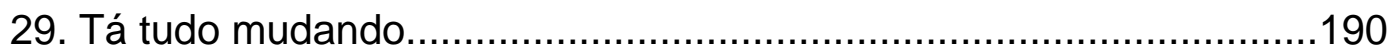

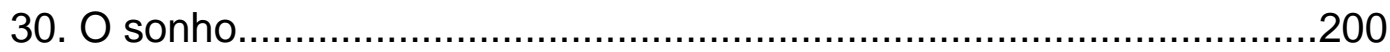

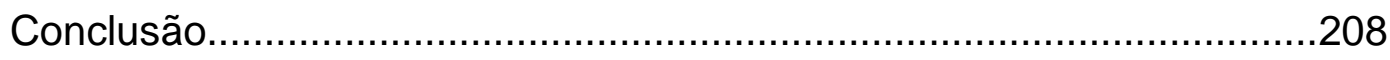

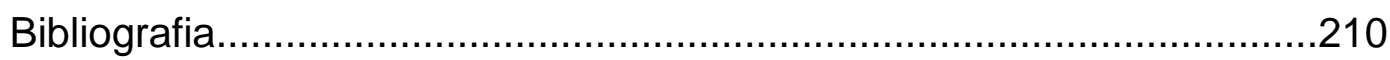

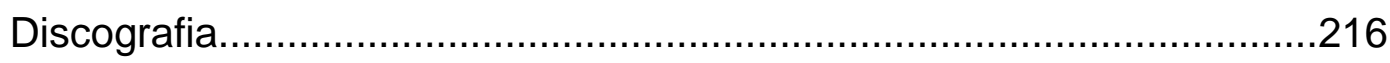

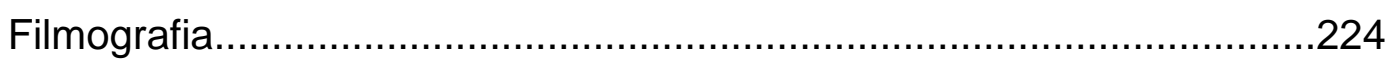




\section{Lista de figuras}

Praça de Cabo Verde (MG) no século XX.........................................19

Artigo sobre Zé Ramalho na revista O Cais............................................33

Cópia do encarte com anotações de Jamari...........................................40

Caixa de CDs de Zé Ramalho autografada............................................40

Eu, Zé Ramalho e Jamari França na Modern Sound, em 2003...............42

Matéria publicada em O Globo Online.................................................

Eu e Zé Ramalho no camarim do Claro Hall, em 2005...........................50

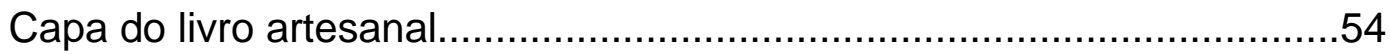

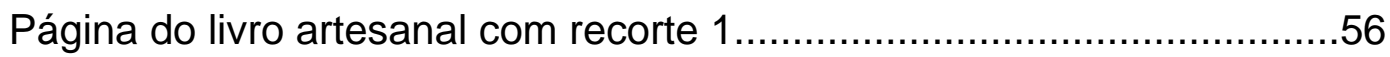

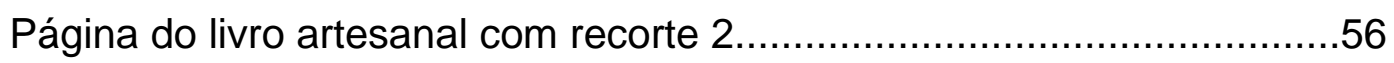

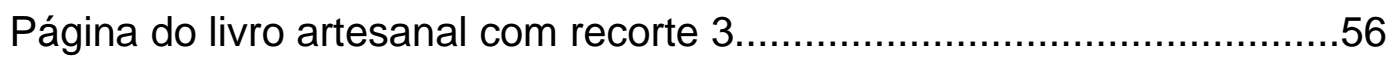

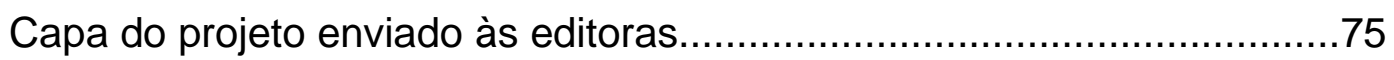

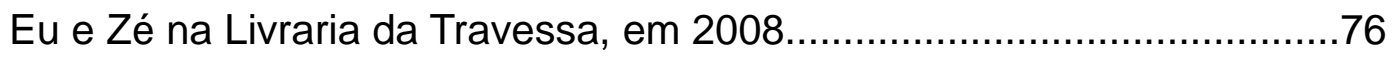

Contracapa do CD "Zé Ramalho da Paraíba" autografada.......................78

Eu e Maurício Baia na capa do CD "Tá tudo mudando"...........................79

Eu entre Babal, Bráulio Tavares e Maurício Baia.....................................79

Matéria publicada no Jornal da Paraíba...............................................113

Retrato de José Alves Ramalho, o Avôhai..............................................116

Retrato de Maria Soledade Pordeus Ramalho.....................................116

Zé Ramalho posando de modelo para a marca Curral............................124

Contracapa e capa de "Paêbirú" com Zé Ramalho e Lula Côrtes..........124

Entrevista publicada no jornal O Globo...............................................133

Errata do MSN sobre a notícia da morte.............................................165

Parte da matéria publicada no GarotaFM...........................................171

Matéria publicada no jornal O Dia....................................................188

Matéria sobre o show Fagner e Zé Ramalho no GarotaFM....................193

O registro de momentos da pesquisa.................................................207 
A gente não deve permitir que as cartas se tornem obsoletas, mesmo que talvez já tenham se tornado.

Paula Dip, Para Sempre Teu, Caio. F.

Ele, eu, todos enfim, temos essa nostalgia que nos faz rever a torre da igreja, as paredes brancas do cemitério, os atalhos verdes semeados de florinda. Mas a gente reage, faz-se forte e... fica.

Graciliano Ramos, Cartas.

Para o vagabundo, o corpo é o lugar que escolheu para viver as suas desavenças com a sociedade. Transferi o lugar das minhas desavenças para a folha de papel, assim como o político progressista no Brasil teve de transferi-lo para a arena política.

Se o corpo do vagabundo é sofrido, os meus escritos também o são, e a luta política dos progressistas também o é. Às vezes, chamam-me de pessimista. Não o sou. Ou melhor: visceralmente não o sou. Quem o é são os meus escritos.

Silviano Santiago, Em Liberdade.

O livro é uma mistura incrível. Tem tudo lá dentro. Crítica, teoria, psicologia e até romance: sou eu. $E$ eu pesquisador.

Mário de Andrade, Cartas a Manuel Bandeira. 


\section{Introdução}

Rio de Janeiro, 15 de março de 2015.

Caros membros da banca,

O meu nome, vocês já sabem. Que eu sou uma jornalista formada em Letras e em Comunicação, talvez não. Como se deu a jornada pela busca de mais conhecimento sobre a trajetória de Zé Ramalho desde o momento em que me apaixonei por uma de suas canções, o que acabou por me tornar uma pesquisadora autorizada a escrever uma biografia do artista, vocês saberão lendo esta dissertação. Mas, em primeiro lugar, eu gostaria de fazer uma pequena introdução através da qual pretendo apresentar os principais pontos deste trabalho.

No conto "Conversei ontem à tardinha com o nosso querido Carlos", publicado no liuro "Histórias mal contadas - Contos", o escritor Silviano Santiago escreve uma carta para Mário de Andrade, na qual discursa sobre uma conversa que teria tido com Carlos Drummond de Andrade a respeito de uma correspondência enviada pelo primeiro ao poeta modernista de São Paulo. Silviano propõe a Mário debates sobre a interpretação da carta pelo poeta mineiro e sobre a mudança em seu comportamento após a leitura dos escritos enviados pelo amigo, ao mesmo tempo em que emite opiniões e expõe reflexões sobre a relação dos dois personagens. O texto é um pastiche das cartas que Mário escrevia a diversos destinatários, entre eles Drummond, e é também um simulacro, pois não poderia ter sido produzido no ano destacado no espaço reservado para a data, no alto da primeira página: "Bh, junho de 1925" (SANTIAGO, 2005, p. 157). Pela abreviação, pela falta do dia, pela ausência dos endereços do remetente e do destinatário e, também, pela 
maneira como Silviano evoca o escritor - "Mário dear" - percebe-se que é uma carta informal e ficcional. Ao longo desse texto, o autor imprime marcas autobiográficas, misturando informações pessoais a outras questões, e, no final, confessa não estar certo se tais escritos são mesmo sobre Mário e Carlos ou se sobre si mesmo.

Na "Nota do editor" de seu liuro "Em liberdade", Silviano conta que recebeu os originais de um diário, que teria sido escrito por Graciliano Ramos depois de deixar a cadeia, e que decidiu transformá-los em um livro. Como o legítimo dono do material, segundo o editor um velho amigo do escritor alagoano, preferiu não ter seu nome revelado, Silviano assume a responsabilidade pela publicação. O nome de Graciliano não aparece na capa do livro, apenas nesta introdução e nas páginas que se seguem. Mas a folha de rosto traz uma informação que me levou a crer que todo conteúdo teria sido escrito pelo próprio Silviano: "Uma ficção de Silviano Santiago".

Em "A Mulher Calada - Sylvia Plath, Ted Hughes e os limites da biografia", a jornalista e escritora norte-americana Janet Malcolm examina todas as biografias publicadas sobre a poeta, conterrânea sua que se radicou na Inglaterra, e sobre a relação dela com o poeta britânico com quem foi casada, confrontando umas com as outras e com a sua própria pesquisa. Seu trabalho resultou em uma análise sobre a relação entre biógrafos e biografados e, assim, numa discussão bastante esclarecedora dos procedimentos intelectuais e sensitivo-afetivos envolvidos na produção desse gênero. Janet Malcolm inicia seu trabalho como biógrafa e acaba se colocando como personagem coadjuvante da trama que narra a saga de uma jornalista em busca de dados para a produção de uma biografia de Sylvia Plath, comentando fatos da vida e relacionando-os à produção da obra da poeta.

No caso de "Para sempre teu, Caio F.", Paula Dip mistura memórias do que viveu ao lado do amigo e parceiro Caio Fernando Abreu à narração de histórias sobre o escritor gaúcho, falecido em 25 de fevereiro de 1996. Para traçar o perfil de Caio, a jornalista recorre a seus textos e a cartas trocadas por ele e profissionais do meio jornalístico, poetas, artistas, familiares e 
amigos. Na introdução, Paula afirma que não se trata de uma biografia de Caio Fernando Abreu, mas de uma "tentativa" de registrar a amizade dos dois.

Assim como Malcolm, quando ouvi pela primeira vez uma canção de Zé Ramalho, músico do Nordeste brasileiro que tem uma produção caracterizada por referências literárias e musicais com as quais me identifico, senti um desejo incontrolável de investigar a história desse artista paraibano. Eu já era uma devoradora de biografias e, assim como Mário de Andrade e Graciliano Ramos faziam com seus amigos mais próximos, tentei iniciar o diálogo com Zé através de correspondência, ao mesmo tempo em que comecei a me dedicar por conta própria à investigação sobre a vida e a obra dele. 0 objetivo era convencê-lo de que eu poderia me tornar sua biógrafa e contar sua verdadeira história. Zé Ramalho deixou que eu me aproximasse. Durante o trabalho que fiz para um de seus álbuns, concedeu-me a autorização - exigida para publicações do gênero no mercado editorial brasileiro - e auxiliou-me em parte da pesquisa. Eu disse "parte".

Assumindo a postura de sujeito contemporâneo que Michel Foucault descreve como um sujeito atravessado pela cultura, pela sociedade e pelas relações de poder, que se afirma enquanto indivíduo e permanece sujeitado aos acontecimentos históricos, Zé Ramalho é um dos expoentes da cena musical contemporânea desse país cuja produção artística é tão diversificada, além de ser um músico com tendência ao gosto pela experimentação. Ele nasceu em 03 de Outubro de 1949, em Brejo do Cruz, sertão da Paraiba, morou em Teixeira e em Campina Grande e passou a maior parte de sua adolescência em João Pessoa, de onde saiu para o Rio de Janeiro em busca de reconhecimento, este que veio em 1978 através do lançamento de seu primeiro álbum.

Eu fui criada em uma casa musical e, quando decidi me tornar jornalista e trabalhar para veículos de comunicação, foi natural o meu encaminhamento para a editoria de cultura, onde me especializei em escrever sobre artistas e movimentos do mundo da música. Passei anos buscando uma editora que se interessasse pelo meu projeto. Enquanto isso, trabalhei em outros discos de Zé Ramalho. As dificuldades me fizeram pensar em desistir, mas meu arquivo já era rico demais para eu engavetá-lo assim. 
Segui me dedicando sozinha ao livro e, com o aprofundamento da minha pesquisa no Departamento de Letras da PUC-Rio, cujo programa Literatura, Cultura e Contemporaneidade abraça os estudos de perspectivas construtivistas e as relações com os "processos de leitura, historiografia e etnografia" (VERSIANI, 2010, p. 43) e, por isso, considerei ideal para os estudos a que escolhi me dedicar quando decidi ingressar no mestrado, pude perceber não só que a investigação em busca de uma verdade seria inviável e, assim, ilusória, mas também que as cartas e e-mails que escrevi para Zé Ramalho contam uma história que envolve não só ele e os parceiros com os quais se relacionou ao longo da vida, como também a mim. Sendo assim, uma biografia sem uma revisão crítica dos procedimentos utilizados pelos jornalistas não me levaria ao questionamento (auto)crítico que eu desejava. Descobri que, através de uma narrativa autobiográfica, onde me insiro como receptora atenta das canções, como remetente de cartas e emails destinados a Zé e outros personagens e como destinatária de cartas e e-mails enviados por parceiros do artista, faria uma crítica dessa trajetória, sem deixar de reconhecer o potencial ficcional das informações coletadas.

Para isso, dividi a dissertação em 30 capítulos, nos quais entrelaço a história da minha formação como biógrafa à trajetória do meu biografado em textos escritos em primeira pessoa e usando a correspondência, seja através de cartas ou e-mails, como recurso para uma aproximação desses dois mundos.

Quebrando alguns paradigmas acadêmicos, busquei uma fonte distinta para aproximar a impressão das cartas à letra de meus manuscritos, assim como distingui os formatos das citações de trechos de entrevistas e de matérias jornalisticas que utilizei nos textos autobiográficos das que ilustraram temas abordados nas cartas. Até publicações próprias minhas como jornalista permeiam essa dissertação. Mário de Andrade diria que tem tudo aí dentro, inclusive fição. Assim como Silviano Santiago, modifiquei o tempo e o espaço de alguns personagens dessa história para que ela fizesse mais sentido. 
Os pressupostos da recepção permearam meus estudos, assim como outras questões da contemporaneidade. Para não deixar de comentar as outras biografias publicadas sobre Zé Ramalho em forma de liuro ou filme, utilizei alguns dos princípios da crítica biográfica. Debati também, só que com o próprio artista através das mensagens que enviei e das que não enviei, alguns dos valores de sua arte e a desvalorização da mesma por críticos especializados. Muitas referências não estão claras em citações, mas podem ser percebidas em nuances do texto. Trabalhar com as teorias do gênero epistolar não foi uma opção simplesmente pelo fato de que as epístolas, ou seja, as cartas foram utilizadas apenas como um recurso para mostrar a forma como me relaciono com meu biografado.

Espero que tenha alcançado o meu objetivo de, abandonando a narração "heterodiegética" e assumindo a "autodiegética", nos termos de Philippe Lejeune, permear a escrita da dissertação com nuances que abordam minha relação com Zé Ramalho, como jornalista e admiradora de sua obra, construindo um perfil pessoal e profissional do meu objeto de estudo e trabalhando a construção da minha presença e da dele como personagens dessa narrativa.

Atenciosamente,

Christina Fuscaldo 


\section{Minha primeira vez com Zé}

Lembro-me até hoje da sensação que "Avôhai" me causou naquela noite fria. Cabo Verde é um município com menos de 15 mil habitantes, cuja principal atividade econômica é o café. É uma cidade daquelas que têm algumas praças, sendo uma delas a principal, um coreto e uma Igreja, que viram sede para os encontros de seus habitantes e de forasteiros como eu. Apesar de ter raízes e algo de cabo-verdiano em meu sangue, sempre fui uma estrangeira na cidade do meu avô. Minhas roupas, os acessórios, as cores do meu cabelo, o sotaque, as gírias niteroiense-cariocas e as vivências que eu tinha para contar sempre me diferenciaram do povo daquele lugar. E não era difícil comparar porque sempre tive primos da mesma idade, porém muito diferentes de mim. Também pudera... Naquela época em que éramos crianças e adolescentes, não existia esse papo de globalização! Comecei a sentir as mudanças por lá quando a internet alcançou o interior de Minas Gerais, acho que na primeira década do século XXI. Mas nessa época, eu já não frequentava Cabo Verde como antigamente.

Eu viajava bastante para lá, quando criança, com meus pais e irmão e, muitas vezes, minha tia e avó paterna iam também. Na virada da infância para a adolescência, o ritmo diminuiu. Passamos alguns anos sem visitar os parentes e, aos 14 , senti saudades e pedi a meu pai para voltarmos. Fomos a Cabo Verde dois anos consecutivos e, bem na época em que me apaixonei por um rapaz da cidade, filho da mulher com quem meu pai namorou em sua juventude, paramos de viajar novamente. Meu pai, acho, já estava cansado da longa estrada e do pouco que tinha para fazer lá. Ele gostava de matar as saudades dos primos, mas, ele conseguia fazer isso por telefone, esperando a linha e discando os números que sucediam o DDD 35. Hoje, refletindo, fico imaginando o que isso tudo devia significar para minha mãe, uma mulher urbana que nunca gostou de muita aventura e sempre adorou circular elegante, bem vestida e maquiada. Devia ser uma tortura passar dias num lugar tão isolado e empoeirado. 
Engraçado... Também acho que, ao perceberem que eu estava criando asas e aproveitando "mais do que devia" a cidade e seus cidadãos, meus pais acharam melhor evitar a frequência. Cinco meses depois de alcançar meus 18 anos, completados em 31 de agosto de 1998, dei um grito de liberdade e fui para Cabo Verde de ônibus, com uma das minhas primas mineiras, que veio me visitar acompanhada do tio Zé, o primo mais próximo do meu pai, e Cristina, sua esposa. Elaine viu o mar pela primeira vez naquela viagem a Niterói. Estrategista, convenci Zé e Cristina a deixarem-na comigo mais uns dias e, no retorno dela para Cabo Verde, convenci meus pais de que eu tinha que ir junto para acompanhá-la. Foi minha primeira aventura e um marco em minha história. A partir dali, em todas as férias e feriados, eu pegava o ônibus da Viação Cometa que saía depois das $23 \mathrm{~h}$ e levava oito horas até Poços de Caldas. Depois, enfrentava mais uma hora de estrada para chegar a "Green Cable" (como eu e meus primos brincávamos de chamar a cidade), no carro sempre imundo de terra da roça do Zé, a quem passei a chamar de "meu pai mineiro", visto que era ele quem me abrigava e cuidava de mim quando eu estava lá.

Toda noite, eu ia para a praça para tocar violão e cantar com os primos, amigos dos primos e primos dos amigos dos primos. A minha chegada era sempre um acontecimento, afinal, nenhuma das primas cantavam e, por isso, só eu poderia interpretar as vozes femininas da música sertaneja nos duetos com os rapazes: Sandy e Roberta Miranda eram as principais. Só que, além de superar as expectativas da rapaziada, eu também satisfazia meus desejos de mostrar a eles meus conhecimentos sobre música "urbana" e, de alguma forma, "colonizar" um pouco o gosto deles. E tocava Marisa Monte, Zélia Duncan, Kid Abelha, Lobão, Paralamas do Sucesso, Legião Urbana, que eu aprendia nas minhas aulas de violão em Niterói, e mais o que meu pai me ensinava de rock sessentista: Beatles, Rolling Stones e afins. E, assim, íamos trocando figurinhas madrugada adentro. Da praça, passávamos para trás da Igreja, onde ficava um quiosque que vendia "lanches" com direito à escuta de sucessos selecionados pelo homem que fazia os sanduíches. Quando o dono fechava as janelas, migrávamos para a calçada do Banco do Brasil, a única agência da cidade. E, lá pelas $5 \mathrm{~h}$, despedíamos-nos e íamos embora. Muitas vezes, encontrei o Zé 
saindo para a roça. Em algumas delas, fui junto, virada, para passar o dia com minha tia-avó Dirce, com seu marido, o tio Lico, e com a prima Má (Márcia Helena). Eu chegava na fazenda, tomava o café da manhã com a família e ia dormir no quarto de um deles. Assim, além de aguentar os passeios vespertinos pelas plantações de café, pelas hortas ou pelos currais, chiqueiros e galinheiros, eu me preparava para a próxima noitada que viria pela frente.

Foi numa dessas noites de janeiro de 1999 que, sentada com minha turma numa das mesas do quiosque, esperando meu lanche sair, escutei uma voz grave que me arrepiou dos pés à cabeça. De repente, eu me senti acompanhada daquela música. Ou melhor, a sensação de solidão com a qual eu sempre tinha convivido foi embora e, meio em transe, segui a harmonia e a melodia do início ao fim sem me preocupar em entender o que o cantor dizia. No fim, perguntei

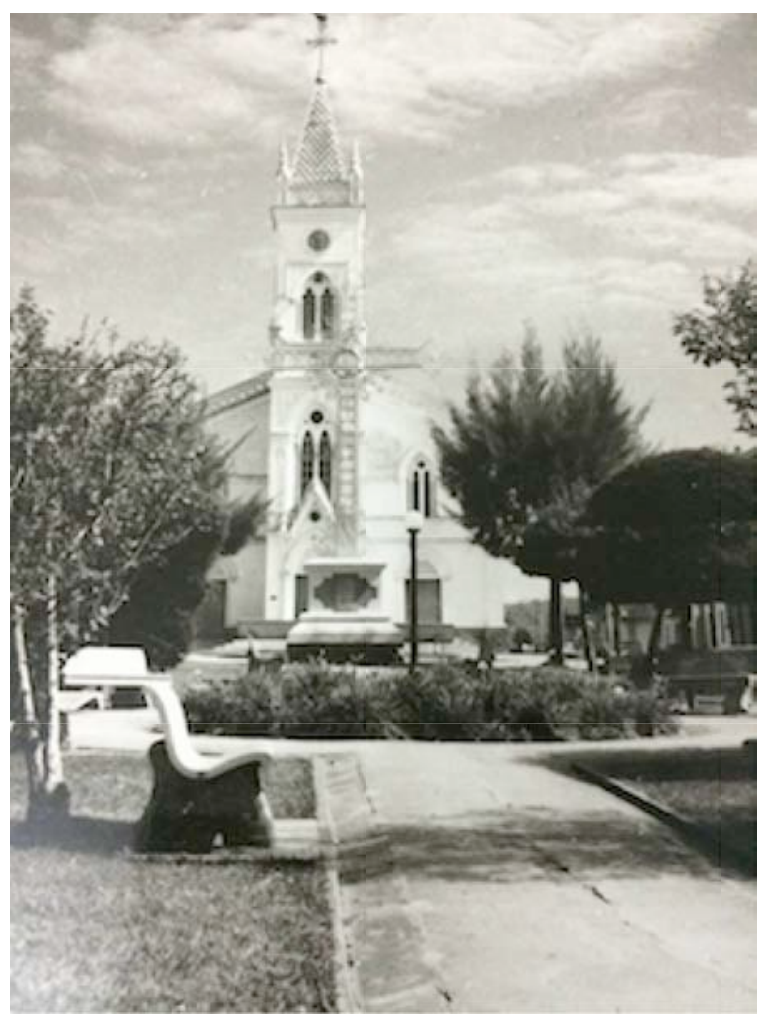
de quem era aquela voz. "Zé

Ramalho", disse um dos meus amigos. "De onde?", eu quis saber. "Da Paraíba", respondeu ele. Ali, naquela madrugada, foi anunciada a grande virada da minha vida. Quando cheguei na casa do Zé, meu "pai mineiro", em vez de me atracar com meu diário, peguei um caderno em branco que tinha levado comigo, rabisquei bem grande na capa "A/C Zé Ramalho" e comecei a escrever uma carta para aquele cara que eu não conhecia, mas que acabara de despertar em mim uma nova paixão: a sua história. Zé Ramalho trouxe de volta o sonho de adolescência de me tornar uma escritora de biografias. 
Cabo Verde, 22 de janeiro de 1999.

\section{Caro Zéramalho,}

Você não me conhece nem eu te conheço. Decidi te escrever porque acabei de ouvir a sua voz e percebi como você a usa para cantar uma canção. É sua essa música em que fala um monte de palauras estranhas, coordenando-as em frases esquisitas e, em certo momento, mais especificamente no refrão, usa uma expressão surreal, algo como "avôrrai"? Não entendi nada, mas amei. Senti o que sentia quando, mais nova, passava pela sala de música lá de casa e, aproveitando-me um pouco do hobby do meu pai, ouvia algum rock inglês ou americano junto com ele e não entendia uma palaura. Hoje, já formada em inglês, compreendo muito melhor as rimas fáceis dos Beatles e as letras mais abusadas dos Rolling Stones. Mas, mesmo falando a sua lingua, o "brasileiro" que Mário de Andrade tanto se orgulhava de escrever, não compreendi o verso "o meu velho indivisivel avôrrai." Você me explicaria?

Sei que não tem como fazer isso agora e sei que eu deveria esperar o momento certo para fazer tal pergunta, mas preferi escrever para que não me esqueça da sensação que me causaste nesta madrugada de quinta para sexta-feira. A canção me fez lembrar de Hélio Oiticica... Olho para uma escultura dele e, em vez de focar na obra como um todo, fico procurando as referências que ela contém. É como se tivesse escutado uma canção enigmática e, agora, estou aqui tentando encontrar as minhas referências musicais que nela podem estar contidas.

Estou em Cabo Verde, cidade no Sul do Estado de Minas Gerais de onde meu avô paterno saiu quando decidiu estudar Medicina em Niterói. Foi lá do outro lado da ponte Rio-Niterói que o velho Cornélio - falecido poucos meses após meu nascimento - casou-se com minha avó Orita e deu à luz meu pai, que também se chama Cornélio e formou a familia na qual eu fui gerada. Mas foi aqui em Cabo Verde que sua voz me emocionou. Apesar de estar rodeada de amigos, 
sentia-me sozinha. Os primeiros acordes mexeram comigo e, quando você começou a cantar, deu uma vontade de chorar danada! E não é que, mais para o final da música, eu estava muito mais leve? Eu me senti acompanhada da sua canção e daquela voz grave de trovador cantando uma música de letra incompreensivel por cima de uma harmonia simples, mas ao mesmo tempo rebuscada com a qual não estou acostumada. Não sou uma fã qualquer, mas uma pessoa dotada de sensibilidades auditivas. Talvez por ter sido criada no meio da música, com pai e irmão autodidatas nos instrumentos típicos do rock e com uma avó que, até hoje, aos 83 anos, toca sambas clássicos ao piano. Tentei me concentrar na sensação que sua voz me causava sem pensar na origem da música ou na carga de suas mensagens, afinal, além de não entender muitas das palauras que cantava, eu também não faço ideia de quem é você. Já sei seu nome e de onde você vem, mas continuo me sentindo presa à minha ignorância, afinal, nunca fui à Paraíba...

Bom, Zérramalho, já são quase 6 h e eu preciso dormir. Hoje não fui para a roça com Zé, meu pai mineiro, porque queria escrever, ou melhor, queria te escrever, para me apresentar e para tentar te conhecer melhor. Mas, como você não é uma criação minha - como é o destinatário para quem escrevo as páginas do meu diário - mas uma figura real, não posso inventar suas características e imaginar suas experiências. Ficarei na expectativa de conseguir mais informações quando chegar em Niterói. Meu pai, com certeza, vai saber me dizer quem é você.

Ah, e antes que eu me esqueça, tenho 18 anos e estou prestes a começar a cursar a faculdade de Jornalismo no Rio. Meu nome é Christina Fuscaldo de Souza Melo, mas aqui em Cabo Verde todos me chamam de Christininha.

Um abraço,

Christininha 


\section{A volta para casa, agora acompanhada do Zé}

Eu tinha uns 15 anos quando passei a ler as histórias dos outros. Até aquele momento, para mim, eram todas reais. Acho que por causa do meu histórico familiar, comecei lendo biografias de músicos. Antes de me interessar por esses personagens, eu conhecia os poemas de Fernando Pessoa, os romances de Machado de Assis, as ficções policiais de Agatha Christie e outras narrativas desses gêneros. Essas influências vieram de todos os lados: do garimpo em bibliotecas familiares, das dicas dos colegas da escola, da descoberta solitária em viagens por enciclopédias, jornais, revistas e até outros livros em uma época em que não existia internet. Li muito menos do que devia ter lido. $\mathrm{Na}$ época do segundo grau, mudei de uma escola mais conservadora para uma experimental. Minha mãe é de uma família tradicional da sociedade niteroiense, a família de imigrantes italianos Fuscaldo que prosperou após fundar, na cidade, a fábrica de massas Fuscaldesa. Mas eu, apesar de sempre ter vivido em uma condição financeira confortável, nunca me senti muito bem ao lado de pessoas que não se preocupavam com o mundo ao redor. No primeiro grau, fugia das colunas sociais. Sentia-me avessa a qualquer publicidade como Graciliano Ramos e, como Mário de Andrade, às "más companhias": "Meu grupo, amigos, camaradas, todos ricaços, sem preocupações. Há um eterno conflito entre mim e êles." (ANDRADE, 2001, p. 37) A diferença é que eu refletia calada, sem expor meus sentimentos aos de fora. No novo colégio, deparei-me com alunos muito menos preparados para o vestibular do que eu, porém muito mais sagazes em relação à vida. E eles liam muito. Liam livros de filosofia, de sociologia, de história, de geografia, de política, de teatro, de música, de literatura brasileira, de literatura francesa... De repente, entrei em uma corrida contra o tempo na tentativa de recuperar o déficit literário que sentia. Li muito mais coisas naqueles três anos do que havia lido a vida inteira. E, também neste momento, comecei a ler biografias. 
Acostumada a acompanhar meu pai, engenheiro e músico nas horas vagas, em sessões caseiras de transmissão de vídeos - em que as fitas VHS importadas com documentários sobre a vida e a obra de astros como Jimi Hendrix, John Lennon e Janis Joplin eram nossa maior diversão - passei a ter sede de matérias jornalísticas, especiais em revistas de música e livros sobre nomes da cena musical. Já que esses artistas não contavam histórias, apenas cantavam algumas que eu não sabia se eram próprias ou inspiradas em outros personagens, passei a querer entender a obra a partir da trajetória de cada um. $E$, assim como a jornalista Janet Malcolm, quando iniciou sua investigação sobre a poetisa norte-americana Syvia Plath, "comecei a sentir os primeiros sintomas da infecção: a manifestação inconfundível do desejo investigatório" (MALCOLM, 1994, p. 36). Li sobre todos os estrangeiros que conhecia só de ouvir na vitrola de casa e de ver nas fitas de vídeo do meu pai e comecei a formular a hipótese de que o comportamento de cada um na vida privada influenciava na sua canção. E, junto com a paixão pela música brasileira, que eclodiu em mim de uma hora para a outra, veio também a vontade de ler sobre meus novos ídolos nacionais. Descobri Caetano Veloso e Gilberto Gil e suas histórias sobre o exílio em discos e livros, entre eles o "Tropicália - A história de uma revolução musical"1. Li sobre outros movimentos em publicações como "BRock - o Rock Brasileiro dos Anos 80". Acompanhei a eclosão de fenômenos como Marisa Monte e Daniela Mercury pela imprensa, juntando recortes de revistas e jornais a fim de fazer em corte e colagem a minha própria versão da biografia dessas cantoras. Madonna era uma influência da minha infância, mas foi na adolescência que comecei a selecionar trechos de matérias jornalísticas que contassem histórias da cantora americana. Comecei a montar meu arquivo.

É preciso que o poder arsônico, que concentra também as funções de unificação, identificação, classificação caminha junto com o que chamaremos o poder de consignação. Por consignação não entendemos apenas, no sentido corrente deste palavra, o fato de designar uma residência ou confiar, pondo em reserva, em um

1 A Editora 34 lançou, durante a década de 90, a coleção Ouvido Musical, cujos livros tinham supervisão do crítico musical Tárik de Souza e contavam com outros nomes do jornalismo como autores das histórias de movimentos e grupos que fizeram a história da música no Brasil. "Tropicália - A história de uma revolução musical" e "BRock - o Rock Brasileiro dos Anos 80" foram dois dos livros lançados pela editora, assim como "A divina comédia dos Mutantes". 
lugar e sobre um suporte, mas $o$ ato de consignar reunindo os signos. (DERRIDA, 2001, p. 14).

Já pensando em começar a recortar algo também sobre o Zé Ramalho, ao voltar de Cabo Verde, corri para perguntar a meu pai se ele conhecia o músico. Descobri que tínhamos em casa dois LPs e um CD duplo. No encarte de dois dos discos, li o nome da canção que eu havia escutado em Minas: "Avôhai". E ouvi do meu maior professor de música que o artista tinha aparecido na cena musical brasileira na década de 1970 mais ou menos ao mesmo tempo em que surgiram outros nomes nordestinos, entre eles Fagner, seu favorito, Elba Ramalho, Alceu Valença e Geraldo Azevedo. Perguntei se, em sua coleção de revistas de música, havia alguma matéria sobre o Zé e ele disse que achava que não. Agradeci, mas de certa forma me decepcionei ao perceber que meu gosto musical já não era tão parecido com o do meu pai. Ele disse que gostava do Zé, mas me pareceu que gostava menos do que eu queria que ele gostasse. Eu me dei conta de que nem Zé nem Marisa Monte nem Caetano Veloso nem Madonna tocavam em sua vitrola e muitas fichas começaram a cair. Quando me via colando meus recortes nos cadernos, meu pai achava lindo. Tanto que chegava a comprar revistas nas quais sabia que eu encontraria novos textos e fotos. Nesse episódio em que descobri que Zé Ramalho não era um dos nossos elos musicais, percebi que o Cornelinho - é assim que minha avó, do alto de seus 99 anos, o chama até hoje - entrava no meu jogo talvez para não me decepcionar. Ao perceber que na busca pelo Zé Ramalho estaria sozinha, até porque com 18 anos eu já me virava com minha mesada, fiquei angustiada. Depois da conversa com meu pai, que sentado à frente da vitrola ficou, corri para o meu quarto e abri o caderninho para escrever minha segunda carta para o Zé Ramalho. 
Niterói, O6 de fevereiro de 1999.

\section{Olá, Zé!}

Preciso desabafar e tem que ser com você, afinal, desde que ouvi "Avôhai" - agora sei o nome da música e, também, que é de sua autoria - não consigo relaxar. E a culpa é sua! Cheguei da viagem e corri para perguntar a meu pai sobre você. Ele me contou que sempre te admirou e que até tocava uma canção sua nas rodas de violão que fazia na década de 80, "Admirável gado novo", um hit na época do lançamento do álbum "A peleja do diabo com o dono do céu". Lembrei que essa música voltou a fazer muito sucesso há mais ou menos três anos, quando virou tema da Luana, personagem de Patrícia Pillar na novela $O$ Rei do Gado. Raramente eu assistia a algum capítulo, porque, no segundo grau, além de estudar em tempo integral, tinha muitas atividades paralelas ao colégio. Chegava em casa muito cansada, mas lembro de ficar muito emocionada quando, durante o jantar, via na TV pequena da cozinha aqueles sem-terra invadindo as fazendas ao som de uma música de protesto. Acabo de me dar conta de que eu nunca perguntei de quem era aquela composição... Apesar de meu pai viver dizendo que eu parecia Patrícia Pillar naquela novela, eu confesso que tinha um pouco de resistência à televisão. Quando compôs "Admirável gado novo", você não estava pensando em sem-terras, né? Acho que nem se falava nisso na sua época... Mas aposto que pensou nas pessoas que Aldous Huxley imaginou como personagens do liuro "Admirável mundo novo", condicionadas a viverem em harmonia com as regras de uma sociedade organizada por castas. Aposto que você associou essa gente ao povo trabalhador do Nordeste. Voltando à novela, uma frase que nunca saiu da minha cabeça foi a dita pelo fazendeiro Bruno Mezenga, interpretado por Antonio Fagundes, ao Senador Caxias, vivido por Carlos Vereza, quando este comentou que não lidava com boi: "Mas lida com o povo. Um e outro não 
sabem a força que tem!" Fiquei curiosa para saber se a canção chegou a correr risco de censura, afinal, em 1980, havia a Ditadura e a arte brasileira ainda estava reprimida.

Meu pai não tem muitos discos seus nem soube me falar sobre sua história. Fiquei triste. Poxa, estou falando do cara que me apresentou a tudo! Como eu posso estar apaixonada por um artista e ele não? Meu pai foi (e ainda é) meu tutor, meu maior incentivador em todos os assuntos relacionados à música. Quando nasci, ele já tinha tido duas bandas relativamente famosas no circuito niteroiense nas décadas de 60 e 70 e mantinha o hábito de tocar violão e piano junto aos amigos em jantares, viagens ou qualquer evento propício para isso. Com cinco anos, Felipe, meu irmão, começou a tocar um pouco do violão que meu pai ensinou a ele. Com três anos, eu tentava acompanhar cantando. Em 1987, no meu aniversário de sete anos, cansada dos discos da Xuxa e do Balão Mágico, pedi a meu pai "Vida bandida", o álbum do Lobão. Não sei se tinha a ver com a história da Chapeuzinho Vermetho, mas eu adorava o nome do cara. Não lembro onde nem como, mas eu tinha escutado falar que o lobo grande era roqueiro. Associei de alguma forma ao meu estilo de vida: se meu pai era roqueiro e essa música chamada rock era a que eu estava acostumada a ouvir em casa, parecia-me óbvia a ideia de que eu ia amar aquele tal Lobão. Foi uma felicidade inenarrável ganhar aquela bolacha de vinil com capa escura no meio da minha festa de aniversário, cujo tema era "Rock". No topo do bolo, uma Barbie roqueira portando uma guitarra mostrava que quem apagaria a velhinha não estava de brincadeira.

Na medida em que fui crescendo, vi o rock perdendo um pouco sua força para o sertanejo, o pagode, o funk e o axé - no início da década de 1990 - e fui absorvendo novas influências. Nem tudo eu aceito e muitas coisas eu digo que não aceito para não decepcionar meu pai ou meu irmão, hoje um roqueiro fiel à guitarra e à bateria. Os dois têm juntos uma banda, que formaram quando eu tinha nove anos e meu irmão, onze. Eles ensaiam aqui na sala da minha casa e eu acompanho de perto o crescimento de Felipe como músico e a satisfação do meu pai com a resposta que o filho lhe dá. Talvez por já ter muito trabalho com esse projeto de formar um músico autodidata, meu pai não tem muito tempo para me ensinar. Eu tento aprender violão em aulas 
particulares, mas fico sempre pra trás. Com isso, em vez de focar minha escuta em nomes específicos, como meu irmão faz, para absorver melhor as músicas, eu ouço de tudo.

$\mathrm{Na}$ época do colégio, ouvia sons variados nas festas e nas rádios. Acabei aprendendo a gostar um pouco de tudo e muito de algumas coisas. Até pouco tempo atrás, meu pai achava engraçadinho: "Coisa de menina!", ele dizia. Outro dia, cheguei a escutar ele comentando que eu corri um sério risco de me desvirtuar e virar uma pagodeira, uma funkeira ou uma amante da axé music. Sei que ele estava brincando, mas aprofundando a análise dei-me conta de que, com a bagagem que tenho e já tinha quando comecei a ouvir música além do rock, seria impossível eu me tornar alguma coisa específica. Abaixo os rótulos! Até porque, Zé Ramalho, já percebi que você não é um artista rotulável. Enquanto te escrevo, alterno na vitrola dois dos seus discos, o primeiro, lançado em 1978, e o segundo, "A peleja do diabo com o dono do céu", e percebo que sua música é um hibrido de muitas influências. Talvez isso é que tenha feito com que eu me identificasse com ela. Olha que loucura! Escrevi sobre Hélio Oiticica na carta anterior a esta e acabo de encontrá-lo nas fotos da capa e do encarte do álbum de 1980, feitas pelo hoje cineasta Ivan Cardoso. Olha só, é ele mesmo! E está ao lado de um Zé do Caixão fantasiado de demônio, que simula uma peleja contra Deus, no caso você vestido de branco. Essa ideia de encenar a peleja é algo tão nordestino... Lembra os folhetos de literatura de cordel que compro quando visito a Academia Brasileira de Literatura de Cordel, no bairro de Santa Teresa. Você já esteve lá?

Quero conhecer melhor a cultura nordestina! E você. Apesar de agora saber sua cara pelas fotos desses álbuns, ainda não sei sobre sua trajetória... Sem a ajuda do meu pai, como farei para descobrir? Pela primeira vez, não identifiquei nele uma sintonia com meu gosto musical, mas isso não vai fazer com que eu abandone a ideia de conhecer melhor os artistas que me cativam. Muito menos você, que me instiga (ou será intriga?) mais do que todos os outros nesse momento.

Assinado: Christininha 


\section{0 dia em que vaticinei que escreveria a biografia}

Reli diversas revistas, busquei nos recortes de jornal que meu pai guardava e no meus, vasculhei as estantes de livros e não achei nada demais sobre o tal Zé Ramalho. "Nome tão comum", pensei. E agora, como vou entender o que ele quis dizer com aquelas frases tão psicodélicas? Não existia Google ou qualquer outro site de pesquisa naquela época. No Brasil, a internet ainda era usada para envio de dados e beneficiava poucos usuários. Contenteime com as poucas informações que coletei com amigos músicos e jornalistas e vaticinei: "Se ninguém escrever a biografia de Zé Ramalho, eu o farei!" Acho que só de escrever diários, eu já sabia que "la escritura es el modo en que se experimenta lo íntimo de cada vivencia, la íntima distancia con uno mismo en el acto de amar, de cocinar respetando la vida de la materia o de vestir la 'desnudez sustancial' del proprio cuerpo." (GIORDANO, 2006, p. 60) E, nos dois anos que se seguiram depois daquele meu primeiro encontro com a voz de Zé Ramalho, tratei de comprar todos os discos dele que achei. E, finalmente, encontrei um livro que enriqueceu minha pesquisa: Jorge Salomão, escritor e irmão do poeta Waly Salomão, transcreveu um depoimento de Zé para a introdução de um songbook com 30 canções lançado pela editora Gryphus. Nele, descobri que Zé nasceu em Brejo do Cruz, cidade do interior da Paraíba, e que morou na capital, João Pessoa, mas que encontrou Alceu Valença e Geraldo Azevedo em Recife e de lá saiu para tentar a sorte no Rio de Janeiro. Também descobri que Elba Ramalho gravou composições do primo em diversos momentos de sua carreira. Neste 1999, assisti a Zé Ramalho pela primeira vez, em uma de suas apresentações, que já naquela época era como qualquer show de sucessos. Consegui a palheta que Zé usou no palco e, com ela, a senha para entrar em seu camarim e fazer uma foto ao seu lado. Aproveitei para reclamar do pouco material de pesquisa disponível sobre ele. Eu ainda não acreditava que podia ser a responsável pela biografia autorizada sobre a vida e a obra daquele 
músico que levantava multidões, conforme eu tinha verificado no ATL Hall no Metropolitan².

Niterói, 15 de dezembro de 1999.

Caro Zé,

Estou de férias da faculdade, mas não do trabalho. Em agosto, meu pai me convocou para passar minhas tardes em seu escritório ajudando-o em sua organização e ocupando o tempo liure que ele e minha mãe achavam que eu estava dedicando "demais" a meu namorado. Virei secretária e passei a ter pouco tempo para o que eu realmente estava fazendo antes de eles imaginarem coisas: ouvir meus discos, ler meus livros e investir em minhas pesquisas. Tampouco tenho conseguido escrever no meu diário. A parte boa é que, em contrapartida, meu pai passou para mim a coluna que ele assinava numa revista daqui de Niterói chamada $O$ Cais. Agora, todo mês eu escrevo um artigo sobre algum artista ou banda. E assino Christininha Fuscaldo. Eu queria assinar Christina Melo, mas meu pai sugeriu que eu usasse o sobrenome da minha mãe, pois Melo é muito comum. Tentei Christina Fuscaldo Melo, mas ficou grande demais. Aí, mandei Christina Fuscaldo para o editor e ele colocou Christininha já no primeiro número. Ficou assim.

Um dia quero escrever sobre Zé Ramalho. Não agora, porque ainda sei muito pouco sobre você. Isso também anda me ocupando muito. Por sorte, no primeiro semestre, mergulhei a fundo nos seus álbuns que adquiri e no songbook e aprendi a tocar umas canções suas no violão. De ouvir, as harmonias parecem dificilimas, mas descobri que elas não são. A sofisticação está nos arranjos - que, pelos créditos do seus dois primeiros disco, são seus e de Paulo Machado - e eu posso dizer isso com propriedade, porque toco mal. Não sei fazer pestana, então, esbaldo-me inaugurada em 1994, teve seu nome mudado para ATL Hall em 2000 e, em 2003, para Claro Hall. Desde 2007, é chamada de Citibank Hall. 
em sequências com Ré, Sol e Lá, como é a que inicia "Avôhai". Sobre o depoimento que deu a Jorge, fiquei impressionada ao tentar relacionar o que li com o que escuto. Estou cada vez mais curiosa sobre suas experiências e com a Paraíba. Difícil vai ser ir a Brejo do Cruz, onde você nasceu. Não achei essa cidade em nenhum mapa! Campina Grande, onde passou parte da infância e da adolescência, é mais familiar. É lá que tem uma festa de São João muito famosa, não é?

Gostei de saber seu nome todo: José Ramalho Neto. Meu pai também tem Neto no sobrenome. Não te contei ainda, mas atendo por três nomes. Logo que nasci, minha madrinha de consagração sugeriu que minha mãe desse a mim o nome delas: Cristina (minha mãe é Cristina Maria e minha madrinha, Maria Cristina). Mamãe incluiu um H virei Christina Fuscaldo de Souza Melo na certidão de nascimento, Christininha para os familiares e amigos de infância e, recentemente, Chris para os colegas da faculdade de Jornalismo, carreira que escolhi seguir paralelamente aos estudos de Letras: acabei de prestar vestibular novamente e vou estudar Italiano. Desde que ganhei a cidadania do meu bisavô, venho pensando em aprender a língua dele. Já sei também que você é libriano. Eu sou virginiana, com ascendente em Touro e Lua em Gêmeos: organizada, responsável, perfeccionista e justiceira, além de emotiva, generosa e afetuosa. Simpático, sei que és. Adorei a maneira como recebeu a mim e a meu namorado no Metropolitan. Marcelo que pegou a palheta para mim. Ele convenceu o segurança de que éramos parentes seus para irmos ao camarim. A parte triste foi perder a foto que tiramos juntos. Eu usei a câmera fotográfica da faculdade e o filme estava perto do fim. Fazendo o processo de revelação manual, ao retirar o negativo da química, as duas últimas imagens foram prejudicadas pelo tempo de exposição da película. Agora, estou na expectativa de encontrá-lo para poder fazer um novo registro.

Beijos,

Christininha 


\section{Um primeiro artigo... raso}

Durante os quatro anos em que me dediquei aos estudos das mídias na faculdade e à função de estagiária, soube através das assessoras de imprensa que trabalharam com Zé Ramalho que o cantor não gostava de dar entrevistas. Entendi a dificuldade que eu estava tendo de encontrar referências a ele. Já acostumada a desbravar o universo particular dos músicos que entrevistava, preocupei-me em relação ao meu projeto secreto de escrever a sua biografia, afinal, como eu ia aproximar um ídolo dos seus fãs sem obter declarações dele? Para a escritora e professora argentina Leonor Arfuch, "desde seu surgimento, como maneira de resguardar e autenticar palavras ditas na imprensa, a entrevista se revelou como um meio inestimável para o conhecimento das pessoas, personalidades e histórias de vidas ilustres e comuns" (ARFUCH, 2010, p.151). Descobrir mais sobre a história de Zé Ramalho não seria tarefa fácil. Foi isso que pensei logo que me propus a fazer um texto para O $\mathrm{Cais}^{3}$, revista que era distribuída apenas na Região Oceânica de Niterói, onde morei até o fim dos meus estudos. Em 2000, escrevi sobre a vida e a obra de Zé com o pouco que sabia um artigo, que hoje acho raso. E aproveitei para recortá-lo da revista e colá-lo no caderno em que eu dialogava com meu amigo imaginário da Paraíba.

3 FUSCALDO, Christina. Vocês que fazem parte dessa massa... O Cais, edição 100, anos XI, no 100, p. 14, jun. 2000. 
Niterói, 15 de junho de 2000.

\section{Oi, Zé! Tudo bem?}

Lembra que te falei sobre a revista para a qual comecei a escrever? Publiquei este mês um artigo sobre você. Enquanto eu escrevia, fui me dando conta do quão pouco eu sabia sobre sua vida e até sobre sua obra. Usei o pouco que achei na internet como base. Não sou uma crítica de música ainda, apesar de ouvir muito sobre essa função do Jornalismo com o primo do meu pai, o jornalista Luiz Antonio Mello (aquele que fundou a Rádio Fluminense FM nos anos 1980), e com meus chefes da Rádio JB FM, que não trabalham com música, mas estão há anos no mercado. Não te contei ainda que troquei o emprego no escritório do meu pai por uma vaga como estagiária na rádio. Estou super feliz e animada. E, agora, além da revista, escrevo também para o portal de um amigo niteroiense chamado Itacoatiara.com. Os destaques do site são as fotos da praia e as previsões do tempo e do mar, mas há espaço para outros assuntos e eu ganhei uma coluna com meu nome (ou melhor, apelido): Coluna da Chris. Lá, eu publico entrevistas e resenhas de shows que acontecem em Niterói. Em O Cais, sigo a linha que meu pai lançou de apresentar ao leitor um artista através de informações sobre sua vida e obra. Foi o que tentei fazer com você, mas olha só como faltaram dados... Não repare os rabiscos! Foi meu pai que pintou a página enquanto revisava meu texto e me mostrava o que achava que poderia ter sido escrito ou diagramado melhor. Colo o texto aqui para que possa ler no dia em que eu conseguir te entregar esse caderninho.

Um beijo,

Christininha Fuscaldo 


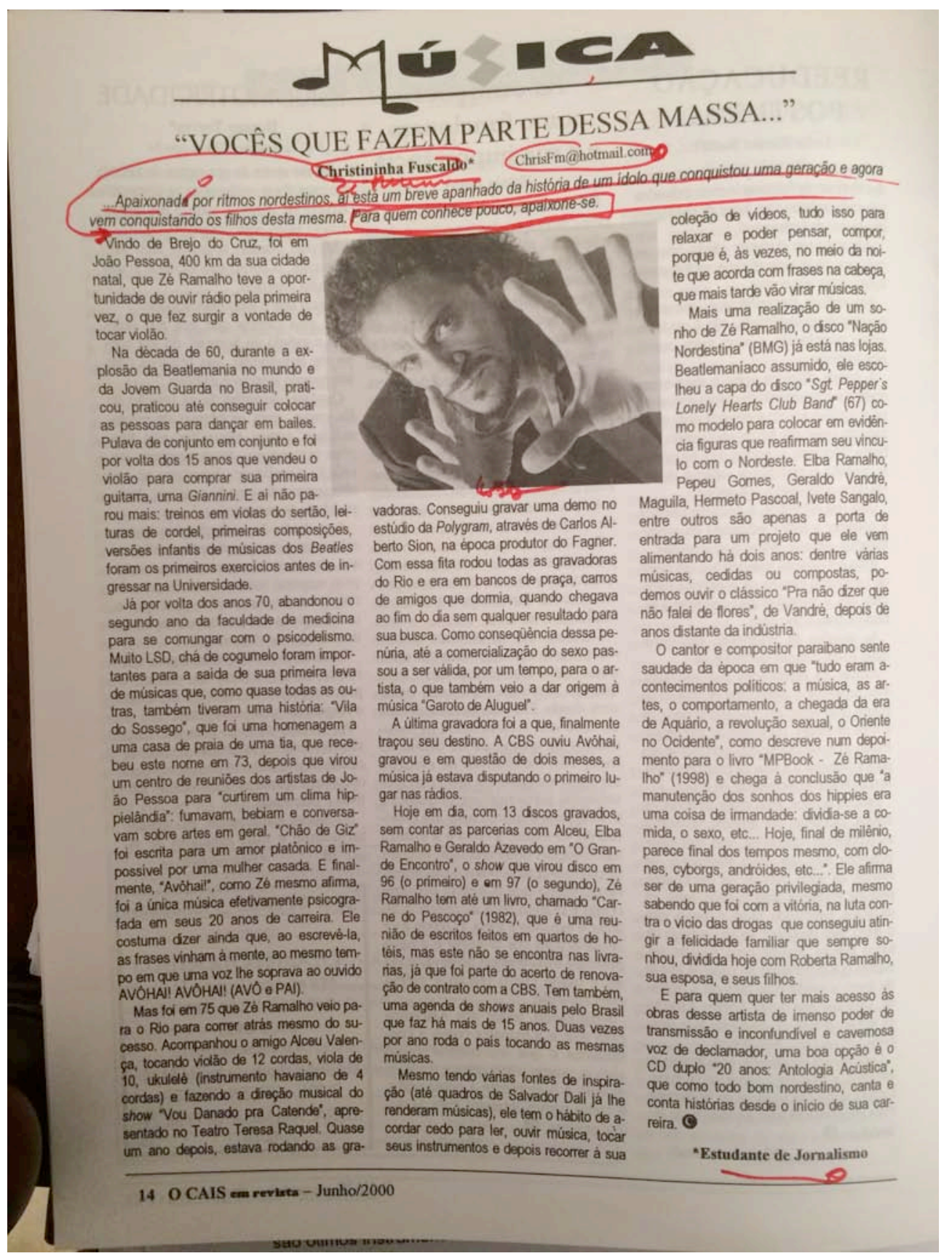




\section{Os primeiros recortes para meu arquivo}

Meu último trabalho como estagiária foi entre outubro de 2001 e março de 2003, primeiro no recém-lançado portal de notícias GloboNews.com e, no final, no site O Globo Online, que trazia trechos das publicações do jornal O Globo e matérias produzidas pela equipe de internet. Em ambos, fui pupila de um dos maiores críticos de música do Brasil, Jamari França, de quem eu já era fã desde quando escolhi estudar Comunicação Social. Comecei a ler as matérias e críticas de Jamari quando ele trabalhava no Jornal do Brasil. Para mim, depois de Ana Maria Bahiana, jornalista de música atuante nos principais veículos culturais das décadas de 1970 e 1980 (a quem me comparavam meu namorado e nosso amigo Leandro Souto Maior, que depois veio a ser meu parceiro de profissão e de banda), Jamari era o melhor. Ambos eram roqueiros e eu percebia neles referências muito parecidas com as minhas, as que aprendi com meu pai. Quando me apaixonei por MPB, já mais madura um pouquinho, abri espaço para críticos especializados em diversos estilos entrarem na minha vida, entre eles Mauro Ferreira, Tárik de Souza e Antônio Carlos Miguel.

Na época do meu estágio na JB FM, eu via Jamari quase todo dia, na hora do almoço. O Jornal do Brasil ficava no terceiro andar do prédio da Avenida Brasil enquanto a rádio ocupava o mesmo andar do refeitório. Fiquei triste quando soube que ele foi demitido da empresa, que já estava em vias de ir à falência. Estava muito feliz com meu grupo de amigos, com as rodas de violão que fazíamos em um dos estúdios na hora da sesta, com os shows de música brasileira que a rádio promovia semanalmente e com os encontros inusitados com os artistas internacionais que eventualmente passavam por lá. Uma vez, meu coração disparou quando vi atravessar o corredor do elevador até um dos estúdios da rádio Cidade (parceira da JB FM) um dos irmãos britânicos da banda Oasis: no dia seguinte de se apresentar na terceira edição do Rock in Rio, em 2001, Noel Gallagher foi convidado a dar uma entrevista e uma palhinha ao vivo. 
Meu melhor amigo da rádio, Vitor era programador e me avisou logo cedo que o músico iria nos visitar. Eu não acreditei. Quando Noel chegou, super antipático com seus óculos escuros redondos, fiquei paralisada. E passei dias comentando com todos o que tinha acontecido. Mas eu sentia falta de liberdade para expor minha criatividade, coisa que só estava fazendo em O Cais e no Itacoatiara.com: na rádio, minha função era resumir matérias, transformando-as em notas de menos de 300 caracteres. Pedi a meus chefes, Antonio e Carlos - que não eram os irmãos Gallagher, mas sim os Couto Ribeiro - para sair. Um mês depois, Antonio, um beatlemaníaco que debatia música comigo o tempo todo quando trabalhávamos no mesmo horário, indicou-me para uma vaga no GloboNews.com, um dos primeiros sites de notícias do Brasil, onde ele trabalhava pela manhã. Ao sair da entrevista com a chefe de Antonio e minha futura chefe, Valéria Rheder, esbarrei com o meu crítico de rock favorito: ele estava de pé, na porta da redação. Não me contive e exclamei seu nome: "Jamari França!" Surpreso, ele respondeu: "Sou eu!" Sem saber o que falar, deixei escapar: "Sou sua fã!" E segui caminhando, morrendo de vergonha, sem olhar para trás. Menos de seis meses depois de ter sido contratada para a vaga de estágio, ele sugeriu ao então editor de Cultura, João Ximenes Braga, que me tirasse da função de produtora de notas de 160 caracteres para SMS $^{4}$ e me levasse para sua equipe, na época carente de especialistas em música.

Jamari era crítico e sua especialidade sempre foi o rock. Com a velocidade e a demanda desenfreada por quantidade (mais do que por qualidade) que a internet estava impondo aos jornalistas, causando uma reviravolta nos moldes de trabalho de toda uma geração, ele estava sendo obrigado a escrever sobre todo tipo de música e sem muito tempo para fazê-lo bem. Eu cheguei para socorrê-lo e, ao mesmo tempo, sugar dele o conhecimento que não tinha adquirido na faculdade até aquele quarto semestre. Aprendi muito sobre música, sobre como escrever sobre música e sobre como pesquisar para matérias jornalísticas de música nos quase dois anos que passei lá e, também, no 0 Globo Online, que a três meses da minha formatura absorveu a equipe que

4 Do inglês Short Message Service, o serviço de mensagens curtas, conhecido como mensagem de texto, permite o envio de mensagens curtas a telefones celulares. No início dos anos 2000, equipes foram montadas dentro das redações para a venda de conteúdo jornalístico para empresas de telefonia móvel. 
sobrou após a demissão em massa ocorrida em função do fim do GloboNews.com. João, nosso chefe, saiu - o que me fez chorar um dia inteiro e Jamari, meu chefe indireto, ficou - o que me fez comemorar. Para além de tudo o que ele me ensinou, aprendi também vasculhando o setor de pesquisa do jornal, a biblioteca da universidade e as livrarias, sempre em busca de livros de outros autores sobre outros artistas ou movimentos musicais que podiam ter relação com aquele que eu buscava. Finalmente, encontrei diversas publicações sobre Zé Ramalho. Fotocopiei todas elas e comecei a montar mais um dos meus arquivos, este sobre o meu futuro biografado.

Não, a estrutura técnica do arquivo arquivante determina também a estrutura do conteúdo arquivável em seu próprio surgimento e em sua relação com o futuro. $\mathrm{O}$ arquivamento tanto produz quanto registra o evento. É também nossa experiência política dos meios chamados de informação. (DERRIDA, 2001, p. 29)

Entendi também que entrevistar muitos e diversos personagens que tiveram algum tipo de vivência durante o período e na cena que me interessavam faria a maior diferença. Só que isso eu não conseguiria naquele momento de trabalho intenso. Foi aí que decidi escrever mais uma carta para Zé Ramalho, listando as perguntas que eu gostaria de fazer a partir do que eu já tinha lido. Imaginei que, assim, já teria uma pauta pronta para o dia em que surgisse a oportunidade de entrevistá-lo ou a algum de seus parceiros.

Niterói, 03 de outubro de 2002.

$$
\text { Oi, Zé! }
$$

Agora já sei um pouco mais sobre você. Não tanto quanto eu gostaria. Mas sei que hoje é o dia do seu aniversário. Parabéns! Muitas felicidades! Mas não foi para isso que resolvi te escrever. Ainda não te falei nada, mas tenho segundas intenções. Passei uma temporada sem dar 
notícias porque, desde que comecei a trabalhar, fiquei ocupada demais. Agora, além de ter conseguido sua discografia completa, estou cheia de recortes de jornal, links da internet - que maravilha de advento! - e experiências contadas a mim por jornalistas que conheci nas entrevistas coletivas e eventos que cobri como estagiária do GloboNews.com. Quais são minhas intenções? Quero escrever sua biografia. Sei que, quando ler essa carta, vai achar isso um absurdo. Talvez, agora, seja mesmo. Nem formada sou ainda... Mas falta muito pouco. E, olha, estou adquirindo uma grande experiência no processo de produção da minha monografia. É sobre Os Mutantes, minha banda brasileira favorita. Ando lendo muito e fazendo diversas entrevistas. Até Rita Lee, que sempre admirei muito, topou falar comigo! Pois é... Ela agora cismou que só dá entrevista por email, mas por mim tudo bem. Acho até melhor. Primeiro porque ela tem uma escrita fluida, não abre mão das piadas e responde rápido. Depois, porque as mensagens ficam registradas na minha caixa de entrada ou na pasta onde compilo todo o material que estou coletando, inclusive as impressões das mensagens que troco com todos os personagens do meu trabalho. $\dot{E}$ preciso arquivar, $Z \dot{e}$, porque tudo isso é prova de que essas pessoas falaram comigo e do que elas contaram a mim.

Também ando trocando muita ideia - e até fiz uma visita a ele em São Paulo - com Sérgio Dias. Lembrei de você quando falamos da Guitarra de Ouro que ele usava na época de Os Mutantes. Você acredita que ele não lembra se foi com ela que gravou "A dança das borboletas" em seu primeiro disco? Aliás, eu adoraria saber se você era tão fã dos Mutantes quanto eu sou. Enfim, voltando à sua biografia, daqui a dois meses, eu termino a faculdade de Jornalismo e retomo a de Letras, que comecei em 2000, mas tranquei porque não dei conta de cursar duas universidades e trabalhar. É por isso - e por achar que não estou preparada - que não te enviarei essa carta por enquanto. Mas anotarei as primeiras perguntas que gostaria de fazer depois que conseguir te convencer de que você precisa contar a sua história.

1 - Você saiu de Brejo do Cruz ainda muito novo, acho que com dois anos, e foi levado a Recife por sua mãe depois da separação de seus pais, mas acabou voltando para a Paraíba após 
um acordo entre eles, só que para Teixeira, onde ficou até pouco depois de completar quatro. Você acha que a breve vivência no sertão pode ter afetado você ou sua música de alguma forma?

2 - Seu pai morreu afogado no açude do sítio de Teixeira quando você tinha três anos. Alguma recordação ficou desse homem? Qual o maior legado você acredita que ele tenha deixado? Será que foi dele, que era seresteiro, que você herdou o talento para a música?

3 - Sua mãe ficou morando em Recife com sua irmã e você, na Paraíba com seu avós e tias. Como foi sua criação?

4 - Por que não encontrei nenhuma menção sua à avó ou à mãe nas entrevistas que deu a jornalistas? Por que a figura masculina me parece mais forte que a feminina na sua familia? 5 - Como surgiu a vontade de vir para o Rio e o que fez para conseguir chegar aqui?

6 - É verdade que, pouco depois de chegar ao Rio para tentar a sorte e antes de gravar seu primeiro disco, você morou na rua e trabalhou como garoto de programa?

7 - Eu gostaria de saber mais sobre sua amizade com Alceu Valença e com Geraldo Azevedo, pois li em alguma matéria que você tocou com Alceu e compôs com Geraldo antes de assinar seu primeiro contrato com uma gravadora. Outra curiosidade que tenho é sobre o seu parentesco com Elba Ramalho: ela é mesmo sua prima?

8 - Ao mesmo tempo em que acho "Chão de Giz" uma canção romântica, não entendo muitas das frases que canta. Quando a compôs, você quis passar algum recado através da letra?

9 - Você se sente mais cantor ou mais compositor?

10 - Ouvi dos meus colegas que você não é muito amigo dos jornalistas. Por que você não gosta de dar entrevistas?

Um beijo,

Chris 


\section{A primeira entrevista a gente nunca esquece}

Apesar de a pauta estar pronta, fui sem ela para o encontro de Jamari França com Zé Ramalho. Em março de 2003, meu tutor - que não tinha minha companhia na redação desde que colei grau, no início do mês - ligou-me e convidou-me a acompanhá-lo em uma entrevista que faria com o paraibano a respeito do álbum que estava lançando, o "Estação Brasil". Eu tinha acabado de pegar meu diploma e havia sido dispensada do programa de estágio da Globo.com ${ }^{5}$. Reabri a matrícula do curso de Letras e fui estudar teatro enquanto buscava formas de sobreviver como freelancer no mercado de trabalho. Jamari me deu um dos melhores presentes: "Fusca, amanhã vou entrevistar Zé Ramalho e eu queria que fosse comigo. Você sabe mais sobre ele do que eu." Eu estava triste, mas, assim como o poeta modernista Mário de Andrade disse a Manuel Bandeira em uma das cartas que enviou ao amigo pernambucano de 1922 até sua morte, "perdi o trem, perdi a vergonha, perdi a energia... Perdi tudo. Menos minha faculdade de gozar." (ANDRADE, 2001, p. 46).

Fusca foi um dos apelidos que ganhei na época do estágio. E não tinha nada a ver com minha queda pelos Beatles. Fusca era abreviação de Fuscaldinho ou Fuscaldinha, como começaram a me chamar os meus colegas na medida em que foram tomando intimidade comigo. Fusquinha e até Fusquete também funcionaram por um tempo, mas Fusca pegou de vez. Jama adorava esse apelido. E ele sabia que eu também. Sentia-me acarinhada quando alguém me chamava assim. Ao me fazer o convite, meu crítico esperava só um "sim", mas acho que ele não se surpreendeu com o grito de alegria que dei do outro lado da linha. Eu fui, claro. Não sem antes recorrer ao meu arquivo e ao release ${ }^{6}$ e à cópia do encarte de "Estação Brasil", enviados a mim por Jamari cheios de

5 Empresa ligada às Organizações Globo que apostou no boom da internet e, devido a uma crise no mercado - que mostrou que os sites ainda não rendiam o lucro previsto - demitiu uma série de profissionais e não contratou nenhum dos novos que tinham em sua equipe.

6 Press release ou release é um texto informativo usados por assessorias de imprensa para informar, anunciar, esclarecer ou responder à mídia sobre um fato que envolva o assessorado. 
anotações. E não sem antes montar uma nova pauta com perguntas pertinentes ao projeto que Zé Ramalho estava lançando e ao projeto que eu estava pensando em lançar.

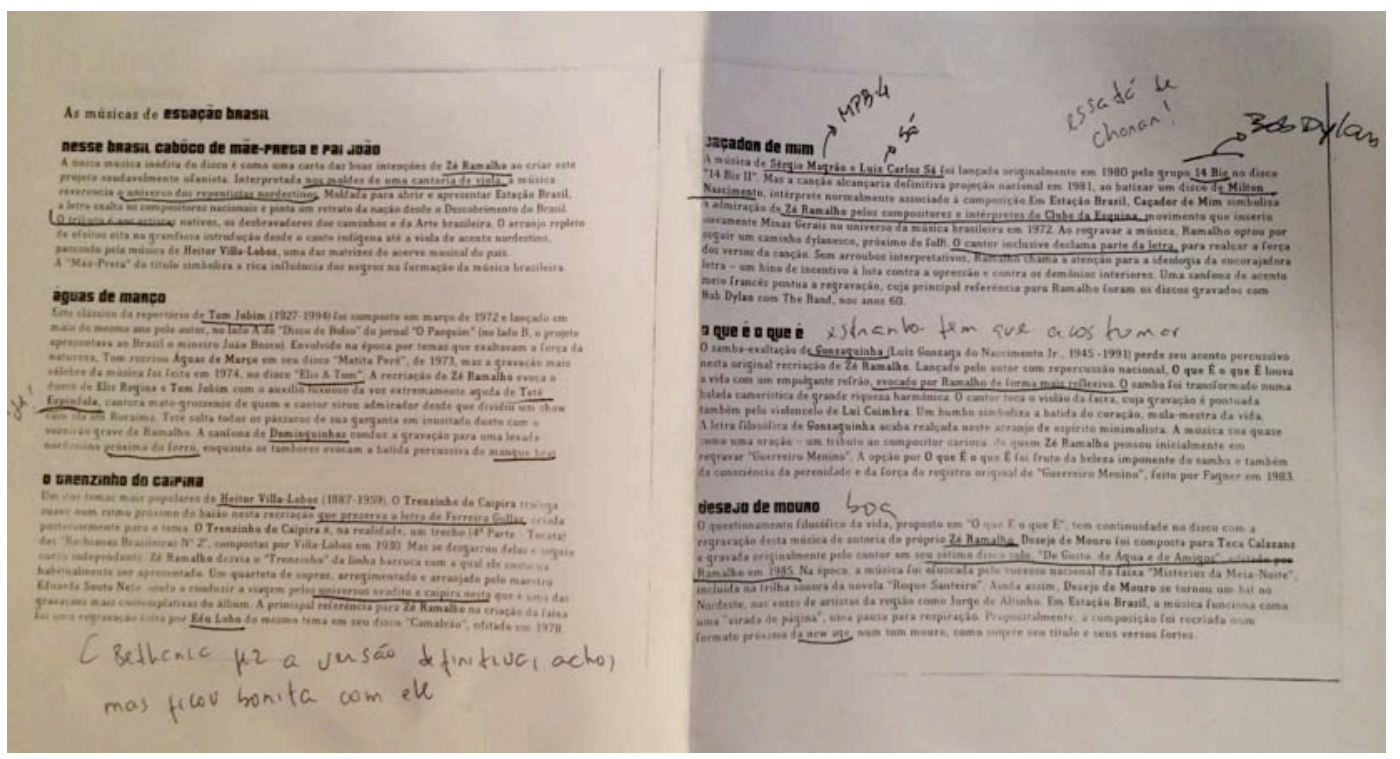

Roubei a cena, disse Jamari, depois, rindo de satisfação, afinal, eu realmente ajudei a dar ritmo ao papo. Eu e Jama dançamos conforme a música, afinal, consegui meu primeiro autógrafo do artista - na caixa com os discos lançada em 2000 que levei - e fomos convidados para o almoço na Modern Sound, a loja de discos onde a bateria de entrevistas foi marcada pela assessora de imprensa da gravadora BMG. Virginiana como eu e sensível a ponto de perceber as nossas intenções, a querida Ana Paula Romeiro só não sabia, assim como meu tutor, que minha intenção era muito mais do que apenas almoçar com Zé Ramalho.

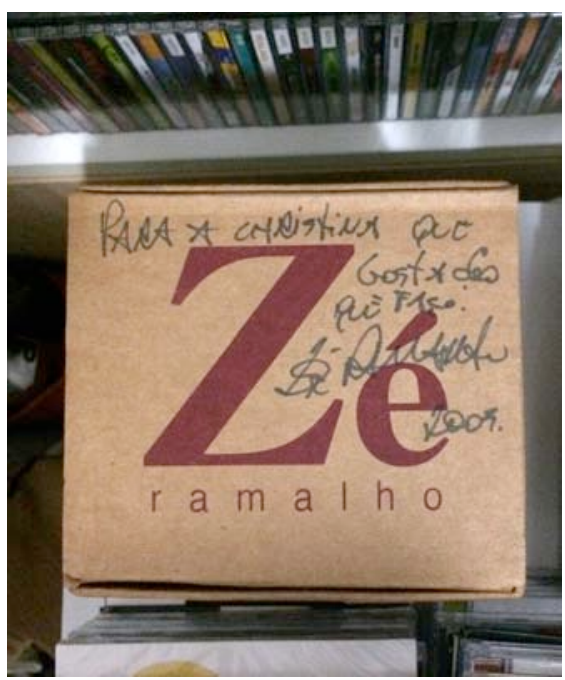


Niterói, 10 de junho de 2003.

\section{Oi, Zé! Tudo bem?}

Agora, você já me conhece. Não sei se registrou o meu nome, mas pelo menos minha fisionomia é capaz de se lembrar quando nos esbarrarmos, da próxima vez. Só não sei quando isso vai acontecer... Fui te ver no Canecão e tentei agradecer pelo espetáculo no camarim, mas você tinha ido embora. Foi a primeira vez que confirmei essa história de que, após os shows, você sempre sai correndo para casa. Acho que dei sorte naquela noite em que peguei sua palheta... Bom, escrevo porque queria comentar algumas coisas sobre as quais falamos na entrevista que fiz com você junto com Jamari. Que dia inesquecivel! Colo aqui a foło que Jama registrou de nós, sentados à mesa para o almoço, e a que Ana fez dos três logo após o papo na Modern Sound. Não sei se você reparou, mas, na saída, nossa amiga assessora me deu um pôster com a foto da capa do "Estação Brasil". Colei-o atrás da porta do meu quarto e combinou muito bem com minha decoração, que também celebra as cores da bandeira do nosso país.

Olha, não escrevo para comentar o encontro de março nem para reclamar da sua ausência no camarim. Essa minha mania de escrever mais do que o necessário me desvirtuou. Desculpe-me! Ainda bem que essa carta não vai chegar até você tão cedo. Quem sabe eu refaço o caderno, editando as cartas, no dia em que for entregá-lo a você? Quem sabe eu não digito só o que realmente for importante, imprimo e te entrego, deixando esses blá blá blás manuscritos guardados aqui comigo? Boa ideia! $E$ isso que vou fazer! Dessa forma, fico mais à vontade para escrever o que eu quiser. Não é assim que os artistas fazem quando dão entrevistas? Eles não escolhem o que vão falar para parecerem personagens mais legais? Nossa, Zé! Olha eu já com meio parágrafo escrito e sem dizer o que vim fazer hoje aqui... Ave Maria! Então, é que eu queria comentar algumas de suas músicas. Dúvidas e constatações que surgiram depois daquele encontro 
em Copacabana. Não sei se te incomoda debater sua própria obra, mas eu concordo com o que Mário de Andrade escreveu a Manuel Bandeira... Ele fala que "a melhor homenagem que se pode fazer a um artista é discutir-the as realizações, procurar penetrar nelas, e dizer francamente o que se pensa." Adoro esse jeito do poeta modernista! E ele era paulista. Depois, dizem que os cariocas é que são abusados... Eu achava que eu não era, já que sou niteroiense. Mas tudo isso que venho escrevendo tem feito eu me sentir bastante atrevida. Será que não entregar as cartas me redime?
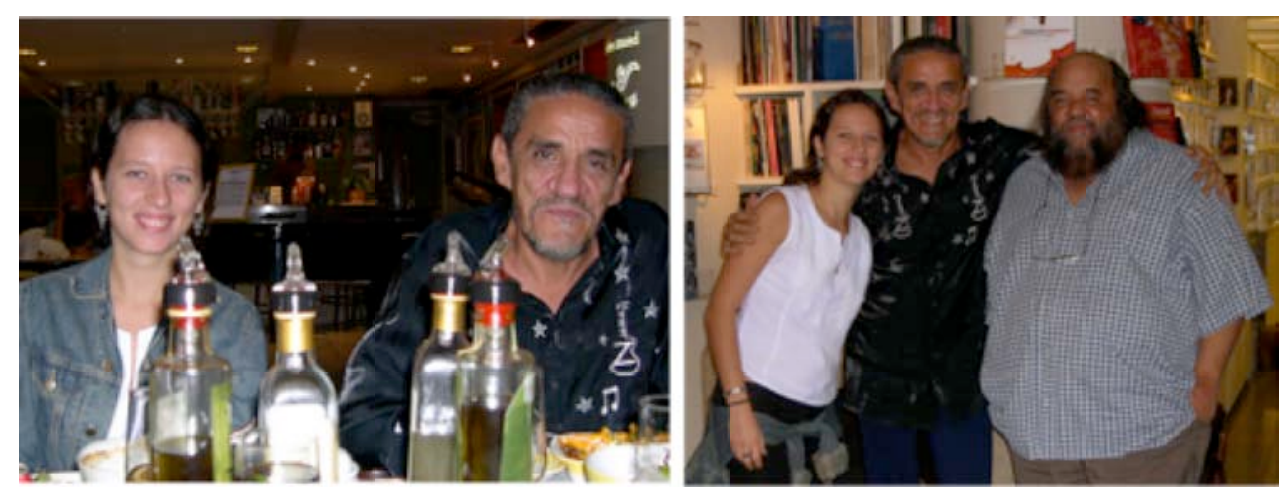

Zé, eu ouvi muito o "Estação Brasil". Gosto de algumas coisas, de outras não. Mas não convém falar das minhas preferências, afinal, não quero parecer um dos "burros", "maus" ou "infames" de que Mário fala ao comentar mais um dos episódios em que os críticos atacam o trabalho de um de seus amigos poetas. Assim como ele, eu também sofro pelos outros. Sofro quando vejo uma crítica mal feita, por isso decidi que não quero escrever sobre o trabalho de ninguém enquanto não me sentir preparada o suficiente para isso. Sendo assim, falar também do meu gosto pessoal aqui ou em uma entrevista não convém, afinal, você não pediu minha opinião. Vou escrever, então, sobre uma constatação que fiz e que me deixou feliz após ler a matéria do Pedro Alexandre Sanches na Folha de S. Paulo ${ }^{7}$, pois vi que minha percepção não destoa tanto da dele. Gosto dos textos desse cara, mesmo sabendo que ele não é da turma dos dinossauros que tanto adoro ler. Tem uns jornalistas novos que andam me inspirando muito. Pedro é um deles. Silvio

7 SANCHES, Pedro Alexandre. Zé Ramalho faz síntese de si mesmo em CD. Folha de S. Paulo, São Paulo, 7 mai. 2003, p. E4. 
Essinger e Adilson Pereira, ambos roqueiros da leva do punk e recém-saídos do Jornal do Brasil, também. Em O Globo, tem o Bernardo Araújo, adepto do rock mais pesado, e, no site do jornal, o Leonardo Lichote, que está começando, mas já anda mostrando que entende de música brasileira. Pedro sentiu a mesma coisa que eu: "O resultado é inconstante na medida em que o repertório é inconstante". Mas eu acho que as canções se adequaram perfeitamente ao seu estilo, tanto de arranjar a música e dar a ela o seu ritmo - nordestino, roqueiro e agalopado - quanto de cantá-la, abusando do estilo canto-falado que te dá ares de profeta.

O jornalista não simpatizou com "Águas de março", mas acredito que, assim como a mim, o que o incomodou nessa faixa foi a participação de Tetê Espíndola. Aquela voz agudíssima tinha tudo a ver com "Escrito nas estrelas" - canção com a qual ela venceu o Festival dos Festivais da TV Globo, em 1985 -, mas fez o clássico de Tom Jobim desandar no seu disco, Zé. Jamari chorou com "Caçador de mim". Eu chorei ao ouvir "Romaria", canção de Renato Teixeira que ficou linda com você e Fagner representando o sertão de verdade. Apesar de gostar muito do estilo, sempre questionei essa coisa de a música dele e de Sérgio Reis ser rotulada como sertaneja, afinal, os dois são de São Paulo. Renato é de Santos, litoral paulista. Sérgio começou a carreira cantando rock no embalo da Jovem Guarda. Na verdade, eles sempre defenderam a chamada "música caipira". Se formos levar ao pé da letra, sertanejo mesmo é você e Fagner, que nasceram em Brejo do Cruz e em Orós, sertões da Paraiba e do Ceará, respectivamente. Por isso achei muito significativo você trazer essa canção para seu repertório. "Estação Brasil" reúne canções que mostram sua relação com a música brasileira em geral e segue o mesmo formato do "Nação nordestina", em que homenageia a cena da sua região, e do "Antologia acústica", uma celebração de sua própria obra. Gosto dessa ideia de dividir tudo o que vem mexendo com você ao longos dos últimos 20 e poucos anos de carreira em três grandiosos projetos.

Gostaria de aproveitar o momento para falar sobre o "Antologia acústica". Esse era o CD que meu pai tinha em casa junto com os vinis de que falei. Na época, ouvi os dois discos, mas não li o libreto que acompanha o encarte porque estava perdido pelo armário dele. Ao perceber a 
importância dos textos de Mauro Ferreira para o meu entendimento sobre a escolha do repertório de "Estação Brasil", ao voltar da entrevista, vasculhei a casa atrás do encarte antológico: com textos de Zuza Homem de Mello, ali estariam explicações sobre algumas de suas canções mais famosas. Lançado em 1997, "Antologia acústica” foi o projeto que consolidou seu nome como um dos maiores da música brasileira, alçando-te à fama pela segunda vez. Eu adoro folhear o encarte e ver as xilogravuras de Ciro Fernandes, o paraibano que fez as imagens que ilustram o cordel "Apocalypse", escrito por você em 1977 e lançado junto a seu primeiro disco, em 1978. Aliás, foi ele também quem talhou o seu nome para a capa do álbum de estreia, não foi? Genial essa ideia de homenagear a literatura da sua terra em seus primeiros trabalhos. Genial esse reencontro agora!

Após ler as considerações sobre "Beira-Mar", fiquei curiosa sobre sua relação com a literatura de Portugal. Porque, para compor essa canção, você se baseou em "Os Lusíadas", no qual Luís Vaz de Camões narra o caminho marítimo para a Índia por Vasco da Gama. Assim como o autor fez no século XVI, você escreveu estrofes com tamanho e métricas fixas. Só que ele escreveu dez cantos, 1102 estrofes, que são oitavas decassilabas, e você criou um canto de três estrofes décimas hendecassilabas, ou seja, com dez versos de onze silabas. No ritmo tanto melódico quanto harmônico, você se utiliza do galope-à-beira-mar, que na literatura de cordel significa fazer estrofes de dez versos com onze silabas e é um formato de repente derivado do martelo agalopado (estrofes de dez versos e dez silabas), que por sua vez é uma modalidade variante do decassilabo heroico usado por Camões. A mistura da literatura popular com a música transformou "Beira-Mar" em uma "canção agalopada", o tal ritmo que você diz que criou le deve ser verdade porque não conheço nenhum outro músico que o utiliza). Foi na escola que você leu essa obra poética de Camões fundamental para a cultura portuguesa? Ou foi depois de mais velho, quando saiu viajando pelo interior da Paraíba? Algum dos cantadores que encontrou pelo caminho te falou da relação da literatura de cordel com a epopeia do português e com outras obras lusitanas? Pergunto isso porque eu só fui ter contato com "Os Lusíadas" na faculdade de Letras, nas aulas de literatura portuguesa. $E$, olha, já que Mário confessou a Manuel, vou te falar a 
verdade também: como ele, eu nunca os li "inteirinhos". Vou repetir a frase do modernista porque é exatamente o que acontece comigo: "Me cansa, fica pro dia seguinte e não pego mais."

Também acho interessante como você absorveu a questão da musicalidade no cordel. Você sabia que, quando Eduardo Galeano convidou J. Borges para ilustrar um livro, ele percebeu que o xilogravurista pernambucano não respondia suas perguntas e propostas porque sua fala, em outra lingua, não tinha melodia? "Mis palauras no tienen musica", ele pensou. E, em vez de falar de negócios, o escritor começou a contar seus contos para Borges ${ }^{8}$, que finalmente compreendeu o que o uruguaio queria. Eu soube, através das pesquisas que fiz na Academia Brasileira de Literatura de Cordel, que essa literatura surgiu no Renascimento, quando se iniciou a impressão de relatos orais feitos pelos trovadores medievais, e que os folhetos eram comercializados pendurados em cordões. Depois, vieram de Portugal para o Brasil, chegando primeiro na Bahia, e viraram fenômeno no Nordeste na segunda metade do século XIX. Se na Europa renascentista o cordel informava o povo das histórias correntes, no Brasil, além desse papel de comunicadora, essa literatura também reunia contos heroicos, sempre tendo uma problemática a ser resolvida, porém utilizando-se textos bem-humorados. A literatura de cordel aparece como um meio híbrido em que vocalidade e escritura se fundem devido à presença de elementos como o ritmo, a musicalidade, a estrutura de rimas e o vocabulário próximo ao linguajar corrente. E o cordel está presente na melodia e na estrutura de muitas outras canções suas, Zé. Por exemplo, uma que está no "Antologia acústica" e e do álbum "A terceira lâmina", de 1981, "Canção agalopada" apresentou como ponto central uma problemática a ser resolvida através da inteligência e da astúcia, característica típica dessa literatura. Parece você assumiu esse papel de trovador e começou a narrar suas histórias ou outras que queria contar. É o caso também de "Mulher nova, bonita $e$

8 As xilogravuras ilustram o livro de contos "Las palabras andantes", de Eduardo Galeano.

9 A canção reúne três estrofes de dez versos e métrica que varia entre decassílabos e hendecassílabos. Como é possível ver nos versos da canção: "Pode ser que ninguém me compreenda / Quando digo que sou visionário / Pode a bíblia ser um dicionário / Pode tudo ser uma refazenda / Mas a mente talvez não me atenda / Se eu quiser novamente retornar / Para o mundo de leis me obrigar / A lutar pelo erro do engano / Eu prefiro um galope soberano / À loucura do mundo me entregar." 
carinhosa faz o homem gemer sem sentir dor", que também ganhou versão acústica, mas foi gravada originalmente por Amelinha em 1982, época em que vocês ainda estavam casados. Esse cordel foi escrito pelo cantador e repentista Otacilio Batista, que te deu autorização para criar uma melodia para seu texto. Acho linda essa canção e adoraria saber como as melodias surgem para você quando se sente atraído por uma letra ou uma rima.

Zé, você já leu o único cordel que o poeta mineiro Carlos Drummond de Andrade escreveu, em 1980? Chama-se "Estória de João - Joana" e foi inspirado em uma notícia de jornal. Ele definiu a literatura como uma "uma das manifestações mais puras do espírito inventivo, do senso de humor e da capacidade crítica do povo brasileiro, em suas camadas modestas do interior." Eu adoro quando ele comenta que a "espontaneidade e graça dessas criações fazem com que o leitor urbano, mais sofisticado, thes dedique interesse, despertando ainda a pesquisa e análise de eruditos universitários." Sabe por que gosto disso? Porque me parece que Drummond estava afinado com as ideias de Rancière, aquele que escreveu sobre a partilha do sensivel, que, por sua vez, parece que pensou em você quando escolheu esse tema. A massa brasileira, formada por "eruditos" ou "camadas mais modestas", teve acesso ao cordel por causa de pessoas como você, não só através de sua música como também do "Apocalypse”. Genial também você ter aproveitado trechos do livro em "Beira-Mar"!

Nossa, essa carta ficou grande demais. Vou parar por aqui.

Um beijo,

Fusca

P.S.: Lá no Globo Online, deram pra me chamar de "Fusca". Acho divertido, assim como gosto de "Zé Ramalho da Paraíba" e de "Zeh", as duas variações do seu nome que encontrei em recortes de jornais antigos. 


\section{A minha primeira entrevista que nunca vou esquecer}

Algum tempo se passou entre 2003 e 2005, ano em que voltei à Infoglobo, que abarcava os jornais das Organizações Globo (O Globo e Extra) e o site do jornal O Globo. O prédio ficava no Centro do Rio, enquanto a Globo.com tinha se fixado de vez na Barra da Tijuca. Depois de dois anos na luta por um emprego, alternando estudos com colaborações para revistas e assessorias de imprensa, fui convidada a assumir o posto de produtora de conteúdo para o site do Big Brother Brasil 5. Dois meses depois, fui tirada de lá por um dos editores executivos do Extra. Quem me apresentou a ele foi minha amiga Hérica Marmo, editora de Cultura do mesmo veículo, que me alugou um quarto em seu apartamento no Flamengo quando começou minha jornada no reality show da TV Globo, pois ficou inviável morar na Região Oceânica de Niterói e trabalhar no Projac $^{10}$. Luiz André Alzer viu em mim uma profissional pronta para ocupar um espaço que estava vazio desde que o jornalista de música (e, por coincidência, meu namorado entre 2003 e 2004 e de 2005 a 2010) Adilson Pereira havia saído de lá, cinco anos antes: depois de quase dois atuando como jornalista autônoma em um mercado onde eu era pouco conhecida, fui chamada para ocupar a vaga de repórter e colunista de música no jornal popular. Um ano antes, eu tinha começado a colaborar para a Revista da MTV, cuja redação ficava em São Paulo, e tinha escrito meu primeiro release para uma gravadora. Para a MTV, publiquei entrevistas fantásticas, como uma com Jorge Mautner e a do Erasmo Carlos. No Extra, comecei a escrever sobre artistas e bandas mais populares, gente do samba e do funk, e meu primeiro êxito foi uma capa da revista Canal Extra com Latino bem na época em que ele explodiu - ou melhor, reapareceu na mídia - com a música "Festa no apê".

O samba me cativou e alguma coisa do funk também. Nada disso era a minha praia, mas eu estava me divertindo muito e aprendendo demais. De novo 
me senti aberta a todo tipo de música, sensação que só quem compartilhava comigo era minha mãe. Ganhei pontos com Wanderléa, durante uma entrevista, ao contar a ela que a Cristina mãe cantava seus sucessos quando fazia participação especial nos shows da Máquina do Tempo, a banda do meu pai. E, para não ficar presa só aos populares, sempre que dava, eu achava um gancho mais pop para conseguir emplacar uma pauta com algum medalhão. $\mathrm{E}$, dessa forma, até julho de 2007 - quando fui convidada a voltar para o site do jornal O Globo, não mais como estagiária de Jamari, mas agora como repórter parceira dele - fui entrevistando todo mundo que eu não queria e as pessoas que eu queria: Chico Buarque, Marisa Monte, toda a turma da Jovem Guarda - incluindo Roberto Carlos -, Jorge Mautner de novo e todos os tropicalistas, além de muitos artistas internacionais. Conquistei a simpatia de Caetano Veloso após perguntar, em uma coletiva de imprensa, se era sobre sexo que estava cantando, com sotaque lusitano, em "Porquê?", canção do álbum "Cê". Para mim, só faltou Cássia Eller, que faleceu antes de eu ter a chance de me aproximar, e Mick Jagger para eu me tornar a jornalista de música mais realizada do mundo. Pelo menos cobri o show dos Rolling Stones com o umbigo grudado na grade que separava o palco da plateia, na Praia de Copacabana, em 18 de fevereiro de 2006. Pena que, em vez de conquistar o líder da banda, assustei-o ao jogar meu colar nele. Minha intenção era ser notada por meu ídolo, mas as contas de madeira bateram no peito de Mick, que deu um pulo para trás enquanto cantava, na certa com medo de uma possível bala perdida.

As memórias sobre minha primeira entrevista com Zé Ramalho voltaram à tona em agosto de 2005, quando atravessei o corredor que separava o jornal Extra de O Globo Online, no quarto andar de um dos prédios da Infoglobo, para perguntar a Jamari se eu poderia escrever também para o site uma matéria sobre o lançamento do CD e DVD "Zé Ramalho Ao Vivo". A responsável por sua assessoria de imprensa disse que não me incluiria na agenda de entrevistas porque o músico falaria com poucos veículos, como de costume. Corri na redação vizinha e voltei com uma contra-proposta: fazer uma entrevista para 
duas matérias, uma para o Extra ${ }^{11}$ (transformada em duas retrancas ${ }^{12}$ de tanto que escrevi) e a outra para O Globo Online ${ }^{13}$. A assessora avisou, então, que Zé me daria 15 minutos por telefone. Estava bem perto do meu aniversário de 25 anos, e ele me deu um presente que nunca vou esquecer: uma entrevista de uma hora. Acredito ter sido uma exceção que abriu. E não foi difícil driblar o objetivo principal, que era falar sobre o lançamento daquele novo trabalho, afinal, tratava-se de um álbum comemorativo de 30 anos da carreira discográfica do artista. Diferentemente da entrevista em que o foco era o "Estação Brasil", nesse caso eu poderia resgatar histórias do passado, visto que o tema do novo trabalho era justamente o passado.

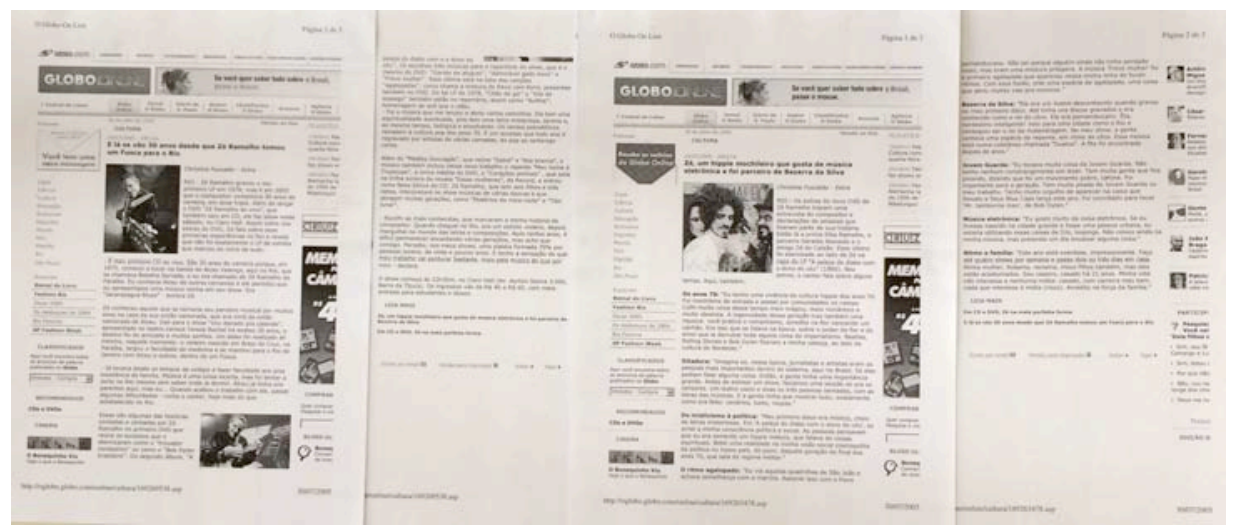

Zé Ramalho perguntou quantos anos eu tinha. Quando falei "24", ele rebateu: "E como você sabe tudo isso sobre mim?" Contei que vinha pesquisando sua vida e obra a fundo fazia mais de cinco anos, mas que tinha muito problema com a falta de registros e de arquivos e, por isso, estava fazendo perguntas tão específicas. Por telefone, ele não tinha como ver a cara de felicidade com que fiquei. Foi minha segunda grande entrevista com Zé Ramalho, só que essa era só minha. Percebi uma grande receptividade a uma jornalista por perceber nela uma espécie de afeto, gerado por uma ligação forte e gratuita com sua música. No dia do lançamento, chorei muito enquanto Zé cantava "Avôhai" no palco. Achei que era uma emoção momentânea, mas é algo

11 FUSCALDO, Christina. Uma noite para festejar. Extra, Rio de Janeiro, 30 jul. 2005, p. 3.

12 Quando excede o tamanho ideal para o veículo de comunicação, o texto é geralmente subdividido em "capítulos" agrupados por tema, chamados retrancas ou matérias coordenadas.

13 FUSCALDO, Christina. E lá se vão 30 anos desde que Zé Ramalho tomou um Fusca para o Rio. Indisponível. Acesso em: 29 jul. 2005. 
que ocorre comigo em todos os shows dele a que assisto até hoje. Deve ser culpa do "eu lírico despersonalizado" construído pelos versos, cuja capacidade, segundo a professora argentina Florencia Garramuño, "funda uma poesia em que, mesmo com uma subjetividade reduzida a sua expressão mínima, pode-se falar - e até quase constantemente - de emoções e sentidos, de sensações e sentimentos, ainda que sem sentimentalismo." (GARRAMUÑO, 2014, p.62). Depois dessa experiência, fui ao camarim do Claro Hall e, surpreendentemente, ele estava lá. Apresentei-me e pedi para tirar uma foto, a terceira da minha história com ele e a segunda da minha coleção, afinal, essa também não queimou. Feliz e me sentindo bem recebida pelo meu futuro biografado, decidi iniciar o processo de convencimento, treinando a escrita de uma nova carta.

Niterói, 5 de setembro de 2005.

\section{Oi, Zé! Tudo bem?}

Daqui a pouco estou indo te ver no Canecão, no show do projeto Loucos por Música que dividirá com os Paralamas do Sucesso. Olha só... Meu biografado e os biografados de Jamari no mesmo evento. Você já leu o livro "Vamo Batê Lata", que ele publicou em 2003? É muito interessante, porque Jamari viveu a história da banda desde o início. Ele já era jornalista atuante no mercado quando Herbert Vianna, Bi Ribeiro e João Barone começaram a

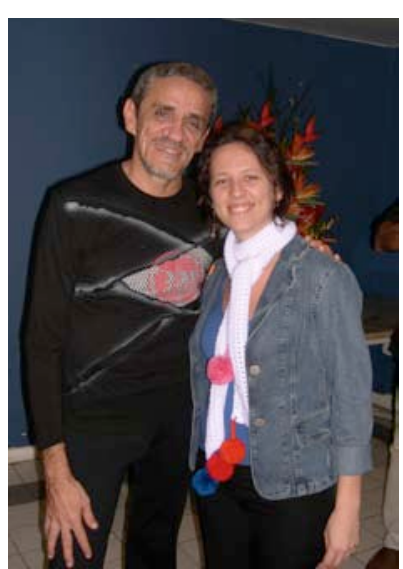
mostrar suas caras e suas músicas. Como você estava muito ocupado com seus lançamentos, com as mudanças para Fortaleza - eu soube que você morou lá na época em que estava casado com Amelinha - e, depois, para o Rio e com o período em que passou tentando se livar das drogas, não sei se você acompanhou o desenvolvimento do BRock nos anos 80. Batizado assim 
pelo jornalista Arthur Dapieve, o movimento foi responsável pelo aparecimento da Legião Urbana, Barão Vermelho, Titãs e outras bandas. O jornalismo musical impresso, a rádio Fluminense FM e o Circo Voador foram os pilares que sustentaram esses nomes e ajudaram a alçá-los à fama. Naquela época, meu crítico estava em todos os lugares. Ele conta que era normal, em dia de rock, ele ser acordado de madrugada pelo pessoal da limpeza nas casas de show.

Pelo que já escrevi aqui, você sabe que faz anos que desejo produzir uma biografia sua. Em 2002, vivi uma situação que me fez ter certeza de que era isso que eu queria. Jamari havia interrompido temporariamente a produção da biografia dos Paralamas do Sucesso depois do acidente de ultraleve sofrido por Herbert em fevereiro de 2001. Eu trabalhava na rádio naquela época e fiquei muito tempo sem entender se o vocalista se recuperaria e voltaria aos palcos ou não após a morte de sua esposa e com as sequelas que ele cultivou. Quando conheci Jama, no meio daquele ano, ele me contou que o processo era lento e que, por isso, o livro não tinha mais previsão de lançamento: não fazia sentido terminar a história daquele jeito, ou seja, sem um final. Em julho de 2002, eu e Jamari estávamos na Barra da Tijuca, cobrindo a gravação de um DVD do Vinny. Você se lembra desse rapaz, um roqueiro que vendeu sua alma à indústria gravando músicas efêmeras como "Heloísa, mexe a cadeira" e, depois que o sucesso passou, ele sumiu? Na verdade, não importa. O fato é que estávamos lá, trabalhando e nos divertindo ao mesmo tempo - eu já te disse que escrever sobre artistas mais populares é sempre divertido? - quando uma assessora de imprensa ligou para Jamari para dizer que corresse porque Herbert faria uma participação no show da banda de Bi Ribeiro, a Reggae B, no Ballroom, casa de shows no Humaitá que fechou recentemente. Dirigi que nem uma louca e chegamos em tempo de ver Herbert entrando no palco, de cadeira de rodas. As lágrimas corriam pelo rosto de Jamari e, claro, acabei chorando muito também. A emoção foi grande demais, Zé. E, dali em diante, Jama pôde voltar a trabalhar no projeto que ele tanto amava. E eu me senti um pouco mais preparada para investir no meu.

Voltando ao presente, queria dizer que este é um ano especial. Fiz 25 anos, decidi investir a sério no namoro que foi interrompido no último ano e assumi de vez a maternidade de 
uma dálmata linda. Leea fez um ano em janeiro e é uma capetinha. Você acredita que, quando era filhote, ela só dormia quando eu cantava músicas da Rita Lee? Por isso dei esse nome a ela. Mas o mais engraçado é que ela quase não late, a não ser quando olha para o pôster do "Estação Brasil" que está atrás da porta do meu quarto. Acho que ela fica com medo de você, com as mãos na cintura e com aquele olhar profundo. Morro de rir.

Na realidade, escrevo para avisar que, em breve, farei a proposta a você. Estou estudando a melhor maneira de me aproximar para pedir que me autorize a escrever sua biografia. Creio que tentar uma nova entrevista não seria o caminho mais fácil. Será que é methor eu entregar esse caderno a você? Na última carta, eu perguntei se não entregar essas cartas fazia eu me sentir menos abusada. Tem dias em que acordo querendo que leia meus escritos. Há outros em que levanto com vontade de queimar tudo, tanto o que está aqui no caderno quanto os meus diários, assim como o poeta inglês Ted Hughes fez com algumas páginas do diário de sua mulher, Sylvia Plath, depois que ela se suicidou. Mas aí lembro da biógrafa Janet Malcolm contando em seu livro que isso tornou sua pesquisa sobre a poetisa americana mais difícil e ainda colocou 0 viúvo em uma situação delicada, afinal, por que ele teria interesse em esconder os desabafos de Sylvia? Por causa disso, a jornalista não tem a menor condição de contar parte de uma história e nós, leitores, nunca saberemos a versão da história contada pela biografada. Não quero fazer a mesma coisa que Hughes. Bom, mas vamos falar do que você não escondeu. Um dia, você vai ser o meu biografado, está vivo e não deve ter queimado tanto material assim. Naquele dia da entrevista, você comentou que guarda muitas coisas em seu arquivo. No futuro, quero acessá-lo!

Não sei se tenho coragem de te entregar esse caderno, Zé, mas sei que o pedido deste ano não passa!

Um beijo,

Chris Fuscaldo 


\section{Um livro de colagens para convencer Zé Ramalho}

Inspirada pela história de meus chefes, autores de uma biografia sobre os Titãs chamada "A vida até parece uma festa", fui em busca do endereço de Zé: para apresentar o projeto à banda, Hérica Marmo e Luiz André Alzer enviaram cartas aos integrantes no dia em que eles se encontrariam para uma reunião e certamente comentariam a proposta. Flertando com a possibilidade de voltar a namorar Adilson, que tinha terminado comigo um ano antes e vinha tentando uma reaproximação, pedi ajuda a ele, na época funcionário de uma gravadora. Criei coragem e, em 3 de outubro, deixei flores, um cartão e um envelope amarelo contendo um livro - não o meu caderno, que nessa fase me fazia sentir vergonha, mas um outro livro em branco cuja capa pintei de preto e na qual colei uma foto de Zé e escrevi uma sugestão de título. Dentro, recortes de jornais e textos iniciavam a narração da trajetória de Zé Ramalho e um resumo da minha história. No final, eu me propunha a escrever a sua biografia. No verso do envelope, não coloquei o remetente. Na frente, escrevi “A/C Zé Ramalho".

Niterói, 03 de outubro de 2005.

Caro Zé Ramalho,

Feliz aniversário! Mais informações, no envelope amarelo.

Abraços, 
Para cada uma das páginas que precediam as dos recortes, criei um capítulo. E ficou assim:

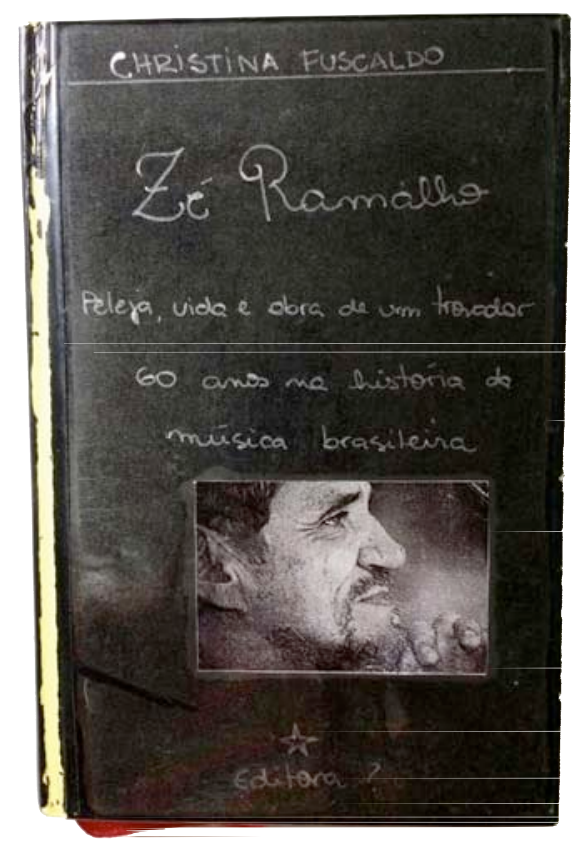

\section{Nota}

Mau feito? A ideia era mostrar que sou melhor com textos do que com trabalhos manuais e meu objetivo é mostrar o que sou capaz de fazer para chamar sua atenção.

\section{Capítulo I - O personagem da minha vida}

Outro dia, uma amiga jornalista me confidenciou: "Eu escrevi um livro sobre os personagens da minha vida." Ela quis dizer que tinha feito a biografia daquela que foi a primeira banda a conquistar seu coração. Isso me fez pensar e chegar a algumas conclusões.

\section{Capítulo II - Conclusão I}

Estava eu no Sul de Minas Gerais quando ouvi "Avôhai" pela primeira vez. A música entrou em mim de uma maneira que não dá para explicar com palauras. Eu tinha 18 anos. Voltei e 
corri atrás de discos, livros, vídeos sobre o autor daquela canção. 0 material serviu para uma coisa eu concluir: Zé Ramalho é o personagem da minha vida.

\section{Capítulo III - Minha vida}

Conheci Beatles e Rolling Stones com meu pai, Wanderléa com minha mãe e Jimi Hendrix e Led Zeppellin com meu irmão. Ouvi muito Ataulfo Alves e Nelson Gonçalves com minha avó. No colégio, descobri Gilberto Gil, Caetano Veloso, Chico Buarque etc. Não tive escolha senão me apaixonar por... Música! A princípio não mostrei nenhuma inclinação para os instrumentos. Sempre fui afinada, mas nunca demonstrei vontade de soltar a voz. Meu negócio era ler música, ouvir música, assistir à música e, depois de um certo momento, escrever sobre música.

Foi quando esbarrei com Zé Ramalho que todos os outros artistas, para mim, viraram um só. Aquela voz forte e poderosa, a poesia ora simples ora incompreensível e a mistura de ritmos me levaram a lugares incriveis. Para o pronome "me" leia "imaginação". Contei para meu pai o meu mais novo segredo e descobri que seu armário encantado também guardava discos do artista.

Com as matérias que escrevi sobre o personagem da minha vida, ouvi pessoas se dizendo curiosas para conhecer melhor Zé Ramalho. Uma colega chegou a pedir meu DUD emprestado. Percebi que posso mexer com o imaginário do leitor.

\section{Capítulo IV - O meu imaginário}

Quando leio algo que me faz ter sensações no corpo é porque o texto em questão mexeu com meu imaginário. Foi assim com muitos liuros, entre eles "A divina comédia dos Mutantes", do Carlos Calado, "Jovem Guarda em ritmo de aventura", do Marcelo Fróes, e "Noites tropicais", do Nelson Motta. Foi assim também com vários clássicos da literatura brasileira, como "O cortiço", do Aluísio Azevedo, "Os sertões", do Euclides da Cunha etc. Mas a questão agora é a música. Desde que comecei a ler biografias musicais passei a ter vontade de ser uma dessas pessoas que mexem com o imaginário das outras. 


\section{Capítulo V - O meu personagem no imaginário alheio}

Preciso dizer alguma coisa?

\section{Capítulo VI - Mãos na massa}

Sim, as duas mãos. Uma segura o lado esquerdo desse liuro e a outra escreve. Há tempos eu não fazia nada com as mãos além de teclar no computador. Quis ser original e mostrar minha identidade também através da minha caligrafia. Aqui, sou eu.

\section{Capítulo VII - A proposta}

Quero escrever a sua biografia, Zé. Quero contar ao mundo a sua história, com riqueza de detalhes e quero que ela seja autorizada.

\section{Capítulo VIII - A história do Zé Ramalho}

Por que não contar para todos quem é, de onde veio e qual a importância de um homem que passou dificuldades, foi acusado de plágio, foi apelidado de Bob Dylan do Sertão, gravou, fez sucesso, caiu e se levantou? Zé Ramalho fez uma história que merece ser revelada.

\section{Capítulo IX - O livro}

Que tal me permitir preencher um liuro como este (ou maior) com a sua história?

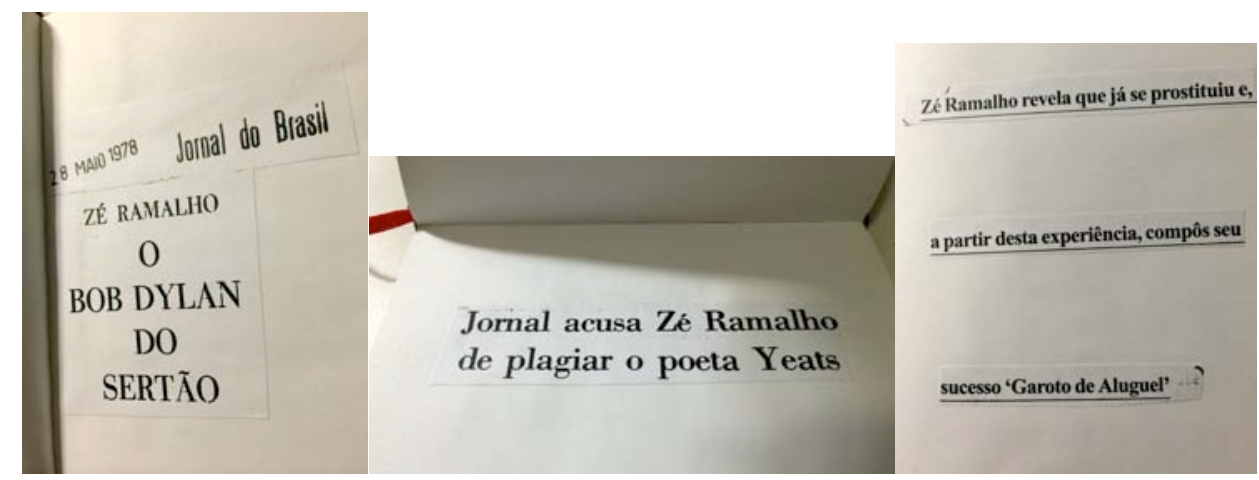




\section{0 som do silêncio}

Não sou Paul Simon nem Art Garfunkel ${ }^{14}$, mas naquele final de 2005 ouvi o som do silêncio. Zé Ramalho não emitiu uma palavra, não escreveu uma carta nem mandou recado. Eu preferia que ele fosse como Mário, que, segundo Manuel no prefácio do livro onde compilou as cartas que trocava com o amigo, "nunca deixou uma carta sem resposta" (ANDRADE, 2001, p. 13). Passei, então, o fim do ano entretida em resolver minha vida amorosa e muito curiosa para saber se aquele homem esguio tinha recebido ou não tudo o que deixei em sua portaria. Na noite de Ano Novo, na virada para 2006, só com o pé direito no chão e cheia de inocência no coração, fiz o meu pedido em voz baixa: "Que Zé Ramalho me dê autorização para escrever a sua biografia!" Em janeiro, tive as primeiras férias remuneradas da minha vida e, após mais uma fase conturbada no namoro, que acabou em um novo término, fiz uma viagem a Cuba. Na volta, aluguei um quarto em um apartamento no Catete dividido por um casal gay que, apesar de jovem, adotou-me como filha, e um músico gaúcho que, enquanto eu tomava banho, ficava tocando violão na cozinha para me ouvir cantar pelo basculante do banheiro. Certa noite, sentada na minha cama, fiquei meio angustiada, não resisti e fiz uma longa carta para o Zé. E não foi no livro caderno, que, em meio a tantas mudanças, acabou ficando em Niterói. Escrevi "A/C Zé Ramalho" em um envelope vermelho e o deixei lá no Leblon.

14 Dupla de compositores norte-americanos e autores da canção "The sound of silence", lançada originalmente em 1964. 
Rio de Janeiro, 10 de fevereiro de 2006.

Caro Zé Ramalho,

Faz pouco mais de quatro meses que aguardo ansiosamente um retorno seu sobre a proposta que te fiz de escrever sua biografia. Será que você recebeu o presente que deixei na sua portaria? Será que tem alguém filtrando o que deve chegar até você? Vai ver não gostou da ideia, mas prefere não falar. Acho isso ruim, Zé. Primeiro, porque eu estou na expectativa e você deve imaginar o quão ruim é ficarmos esperando. Você mesmo já passou por isso muitas vezes ao longo de sua carreira. $E$, depois, porque não posso esperar a vida toda. Acho que, no dia em que eu cansar desse silêncio, você vai perder a chance de ter uma pessoa realmente apaixonada por sua história disposta a escrevê-la. Não há nada que eu possa fazer a não ser continuar esperando, torcendo e avaliando até quando vale a pena deixar outros projetos que poderia estar tocando de lado para seguir investindo no seu. Mas, como disse Graciliano Ramos em uma das cartas que escreveu à irmã Leonor, "escrever somente por gosto, para não ter resposta, não é nada consolador". Bom, sei que não adianta ficar ansiosa. Melhor focar no assunto que quero tratar. Mando esta carta para falar sobre a pesquisa que sigo fazendo.

Nesse momento, tenho um vasto material, inclusive duas entrevistas ótimas que fiz com você - que já me ajudaram a esclarecer grande parte das dúvidas que tinha em relação a alguns acontecimentos sobre os quais tinha lido ou escutado falar. Você se lembra que, na entrevista que deu em 2003 a Jamari França, ele foi acompanhado de uma jovem que te convenceu a comentar temas nada primários? Você se lembra que continuaram a conversa no almoço e que a pupila de Jamari se sentou do seu lado? Era eu! Sim, era eu. Aposto que você não sabia que aquela era a mesma jornalista de 24 anos com quem você deixou a entrevista fluir pelo telefone. Mas que essa profissional com quem se relacionou em 2005 é a mesma pessoa que te propôs fazer a biografia, isso você sabe! Afinal, tudo está no liuro que deixei em sua portaria. A não ser que ele não tenha 
chegado até você. Se isso aconteceu, é capaz de essa carta também não chegar. Mas não é por isso que vou deixar de te dizer o quanto fiquei feliz, tanto quanto te entrevistei ao lado de Jamari, quanto quando percebi que você estava impressionado com o fato de eu ser tão nova e saber tanto sobre sua vida e obra. É porque sou uma grande admiradora de sua obra e uma jornalista curiosa sobre sua vida que insisto na proposta de escrever a sua biografia. E quero fazer uma autorizada. Não que tenha inclinação para a escrita de textos chapa branca. Não mesmo! Quero contar a história que aconteceu exatamente como aconteceu e sei que você terá orgulho de vê-la documentada. Viver tudo o que você viveu não é para qualquer um, Zé. E otha que eu devo estar sabendo de menos da metade, visto que não fiz todas as entrevistas necessárias. Eu queria ter lido algo consistente sobre você. Já que não existe nenhum livro, espero que me deixe fazer o meu.

Olha só... No começo deste e-mail, tentei ser dura e te mostrar que essa espera por um retorno não está sendo legal, mas foi só lembrar dos acontecimentos que me levaram a te fazer tal proposta que já amoleci. Vou te confessar algo bem íntimo, Zé. Espero que as mensagens não estejam sendo lidas por algum homônimo cujo endereço me foi fornecido por engano. Ainda tenho esperanças de que meus sentimentos ajudem a sensibilizá-lo, afinal, acredito que escrever uma biografia não é um trabalho como outro qualquer. Acredito que é preciso haver algum envolvimento com o biografado. Zé, fico emocionada cada vez que lembro dessas duas entrevistas que fiz com você. Sério. Não é a mesma emoção que senti quando ouvi "Avôhai" pela primeira vez, porque ali tratava-se de algo que não consigo explicar, que deve vir do além. Nesse caso, é uma emoção causada pelas memórias. Uma mistura de nostalgia com orgulho por ter vivido tais experiências. Pronto, falei! Ou melhor, confessei! Espero que não me entenda mal. Não sou uma fã daquelas que fazem de tudo para se aproximar do ídolo. O mesmo que estou fazendo com você, fiz com Rita, Sérgio e Arnaldo na época em que estava escrevendo minha monografia da faculdade, sobre Os Mutantes. Pesquisei, vasculhei arquivos e entrevistei os dois primeiros - Arnaldo não me foi liberado pela esposa - e fiquei um ano inteiro sugando o que podia. Por isso digo que, caso não me 
dê resposta, em algum momento escolherei algum nome que me inspire a investir em outro projeto. Enquanto isso, sigo tentando esgotar minha necessidade de entender você e a sua trajetória.

Acredito que, apropriando-me de sua história, estou absorvendo conhecimento não só sobre você como também sobre os artistas com os quais se relacionou, sobre os circuitos que frequentou, sobre a vida cultural e política dos tempos em que você viveu e, acima de tudo, estou aprendendo muito sobre o Nordeste, que só conheço de ouvir falar. Você acredita nisso? Pois é. Sei bastante sobre o cangaço e sobre o bando de Lampião, entendo mais sobre forró de Luiz Gonzaga do que sobre samba carioca e, na minha casa, coloco muitos ingredientes de lá na culinária, mas nunca tive a oportunidade de visitar nenhuma capital nordestina. Fui em uma excursão com a escola a Porto Seguro, na Bahia, mas não considero aquela uma viagem culturalmente rica. Ficamos só na praia e nos eventos de axé que os anfitriões prepararam para nossa recepção. Ah, sim, lembro de ficar impressionada com a casa que disseram ser de Elba Ramalho, em Trancoso. Soube que, apesar de paraibana, ela é uma grande fã da praia baiana. Mas, tirando isso e um encontro com índios da tribo Pataxó, a viagem não acrescentou muito, não. Então, Zée, falo isso para dizer que me aprofundar em sua história me faz crescer como pessoa e como profissional. Não quero só ter a imagem do sertanejo pintada por Euclides da Cunha em "Os sertões". Muito menos desejo ter a imagem do sertanejo que essas duplas famosas mostram na televisão, dos caras de chapéu que em seu canto falam da terra, do gado e do amor e são vencedores por ganharem muito dinheiro no showbusiness. Quero conhecer o sertanejo que seu avô foi, o que você ainda é e o que evoca em sua canção. Aliás, Zé, quero entender melhor as evocações que faz em suas letras. Aproveitando, eu queria falar sobre Avôhai. Não sobre o nome da canção, mas sobre o mito que se criou em torno do personagem que o inspirou a escrevê-la: José Alves Ramalho, o avô que fez o papel de pai para você.

Faz 30 anos que ele faleceu. Imagino que você também esteja atento à data e, provavelmente, sentindo uma saudade enorme do homem que te criou. Quero entender melhor o sentimento mais profundo que carregas em relação a esse senhor: o que sentes quando canta 
"Avôhai" e evocas o homem que ajudou a te formar e fazer de ti o sujeito que és? Levanto essa questão lembrando da reação do público em todos os shows seus a que assisto. É quase uma seita. Parece uma religião. Todos evocam Avôhai como se estivessem chamando Deus, mas sem se dar conta do que está por trás desse seu Deus já morto e do que significa para você essa morte, que foi real, vista de perto por você e, por isso, muito dolorosa. Não foi à toa que, naquela noite no Teatro Santa Rosa, em João Pessoa, três dias após o falecimento de José e quatro meses antes de você embarcar para o Rio para investir no seu projeto de vida, você dedicou o show da Coletiva de Música da Paraíba a seu avô, evocando o seu Deus morto. Estou aqui vestindo seu avô de Deus porque sei que sua religião é a sua familia. Se Nietzsche fala do Deus institucional, esse criado pela Igreja Católica, você fala de um Deus familiar. Sei que você não segue uma religião como faz a sua avó, dona Soledade, católica fervorosa, homenageada inclusive na letra de "Avôhai" quando você destaca o "terço de brilhante nos dedos de minha avó". Pensando em sua familia como um sistema cultural de crenças e visões de mundo, não tem como não pensar em seu avô como a divindade maior desse sistema.

Você havia composto essa música e mostrado para seu José no Natal de 1975, na casa de Manaíra, aquela que inspirou a música "Vila do Sossego", na verdade, a casa da sua tia Teresinha onde você morou com Ísis, sua primeira mulher. Você ajoethou-se com sua viola e cantou, emocionando tanto o velho quanto todos os outros integrantes da familia. Seu avô colocou mão na sua cabeça e, chorando de emoção, te abençoou. Mal podiam imaginar seus familiares que essa canção brotou em você como se tivesse sido psicografada e isso ocorreu durante uma viagem promovida por um ácido que você tomou. Tem coisas que a gente não comenta com nossos parentes para não machucá-los, né? Eu também não contei a meus pais quando experimentei maconha. No meu caso, o tiro saiu pela culatra: eles descobriram e eu acabei em uma inquisição familiar seguida por uns tabefes dados por minha mãe. Lá em casa, era como na de Keith Richards: mamãe era a única que me dava umas palmadas de vez em quando. Pior é que o negócio nem tinha dado onda. Eu tentei fumar algumas outras vezes, mas nunca foi muito legal, quase 
sempre me dava sono ou paranoia, ou melhor, a famosa bad trip. Acho que tinha a ver com o fato de minha mãe ter um primo esquizofrênico que vivia dizendo que ficou assim "por causa do tóxico". Toda a minha familia ficou com certa aversão a qualquer tipo de entorpecente e acabou sendo meio óbvia minha opção por não experimentar as drogas ditas mais pesadas. Está aí uma diferença entre mim e você: enquanto as drogas te estimulam, a mim elas amedrontam. Mas não sou contra. Pelo contrário. Adoraria que todas fossem descriminalizadas. Convivo com muitas pessoas que as usam e seria ótimo não ficar tensa quando o fazem em certos locais.

Voltando, você seguiu tocando essa música, mas, com a morte do Avôhai, imagino que o significado tenha mudado bastante. Avôhai não é um nome próprio real, mas um nome que você - ou seja lá quem enviou a mensagem durante sua onda lisérgica - deu a esse personagem que existiu e que assumiu sua criação depois que seu pai verdadeiro morreu. Assim como Nancy, um filósofo francês que ando lendo ultimamente, acredito que não se chama a um nome próprio sem pensar no significado que ele tem. Ele diz que, quando chama a Deus, não necessariamente está praticando a religião, mas que há de se considerar o sentido que a palaura tem. Fico imaginando, então, que você também não está rezando para José Alves Ramalho quando canta a canção, mas algo acontece em seu corpo, seja no cérebro, seja no coração. Ainda pensando nas leituras que fiz de Nancy, tem uma questão que me incomoda. Ele diz que é livrando-se de Deus que se consegue alcançar a "pobreza de espírito", ou seja, livrar-se das amarras que a religião proporciona. Vestindo nosso querido Avôhai com essa roupa de Deus e lembrando que você o evoca toda vez que sobe em um palco, não seria essa relação uma amarra da qual você não quer se livrar? Sei que você tem as melhores lembranças dele. Se eu sinto saudade do avô que nem conheci, fico imaginando o vazio que ficou em você após a morte do seu Deus. Acredito que cantar para ele seja a forma que encontrou para seguir em frente sem sentir a solidão que sua ausência deixou. $E$, ainda hoje, evocar o seu "avô e pai" deve the proporcionar um conforto muito grande, uma certeza de que você não está só. Será que é uma sensação parecida com a que eu tive quando ouvi "Avôhai" pela primeira vez? 
É por essas e outras questões que não consigo desistir da ideia de escrever a sua biografia. O público que evoca o Avôhai junto a você precisa saber quem foi esse homem, sua relação com ele e o que acontece quando ainda, depois de 30 anos, você canta a mesma canção.

Ainda no seu aguardo,

Christina Fuscaldo 


\section{Então, ele já sabia que eu era eu}

Dois mil e seis foi o ano em que tentei enquadrar Zé Ramalho durante um show de Oswaldo Montenegro no Canecão. Zé chegou depois que as luzes já tinham se apagado e se levantou antes de elas serem acesas. Aliás, essa é uma das manias dele descobertas por mim durante minhas pesquisas. Na medida em que lia (em jornais e revistas), perguntava (a parceiros em entrevistas) e escutava (suas músicas e depoimentos gravados para DVDs, programas de rádio e de TV), também absorvia muitas informações que antes eu ignorava. Sentada mais ou menos no meio da plateia, reconheci aquela silhueta. Passei a maior parte do espetáculo planejando como abordá-lo. Era a primeira vez que o encontrava fora de seu ambiente de trabalho: antes, eu só tinha visto Zé Ramalho no dia da entrevista com Jamari, no palco e, por sorte, no camarim. Naquela noite, quando flagrei aquele homem alto e magro, de pernas muito finas e com pouco rebolado em seu jeito de andar, saindo à francesa com sua esposa, corri pela plateia escura da casa de shows e consegui alcançá-lo na lateral. "Zé, desculpe te abordar assim, mas eu queria me apresentar: sou Christina Fuscaldo, aquela que quer escrever a sua biografia." Zé e a mulher se assustaram, mas me ouviram. "Oi, Christina. Não se preocupe que um dia vamos falar sobre isso", escorregou ele. "Puxa", pensei, "mas quando?" Enquanto via o casal apressando o passo para chegar à porta de saída antes que Oswaldo se despedisse de seus fãs, fiquei pensando sobre o que pensar sobre aquela resposta. Com a vida profissional indo de vento em popa, com um apartamento alugado junto a Adilson em um dos bairros que eu mais gostava no Rio, Laranjeiras, e sentindo-me mais à vontade para planejar lindas viagens, eu andava otimista em relação à vida. Dessa forma, naquele momento, tentei achar o lado bom do encontro com Zé: pelo menos descobri ali que ele havia recebido as minhas cartas e estava analisando a minha proposta. Escrevi mais uma. Só lamento não ter lido, na época, o livro de Paula Dip sobre seu amigo, Caio 
Fernando Abreu, publicado somente em 2009, no qual a jornalista retira de uma carta do escritor, escrita em 1980, uma previsão do futuro: "Os astrólogos estão dizendo que deve-se aproveitar o mundo até 82/83, porque aí começam umas posições astrais da pesadíssima." (DIP, 2009, p. 47). Parece que ele estava escrevendo para Zé Ramalho, que só se reergueu no fim dos anos 90 e virou um mito depois dos 2000 , tema que comentei nesta nova correspondência: "E como o social é a soma dos individuais, quem sabe nos anos 90 haverá a síntese e depois de 2000 a grande transformação?" (DIP, 2009, p. 48)

Rio de Janeiro, 10 de outubro de 2006.

Caro Zé Ramalho,

Sabendo, agora, que é você mesmo quem me lê, o Zé Ramalho a quem venho destinando cartas, escrevo novamente para tentar mais uma vez (e talvez seja a última) convencêlo de que mereço sua confiança. Já faz pelo menos um ano e meio que tento um contato e não tenho um retorno e, porque não gosto de ser, parecer ou me sentir inconveniente, estou planejando abortar a missão. Ando recebendo convites para participar de projetos muito sedutores e não vejo por que continuar perdendo meu tempo com uma pesquisa que não vai me levar a lugar algum e, 0 que acho ainda pior, sequer me ajudou a conquistar o seu respeito ou obter o mínimo de sua atenção. É claro que sei que não tens obrigação nenhuma de responder as minhas cartas nem muito menos de gostar de mim e da ideia de permitir que eu seja sua biógrafa. Mas, como a esperança ainda não morreu, decidi tentar mais uma vez. $E$ aproveito esta correspondência para pedir desculpas pela forma como te abordei naquela noite, durante o show de Oswaldo Montenegro. Eu estava acompanhando cada passo seu desde a hora em que pisou no Canecão. Como você não responde meus chamados, vi ali uma oportunidade. Desculpe-me se, além de te surpreender, invadi sua intimidade e ainda, de certa forma, coloquei você contra a parede. Minha 
intenção era te mostrar que eu estava na área e que seguia te esperando e, também, sondar se você tinha recebido ou não o presente e a carta que deixei em sua portaria no dia do seu aniversário, no ano passado. Pela resposta que me deu, pelo menos consegui confirmar que sim. Se não me deu qualquer retorno até agora, imagino que seja porque não te agrada a ideia de me dar a autorização. Só não entendo porque ainda não me disse um "não". Mas, como não quero mais me sentir chata e invasiva, tomei a decisão de, após este contato, não te escrever mais.

Insisti no tema de novo na semana passada, novamente no dia do seu aniversário. Deixei na sua portaria flores, um boneco de biscuit que comprei de um hippie em Visconde de Mauá e outra carta, dando-the parabéns e tocando novamente no assunto. É, Zé, para você pode parecer que, uma vez por ano, perto do seu aniversário, vou à floricultura, escrevo uma carta, penso num presente e pronto. Mas não é bem assim. Não tem uma visita a uma loja de discos, a uma feira de vinil, a uma livraria, à Biblioteca Nacional e ao centro de pesquisa da Infoglobo, onde eu trabalho, em que eu não pare para procurar gravações, publicações ou algum arquivo, raro ou não, que possa me fornecer mais informações sobre sua trajetória. E nas entrevistas que faço, sempre dou um jeito de perguntar aos artistas se eles têm ou tiveram alguma relação com você que possa ter deixado memórias ou recordações dignas (ou não) se serem guardadas ou divulgadas a mim, uma pesquisadora aspirante à escritora. Assim tem sido minha vida desde 1999, desde que te escutei pela primeira vez. Falo em escutar porque ouvir eu já tinha ouvido na época de Roque Santeiro. Eu tinha quatro ou cinco anos e ficava apavorada cada vez que o Professor Astromar virava lobisomem e atacava as mocinhas da cidade: "Mistérios da meia-noite", que você compôs para a trilha sonora da novela exibida entre junho de 1985 e fevereiro de 1986, só me deixava com mais medo. Que música macabra, Zé! Na época, eu não sabia que era sua. Eu achava que 0 professor Astromar era o autor, assim como passei anos acreditando que meu pai tinha composto "Canteiros", o clássico de Fagner que ele interpretava com maestria nas rodas de violão com os amigos. Hoje, sabendo que o lobisomem não existia, mas era um personagem interpretado pelo ator 
Rui Resende, posso te dizer que adoro a canção. Adoro mais ainda saber que ela te ajudou a sair de uma das piores fases da sua vida profissional.

Quando lançou seu quarto disco, "Força verde", em 1982, você foi acusado de plágio por jornalistas, que publicaram matérias em que diziam que você roubou para a faixa-título os versos de um poema do William Yeats. Mesmo explicando que havia se inspirado em frases lidas em uma revista em quadrinhos do Incrivel Hulk que pegou emprestada de Geraldo Azevedo - e que não dava o crédito ao poeta irlandês - você assumiu o erro, só que a mídia foi cruel e explorou 0 "escândalo" até onde pôde. Para eles, foi só mais uma matéria sensacionalista. Para você, foi o início de uma derrocada que só iria se resolver muitos anos depois. O triângulo formado por sucesso, dinheiro e respeito, coisas que conquistou entre 1978 e 1981, ano do lançamento de seu terceiro disco, "A terceira lâmina", você só reconquistou novamente 15 anos depois, quando lançou o "Antologia acústica”. Entre 1982 e 1997, foi uma sequência de altos e baixos que deve ter sido muito angustiante. Nessa gangorra, seu primeiro grande êxito foi justamente "Mistérios da meia-noite", que agora sei que te alçou novamente à fama durante aquele período. E eu, na época tão ingênua, cheia de medo do professor Astromar! O efeito sugerido pelo produtor musical da TV Globo Mariozinho Rocha, de você criar uma canção sinistra para um personagem sinistro, funcionou perfeitamente em mim. A ideia de você recitar uma frase entre um canto e outro deixa muitas de suas músicas com esse tom bizarro. E essa, especialmente, precisava disso. Quando você cantava "se vão, se ficam" e emendava na récita "quem vai, quem foi", a sensação era de que o professor estava se aproximando de alguma das vítimas. Que pavor eu ficava de, um dia, o homem que virava lobisomem conseguir entrar no apartamento onde eu morava com meus pais. Mal sabia eu que, se não fosse aquela música que ajudava a tornar a cena mais convincente, talvez você nem existisse mais no circuito musical ou mesmo nesse plano em que vivemos. Sim, porque você estava financeiramente arrasado e pessoalmente devastado quando recebeu esse convite. Seus discos de 1983 e 1984, "Orquídea negra" e "Por aquelas que foram bem amadas", são muito bons, mas na época não tiveram a repercussão que você gostaria, certo? Que bom que 
aproveitou o sucesso da faixa, incluiu-a no álbum de 1985, "De gosto, de água e de amigos", e voltou aos palcos para uma turnê que te ajudou a pelo menos quitar as dívidas que tinha feito com a gravadora na época das farras à base de álcool e drogas oferecidas a "amigos", entre eles Raul Seixas. E eu só fui saber que era você o sonoplasta do meu medo de infância em 1999, quando meu pai me entregou os discos seus que ele tinha em casa e, de quebra, emprestou-me o da trilha sonora de Roque Santeiro, onde figurava seu nome.

Despeço-me desta etapa da minha história com você, mas não sem antes comentar alguns temas que têm me atormentado muito. Um deles tem tudo a ver com o sentimento que ando tendo desde que nos falamos, na escuridão do Canecão: a sua relação com a imprensa. Você sempre criticou os jornalistas pela maneira como eles se dirigiam a você e pela forma como eles criticavam sua música, mas você parece nunca ter parado para pensar em como seu comportamento colabora para a formação de uma imagem, digamos, assustadora. Difícil, pra mim, é saber o que surgiu primeiro, se foi o ovo ou a galinha, ou seja, se foi a crítica nada amigável ou o artista criticado por não ser nada simpático. Fico tentando imaginar o que te deixou assim, tão duro e aparentemente amargo. Lembro de ouvir uma assessora de imprensa comentar que, quando lança algo, você escolhe dois ou três veículos para dar entrevistas. Antigamente, você baixava mais a guarda e falava a diversos veículos. Tenho uma pilha de fotocópias de matérias que foram publicadas ao longo desses quase 30 anos de sucesso. As primeiras são de 1976, ano em que chegou no Rio, mas tenho muitas de 1978, quando lançou seu primeiro disco pela CBS e explodiu no Brasil. Há textos ruins, críticas rasas e pouco fundamentadas e entrevistas mal aproveitadas. Mas há também destaques ótimos, com elogios e bons debates sobre sua música e seu papel na cena musical brasileira. Nelson Motta foi um dos primeiros a levantar sua bola aqui no Rio, com notas e comentários na coluna que assinou no jornal O Globo de 1973 a 1980 le, depois, de 1995 a 2000). E tem ainda o José Nêumanne Pinto, seu conterrâneo, autor de uma série de matérias muito bem escritas e embasadas a seu respeito. Não é possivel que, na sua concepção, o mal tenha que vencer o bem e te fazer crer que apostar em nós, jornalistas, não vale a pena. Eu sei 
que há profissionais menos sérios ou, simplesmente, menos preparados. Mas, apesar de ser nova e ainda estar verde em alguns aspectos, sinto que já sou respeitada por muita gente por já ter provado que não estou aqui para brincar. Lamento muito ainda não ter conseguido te conquistar.

Reparei que já havia uma certa revolta em você antes mesmo de dar início à carreira profissional de músico. Há quem diga que você é um vulcão cuja larva é constituída por elementos como sensibilidade, respeito, carinho, generosidade e educação. Mas, enquanto não rola uma explosão, aquela montanha fica ali, parada, imponente, cheia de empáfia, assustando a qualquer um que passe por perto. Como não te conheço tão bem assim, para mim, parece que é o contrário: 0 vulcão fica ali na dele e, quando entra em erupção, sai queimando tudo e todos que estão em volta. Falo isso porque sempre me lembro de histórias que você mesmo conta e que contam sobre o período em que começou a trocar a função de guitarrista do The Gentlemen pela de compositor e violeiro. Você se envolveu com o pessoal de Recife e não demorou muito para, em 1975, gravar seu primeiro disco, o "Paêbirú - Caminho da montanha do sol", e ser convidado por Alceu Valença para acompanhá-lo no Festival Abertura da TV Globo e, depois, para tocar em sua banda no show "Vou danado pra Catende", no Rio e em São Paulo. Para muitos músicos, aquela era uma oportunidade para não ser jogada fora, era a chance de conquistar um espaço fora da Paraíba e de Pernambuco. Ou melhor, era a oportunidade que vocês estavam tendo de se tornarem conhecidos no Sudeste e, consequentemente, no Brasil todo. Mas aposto que isso nem passou pela sua cabeça quando reagiu ao puxão de orelha dado por Alceu e o enfrentou, no palco, mesmo sendo ele o dono daquele show. Não sei e não saberei enquanto você não me contar o que passou pela sua cabeça quando decidiu mudar o roteiro e entoar "Vila do Sossego" em vez de "Jacarepaguá blues", que Alceu te deixava tocando enquanto fazia um pequeno intervalo no camarim. Muito menos consigo compreender porque você não aceitou a bronca e pediu desculpas. E o pior: o que você estava buscando quando quebrou o violão dele no palco? Até posso imaginar que foi um acesso de raiva ou um ataque de fúria, mas sempre achei que você só teve coragem de fazer aquilo porque estava sob efeito do LSD. Agora, acho que não. Creio que você explodiria daquele 
jeito de qualquer maneira. Tanto que, no ano seguinte, você entrou em erupção no palco do Teatro Santa Rosa também.

Na Coletiva de Música da Paraíba, organizada por Pedro Osmar em maio/junho de 1976, você cortou os cabelos, quebrou uma televisão e sacrificou mais um violão. Apesar de eu achar que queria mostrar a sua força para Alceu no "Vou danado pra Catende", você disse que estava homenageando Sérgio Ricardo. No seu próprio show, parece que a ideia era deixar sua marca para que ninguém se esquecesse do que viu. Você queria que todos ali soubessem que aquele artista, rechaçado pela crítica e mal visto por uma camada da sociedade paraibana, era um homem de personalidade marcante, um nordestino pronto para brigar pelo seu espaço, um sertanejo forte que não se deixava abater pela altivez de qualquer outra pessoa que se julgasse melhor. Acho que consigo entender um pouco o sentimento de revolta contra aqueles que te julgam. Lembro que, quando era adolescente, eu também enfrentava aqueles que me julgavam e partia para cima dos que condenavam as pessoas que eu amava. Então, não me sinto tão distante assim de suas histórias. As minhas reações, eu sei porque se dão, mas as suas, só se você me contar poderei entendê-las e, desta forma, incluílas em sua biografia. O que me soa estranho é, depois de tantos anos, tantas vitórias, tantas conquistas, você ainda carregar algo que eu chamaria de mágoa. Só você pode me dizer se é isso, mas é o que me vem à cabeça quando tento entender a distância que ainda mantém dos jornalistas. Será que um dia você vai me explicar? Também gostaria muito de saber como e quando você e Alceu fizeram as pazes e como foi voltar a tocar com ele na época de "O grande encontro", em 1996. Foi um fenômeno em número de vendas e de público, mas você, Alceu, Elba Ramalho e Geraldo Azevedo brigaram muito durante todo 0 processo, né? É o que falam por aí.. E eu acredito, afinal, Alceu acabou saindo antes da gravação do segundo volume do álbum e também não participou do terceiro. Você já não gravava discos há quatro anos e não estava numa fase muito boa de sua carreira quando surgiu a oportunidade de participar deste projeto. Mesmo assim, não deixou que ninguém te colocasse em posição de inferioridade ou algo assim. 
Essa postura que me intriga ao mesmo tempo em que me faz admirá-lo mais ainda. Acho incrivel que um homem consiga, mesmo em seus piores momentos, enfrentar a vida com 0 queixo empinado como você faz. Zé, você firmou sua identidade e, com sua austeridade, não se deixou abater pela alteridade ou pela autoridade de ninguém. Por outro lado, acho que um pouco de humildade teria te ajudado muito em diversos momentos de sua vida, tanto pessoal quanto profissional. Na época em que estava passando necessidade no Rio de Janeiro, entre 1976 e 1978, quando se mudou para cá e ficou em busca de oportunidades, imagine se você fosse um cara mais flexível? Não tenho como ter certeza, mas acredito que suas conquistas teriam sido alcançadas mais rapidamente. Acredito que você não teria levado quase dois anos para conseguir pedir o prato que quisesse em um restaurante ou para ter uma cama confortável para dormir. Nos dois anos em que fiquei desempregada, eu fazia questão de não abaixar a cabeça para nada que ferisse meus princípios, mas baixei muito meu preço e abri mão de muitas noites de sono para cultivar pessoas que acabaram sendo essenciais para as conquistas que vieram depois. Você alcançou seu objetivo com 29 anos, enquanto eu, aos 24, já estava mais do que realizada. Mas, enfim, vai saber, né? Talvez tenha sido por não amolecer que conseguiu o respeito que tem até hoje de muitos outros artistas, profissionais da indústria discográfica e até de jornalistas. Falando agora como jornalista, eu acho que você não nos respeita, mas eu mesma sou uma que tenho um respeito enorme por você.

Fico por aqui, na esperança de que essa mensagem derradeira te toque de alguma forma.

Atenciosamente,

Christina Fuscaldo 


\section{A nossa aproximação}

No fim de novembro de 2006, conheci Bruno Batista, diretor de marketing da gravadora Sony\&BMG. Alguém sugeriu que ele me desse uma carona em seu táxi do hotel onde participamos da entrevista coletiva com a nova formação da banda Mutantes, que lançava um disco com a participação de Zélia Duncan, para o aeroporto de Congonhas, em São Paulo. No carro, começamos a falar sobre nossos projetos e contei que, assim como aconteceu com Ana Maria Bahiana $^{15}$ em 1972, eu tinha sido convidada a produzir matérias para a nova edição brasileira da Rolling Stone, lançada em outubro daquele ano. Empolgado por estar conhecendo uma colaboradora no Rio de Janeiro da revista cuja redação ficava em São Paulo, ele deixou escapar que, junto à gravadora e à equipe de Zé Ramalho, ia começar a trabalhar no álbum que o paraibano lançaria em 2007. Não tive coragem de contar sobre minhas investidas, mas falei que era fã do cara. Começamos, juntos, a pensar na possibilidade de Bruno conseguir liberação do Zé para eu acompanhá-lo em um dia de gravação, para uma matéria sobre o novo disco. Mandei a sugestão de pauta, mas acabei não podendo fazer a matéria, já que os rumos dessa aproximação com Zé mudaram. Em janeiro de 2007, Bruno me ligou e disse que o próprio Zé Ramalho queria me convidar para participar da gravação de seu novo disco, "Parceria dos viajantes". Ele não adiantou o assunto, mas marcou um encontro comigo na produtora de Zé. Mal dormi na noite anterior. Chegando lá, o cantor me recebeu junto a Bruno e a Otto Guerra, seu empresário junto a Ernst Castro desde o final da década de 1990. Nervosa, mas mantendo a postura, ouvi Zé me perguntar se eu aceitaria preparar um roteiro e entrevistá-lo para seu novo DVD e se eu faria o release desse trabalho. "Claro que aceito", eu disse. Cheguei em casa feliz, apesar de ninguém ter tocado no assunto "biografia". Comecei a trabalhar na pauta.

15 Jornalista e escritora, Ana Maria Bahiana estreou no jornalismo musical como secretária da redação e crítica musical da primeira edição brasileira da revista Rolling Stone. 
Na semana seguinte, eu estava lá no estúdio, com ele. No meio da conversa, a equipe de vídeo pediu uma pausa para a troca de fitas. Olhei para Zé, buscando saber o que ele faria durante o intervalo, e fui surpreendida por suas palavras: "Christina, sobre aquela proposta..." A respiração deve ter durado um segundo, mas para mim foi uma eternidade. Deu tempo de eu sentir meu corpo gelando, tremendo, queimando. "Eu aceito! Quero que você escreva a minha biografia!" "Meu Deus!", gritei por dentro, ainda tentando me manter firme na mesma posição em que estava quando olhei para saber se ele sairia dali para beber água ou retocar a maquiagem. "Mas tenho uma condição", continuou ele, enquanto eu orava em pensamento. "Prefiro começar as entrevistas quando você fechar parceria com uma editora. Já aconteceu de eu perder muito tempo com pessoas que prometiam escrever minha biografia e fizeram livros que não contavam minha história", falou. "Tenho certeza de que todas as editoras vão querer a sua história. E tenho certeza de que não irá se arrepender", disse a ele. Menos de um mês depois, enviei um e-mail para o endereço eletrônico que ele me deu e mostrei que, depois da última carta, eu era capaz de usar outro tom:

\author{
De: Christina Fuscaldo \\ Para: Ze Ramalho \\ Enviada: Segunda-feira, 12 de Fevereiro de $200721: 27$ \\ Assunto: Oi, Zé!
}

\title{
Oi, Zé!
}

Eu queria saber em que pé está o disco e se já tens mais detalhes sobre o processo para que eu possa ir juntando material para o release. Se puder, me fale também se vai rolar aquela sua apresentação ao lado de Daniela Mercury no carnaval de Salvador. Talvez eu esteja lá, fazendo uma cobertura para o jornal Extra.

Sobre o livro, já estou começando a correr atrás. Algo me diz que ele vai acontecer.

Um beijo da jornalista e fã,

Chris Fuscaldo 


\section{Meu arquivo em forma de projeto}

Eu fui para o carnaval de Salvador, onde tinha estado outras duas vezes, sempre a trabalho, mas não deu tempo de me deslocar dos pontos de cobertura para ver Zé Ramalho em cima do trio de Daniela. Outras duas capitais nordestinas que conheci no período em que trabalhei no Extra foram Fortaleza e Natal. Paraíba ainda era um sonho. E eu passei o resto de 2007 sonhando e preparando um projeto, que não poderia mais ser escrito à mão. Com minha mudança, em julho, para O Globo Online, fiquei mais esperta com a tecnologia, aprendi a usar uma ferramenta nova no computador e juntei fotos com textos sobre Zé Ramalho, sobre mim e sobre a estratégia de lançamento da biografia. Procurei listar os acontecimentos mais importantes da vida do artista e os nomes que não poderia deixar de entrevistar, seguindo as ideias de Peter Berger: eu também não queria experimentar a sensação de perder tempo com "grandes embates emocionais do passado não foram senão gozos pueris" (BERGER, 1983, p.69). A produção por mim de uma matéria para a Rolling Stone foi inviabilizada porque, a essa altura, eu já estava demasiadamente envolvida com o personagem e com seu novo trabalho, tornando qualquer escrita parcial. Não me importei, eu só pensava no livro. Minha meta para 2008 era descobrir qual seria a editora mais interessante e mais interessada e atacar. $O$ trabalho pesado viria depois, afinal, eu havia combinado com meu futuro biografado que, após a assinatura do contrato com a editora, faria entrevistas com os membros de sua família na Paraíba, os amigos de infância e adolescência, as mulheres de sua vida e os parceiros musicais, patrões e empregados com os quais trabalhou. Eu queria fazer o exercício de verificabilidade para escrever uma história que se aproximasse ao máximo da realidade. Eu não queria ser um dos narradores "que inventan historias que transcurren en alguno de los mundos conocidos, hay otros que inventan mundos, en los que pueden o no transcurrir historias." (GIORDANO, 2006, p. 55) 
E, de repente, Zé Ramalho ficou mais acessível. Ou talvez mais próximo. Talvez não fosse nada disso, mas eu me sentia mais íntima. A resposta desse e-mail que enviei veio com um pedido para que eu the telefonasse para saber das novidades. No dia seguinte, liguei e ouvi ele me dizer que queria muito me contar que havia

Peleja, vida e obra de

Zé Ramalho

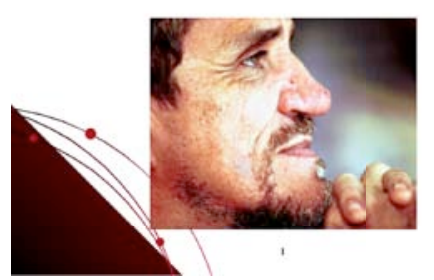
convidado para participar de "Parceria dos viajantes", entre outras cantoras, uma artista que eu admirava muito, a Zélia Duncan. Zé já estava compartilhando comigo o meu gosto musical! Como fiquei feliz... Que sensação deliciosa experimentei durante aquele ano! Era como se eu estivesse muito perto de realizar um grande sonho, mas já vivendo parte dele. Sim, porque posso dizer que foi incrível ter a chance de entrevistar Zé Ramalho assim, eu e ele, sem filtros ou regras que não fossem as nossas, sem as amarras da redação e de uma linha editorial e sem a vigilância de uma assessora de imprensa. E, mais ou menos no meio do ano, ficou claro que ele também tinha gostado. Tanto que, tardiamente, mas ainda em tempo, Zé me mandou através de Roberta Ramalho, sua terceira esposa e uma mulher mais adepta à tecnologia do que ele, uma mensagem na qual trazia à pauta o presente que dei a ele meses antes:

\author{
De: Roberta Ramalho \\ Para: Christina Fuscaldo \\ Enviadas: Quinta-feira, 14 de Junho de 2007 22:07 \\ Assunto: re-agradece
}

Olá, Christina.

Desculpe a demora para agradecer o presente que você me enviou. Valeu. $O$ boneco completa uma coleção valiosa. Obrigado mais uma vez pela atenção carinhosa.

Zé Ramalho 


\title{
13 A busca por uma editora e mais uma parceria
}

Dois mil e sete foi um ano atribulado. Depois do lançamento do CD e do DVD "Parceria dos viajantes", da morte do meu tio e padrinho após um ano lutando contra um câncer, da fase da readaptação no site do jornal O Globo, de uma viagem para um curso de um mês na Itália com uma bolsa que ganhei do consulado italiano (e com as passagens emitidas após ganhar um prêmio em $\mathrm{O}$ Globo Online) e de um período cuidando do meu namorado que chegou à mesa de cirurgia devido a um problema renal, consegui finalmente começar a corrida por uma empresa que quisesse apostar no meu livro. Ainda no primeiro semestre de 2008, após escolher a editora que achava ideal, enviei o projeto. Mandei um e-mail para Zé Ramalho, copiando sua esposa, acreditando que seria interessante que ele pudesse acompanhar mais de perto o processo:

\author{
De: Christina Fuscaldo \\ Para: Zee Ramalho; Roberta Ramalho \\ Enviadas: Sábado, 12 de Julho de 2008 18:23 \\ Assunto: Bob Dylan / livro
}

\section{Oi, Zé! Oi, Roberta!}

Em primeiro lugar, quero dizer que

adorei encontrar você, Zée, e conhecer você,

Roberta, e seus filhos na última terça-feira. 0

evento foi bacana, não é? Escrevo para passar a foto que fizemos juntos, para enviar os links dos vídeos do tributo a Bob Dylan

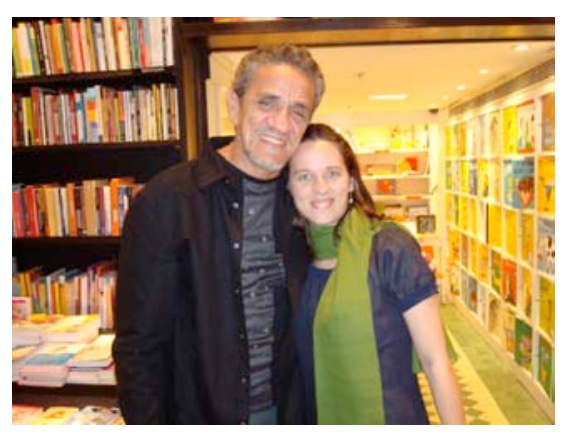
que você queria ver e para dar uma posição sobre a biografia. 
Comecei a fazer o projeto em meados de 2007, mas tive uma série de problemas e só pude acabá-lo pouco depois do carnaval. Mas, como depois da tempestade vem a bonança, o sol voltou a brihar em 2008. O projeto está nas mãos do editor da Agir, um dos selos de uma das maiores editoras do país, a Ediouro. 0 processo de decisão é um pouco demorado, já que ele precisa levar a ideia ao conselho editorial, que, alem dos editores de outros selos é assistido pelo dono da empresa. Haverá uma dessas reuniões ainda este mês e ele me disse que a resposta virá até 0 início de agosto. Pode ser que eles curtam o projeto, mas também pode acontecer de eles acharem que a biografia não tem o perfil desta editora. Aí, sigo com a peregrinação, que começou assim que o projeto ficou pronto: a editora Objetiva, por exemplo, não comprou o projeto, porque não costuma lançar biografias de brasileiros la do Tim Maia saiu por lá porque foi escrita pelo "influente" Nelson Motta). Enfim, queria te dar uma posição. E espero ter boas notícias em breve.

Sobre o tributo a Bob Dylan, fizemos um show, uma espécie de ensaio geral, em um bar de Olaria, na Zona Norte do Rio. O primeiro vídeo foi gravado lá e mostra um número em que brinquei de imitar Joan Baez. Depois, fizemos o show oficial, no Cinemathèque, em Botafogo. Este vídeo que está aí embaixo, da banda interpretando "Mr. Tambourine man", foi gravado lá. Só que você só vai me ver dobrando a voz e tocando violão, porque o vocalista, neste número, foi Fernando Duarte, correspondente do jornal O Globo em Londres. Não sei se viu na nossa newsletter de divulgação ou se ouviu dizer, mas essa banda é formada só por jornalistas e foi uma ideia do meu amigo e parceiro Leandro Souto Maior, guitarrista e funcionário do jornal O Dia. A Mariana Dantas, tecladista, é freelancer e, para tocar bateria, acabamos convidando meu irmão, Felipe Melo, porque não encontramos um bom baterista no nosso meio. Espero que se divirta. Para nós, foi uma grande brincadeira.

Beijos,

Chris 
Eu havia encontrado parte da família Ramalho - Zé, Roberta e os dois filhos mais novos, José e Linda - na Livraria da Travessa, no Shopping Leblon, na noite de autógrafos pelo lançamento do CD "Zé Ramalho da Paraíba"16. O disco duplo traz canções e discursos gravados durante aqueles shows que Zé fez antes de sair de seu estado natal, em 1976. Lá, após me dar um autógrafo e posar para mais uma foto comigo, ele comentou que tinha visto meu e-mail divulgando o show do Press Play Dylan e que tinha ficado muito curioso. O show na Zona Sul do Rio aconteceu em 16 de abril de 2008 e foi muito divertido. Ingênua, comentei com ele que Otto, seu empresário, tinha ido. Como se ele não soubesse... Depois, acabei me dando conta de que ambos já estavam bem intencionados em relação a mim. Zé, junto a Otto, preparava-se para me dar mais uma chance de aproximação: ele me convidou para escrever mais um release e para fazer um roteiro de entrevistas com alguns dos compositores das versões das canções de Bob Dylan que gravou no disco tributo ao compositor estadunidense, "Tá tudo mudado - Zé Ramalho canta Bob Dylan".

$\mathrm{Na}$ época, eu trabalhava como repórter de cultura do Globo Online, tentava terminar a faculdade de Letras e experimentava fazer parte de duas bandas, uma delas a ECT (Eu, Chris e Taís), dedicada à música brasileira e com repertório autoral (não meu, porque eu não compunha, mas de uma amiga muito talentosa chamada Taís Salles e do baiano multi-

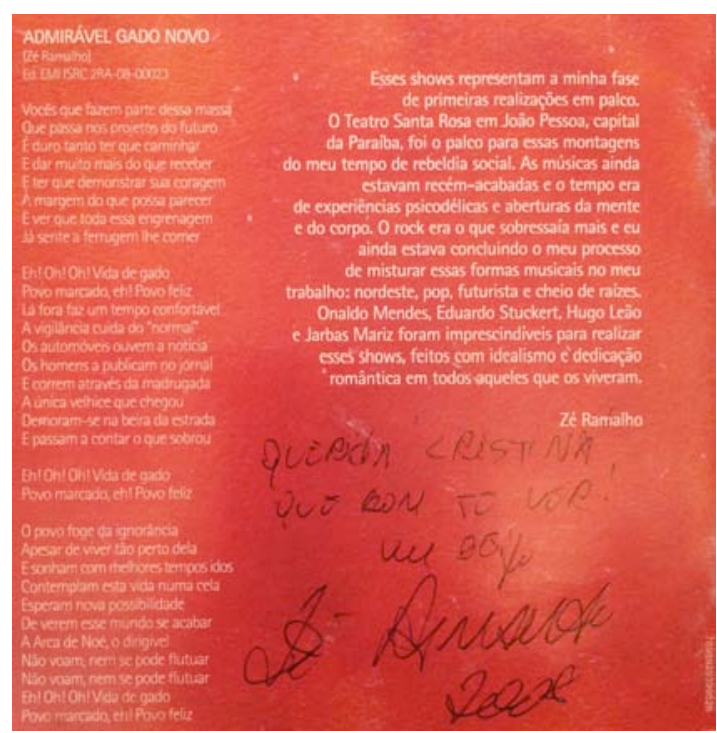
instrumentista Rodrigo Sestrem), e essa outra, formada por jornalistas e dedicada a fazer tributos. Animados com a vinda de Bob Dylan ao Brasil para seis apresentações, sendo uma no Rio de Discobertas, com raridades garimpadas no acervo do artista. 
Janeiro, nós da Press Play montamos um show em homenagem ao bardo ${ }^{17}$. Zé Ramalho soube, constatou que eu era tão fã de Dylan quanto ele - apelidado em 1978 por Nelson Motta de "Bob Dylan do Sertão" - e me convidou para fazer parte de seu novo projeto. Nesta conversa com os compositores Babal Galvão, Bráulio Tavares e Maurício Baia, incluída nos extras do DVD, eu apareço. Foi a primeira vez que minha imagem no comando de uma mesa redonda foi registrada e confesso que fiquei me achando feia, pouco feminina. Mas é claro que adorei a experiência, principalmente por ela estar diretamente ligada a Zé Ramalho, que acabou me chamando também para entrar na foto da capa do seu novo trabalho, inspirada no clipe "Subterranean homesick blues", de Dylan. Fiz par com Maurício Baia, músico responsável por duas das versões, sendo uma delas a que dá nome ao disco: "Things have changed" virou "Tá tudo mudando" nas mãos de Baia e Gabriel Moura. Incorporamos os papéis de Allain Ginsberg, o escritor e poeta beatnick, e Bob Neuwirth, músico da cena folk norteamericana. No vídeo, em uma rua escura e repleta de andaimes, Robert Allen Zimmerman (o Dylan) vai passando cartazes com frases enquanto a dupla de artistas conversa ao fundo. Na foto da capa do CD e do DVD, Zé segura um cartaz com o nome do disco enquanto eu e Baia simulamos o bate papo.
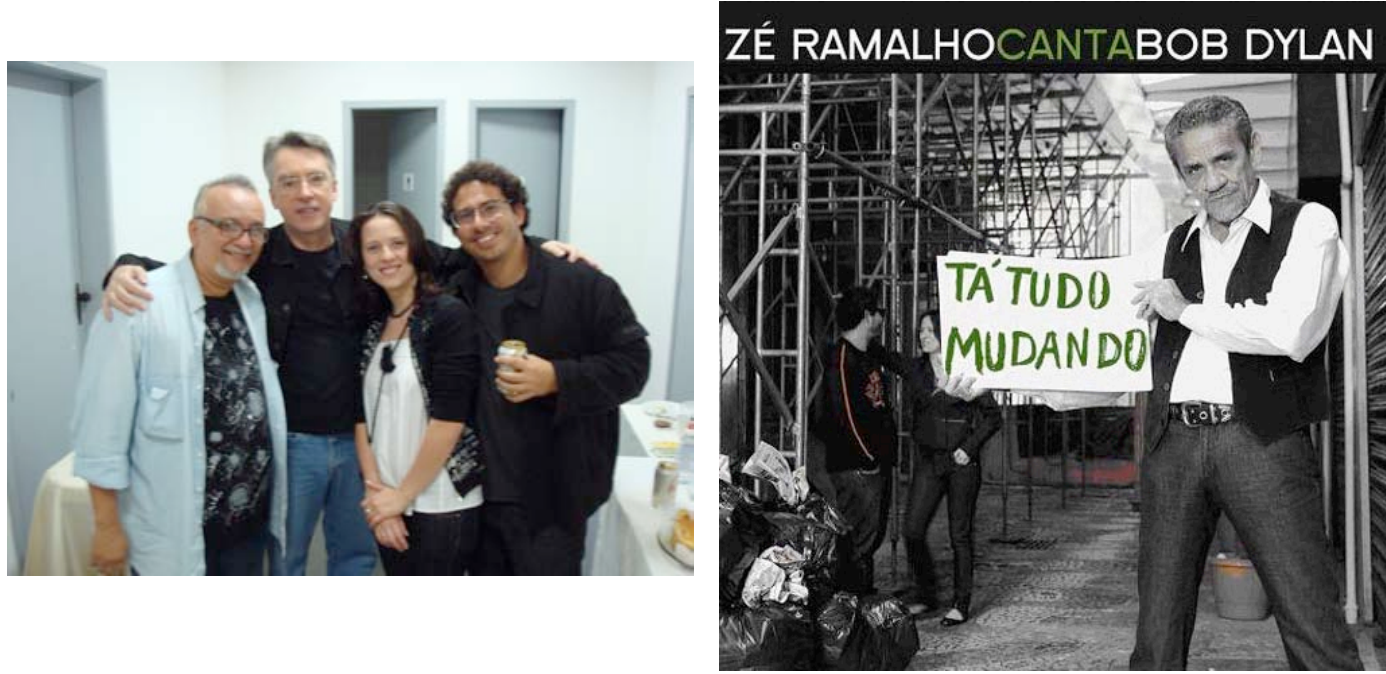

17 Um dos apelidos de Bob Dylan, "bardo" era a pessoa encarregada de transmitir mitos e lendas de forma oral, cantando as histórias do seu povo em poemas recitados. Era simultaneamente músico e poeta e, mais tarde, seria designado de trovador. 


\title{
14 Um caso rápido com uma editora interessada
}

Enquanto participava do projeto "Tá tudo mudando - Zé Ramalho canta Bob Dylan", que seria lançado em dezembro, eu marcava meu primeiro encontro com o editor da Agir: ele tinha ficado muito interessado na história de Zé Ramalho. No café da Livraria da Travessa do Leblon, além de contar mais casos sobre a vida e a obra do músico, expliquei a ele o formato que queria dar ao livro: "Não quero fazer um livro chapa branca e Zé sabe disso". Pensando numa pesquisa também etnográfica, disse que me propunha a ir até a Paraíba e a Pernambuco para aprofundar meu conhecimentos. "A vida dele parece uma obra de ficção, mas eu preciso apurar as passagens para não cair em ciladas", expliquei, afinal, "a tarefa do biógrafo, como a do jornalista, é satisfazer a curiosidade dos leitores e não demarcar seus limites" (MALCOLM, 1994, p.17). O editor sorriu e, ali no café, combinou que, com a autorização do Zé, fecharíamos o contrato. Saí comemorando, mas a minha felicidade não durou um mês. Enquanto o editor acompanhava de perto a Feira do Livro de Frankfurt ${ }^{18}$, eu redigia e pedia a Zé para assinar o documento que dava a mim o direito de escrever a sua biografia. Quando voltou de viagem, Paulo trouxe a má notícia:

\author{
De: Paulo Roberto \\ Para: Christina Fuscaldo \\ Enviadas: Quarta-feira, 29 de Outubro de 2008 16:25 \\ Assunto: Notícias não boas, infelizmente
}

Teu e-mail com a autorização para o Zé Ramalho me pegou numa hora ruim de uma semana especialmente difícil, na volta de Frankfurt. Vou ser direto no assunto: decidimos não ir em

18 A Feira do Livro de Frankfurt não sucumbiu a crise e teve recorde de público em 2008. Segundo matéria publicada no site DW, impulso pode ter sido dado pela "onda da digitalização": JÚLIA CARNEIRO. Feira do Livro de Frankfurt termina com recorde de público. Disponível em http://www.dw.de/feira-do-livro-de-frankfurt-termina-com-recorde-de-p\%C3\%BAblico/a-3727600-1? maca=bra-uol-eco-1394-xml-uol. Acesso em 02/07/2013. 
frente com o projeto. Não tenho, evidentemente, nenhum prazer em te comunicar isso - e muito menos em ter participado da decisão. Mas o fato é que o caos financeiro internacional faz suas marolas - e consideráveis - aqui no nosso mercado. O que a bio do Zé tem a ver com isso? Nada e tudo. Pois a partir desta nova perspectiva financeira, já que temos muitos adiantamentos em dólares, bem como a prestação de contas destes royalties, tivemos que repensar 2009. E, no novo cenário, teu liuro fica complicado. Explico: naqueles termos propostos, o projeto fica inviável financeiramente (mas isso poderíamos negociar, é claro). E, o que é mais importante, com a quantidade de livros que lançaremos (reduzida), o livro do Zé não teria o esforço de promoção necessário para que dê realmente certo. Não se trata, é claro, de um dia acreditar numa coisa e noutro não acreditar por conta de oscilações financeiras - o projeto é bom de qualquer jeito, continuo achando, mas, em termos diretos, deixou de ser prioridade aqui dentro. Ou seja, não faz sentido o nosso investimento se não podemos seguir conforme o combinado. Poderia te dizer que, mais pra frente, as coisas podem mudar e a gente mudar de ideia - o que, efetivamente, pode até acontecer. Mas, pelos motivos óbvios, você tem é que estar livre para procurar outra editora. Eu gostei da ideia e mais ainda de nossa conversa, mas vamos ter que adiar um trabalho em conjunto para uma próxima. Eu realmente lamento a decisão, mas infelizmente assim que teve que ser feito.

Chorei muito e ainda levei uma bronca do meu pai, que me ligou logo após eu ler o e-mail de Paulo. "Para que chorar assim? Até parece que perdeu alguém da família!" Desliguei mais triste ainda e, por incentivo de minha parceira Taís, naquele mesmo dia, fui fazer o meu mapa astral com uma alemã que, além de mãe de santo em seu terreiro de umbanda, entende muito de astrologia. Kiti entrou para o grupo no qual me apoiava quando eu mesma não conseguia me ajudar e do qual fazia parte Andree, terapeuta com quem vinha me consultando semanalmente desde 2004. As duas me viram chorar e sorrir muito, só que Kiti, uma vez por ano. Naquele momento, achei que os astros me ajudariam a pensar em que caminho seguir. A leitura daquelas linhas me acalmou e também me estimou a insistir. Decidi, então, escrever uma carta para Paulo. 
Rio de Janeiro, 30 de outubro de 2008.

Caro Paulo,

Recebi o seu e-mail ontem pela manhã e passei o resto do dia pensando sobre o que li.

Entendi que o que te fez suspender a nossa negociação é uma questão econômica, de mercado, e não artística. Mas fiquei com a sensação de que eu não podia simplesmente responder com um "ok", agradecendo pela explicação. Senti uma necessidade grande de te escrever para tentar uma chance de reverter esse quadro. Você acha mesmo que não há negociação? Estou com a declaração assinada por Zé Ramalho e não queria ter que dar essa notícia a ele e muito menos perder - tão em cima da hora - a chance de aproveitar aquele gancho dos 60 anos, que ele completa daqui a um ano. Para que sinta como estou adiantada nesse processo de escrita, envio aqui mesmo nesta esta carta, logo aí embaixo, um capítulo da biografia. Espero que goste!

\section{O primeiro disco, a morte de Avôhai e a chegada no Rio}

Para Zé, 1976 foi intenso. Se no ano anterior, ele gravou seu primeiro disco e viveu a experiência de tocar fora do Nordeste pela primeira vez, agora planejava alçar-se sozinho no mercado do Sudeste, onde havia mais oportunidades para artistas em geral. Mas, antes de embarcar de vez para o Rio, onde se instalaria, sofreria, mas conseguiria alcançar seus objetivos, muita coisa aconteceu em João Pessoa, inclusive a morte de seu avô e pai, o Avôhai. José Alves Ramalho sofria de pressão alta e não viu o sucesso chegar para o neto querido, que em 1972 abandonou a faculdade de Medicina para mergulhar de vez na música.

Além de lançar com Lula Côrtes o álbum "Paêbirú - Caminho da montanha do sol", em 1975, Zé Ramalho embarcou, acompanhando Alceu 
Valença no show "Vou danado pra Catende", para o Rio de Janeiro. Único paraibano entre os pernambucanos que tocavam na banda de Alceu, Zé Ramalho da Paraíba, como era chamado, destacava-se por ser um exímio violeiro. Mas ele tinha algo a mais... algo que ia além da postura, da voz diferenciada e do talento para compor uma música diferente de tudo o que havia no mercado: Zé tinha um brilho diferente. Em um Fusca vermelho, viajou com Alceu para o Rio, onde assumiu o violão de 12 cordas, a viola de 10 e o ukulelê no show do pernambucano.

Zé e Alceu se conheceram em Pernambuco, em 1973: a namorada de um era irmã da namorada do outro. A essa altura, The Gentlemen já era uma banda famosa, tinha atravessado a fronteira que dividia a Paraíba dos estados vizinhos e apresentava-se com frequência nos bailes de Recife, que fica a menos de duas horas de viagem de João Pessoa. Desde que saiu de Brejo do Cruz, dona Estelita Torres Ramalho morava com a filha, Maria Goretti Ramalho, na capital pernambucana e era na casa da mãe e da irmã que Zé pousava quando queria aproveitar melhor a cidade. Foi durante essas passagens que Zé começou a se enturmar com um grupo de artistas que despontavam em Recife e acabaram responsáveis pela formação de uma cena. Faziam parte dela o casal Lula Côrtes e Kátia Mesel - ambos artistas plásticos, só que, além disso, ele era músico e ela, cineasta - que moravam em um casarão no bairro de Casa Forte que um dia fora uma senzala. Junto a outros, Zé passava horas fumando maconha e experimentando outras drogas, tocando com Lula e admirando as criações de Kátia. Animados com a abertura para a gravação de projetos alternativos pela Rozenblit, uma das maiores produtoras de discos do Brasil, sediada na capital pernambucana, e com o empurrãozinho dado pelo pai de Kátia, o professor Mesel, reitor da Universidade da Paraíba que era amigo do dono da gravadora, o também judeu José Rozenblit, surgiu a ideia de se gravar um álbum. Zé apresentou à Lula a Pedra do Ingá - que ele já conhecia das viagens que andou fazendo pelas cidades do interior da Paraíba em busca de suas raízes sertanejas - e, admirando o monumento arqueológico, embalados por muito chá de cogumelo e maconha, a dupla criou sons e letras nada convencionais, que ganharam 
toques mais alternativos ainda quando, dentro dos estúdios da Rozemblit, os outros parceiros da cena entraram para gravar. Um deles foi Alceu, que na época já se organizava para levar seu show para o "Sul" (como eles chamavam todas as regiões que estavam abaixo do Nordeste).

Alceu misturava frevo e forró com o rock disseminado no Brasil pela Tropicália e pela Jovem Guarda. Em 1972, gravou com Geraldo o álbum "Quadrafônico" pela gravadora Copacabana, com canções próprias. Em 1974, a mesma dupla foi convidada a participar da série Disco de Bolso, do Pasquim, ao lado de Sérgio Ricardo, mas o projeto desandou e Sérgio, encantado com a imagem de Alceu, convidou o músico para assumir o papel principal no filme "A noite do espantalho", que ele iria rodar em Nova Jerusalém, no sertão de Pernambuco. Além de fazer o espantalho, Alceu gravou voz com Geraldo, Sérgio e outros músicos para a trilha sonora. Após ser visto em um dos shows que fez em Recife por um produtor da TV Globo Nordeste, foi contratado pela Som Livre e gravou seu primeiro disco solo, "Molhado de suor", no mesmo ano. Pouco depois, ao classificar "Vou danado pra Catende" no Festival Abertura, da TV Globo, montou uma banda com Lula Côrtes (tricórdio), Zé Ramalho (viola), Paulo Rafael e Ivson Wanderley (guitarras), Israel Semente e Agrício (percussões) e Zé da Flauta (flauta). Por não conseguir enquadrar o som que apresentaram no festival, em janeiro de 1975, o júri criou uma categoria de última hora chamada Incentivo à Pesquisa para poder premiar o grupo. "Vou danado pra Catende" virou uma faixa da segunda tiragem do álbum "Molhado de suor" e um show. Na chegada ao Rio, ao saber que não tinham sido vendidos muitos dos ingressos disponíveis na bilheteria do Teatro Tereza Rachel, Alceu convocou os músicos da banda para saírem às ruas, com megafone feito de papel, chamando público. Com corpo de roqueiro, alma de repentista e voz de trovador, em "Vou danado pra Catende", Zé cantava uma composição de sua autoria chamada "Jacarepaguá Blues" em um momento em que o anfitrião saía do palco. Em uma das noites, Zé tomou um LSD junto a Paulo Rafael e, sob efeito da droga, cantou uma música diferente da combinada: "Vila do Sossego". Alceu Valença não gostou da mudança no roteiro, os dois discutiram no camarim e, na volta para o 
palco, Zé quebrou a viola do pernambucano, avisando ao público que fazia uma homenagem a Sérgio Ricardo, compositor que, ao ser vaiado enquanto cantava "Beto bom de bola" no III Festival de Música Popular Brasileira, transmitido pela TV Record em 1967, irritou-se, quebrou o violão e atirou o instrumento contra a plateia. As pessoas da plateia aplaudiram, acreditando fazer parte do espetáculo. Zé voltou para João Pessoa e passou o resto de 1975 e o início de 1976 planejando o seu retorno para onde tudo acontecia.

José Alves Ramalho morreu em 22 de maio de 1976. No dia 26, Zé subia ao palco do Teatro Santa Rosa para participar da Coletiva de Música da Paraíba, um evento organizado pelo agitador cultural Pedro Osmar que dividiu em cinco noites 20 expoentes da cena paraibana. Zé foi o primeiro a tocar e escandalizou. Já conhecido por ter feito o primeiro show de rock da Paraíba em maio de 1974, intitulado "Atlântida" - influenciado pelo filme Woodstock e, em especial, pela canção "Atlantis", de Donovan, o espetáculo foi apresentado por Zé Ramalho junto à banda Filhos de Jacó, de Jarbas Mariz -, o artista sabia que ali não era mais o seu lugar. Pintado ao estilo Secos \& Molhados e Kiss, apresentou músicas próprias, fez discursos contra a recepção local à sua música, contra os críticos de arte da Paraíba e contra o high society que, segundo ele, tinha preconceito contra os "hippies". Não satisfeito, quebrou uma televisão e cortou a cabeleira black power no palco citando Sansão - mas sem perder seu poder de prender a atenção do público. "Esse trabalho da Coletiva soa muito bem pra mim pela qualidade e pela honestidade que ele oferece. $O$ bloqueio que os artistas paraibanos que fazem música sofrem pelas diversas camadas que cobrem a cidade, as camadas sociais, as camadas políticas, as camadas astrais, cósmicas e outra bulhufas. (...) Já era tempo de todos acordarem para os ciganos. Defino eles como ciganos, tachados de marginais, de maconheiros, repudiados onde quer que entrem, criticados pelos cabelos que nós usamos, pelas nossas roupas que são bonitas e coloridas. Apenas enchemos a vida de mais flores e essa Coletiva está fazendo exatamente isso, firmando um lugar conquistado como se conquista as bandeiras, os bandeirantes. O lugar do músico 
paraibano existe. Existe e foi criado na coragem, no idealismo. Essa Coletiva foi muito pouco apoiada, muito pouco apoiada. A própria imprensa se autorizou a falar nos jornais de hoje apenas uma transação pedida. Sempre tem que ser pedida, todo mundo acha que está fazendo favor: 'Ah, bota uma notinha desses caras aí no jornal'. Que favor estão fazendo a nós que estamos aqui trabalhando? É o nosso trabalho", reclamou Zé. "A crítica a um movimento musical, a crítica a uma música, um trabalho de arte... Lanço aqui mais um manifesto para encontros críticos, contra qualquer crítica. Sou a favor... Sou a favor do comentário e não da crítica. (...) Críticos são parasitas que se arrastam em cima do trabalho dos outros... O trabalho honesto. A gente passa o dia inteiro, o ano inteiro, a vida inteira trabalhando em músicas, compondo, fazendo letras, arranjando pra um fulaninho que tá deitado em casa tomando água e refresco (...) Para ele receber um convite para vir assistir ao show e dizer se é bom ou ruim. Mas quem tem que dizer isso é o público, quem tem que dizer isso é vocês! Porque na verdade vocês não precisariam de nada disso. Vocês é que são os próprios juízes e sabem o que é bom ou ruim. Vocês têm ouvidos e são inteligentes! Por que é que o crítico vive no país? (...) Bando de otários e imbecis. Eu desafio qualquer critico a tocar uma música, a ter uma sensibilidade musical", bradou o músico, exaltado.

Paulo Rafael lembra que tomou um susto quando chegou e viu aqueles instrumentos nada comuns. "Peguei um ônibus de Recife para João Pessoa e cheguei lá umas sete horas da noite. Quando fui até o palco para colocar minha viola, tinha quatro bancos, um para eu sentar, outro para ele, um com uma televisão Philco pequena e o outro com uma bandeja com uma tesoura e um punhal enorme. Dei um pulo, fui para o camarim e perguntei: 'Que porra é essa, Zé? Vai me matar no palco?' Ele já estava com uma maquiagem muito bem feita, uma roupa muito louca $e$ uma bota com um salto alto pra caramba. Zé era esquelético e ficou uma figura esquisita, mas interessante. Ele sempre foi muito cuidadoso com a parte teatral do show. Ele me disse, então, que era para eu ficar tranquilo e ir tocando que, no meio do show, iam rolar umas coisas. E lá pelas tantas, chutou a televisão, que saiu quicando, mas não se abriu. Eu só pensava 
que, se aquilo explodisse, ia ser uma loucura. Depois, cortou os cabelos. O povo não entendia nada, mas vibrava. No final, Zé mandou eu sair, fez um discurso esculhambando João Pessoa e as pessoas de lá, colocou a viola no chão e se ajoelhou para, como se imolasse um cordeiro, sacrificála com o punhal, que atravessou até o piso de madeira do teatro. Quando acabou o show, saímos para comemorar".

A homenagem ao avô foi o momento mais emocionante do show. "Essa música que nós vamos tocar é muito especial para mim. Permitamme abusar disso. Mas é que, há três dias atrás, faleceu meu avô, talvez a única criatura honesta que eu tenha conhecido no mundo. Foi ele que me criou, saindo do sertão, do Brejo. Eu nunca tive pai. Então, vovô fez o papel de avô, de pai e, antes de morrer, fez o papel de filho também pra mim. Avôhai é uma palavra mágica. Avôhai significa avô e pai. Vovô, esteja em paz. Quando penso que você está aqui, tenho certeza que você está me olhando aqui, talvez aqui no meio de todos. Avôhai!", declarou Zé antes de tocar a música que é até hoje o seu maior sucesso.

Houve ainda um grande show em João Pessoa antes de ele ir para o Rio: no dia 10 de setembro de 1976, no Teatro Santa Rosa, com o cabelo mais curto, Zé Ramalho apresentou "Um dia antes da vida" acompanhado de Luiz Hugo Filho, Walmir Silva, Irapuan Neves e Edmilson Silva. No repertório, já estavam canções que figurariam o seu primeiro álbum, gravado só em 1978: "Meninas de Albarã", "Jardim das acácias", "Avôhai", "Adeus segunda-feira cinzenta", "Chão de giz" e "Vila do Sossego". Pronto para viajar e correr atrás de seu objetivo, o artista ainda rodou cidades do interior da Paraíba e, em novembro, poucos dias depois do aniversário da avó Soledade, comemorados no dia 23, já com 27 anos, Zé Ramalho (não mais carregando como apelido o "da Paraíba") foi embora jurando, com todo orgulho que um nordestino pode ser capaz de ter, que, se seus planos não dessem certo, ele nunca mais voltaria a seu Estado natal.

Um abraço,

Chris Fuscaldo 


\section{As consequências de um mercado editorial em crise}

Meu esforço foi em vão. Paulo pediu desculpas e se ofereceu para me ajudar, indicando outras editoras e recomendando meu nome aos responsáveis por elas. Mas, se uma das maiores empresas do ramo do país estava em crise, imagine as outras? E foi como eu previ: tanto no final de 2008 quanto em 2009, nenhuma editora sequer se propôs a ler meu projeto. $O$ motivo era sempre o mesmo: a crise financeira que assolava 0 mundo ${ }^{19}$. O problema ainda foi agravado pela briga na justiça iniciada pelo cantor Roberto Carlos ${ }^{20}$ em 2007, que resultou no recolhimento de mais de 10 mil exemplares da biografia não autorizada Roberto Carlos em detalhes, escrita pelo historiador Paulo César de Araújo e publicada no ano anterior pela editora Planeta. Aproveitando-se da brecha que os advogados do artista encontraram no artigo 20 do Código Civil ${ }^{21}$ para proibir a escrita não autorizada sobre ele, muitos outros nomes citados em biografias resolveram também cobrar o direito de não querer sua identidade exposta em livros. Considerado absurdo pela mídia e até por outros artistas Guarabyra chegou a fazer um documento que proíbe seus herdeiros de censurarem citações sobre o músico em biografias ${ }^{22}$-, o episódio levantou uma discussão sobre a importância e 0 desrespeito com 0 trabalho dos

19 Dizia-se que a crise financeira de 2008, iniciada nos Estados Unidos após o estouro da bolha especulativa no mercado imobiliário, foi a maior da história do capitalismo desde a grande depressão de 1929. PIRES E BALIEIRO, Fabiana e Silvia. O mundo depois da crise de 2008. Disponível em <http://epocanegocios.globo.com/Informacao/Visao/noticia/2013/09/o-mundodepois-da-crise-de-2008.html>. Acesso em: 20 mar. 2015.

20 TIAGO DIAS. Processado por Roberto Carlos em 1983, Ruy Castro diz que lei e "vaidade sem limites" limitam Disponível em http://entretenimento.uol.com.br/noticias/redacao/2013/04/25/processado-por-roberto-carlos-ruycastro-diz-que-lei-e-vaidade-sem-limites-limitam-livros.htm. Acesso em 25/04/2013.

21 Artigo 20 do Código Civil: "Salvo se autorizadas, ou se necessárias à administração da justiça ou à manutenção da ordem pública, a divulgação de escritos, a transmissão da palavra, ou a publicação, a exposição ou a utilização da imagem de uma pessoa poderão ser proibidas, a seu requerimento e sem prejuízo da indenização que couber, se lhe atingirem a honra, a boa fama ou a respeitabilidade, ou se se destinarem a fins comerciais."

22 RIBEIRO, Marcelle. Guarabyra - Músico que registrou documento que impede herdeiros de censurarem sua biografia prepara turnê comemorativa dos 40 anos do rock rural. Revista $\mathrm{O}$ Globo, Rio de Janeiro, 14 abr. 2013, p. 30. 
pesquisadores. Como repórter do Extra, eu participei da coletiva de imprensa em que, ao ser perguntado sobre o que achou da recém-lançada biografia, Roberto respondeu: "Não li e não gostei." Anos depois, o autor contou na autobiografia "O réu e o rei", que o juiz responsável pelo caso, que deu à Planeta a opção de aceitar o recolhimento dos livros ou assumir o risco de pagar uma conta alta, pediu autógrafo a Roberto Carlos, contou-Ihe que era cantor e presenteou o "Rei" com um disco seu. O caso me lembrou uma frase dita pelo personagem Graciliano Ramos, segundo Silviano Santiago, no livro Em liberdade:

(...) este país é uma bagunça geral. Nada aqui se sustenta dentro de uma ética rigorosa. É sempre um jogo de interesses vergonhoso, mesquinho e camuflado. $\mathrm{Na}$ esculhambação nacional, qualquer atitude lógica e coerente torna-se inapropriada. Em lugar de se beneficiar dela, a pessoa correta acaba por ser 0 único palhaço no carnaval geral da nação. (SANTIAGO, 2013, p. 143)

O livro é um registro histórico e, graças a minha avidez por biografias, consegui comprá-lo antes de o acordo ser firmado entre Roberto Carlos e a editora. Mas foi uma tristeza ver Paulo César, depois de 15 anos dedicando-se à pesquisa, virar o "palhaço". Fora ele, muitos outros escritores também foram prejudicados. As editoras começaram a acumular uma grande quantidade de processos e passou a não ser nada interessante correr o mesmo risco. Sendo eu uma escritora de primeira viagem, ficou ainda mais difícil convencer um publisher a apostar no meu projeto. Sobre essa questão, a luz no fim do túnel é o Projeto de Lei 393/2011, do deputado Alessandro Molon, do PT do Rio, já aprovado pela Comissão de Constituição e Justiça (CCJ) da Câmara, que autoriza a divulgação de imagens, escritos e informações biográficas de pessoas públicas, mesmo sem a autorização da pessoa ou de parentes do biografado. A proposta altera o artigo 20 do Código Civil para incluir a possibilidade de divulgação da biografia sem autorização quando a trajetória pessoal, artística ou profissional da pessoa tenha dimensão pública ou haja interesse da sociedade em sua divulgação. Mas, se o Projeto vai virar Lei, isso ainda é uma incógnita. 
Rio de Janeiro, 08 de abril de 2009.

Oi, Zé, tudo bem?

Escrevo por vários motivos. Primeiro, quero elogiar o CD/DVD "Tá tudo mudando Zé Ramalho canta Bob Dylan". Sempre me acho feia em fotos e vídeos, mas a edição dos extras do DVD ficou tão boa que não me incomodou. E a capa, que barato! Estou muito orgulhosa por estar ali, complementando uma cena que você escolheu interpretar. E logo de Bob Dylan, um dos meus maiores ídolos! Fora a parte que me toca, queria também elogiar as músicas. Adorei as versões e acredito que a recepção do público tende a ser maravilhosa, afinal, mesmo não sendo o cara mais acessivel deste Brasil, você tornou acessíveis as canções de Dylan, um artista que não é digerido tão facilmente por um ouvinte brasileiro e que também nunca foi o artista mais acessivel do showbusiness norte-americano. Já falamos muito sobre o projeto na entrevista que fiz com você para o release, mas desde que recebi o CD e o DUD - aliás, obrigada pelo envio também das camisetas com nossa foto da capa estampada nelas -, ando pensando em como seria se Dylan resolvesse gravar músicas suas. Nelson Motta me contou que, quando te comparou a Bob Dylan, pensou no jeito de cantar dos dois. Mas na fala dele, ficou bem claro que não era só isso, até porque ele mesmo diz - e era exatamente o que eu pensava - que você canta muito melhor que ele. Acredito que a cena musical na qual você apareceu inserido ajudou Nelson a formar essa ideia. Olha o que ele me disse: "Quando o Zé Ramalho apareceu, a grande novidade era seu grupo fazendo uma música nordestina elétrica pesada. O Gilberto Gil já tinha algumas experiências nesse sentido, assim como alguns outros, mas de uma forma mais organizada. Zé, Alceu, Fagner, esse pessoal veio com uma sonoridade realmente nova: eles conseguiram misturar o fraseado nordestino com a guitarra. Paulo Rafael, o guitarrista de Alceu, tirava um som de rabeca da guitarra sensacional. Virou um folk nordestino. Durante o show do Alceu, surgiu a brincadeira de chamar Zé Ramalho de Bob Dylan do Sertão por causa do timbre vocal, que não tinha nada a 
ver, porque Zé tinha uma voz melhor que a do Dylan. Não lembro se foi o grave que chamou minha atenção, mas ele foi praticando o canto falado e aí a presença de Dylan ficou mais forte."

Sempre fico curiosa para saber de onde vêm as influências dos artistas que curto. Acho que por isso as biografias me interessam tanto. Você já me disse, em entrevistas, que Beatles e Jovem Guarda surgiram na sua vida através da rádio, quando foi morar em João Pessoa, aos 13 anos. Eque as referências nordestinas, incluindo aí os repentes, cordéis e aboios, já estavam entranhadas desde que era pequeno, mas afloraram mais quando você foi em busca delas, em viagens pelas cidades do interior da Paraiba. E Bob Dylan? Transcrevi um depoimento seu do DVD em que diz que o que mais gostou em Robert Zimmerman foi sua rebeldia musical: "Me entusiasmei muito com essa referência que ele deu, de você fazer uma letra longa, fazer uma canção longa, botar uma melodia mais longa ainda, sem se importar com o estabelecido, o tempo que as rádios exigiam. E fui me afeiçoando à obra dele. Isso, ao lado de Beatles, ao lado de (Rolling) Stones, ao lado de Gonzagão, ao lado de Jackson do Pandeiro, ao lado dos cantadores... Eu tive vários mestres: Pink Floyd, Santana... Todos foram muito importantes pra mim por causa da junção que eu fiz com a música da minha região e com a música do meu país."

Essa sua fala me lembrou de um papo que tive com seu conterrâneo José Nêumanne Pinto, que em 1978 já endossava o apelido cunhado por Nelson Motta. Primeiro porque o jornalista contou que foi um dos primeiros paraibanos a conhecer Bob Dylan: "Eu tinha um amigo cujo irmão estudou nos Estados Unidos. Em 1967, ele chegou de viagem com dois discos do Bob Dylan, 'Bringing it all back home' e 'Highway 61 revisited'. E ele trouxe também uns discos da Joan Baez que tinha gravações do Bob Dylan. Eu me apaixonei perdidamente." Durante nossa conversa, lembramos de quando Joan Baez esteve no Brasil, em 1980, e, devido a suas atividades como ativista e militante pelos direitos humanos, foi proibida pela Polícia Federal de cantar com você, mas subiu ao palco e dançou enquanto você entoava "Admirável gado novo". O jornalista ainda fez uma análise sobre a mistura das influências em sua música: "Zé absorveu aquela coisa da guitarra e fez uma fusão. Eu acho que o grande segredo da boa música é a fusão." 
Parece que tanto o depoimento de Nelson quanto o de Nêumanne fazem sentido depois que vi outra fala sua no DVD: "O trabalho de alquimista, de reunir sons, de misturar, não importa se sempre dará certo ou se não vai dar certo. O importante é você procurar sempre estar misturando, nunca estar nem repetindo nem ao menos, sequer, você estar fazendo cover ou alguma coisa parecida. Então, todas essas influências desses ícones, junto com os ícones brasileiros de que eu já falei, Dylan talvez esteja lá em cima, pelo feeling, pelo jeito estranho dele cantar e pela emoção que ele me passa nas canções dele. Algumas que me fazem chorar até hoje! Eu escuto as canções dele com a mesma emoção que eu escutava quando eu era rapaz, quando eu tinha 23 ou 24 anos, que tocava guitarra lá em João Pessoa, na Paraíba." Zé, tu és um alquimista que se emociona com seus ídolos, assim como eu me emociono com os meus.

Ao mesmo tempo que em paro para te escrever essa carta, fico analisando o meu papel na sua vida desde o dia em que você me deu a autorização para escrever sua biografia. Acho tão maravilhoso esse exercício que os biógrafos fazem de tentar entender a vida de seu biografado, intercalando-a com o contexto histórico no qual ele viveu. Venho aprendendo bastante com um trabalho que fui convidada a fazer sobre a Legião Urbana. No Jornalismo, cada matéria que escrevo também me obriga a estudar melhor o contexto no qual o personagem que entrevisto está inserido. Sinto-me meio historiadora, mas, no seu caso, estou só começando a pesquisa, Zé. Nem sei se o que já escutei sobre você se aproxima da realidade. A verdade sobre os fatos, já percebi que nunca vou encontrar, mas estou empenhada em tentar chegar o mais perto possivel do que você viveu. Bom, mas eu queria falar sobre o livro.

Quando entrei novamente em contato com o editor da Agir para entregar aquela autorização que você me passou, ele pediu para que eu esperasse até 2009, porque a crise tinha pego a editora de jeito e todos os projetos (não assinados) haviam sido suspensos. Esperei para dar boas notícias, mas passou o carnaval e, até agora, não conseguimos fechar nada. Pior é que andei pesquisando e descobri todas as outras editoras grandes estão na mesma situação, esperando a crise passar. Fora isso, ainda houve essa confusão entre Roberto Carlos e o autor da 
biografia não autorizada dele. Não faz nem um ano que li, em uma matéria jornalística, que você e ele estavam do mesmo lado em uma briga contra a editora EMI Songs, que não liberou composições de vocês para discos gravados pela Sony/BMG. Sobre a questão da biografia, cada um pensa de um jeito. Ainda bem que não foi sobre ele que eu decidi escrever! Bom, o fato é que ando conversando com muita gente e pensando em alternativas (Livro patrocinado? Editora pequena? Início de pesquisa para entregar o projeto pronto à editora?), mas acho que o projeto vai ficar para 2010. Mas aí vem minha maior dúvida: você está disposto a esperar?

Aguardo um retorno, para saber se está tudo em ordem.

Abraços,

Chris Fuscaldo

Acompanhando cada passo que dei e a involução do processo, Zé me convidou a ir até a sua casa para me dar DVDs com entrevistas registradas para o documentário "Zé Ramalho - O herdeiro de Avôhai", dirigido pelo jornalista paraibano Elinaldo Rodrigues, textos com depoimentos seus e dois livros, ou melhor, dois projetos de biografia mal-sucedidas: "Zé Ramalho - O poeta dos abismos", de Henri Koliver, e "Zé Ramalho: Um visionário do século XX", de Luciane Alves. Enquanto eu olhava o conteúdo da sacola, Zé puxou um assunto delicado: "Você está assustada porque soube que outro jornalista quer escrever minha biografia. Isso aqui é para mostrar que ainda quero que você a escreva. Sei que esse é um projeto importante para você e que, para ele, seria só mais um livro". Fiquei aliviada, pois de fato senti medo e acabei desabafando com seu empresário, Otto, o que foi bom, pois a informação chegou aos ouvidos do meu biografado. "Jurei para mim olhar sempre as coisas com amor e procurar compreendê-las antes de as julgar." (ANDRADE, 2001, p. 47). 


\section{Outras biografias}

Assisti aos três DVDs que Zé Ramalho me deu e descobri quase seis horas de uma entrevista muito boa feita por Elinaldo Rodrigues para seu documentário, cuja produção começou em 2006 e o lançamento aconteceu em 2009. O "muito boa" refere-se também à atuação do entrevistado, afinal, o diretor destrincha diversos e interessantes temas da vida do artista, que aproveita muito bem o momento falando também sobre o que não lhe é perguntado. Tática que Zé deve ter aprendido ao longo dos anos com as muitas entrevistas ruins a que deve ter sido submetido. Achei muito bem abordado e editado o trecho sobre a iniciação profissional do protagonista, na Paraíba e em Pernambuco. As ótimas entrevistas de Onaldo Mendes e Eduardo Stucker - ex-empresário e ex-técnico de som da equipe de Zé que nunca falariam para meu livro por causa de um mal entendido entre Onaldo e o velho amigo - e de outros personagens que viveram a fase levam o espectador àquela época (mesmo os que não têm idade para isso, como eu). É lamentável que o filme não tenha conseguido abarcar melhor a volta por cima de Zé, quando ele supera sua crise pessoal e profissional e retoma a cadeira que ele deixou vaga durante o período em que mergulhou nas drogas. Fazem falta as entrevistas com Ísis e Amelinha, ex-esposas de Zé Ramalho, que viram ele começar a compor (a primeira) e alçando voo para o sucesso (a segunda). Acaba não fazendo sentido ter depoimentos de Christian, Antônio, José e Linda, os dois filhos mais velhos e os mais novos, e não ter os de João e Maria, os que ele teve com a cantora cearense. Depois que assisti ao filme, pensei: Será que Elinaldo fez o mesmo que uma das biógrafas de Sylvia Plath analisadas por Janet Malcolm? "O erro imperdoável de Anne Stevenson foi hesitar diante do buraco da fechadura" (MALCOLM, 1994, p. 17).

Stevenson não foi perdoada pelos leitores e pela crítica por não se aprofundar na narração de certos episódios. Ela escreveu em seu prefácio que toda biografia da poetisa deveria levar em consideração a vulnerabilidade de 
seus familiares ainda vivos. No caso de Elinaldo, talvez o problema tenha sido o medo das leis que podem ser utilizadas para a proibição de livros e filmes sobre personagens públicas, afinal, o cenário brasileiro é bem diferente daquele onde Malcolm e todos os biógrafos norte-americanos se esbaldam. Triste é imaginar que o espectador sempre acreditará que a culpa é de quem produziu o trabalho. Percebi que eu também assumiria o risco de ser tachada de "chapa branca" caso limitasse a escrita ao que Zé Ramalho e sua família e equipe quisessem. Com Zé, combinei que não sujeitaria meu livro ao julgamento dele ou de familiares, mas minha experiência como jornalista e pesquisadora já me mostrou que a liberdade de expressão não é tão livre assim em um país como o nosso. Com a Justiça jogando contra nós pesquisadores, se Onaldo me pediu para não ser incluído nessa história e se Ísis disse que não queria nossa conversa transcrita em alguma página, qual advogado pode me defender? O filme de Elinaldo me fez perceber que a mim restava pensar como incluir esses personagens, essenciais para a história que eu queria contar, na minha narrativa. A essa altura do meu envolvimento com o projeto de escrita, eu já sabia que minha escolha também me colocaria na linha de tiro da crítica. Sobre isso, acho perfeita a análise de Caio Fernando Abreu no texto "De um adolescente rebelde", escrito para a revista Around, em que ele fala do próprio livro:

\begin{abstract}
Acho que todo mundo precisa saber com quem lida. Também porque um escritor é uma criatura indefesa: você publica o livro e fica à mercê da imprensa. Ninguém quer saber se você levou três ou quatro anos trabalhando um texto, se você quase morreu, se você passou até por dificuldades materiais em função de conseguir tempo para escrever. Quando o livro sai escrevem barbaridades, e o escritor - um enjeitado do sistema - tem que ficar quieto. Eu não fico quieto e estou me permitindo usar este espaço para fazer essa denúncia. (DIP, 2009, p. 204)
\end{abstract}

Não tive a oportunidade de conhecer a Luciane Alves nem o Henri Koliver para perguntar a eles o que os fez subverter a ideia de biografia. Mas decidi escrever uma carta para cada um, na esperança de obter respostas. Só não consegui enviá-las, porque não localizei nenhum dos dois escritores e, também, porque achei que meu ato subversivo não acrescentaria tanto em minha pesquisa, afinal, eles não iam querer me responder ou, se respondessem, não teriam muito a contar além do que já está em suas publicações. 


\section{Carta 1: Luciane Alves}

Rio de Janeiro, 23 de maio de 2009.

Cara Luciane,

Não nos conhecemos, mas confesso que fiquei bem curiosa sobre você depois de ler o livro "Zé Ramalho: Um visionário no século XX". Minha curiosidade ultrapassa um pouco a barreira de sua narrativa e entra também na questão pessoal. Acalme-se, pois não quero saber 0 que você não quer contar. Estou iniciando uma pesquisa para uma nova biografia de Zé Ramalho e acessei o seu trabalho na esperança de achar nele algo que pudesse complementar o meu. Meu interesse é na relação de afeto que você tem com a obra desse artista. Eu adoraria saber porque você escolheu Zé Ramalho para escrever sobre e entender porque não mergulhou de fato nas histórias dele. Mesmo que demarcasse um limite de espaço e tempo e fizesse um recorte de sua vida ou mesmo que fosse apenas de sua obra, você teria conseguido publicar um livro interessante e gostoso de se ler. Mas, na medida em que ficou apenas divagando sobre ideias suas sobre Zé Ramalho, o conteúdo perdeu credibilidade e, para mim especialmente, ficou desagradável. Sou uma pesquisadora em formação e sinto muita falta de dados concretos nesse seu trabalho.

Sua análise sobre as obras de Ze Ramalho parece viciada, mas entendo que esse vício precisa ser localizado no tempo e espaço correto para ser compreendido. Houve uma época, entre as décadas de 1980 e 1990, em que os fãs chamavam Zé Ramalho de "Profeta", devido às incompreensões nas quais esbarravam durante a tentativa de interpretar as letras das canções do artista. Ao ler o seu estudo sobre a vida e a obra do músico, percebi que você era uma dessas receptoras e que iniciou sua narrativa já imbuída de crenças e referenciais "mitológicos", "mediúnicos" e "simbólicos", parafraseando alguns dos termos que usa em seu texto. Você atribuiu a todas as suas análises opiniões e divagações que não me parecem ajudá-la no cumprimento de 
seu objetivo, que seria encontrar na trajetória de Zé Ramalho e, em pesquisas sobre a mesma, traços que confirmariam que, além do artista, seu objeto de estudo seria também um visionário. Pelo menos o título do liuro e a introdução escrita por Waldemar Falcão, músico e amigo de Zé, fazem um desavisado acreditar que é isso que ele encontrará nas 135 páginas. Mas percebe-se que você, viciada em ouvir Zé Ramalho como se tudo o que ele cantasse fosse uma mensagem, esqueceu de aprofundar mais sua apuração para perceber que muito do que o compositor da Paraiba escreve (até hoje) é sobre seu presente, mesmo que fale neste tempo de suas memórias.

Os antigos procuravam manter um contato direto com os deuses, sem, para isso, precisarem ser julgados por leis criadas por outro homens. Infelizmente, porém, com o passar dos anos, tudo que foi ensinado por nossos antepassados acabou se perdendo ou sendo perdido de propósito. Muitos símbolos foram mal interpretados, e grande parte deles suprimida propositadamente dos antigos livros, que são os únicos registros que temos. Mas a mensagem dos nossos antepassados pode ser sentida. Ela se perpetua através dos tempos, pois nossas mentes têm uma ligação direta com este passado, com o Avôhai. (ALVES, 1997, p. 30)

Fiquei curiosa para entender o que (ou quem) você chama de Avôhai, afinal, este foi o apelido dado por Zé Ramalho ao avô no refrão e no título da canção que o homenageia. Pareceme que, com seu horizonte de expectativas permeado por símbolos, você encarou "Avôhai" como uma canção profética, assim como vê todo o resto da obra de Zé Ramalho. Se você tivesse aprofundado sua pesquisas, conheceria o verdadeiro significado de "Avôhai".

O único parágrafo que me toca e com o qual me identifico no seu livro está no segundo capítulo, intitulado "As visões de Zé Ramalho para o final do século XX", no qual você não enumera as "visões" que cita no título nem as relaciona com as canções de Zé, mas assume que sua intenção era interagir com seu objeto de estudo no campo dos afetos:

Neste trabalho, pretendo "botar pra fora" a emoção que sentimos quando ouvimos o cantador Zé Ramalho. Algo que atinge nossa alma. Em cada uma de suas canções, registramos uma força que nos 
toca não só pela voz rouca ou pelos lindos arranjos, mas também pelo sentimento de que não é apenas uma música e sim uma mensagem que deve ser interpretada e compreendida. Pretendo trazer suas canções para o cotidiano de nossas vidas e mostrar que toda mensagem entendida deve ser colocada em prática para que possamos construir um mundo melhor. A voz do cantador Zé Ramalho não nos traz somente músicas bonitas, mas também a oportunidade de aprender a reconhecer o que somos e o quanto podemos melhorar ainda no século XX para então, no final do milênio, juntos, canalizarmos toda a energia para um mundo novo que deve começar dentro de cada um de nós, independentemente de cronologia ou espaço (ALVES, 1997, p. 28).

Mas não concordo com o que fala sobre a voz de Zé Ramalho ser rouca, tampouco com a obrigação que sugere de termos de interpretar, compreender e colocar "em prática" "a mensagem" disseminada pelo autor através de suas canções. Você mesma reconhece que muitas são incompreensiveis no primeiro capítulo de seu livro. Não há uma entrevista em minha coleção de matérias publicadas em jornais e revistas desde a década de 1970, copiadas durante as pesquisas que venho fazendo em arquivos de centros de mídia, que mostre Zé Ramalho incitando mitos ou deixando de explicar as mensagens das canções.

Desculpe te falar isso dessa maneira, mas é que seu livro atrapalha minha busca por editoras - alguns editores já perguntaram sobre a importância do meu projeto se Zé Ramalho já tem dois livros escritos - e ainda me faz ter que percorrer um caminho mais longo na conquista pelos fãs, que acabam desacreditados por acharem que minha publicação é só mais um produto caça-níquel. Veja bem, não estou dizendo que você escreveu por dinheiro. Tenho certeza de que 0 fez por paixão ou admiração. Mas, enfim, acho que você deve estar me entendendo. Quem sabe depois de ler essa minha carta, você se anima em arrumar os trechos mal elaborados?

Atenciosamente,

Christina Fuscaldo 


\section{Carta 2: Henri Koliver}

Rio de Janeiro, 23 de maio de 2009.

Caro Henri,

Não nos conhecemos, mas confesso que fiquei bem curiosa sobre você depois de ler o livro "Zé Ramalho - O poeta dos abismos". Tenho uma autorização de Zé Ramalho para escrever uma biografia e foi ele quem me deu o seu livro, para que eu pudesse usá-lo como fonte de pesquisa. Para isso, o seu trabalho vai ser realmente muito útil. Mas, na medida em que fui avançando na leitura, uma questão foi ganhando forma e fiquei com muita vontade de formular uma pergunta. Gostaria de pedir permissão para fazê-la através desta carta: Com tanto material em mãos, ou seja, entrevistas sem censura de Zé Ramalho sobre todos os tempos e de pessoas que conviveram ou trabalharam com ele, por que você não executou seu plano inicial, de narrar a história do artista a partir dos acontecimentos que marcaram sua vida e obra? Você dedicou tanto tempo seu e fez Zé e alguns de seus parceiros dedicarem tanto do deles para, no fim, simplesmente transcrever as entrevistas. Fora isso, você confessou no capítulo "Nota do autor" que a revisão foi feita por Roberta sem informar ao leitor se houve algum tipo de corte ou censura do material exposto à esposa de Zé, o que me leva a crer que também foi exposto ao próprio Zé. Se a intenção fosse essa mesmo, tudo bem. Mas, pelo que me contou Zé Ramalho quando pedi a autorização, sua ideia era escrever uma biografia.

Na minha opinião, o contorno que você deu à narrativa faz com que seu liuro, apesar de ter muitas passagens interessantes, não possa ser chamado de biografia. Eu poderia simplesmente ler "Zé Ramalho - O poeta dos abismos" e tirar dali o que me interessasse, mas fiquei um pouco incomodada pelo fato de esse seu trabalho estar entre os termos de minha negociação com Zée e, de certa forma, atrapalhando a mesma. Sei que você não tem culpa, mas, se 
não for com você e com o Zée, a quem também pretendo recorrer em algum momento na tentativa de rever nosso combinado, com quem vou desabafar? Em sua nota, você conta que se surpreendeu com tamanha disponibilidade de Zé Ramalho. Eu diria a mesma coisa se ele não tivesse se decepcionado, de certa forma, com o resultado de seu trabalho. Agora, dependo da assinatura de um contrato com uma editora para conseguir o tempo que você teve com Zé. E tudo porque ele não quer mais confiar em algo que pode não dar certo, como ele achou que ia acontecer com seu livro. Em 2007, ele comentou que perdeu muito tempo dando entrevistas para projetos que não saíram ou viraram liuros muito diferentes do que propuseram a ele. Ele falava sobre as tardes que passou com você, se não me engano há aproximadamente dez anos, e que não renderam a biografia que você havia prometido. $O$ livro acabou saindo no ano passado. Falava também sobre o da Luciane Alves, um estudo sem apuração sobre algumas questões relacionadas a ele que virou uma compilação de dados que não servem nem como material de pesquisa.

Durante minha leitura, percebi que os tempos são outros. Naquela época, você encarou Zé Ramalho como o artista mítico, o "poeta do apocalipse", e não ligou uma entrevista que fez à outra nem relacionou as histórias narradas pelos personagens que entrevistou. A leitura é cansativa. Zé é um músico maravilhoso e é ótimo no palco, mas não é um típico contador de histórias. Meu interesse é escrever sua trajetória em forma de romance. Lamento não ter conseguido esse espaço que você teve com Zé. Sei que ele tem driblado a própria regra, convidando-me a trabalhar em projetos seus e, dessa forma, dando-me as entrevistas que eu não conseguiria fazer na sala de sua casa. Mas ainda acho pouco. 0 problema foi ele ter acreditado que "O poeta dos abismos" seria isso que estou tentando fazer.

Espero que não fique chateado com minhas palauras e que compreenda meu desabafo.

Atenciosamente,

Christina Fuscaldo 


\section{Um estágio com a Legião Urbana}

Entre 2008 e 2009, fiz dezenas de entrevistas e pesquisas em jornais e revistas dos anos 1980 e 1990 e em livros, para conhecer a história de cada disco da banda formada por Renato Russo, Dado Villa-Lobos e Marcelo Bonfá. A gravadora EMI, detentora do catálogo da Legião Urbana, relançaria seus oito álbuns em LP e CD, sendo que cada um ganharia um encarte com a história de sua gravação. Deixei de lado o projeto Zé Ramalho e encarei a dificuldade que estava enfrentando na busca por uma editora como um sinal: isso está acontecendo para me ensinar alguma coisa. Submersa há tanto tempo na obra desse artista místico e cheio de superstições, àquela altura eu já estava criando signos e símbolos para tudo também. Para mim, não era para ser. Pelo menos não naquele momento. Aceitei o convite da EMI e constatei: a pesquisa sobre Legião Urbana me mostrou que escrever uma história não é tarefa fácil nem para uma jornalista acostumada à correria e à pesquisa. O baterista, Bonfá, foi um entrevistado solícito, mas sua memória o trai e tentou trair a mim o tempo todo. "El poder de la memoria reside también en su extraordinaria capacidad de olvido." (GIORDANO, 2006, p. 172) O guitarrista, Dado, parecia mais confiável, pois ainda se lembrava bem de datas, locais e acontecimentos. Cada um dos personagens tinha sua característica e era eu a responsável por organizar tudo em textos que se aproximassem ao máximo do que me contavam. Eu já sabia que um entrevistado pode ter interesse em divulgar o seu personagem como the convém e isso poderia ser a pior armadilha para mim. Por isso, mesmo quando a história me parecia confiável, eu a levava a outras fontes para conferir a veracidade dos fatos. Deu trabalho e mostrou-me que, com meus recortes, discos e livros, eu tinha percorrido menos de $20 \%$ do caminho para escrever uma boa biografia de Zé Ramalho. Foi um aprendizado, pois eu não tinha lido ainda as considerações de Jacques Derrida sobre arquivo. Para o filósofo... 
[...] se esta palavra ou esta figura se estabiliza em alguma significação, não será jamais a memória nem a anamnese em sua experiência espontânea, viva e interior. Bem ao contrário: o arquivo tem lugar em lugar da falta originária e estrutural da chamada memória (DERRIDA, 2001, p. 22).

Nesse mesmo 2009, resolvi que faria do problema com as editoras a solução e decidi começar as pesquisas para o livro sozinha. Planejei para fevereiro de 2010, quando finalizaria a escrita sobre a Legião Urbana, minha primeira visita à Paraíba e a segunda a Pernambuco, para onde viajei em setembro de 2009, acompanhando minha amiga pernambucana Érika Azevedo na cobertura de um festival. Ela foi enviada pelo site de O Globo e eu fui colher material para meu recém-lançado blog, o GarotaFM.

\author{
De: Christina Fuscaldo \\ Para: Ze Ramalho; Roberta Ramalho \\ Enviadas: Terça-feira, 24 de Novembro de 2009 13:33 \\ Assunto: Programa para 2010
}

Zé,

Ando conversando com algumas pessoas, mas ainda não é certo termos editora em 2010. Muitos dos editores têm pedido o material para analisar. Só que, conforme combinamos, não iniciei os textos e não tenho nada a mostrar. Para escrever sua história, não bastam apenas as entrevistas com você, mas o acesso à familia e às cidades por onde passou. Pensando nisso, tive a ideia de ir a João Pessoa em fevereiro de 2010. De lá, pensei em ir a Natal e Recife, se você e as apurações me disserem que há fontes também nestes lugares. Gostaria de pedir para que me permita quebrar nosso pacto e que me coloque em contato com sua familia na Paraiba. Assim, começo a colher material para escrever entre março e abril e, em junho, já vou poder oferecer o liuro às editoras. 0 que me diz?

Beijos,

Chris 


\section{A primeira visita à Paraíba}

O e-mail não foi respondido, o que me causou um sentimento estranho, mas comprei as passagens mesmo assim. Meu desejo investigatório estava latente. Fora isso, eu me sentia mal por não conhecer ainda a terra de Zé Ramalho: "A ignorância que têm da sociedade nordestina é maior do que a dos seus problemas socioeconômicos." (SANTIAGO, 2013, p. 89). Na redação de O Globo, pedi à editora que me demitisse em julho de 2009 porque queria me dedicar ao livro, às bandas e aos trabalhos como freelancer que estavam me dando mais retorno financeiro e emocional. O site estava sofrendo modificações e ficamos sabendo que ele passaria a ser mais um reprodutor das matérias publicadas no jornal, com algo de interação para marcar a diferença, do que um espaço com vida própria. Isso acabou não acontecendo, mas havia outra questão: eu andava decepcionada com as pautas que minha editora estava priorizando na redação e com o comportamento dos leitores, ainda em processo de adaptação aos novos meios de comunicação. Se bem que, levando em conta a definição dos leitores da primeira metade do século passado, analisados pelo Graciliano Ramos de Silviano Santiago, nada mudou:

O leitor de jornal (ou de romance espontâneo) não quer fazer esforço algum quando lê. Contenta-se em absorver a escrita de um outro como se fosse um papel mata-borrão. Deixa-se guiar apenas pelas faculdades da memória e não pelas da reflexão. Este leitor tem uma visão fascista da literatura. (...) Fascismo existe todas as vezes em que o ser humano se sente cúmplice e súdito das normas. O homem deixa-se invadir por modelos de comportamento que não representam a sua energia, mas que o transformam em um uniforme a mais. (SANTIAGO, 2013, p. 125)

Eu queria mais do que matérias que falassem superficialmente do que estava na moda ou não, mas percebi que estava vivendo como os profissionais descritos por Graciliano: "Em nome do salário no fim do mês, do profissionalismo e do prestígio entre seus pares, vão engolindo a seco imposições que acabam 
por torná-los autores de textos impessoais, por destruir-Ihes qualquer idealismo" (SANTIAGO, 2013, p. 194). Tentando ainda fugir do bullying de Bianca, que assumiu a coordenação da editoria de cultura do site no segundo semestre de 2008, após a saída do nosso editor Rodrigo Pinto - e até hoje não sei porque vinha tentando de tudo para que eu pedisse demissão -, coloquei no ar um blog que há anos eu vinha planejando, o GarotaFM, e comecei a produzir matérias e a editar meu próprio veículo de comunicação. Além de tudo isso, eu estava me separando e, fora do jornal, o carnaval de 2010 seria o primeiro depois de cinco anos em que eu não precisaria trabalhar. Sem retorno de Zé, pensei, então, que, na pior das hipóteses, em vez de pesquisar, eu iria curtir as praias paraibanas para depois mergulhar na folia pernambucana.

No dia 03 de fevereiro de 2010, mandei mais uma mensagem, por desencargo de consciência, e embarquei para João Pessoa junto com um dos meus melhores amigos da adolescência, Rodrigo Peixoto, que topou juntar o útil ao agradável e alternar dias de folga com outros de trabalho: além de fotografar os personagens de uma matéria que combinei de fazer para a Rolling Stone, que nada tinha a ver com Zé Ramalho, Rod registraria imagens da Pedra do Ingá, que fui visitar para tentar entender como o lugar inspirou Zé e Lula Côrtes na gravação do LP "Paêbirú - Caminho da montanha do sol", lançado em 1975 pela gravadora pernambucana Rozenblit. Cristiano Bastos, jornalista gaúcho que também era colaborador da revista, não só havia estado no município de Ingá do Bacamarte, onde está localizada a pedra com as inscrições, como tinha levado Lula e feito um registro em vídeo que, mais tarde, viraria o documentário "Nas paredes da pedra encantada". Quando o conheci pessoalmente, em um evento do Ministério do Desenvolvimento Agrário ocorrido no Rio em outubro de 2009, no qual coincidentemente nós dois trabalhamos, falei na hora: "Tenho muita inveja de você por ter ido com Lula na pedra e por ter feito para a Rolling Stone a entrevista com Zé Ramalho que eu não pude fazer". Ficamos amigos.

Roberta respondeu meu e-mail, no maior alto astral, desmistificando minha sensação de abandono e me passando os contatos de Zélia Pordeus Ramalho, a irmã mais nova do pai de Zé, e de Hugo Leão (ou Hugo Filho), que além de melhor amigo dele foi seu parceiro de banda na década de 60. Li a mensagem 
assim que cheguei na capital paraibana e me instalei no maravilhoso hotel Hardmann, oferecido pela secretaria de Turismo da cidade e localizado na beira da praia de Manaíra. Apesar do silêncio dos Ramalho, eu tinha me articulado e buscado apoio para meu projeto. Minha ideia era correr atrás de material, independente da chegada da resposta. Se eu conseguisse cópias de matérias publicadas em jornais locais ou contatos de pessoas que se relacionaram com Zé Ramalho - mesmo que fosse para eu entrevistar depois, em outro momento já estaria muito bom. E acabou que eu consegui muito mais que isso. Naquela mesma noite, enviei e-mails para tia Zélia, para Hugo e para um amigo jornalista que conhecia das coberturas de festivais feitas durante o período em que trabalhei nas redações da Infoglobo. André Cananéa foi quem estreitou meu contato com a secretaria e me apresentou a Silvio Osias, jornalista nascido na Paraíba em 1959, dez anos depois do meu futuro biografado, e que era adolescente quando Zé já tinha fama como guitarrista de conjunto de baile. Silvio me passou diversos nomes de pessoas que ele viu fazer parte da trajetória de Zé Ramalho e ainda me contou muitas histórias que só os paraibanos se lembram. Gravei e anotei tudo. Nos dias que se seguiram, fiz ainda contato com Lula Côrtes e falei com Raul Córdula, designer responsável pela maioria dos trabalhos gráficos da época. Ambos moravam em Pernambuco - o primeiro em Jaboatão dos Guararapes e o outro em Olinda - para onde eu iria uma semana depois, quando começaria o carnaval. Não sem antes mandar notícias para Zé.

João Pessoa, 05 de fevereiro de 2010.

2é,

Como pôde ler acima, estou aqui. Mal posso acreditar que esse lugar existe e que é mesmo uma capital. Não conheço todas as capitais dos estados brasileiros, mas de tudo o que já vi, nunca tinha experimentado um lugar tão aconchegante. João Pessoa é uma cidade linda! Que praias magníficas! Que gente hospitaleira e agradável! Acho que essa carta chega a você antes de 
eu chegar ao Rio, afinal, ainda tenho uma jornada em Pernambuco. Fiquei com vontade de te escrever logo porque não precisei mais do que dois dias para descobrir um montão de coisas e eu gostaria de compartilhar algumas delas para que possa ir pensando numa possivel revisão. Lembrese de que só vale sugerir alteração de datas, locais ou contextualizações equivocadas. Não aceito censura às histórias, viu? Há uma jornalista americana chamada Janet Malcolm que diz que o leitor só tolera a biografia se ele se sentir cúmplice do biógrafo, ou seja, se ele se sentir espiando pelo buraco da fechadura. Adoro essa metáfora e concordo com ela: não posso deixar de dar ao seu fã o que ele mais espera desse livro, não acha? Bom, vamos ao que coletei por aqui. Já uso, no texto a seguir, o estilo de narrativa que quero adotar na escrita da sua biografia.

\section{O iê-iê-iê tropicalista paraibano}

Três dias após Zé Ramalho completar 18 anos, a terceira edição do Festival da Música Popular Brasileira da TV Record, realizado em 6 de outubro de 1967, mudou os rumos da história da música no Brasil. Após muitos debates, Gil e Caetano, cada um com uma música inscrita, resolveram se apresentar acompanhados de bandas que usassem instrumentos eletrônicos como a guitarra elétrica, inspirados pelos artistas da Jovem Guarda. Antes de ser um movimento musical, Jovem Guarda foi o nome do programa que estreou em 1965, na TV Record de São Paulo, e era apresentado pelos artistas da chamada "geração iê-iê-iê", que reunia, entre outros, Roberto Carlos, Erasmo Carlos e Wanderléa. Ela surgiu no momento em que a música brasileira se debatia entre a bossa nova e as canções de protesto. Totalmente alheia aos problemas sociais, políticos e qualquer outra coisa que não fosse relacionada a palavras como "amor", "tesão", "beijo", "arromba" e "brasa", a Jovem Guarda atuou como tradutora nacional do rock'n'roll e se consagrou como o primeiro fenômeno de massa da cultura pop no Brasil.

$A$ atitude de Caetano e Gil foi considerada uma aberração numa época em que a música brasileira - e tratava-se de um festival de MPB - 
se baseava no violão, nas letras e nas vozes. Guitarra era coisa da "turminha alienada do iê-iê-iê". Enquanto Caetano apareceu no palco do Teatro Paramount de São Paulo com "Alegria, alegria", acompanhado pelos argentinos da banda Beat Boys, Gil defendeu "Domingo no parque" com a banda paulista Os Mutantes. Aplausos e vaias se misturaram no auditório: era a primeira vez que guitarras elétricas entravam no palco de um festival de MPB e isso era um insulto à cultura nacional para os mais "xiitas". Mas não foram só a guitarra e o baixo elétricos os merecedores das vaias, não. Os rapazes do Beat Boys usavam cabelos compridos e Caetano, um paletó de tweed marrom com uma camisa de gola rolê laranja. Os roqueiros do Mutantes, Rita Lee e os irmãos Arnaldo e Sérgio Dias Baptista, entraram no palco com roupas extravagantes e não com os costumeiros smokings ou vestidinhos tradicionais da época. Gil ainda foi menos vaiado já que chegou a aplicar um pouco mais de "brasilidade" em sua apresentação: além do berimbau, a roupa era bem brasileira, para não dizer bem nordestina (uma calça curta e chapéu em forma de cuia). Gil conquistou o segundo lugar, atrás de Edu lobo, com a música "Ponteio". Com toda essa atitude exalando "subversão tanto no palco quanto nos bastidores", o III Festival da Música Popular Brasileira da TV Record foi decisivo para a afirmação do movimento chamado mais tarde de Tropicalismo.

Tanto Gil quanto Caetano (e a maioria dos outros tropicalistas) eram admiradores declarados da bossa nova e, principalmente, da voz e do violão de João Gilberto, o que mostra que eles não renegavam nenhum estilo. Com o aparecimento, em plena época de ditadura militar, de artistas capazes de misturar influências e referências sem preconceito tanto em sua arte quando em seus trajes, linguagens, discursos etc, iniciou-se uma nova era na música brasileira. Depois do Tropicalismo, passou a ser proibido proibir e muitos outros artistas criaram coragem para arriscar. $O$ movimento incorporou elementos da arte e da música pop à música brasileira, tornando-a universal e, consequentemente, ditando novas regras comportamentais para uma geração incomodada e que ansiava mudanças. O Tropicalismo promoveu a eletrificação instrumental, fazendo 
a polêmica introdução da guitarra nos arranjos. Os Beatles se tornaram a principal referência musical estrangeira, sobretudo por seu álbum mais experimental, o "Sgt. Pepper's Lonely Hearts Club Band". Abarcando, além da música, outras artes - como o filme "Terra em transe", de Glauber Rocha; a peça "O rei da vela", uma adaptação montada por José Celso Martinez Corrêa; a poesia e a filosofia antropofágica do modernista Oswald de Andrade (autor de "O rei da vela"); e a instalação "Tropicália", do artista plástico neoconcretista Hélio Oiticica - o Tropicalismo se tornou um movimento de vanguarda que se mantém jovem e atual até hoje.

Em 1967, os Beatles também já tinham invadido João Pessoa, a capital da Paraíba, onde José Ramalho Neto morava com seus avós e tias. E, já a essa altura, completamente extasiado com a música do quarteto britânico, o adolescente tinha em seu currículo alguma experiência com o rock'n'roll: depois de tocar guitarra com os conjuntos Os Jets, Os Eles e Os Demônios, no ano em que completou a maioridade ele estava integrando Os Quatro Loucos. Com o grupo do qual fez parte Vital Farias - paraibano que impressionou Zé desde que este o viu tocar pela primeira vez - fez o show de abertura na noite em que o Clube Astréa receberia Roberto Carlos. Depois de abandonar tudo para servir o Exército durante um ano - onde acabou montando um conjunto também - Zé foi convidado pelo amigo Luiz Hugo Guimarães Filho a integrar a banda de baile The Gentlemen. O quarteto com Huguinho - ou Hugo Leão, como Zé o rebatizou quando o amigo gravou seu primeiro disco, no final da década de 1970, no Rio de Janeiro -, além de canções dos Beatles, levava aos palcos dos principais clubes da cidade e arredores as versões para o português de hits estrangeiros feitas por Renato Barros, Leno e Lílian, Roberto Carlos, Erasmo Carlos e Golden Boys. A bagagem musical que o guitarrista vinha adquirindo ao passar horas tocando seu violão, quando estava em sua casa, e a guitarra que o pai de Hugo comprara para a banda, quando estava na casa do amigo, e ao prestar atenção em outros nomes da cena internacional, como Rolling Stones, Carlos Santana e The Who, fez a banda The Gentlemen crescer muito musicalmente. The Gentlemen ou, como costumam falar hoje em dia, "Os Gentlemen" eram 
um sucesso e, devido ao respeito que conquistaram, chegaram a tocar em estados vizinhos. Bem no início da década de 1970, viajaram para Manaus (AM) em um navio chamado Ana Neri, que serviu de palco para o rock'n'noll de sotaque paraibano nos 27 dias em que estiveram a bordo.

Assim se passou a Jovem Guarda no estado de onde tinha saído Sivuca, o acordeonista que ganhou o mundo depois que sua própria terra rejeitou os ritmos que ele tocava em seu acordeon. Nessa mesma época, Zé compôs sua primeira música: intitulada "Fim de Romance", uma balada romântica (ou, como se dizia na época, "mela cueca") que, depois de mais de 40 anos e sem nunca ter sido gravada, ele a resgatou em seus arquivos, rebatizou-a de "Chegou ao Fim" e enviou a Hugo para que o amigo avaliasse a possibilidade de registrá-la em um de seus discos. Com essa canção, a única irmã de Zé, Goretti, venceu o concurso de quem cantava melhor no Esporte Clube Cabo Branco. Na verdade, a primeiríssima composição de Zé foi uma valsinha que fez a família toda aprender para cantar na missa em celebração pelas Bodas de Ouro dos seus avós. Era assim: "Cinquenta anos vividos, sofridos, porém tão cheios de amor / Cinquenta anos guardados, amados, tirem o chapéu por favor". Também nessa fase, ao contrário de Hugo, que era obrigado pelos pais a meter a cara nos livros, Zé não se dedicou, mas, também ao contrário do amigo, passou no vestibular para o curso de Medicina na Universidade Federal da Paraíba, onde estudou por dois anos até dar o seu grito de liberdade e avisar ao avô que não queria mais ser médico e, sim, músico. A chegada das músicas tropicalistas nas rádios paraibanas só contribuiu para que o aspirante a artista decidisse mergulhar de vez na música e investir na profissão.

Beijos, 


\section{Histórias para rir}

Hugo Leão é o amigo boa praça de Zé. Sempre de alto astral, diverte-se muito com as memórias que tem dos tempos do The Gentlemen. Uma delas leva Huguinho de volta ao navio Ana Neri, no papel de cinegrafista do "The Drunks", um filme que Zé dirigiu e protagonizou, mas nunca divulgou. Gravado nos intervalos em que o quarteto não estava no palco, no cartucho Super-8 está a prova de que os músicos não eram maus atores, afinal, os registros não eram apagados ou editados. "A gente já filmava editando. Não podíamos errar. Era dar o sinal que o Lira vinha vestido de garçom para servir o Zé e o Célio, que ficavam bêbados. A gente morria de rir", lembra Hugo, que gargalhou também quando eu perguntei a ele, durante a entrevista que me deu na recepção do meu hotel, sobre o humor do seu melhor amigo: "Ele detestava quando alguém pegava um papel, dobrava e fazia assim com a mão. Aí, um dia, o nosso baterista começou a amassar o papel. Estávamos todos jantando em uma mesa, inclusive meus pais, e Zé pediu para ele parar. Lira continou. De repente, Zé deu um tapa na mesa que fez voar prato para tudo que é lado, falou uns palavrões e foi embora." Os pais de Hugo se chamavam Laís e Luiz Hugo Guimarães. Ele foi bancário e um grande incentivador das investidas do filho único na música. Ela também gostava de ver Huguinho no palco, principalmente se ele fosse tocar com as roupas que a mãe costurava para todos da banda.

O baixista conheceu Zé no início da década de 60 , mais ou menos na época em que saiu da banda Os Quatros Loucos, na qual, logo depois, Zé entrou. Mas a amizade só se intensificou mesmo depois que Zé deixou o Exército e aceitou o convite de Hugo para integrar o conjunto The Gentlemen, na ativa desde 1966. Mais uma história que ele conta rindo é a do fim dessa jornada militar do amigo: "Zé ficou no Exército um ano. No dia em que ele foi dispensado, ficou tão empolgado que arrancou com o Fusca de uma das tias e deu um rabo de arraia. Só que ele ainda estava dentro do quartel. O coronel viu a cena e 
ordenou que ele entrasse novamente. Zé ficou preso uma semana." Se Zé gostava de aprontar, Hugo era o cara que incentivava para poder ter do que rir. Certa vez, seu Luiz tinha acabado de mandar vir de São Paulo uma guitarra Begher quando os meninos tiveram a ideia de copiar do "Woodstock", documentário sobre o antológico festival realizado em 1969 nos Estados Unidos, a cena em que Pete Townshend, da banda The Who, bate com sua guitarra no chão e a joga para a plateia: "Em 1974, estávamos tocando uma música do Carlos Santana, em uma festa de formatura no Sport Club do Recife. Zé olhou para mim e logo pensei: 'Pronto, agora não tem mais jeito.' Ele bateu com a guitarra no chão com toda a força e o baterista começou a furar os bumbos e jogar as baquetas. A plateia enlouqueceu. Depois, meu pai só perguntou quem é que ia pagar o prejuízo e prometeu descontar do nosso cachê. Ele acabou nunca cobrando, mas pediu que avisássemos na próxima vez em que quiséssemos fazer aquilo. Eu sempre sabia se Zé ia aprontar pelo olhar."

Hugo me contou também sobre a participação que fez como tecladista e baixista no último show que Zé Ramalho apresentou em João Pessoa antes de embarcar para o Rio, "Um dia antes da vida", em 1976. De cara, o agora líder exigiu que o melhor amigo e os outros músicos - Walmir e Edmilson (percussões e vocais) e Irapuan (bateria e percussão) - deixassem que seus rostos fossem pintados. "Zé tocou músicas próprias que, depois, foram entrando em seus discos. Ele fez discurso e esculhambou a TV Globo e o programa do Silvio Santos, dizendo que a televisão não abria espaço para os artistas. Mas em política ele nunca se meteu. Outro show que fizemos juntos, em 1974, foi o 'Três aboios diferentes', que era eu no teclado, ele na guitarra e Jarbas Mariz na viola. Com Paulo Batera na bateria e Baby no baixo, mostramos músicas próprias."

A conversa com Hugo foi longa e divertida, mas a sensação que eu tinha era de que o melhor amigo do meu biografado havia construído a imagem que Zé Ramalho gostaria de divulgar nas entrevistas que costuma dar caso conseguisse ser uma pessoa mais leve. Quando fala de si mesmo, Zé constrói um personagem de personalidade forte, um homem seguro, mas também difícil. "Para escribir sobre sí mismo (el que es) el autobiógrafo necesita construirse como otro (el que fue)." (GIORDANO, 2006, p. 173) Ele não é, oficialmente, um 
autobiógrafo, mas precisa assumir essa posição toda vez que se coloca no papel de narrador de sua própria história. Imagino eu que isso ocorra porque "la escenificación de los recuerdos necesita inmovilizar el pasado para someterlo cómodamente a una forma dramática y distanciar al lector de lo que ocurre para ponerlo en posición de espectador." (GIORDANO, 2006, p. 187) Mesclar essa faceta de Zé Ramalho com a que Hugo me apresentou era o que eu precisava para alcançar o equilíbrio que desejava para meu livro. Até ali, a trajetória de Zé Ramalho me parecia um pouco pesada, mas seu amigo paraibano me mostrou um outro ponto de vista. Zé me indicou a pessoa que ele sabia que tinha passado a vida vendo o lado engraçado das coisas. Por causa dele, consegui começar a planejar capítulos bem mais divertidos.

Depois de mais de duas horas de conversa, ali mesmo no hotel, Huguinho me contou que chegou a gravar com Zé Ramalho, só que ficou de me passar mais informações depois, visto que a hora avançou e eu precisava pegar o ônibus para Recife. Naquele dia, eu estava posando de popstar, pois tinha figurado a matéria de capa do Jornal da Paraíba ${ }^{23}$ sobre a escrita da biografia de Zé Ramalho. No dia seguinte, já em Pernambuco, recebi em minha caixa de emails 0 arquivo no formato PDF com a entrevista e mais detalhes dessa história contada por Hugo. 


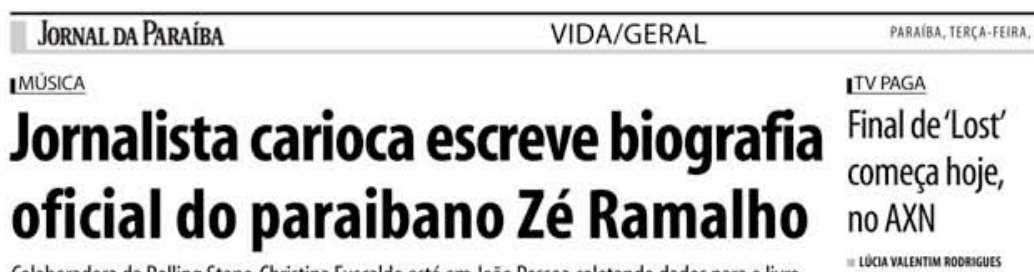

Colaboradora da Rolling Stone, Christina Fuscaldo está em João Pessoa coletando dados para o livro

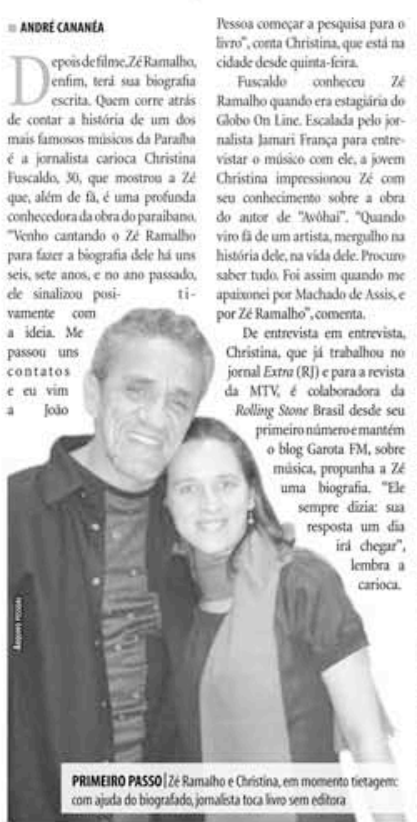

IMEMÓRIA

Lenda do jazz britânico,John

Dankworth morre aos 82 anos

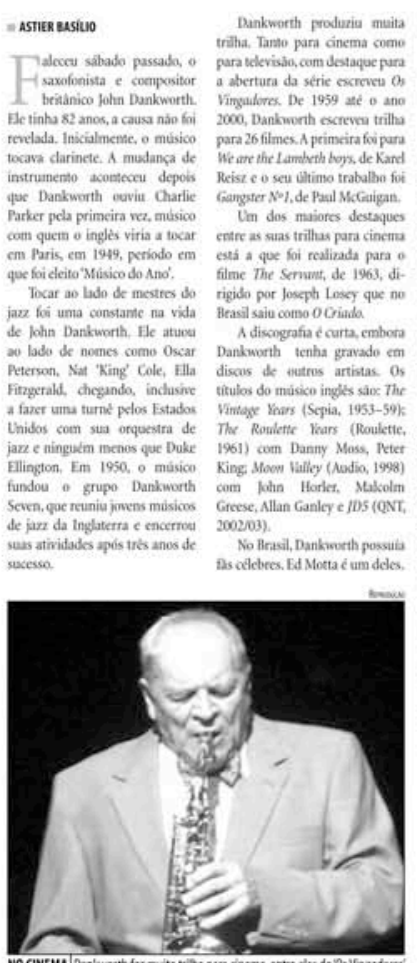

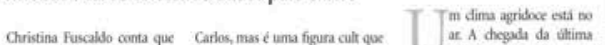

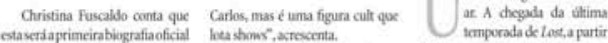

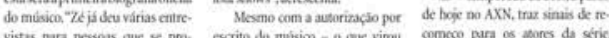

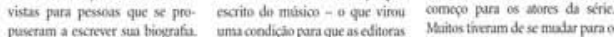

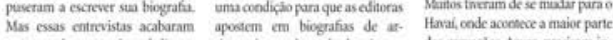

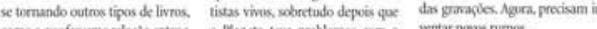

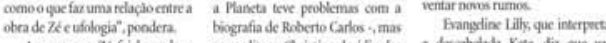

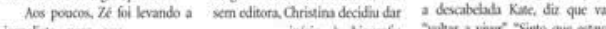
jormalista para soti

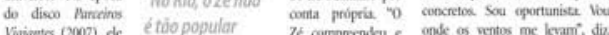

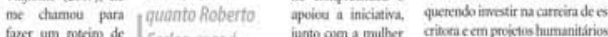

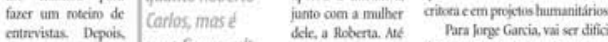
cettrnitas Depoik
me danmos para

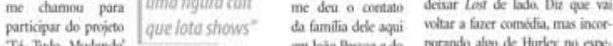
(2008). Sou en quem

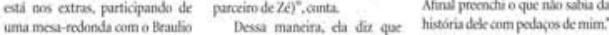

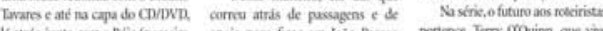

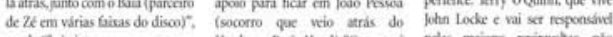

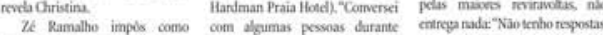

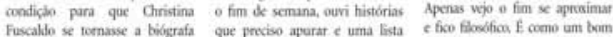

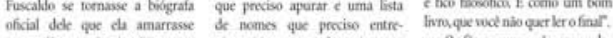

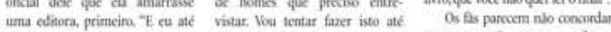

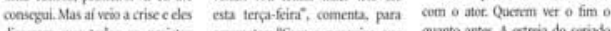

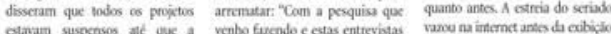

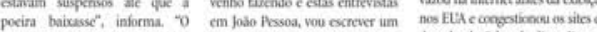

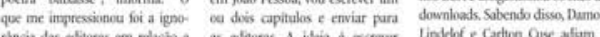

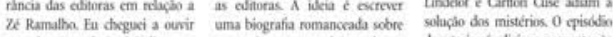

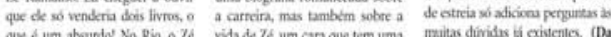

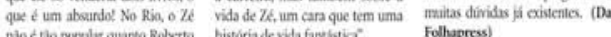
IDURANTE O CARNAVAL

'Festival Rec-Beat', no Recife, aproxima o Nordeste da música pop da América Latina Em sua 15a ediçăo, evento tem bandas da Colömbia,Argentina,México e Espanha

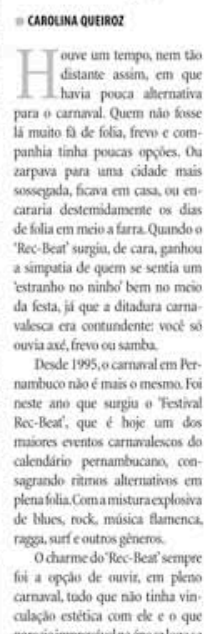

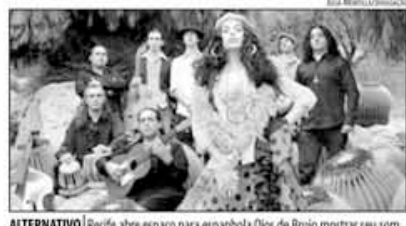

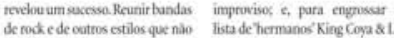

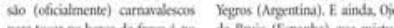

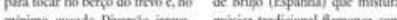

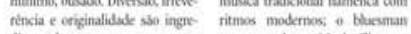

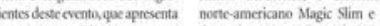

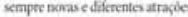
(a)

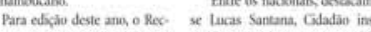
Antrats

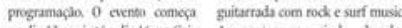

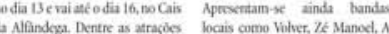

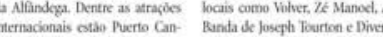

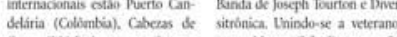

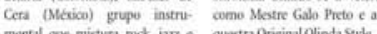

Confira a programaçao do palco principal

sameosis

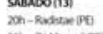
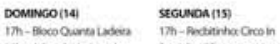

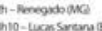

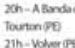

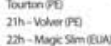

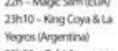

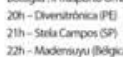

zh-Mosensun ind

conso- cours

and

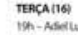

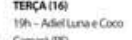

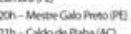

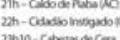

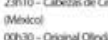

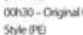

\section{RÁPIDAS}

'Up - Altas Aventuras' ganha prèmio

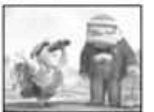

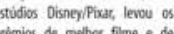
petmilos de methor filine e de

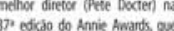
remia os methers dis indistrie tha animardio os prenios foram

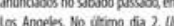
receber cinco indiaroes as 0 Oxat

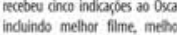

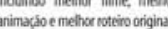
Prèmio que dá RS 400 mil abre inscriçōes

Estio doteras ate o data 5 de

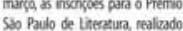

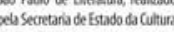

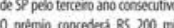
Mrat o omether romance de frecio

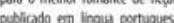
em 2009, atem de valas equiva lente para a methor obra de acai:

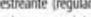

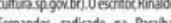
'Mágico de $\mathrm{O}^{2}$ ' inspira turnẻ de Lady Gaga

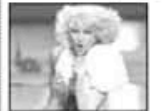

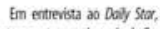

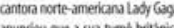

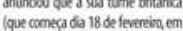

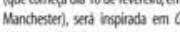

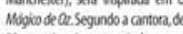

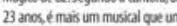
show nomal No enredo dise seus

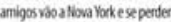
Guga foi und dors artistas que mis vendev discos na Gra beretanha en

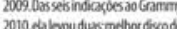

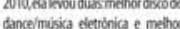
misita de dance.

Londres receberá festival brasileiro 0 centro aitural Sosthtank

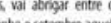
gre promete ser to mior trativa

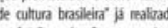

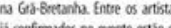

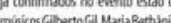
Amaldo Antunes e Tom Ze, as mudrate en o a arista plisticio Emesto litete

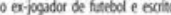
socrases

'Dear John' desbanca 'Avatar' nas bilheterias

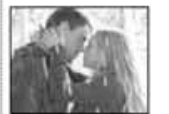

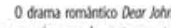
enceremu insperadamente as state semunas de Aivtar na biberanç

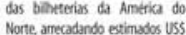

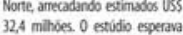
I2.2 ma abertion de cera de US 20

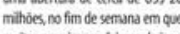

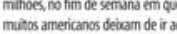

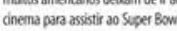
O flime 6 basedodo mo vomance de

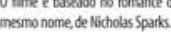


De: Hugo Filho

Para: Christina Fuscaldo

Enviadas: Quarta-feira, 10 de Fevereiro de 2010 16:40

Assunto: Gravações com Zé

Christina,

Espero que tenha gostado das histórias que contei. Relembrar tudo o que vivemos juntos é uma grande diversão. 0 Zé faz pose de durão, mas, no fundo, é uma pessoa doce. Fora isso, é o homem mais correto que conheci. Tanto que, quando ele se divorciou, testemunhei a favor dele, porque eu sabia que, apesar de morar no Rio, ele tinha mais condição de criar Christian e Antônio do que Ísis. Mas escrevi para falar da honestidade de Zé. Acho que não te contei como foi que ele se casou com a primeira mulher.

Eu não acreditei quando ele disse que ia se casar porque foi pego com Ísis na casa do tio onde ela estava morando. Ele pulou o muro e chegou lá em casa falando: "Acabei de me lascar, vou ter que me casar!" Eu tentei argumentar, mas ele disse que não tinha jeito. Zé é um homem de palaura. Mas ele gostava dela. Tanto que, quando estavam noivos, fomos para Manaus no navio e ele ficou agoniado. Zé nunca foi de ficar se declarando, mas às vezes o cabra ficava triste. Só depois de se mudarem para a a Vila do Sossego que a relação começou a desandar.

Antes do casamento, Zé passou uma temporada na minha casa. Mais ou menos nessa época, fomos os primeiros a chegar em João Pessoa com uma motocicleta Honda. A gente assistiu ao filme "Easy rider" e resolveu comprar a moto em Recife. Eu me empolguei tanto que fui para São Paulo fazer um curso de montagem. Depois, desisti e voltei a viver de música. Hoje, ajudo a produzir a Primaface, banda do Antônio, o filho mais novo de Zé com Ísis e da qual o meu filho faz parte. Na época em que Zé estava saindo do Gentlemen, envolvendo-se com o pessoal de Recife e viajando para o Rio, estávamos gravando um compacto com quatro canções. Ele participou de todo o processo, menos da foto de capa. O cara plantou, regou e, na hora de colher 0 fruto, não pôde estar. Depois, gravamos um LP pela Rozenblit já sem ele. Em 1978, mesmo ano 
em que Zé lançou seu primeiro LP, gravei o meu "Paraibô" com duas músicas dele e de Pádua Carvalho.

Desde que foi para o Rio, Zé tentou me levar junto. Fui algumas vezes, participei como tecladista em uma música e fazendo parte do coro de outra no disco "A peleja do diabo com o dono do céu". Toquei com Cátia de França, que era paraibana e ele também ajudou muito, inclusive a mantendo em sua banda e, depois, convencendo a CBS a abrir espaço para a gravação de um disco dela. Em 1983, ele me rebatizou de Hugo Leão quando assinei com a CBS e gravei o álbum "Coração de Brasil". Foi Zé quem produziu esse meu trabalho. No último que gravei, em 2008, ele participou cantando uma música minha. Por isso digo que Zé é generoso. Eu acho que ele não tem obrigação de fazer favor. E ele só faz o que gosta. Zé abraça o que ama e não se trai.

Quando ele se separou de Amelinha e estava na pior, Roberta chegou no Rio e cuidou dele. Essa paixão foi ótima para os dois. Ela é muito responsável, formou-se advogada e Zé virou outra pessoa, um homem sério demais. Engraçado que, apesar das farras, ele nunca deixou de cuidar das pessoas que ama. Quando a pessoa chega ao fundo do poço, é difícil ela ter consciência do que acontece ao redor, né? Mas Zé nunca se perdeu da familia. Todos sabiam que ele estava numa fase ruim, mas ele não deixou que ninguém ficasse abalado por isso. Que pena que você não terá a chance de conversar com a mãe dele. Dona Estelita sofre do Mal de Alzheimer e já não tem mais condições de contar as histórias que você quer saber da infância do filho. Como não pode morar em Recife e a irmã dele já faleceu, Zé contratou uma enfermeira para cuidar da mãe e ele sempre vai lá para visitá-la. Das mulheres que criaram e cuidaram de Zé, a única viva que ainda está lúcida é tia Zélia. E, olha, quer um conselho? Se forem conversar, não fale que viu Zé com uma camisa suja porque ela toma as dores. Zélia defende Zé com unhas e dentes.

Um abraço,

Huguinho 


\section{Histórias para para não contar}

Hugo estava certo, eu nunca entrevistaria Dona Estelita, que faleceu em 23 de outubro de 2012. Sobre a tia, a mensagem do amigo de Zé chegou tarde demais: no dia 08 de fevereiro, véspera do meu encontro com ele, eu tinha estado na casa de Zélia Pordeus Ramalho, em Manaíra. Preferi não the contar nada para evitar que as versões de certos episódios da vida de Zé Ramalho, narrados a mim pela tia caçula, influenciassem as versões que ele me daria. Tia Zélia é um doce, mas muito desconfiada. É compreensível, afinal, é a ela que os jornalistas recorrem quando querem descobrir algo sobre seu sobrinho famoso. Ao responder o primeiro e-mail que enviei, de cara pediu para que eu não levasse Rodrigo, meu amigo fotógrafo, para a entrevista. $\mathrm{Na}$ outra mensagem, sugeriu que, antes do nosso encontro, eu lesse a carta que ela havia deixado para mim na portaria do meu hotel, pois podia ser que a escrita respondesse as perguntas que eu tinha a fazer. Já cheguei na casa onde morou a avó de Zé, Soledade, até a sua morte, em 12 de janeiro de 1985, sabendo que Zélia é a maior defensora do sobrinho que conheci. Emocionei-me com os dois quadros expostos na
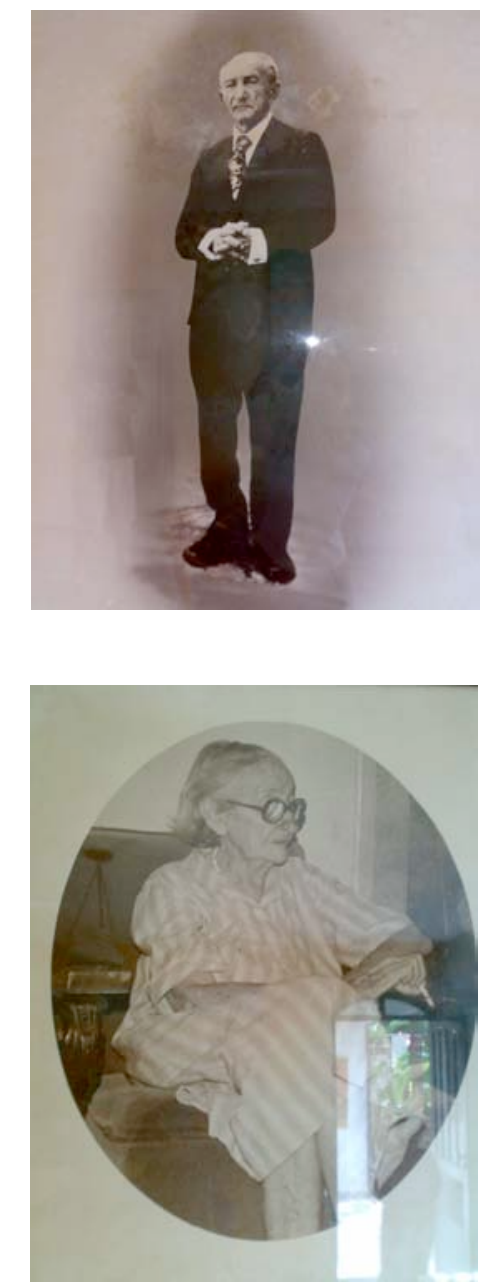
sala, um com a foto de José Alves Ramalho, o Avôhai, e outro com a de Maria Soledade Pordeus Ramalho. E a conversa girou em torno de um álbum de recortes que ela havia deixado no hotel para eu ver e das histórias que ela contou e das que ela não contou na carta que deixou junto. 
João Pessoa, 05 de fevereiro de 2010.

Cara Christina,

Tentei me comunicar com você por telefone, mas não consegui. O funcionário do hotel onde está hospedada comentou que você estaria em uma excursão à Pedra do Ingá. Concluí que não retornará tão cedo e decidi, então, escrever esta carta. Não sei quanto tempo mais ficará na cidade, portanto, caso a gente se desencontre, pelo menos farei minha parte te ajudando em sua pesquisa sobre o meu sobrinho. É um bom exercício para minha memória, que dizem ser uma das melhores da familia. Pensei em fazer isso por e-mail, afinal, tenho gostado bastante de me comunicar com essa rapidez que a internet nos propicia. Mas, como vou pedir a Christian para deixar na recepção do hotel o liuro de colagens de matérias jornalísticas, filipetas e tudo que coletei sobre Zé ao longo dos últimos anos, achei que seria mais interessante você recebê-lo junto com algo escrito. Assim, aproveito também para relembrar os tempos em que ele se correspondia conosco através de cartas. Ele já te contou que, nessa época, ele nos escrevia, mas não nos lia? Não vou dizer que sinto saudades, porque deve ter sido uma das fases mais angustiantes dessa história que você deseja contar. Vou te explicar por quê, mas, antes, quero falar um pouco da nossa familia, que foi a base de tudo, o pilar que deu a ele a força para correr atrás do sonho.

Meu pai era hipertenso, mas a vida foi muito boa para ele. Era um homem forte e enérgico, mas muito calmo. Quando passou mal, não tardou a falecer. Tinha olhos azuis, uma cor de azul diferente. Quando ele olhava, a gente já sabia o que ele queria. Era poeta e escreveu um livro só de sonetos, mas não cantava, apesar de gostar muito de música. A pessoa mais desentoada que eu já vi na minha vida foi meu pai! Ele admirava Roberto Carlos, tanto que profetizou o sucesso dele e o de Garrincha. Ele não era Pelé, não! Eu sou igual a mamãe, mas nisso eu puxei a ele: eu também gostava de Garrincha! Sou flamenguista. Zé não tem time. Christian e Antônio são doentes por futebol e ele diz que a culpa é minha. Foi da familia da minha 
mãe que ele puxou esse talento para a música. Eram todos muito musicais e o pai dele, quando jovem, era seresteiro no sertão. Tocava bem demais e tinha uma voz linda aquele meu irmão! Pena que morreu tão jovem... Era boêmio, mas no bom sentido, tipo Vinicius de Moraes.

Antônio Pádua Pordeus Ramalho era o nome desse meu irmão. Éramos sete, três homens e quatro mulheres. Meio a contragosto da familia dela, Antônio se casou com Estelita, que era professora. Quando eles se separaram, ela foi para Recife levando Goretti, a irmã de Zé, que nasceu em 14 de dezembro de 1950. Os dois nasceram em Brejo do Cruz, mas Zé ainda morou em Teixeira e em Campina Grande antes de chegar em João Pessoa. Meus pais sempre diziam para ele: "Vá ver sua mãe!" Ela sempre vinha aqui buscar Zé e trazia Goretti e, na medida em que foi crescendo, ele foi ganhando autonomia para ir a Recife sozinho visitar a mãe e a irmã. $E$ passava temporadas lá. O pai faleceu em Teixeira, para onde fomos depois do tempo que vivemos em Brejo. Parece confuso, né? Mas é que somos de várias cidades do interior. Meu pai era agente fiscal do Estado e se mudava muito. O filho mais velho dele, o Ze Ramalho que era jornalista, nasceu em Sousa. Depois, veio Maria Madalena, nascida em Patos. Antônio, pai de Zé, e Raimundo Nonato também nasceram em Patos. Minhas irmãs Teresa e Inês, minha mãe deu à luz em Teixeira e eu, em Piancó. Nós conhecemos quase todo o sertão da Paraíba.

Teixeira fica na serra, perto de Patos, e é um lugar muito alto. Como meu pai tinha problema de pressão, o médico achou melhor ele sair de lá. Fomos para Campina Grande em 1955. Em 1962, viemos definitivamente para João Pessoa. Acho que a morte do meu irmão também foi motivo para a familia querer sair de Teixeira. Tinha um açude enorme no sítio e Antônio foi atravessá-lo depois de apostar com um amigo quem chegava primeiro na margem. Acabou em tragédia. Em 1953, não tinha autópsia no sertão, mas um farmacêutico disse que foi o coração. Eu era pequena, mas lembro da cena: mamãe e papai loucos na beira do açude. Quando Zé chegou de Campina Grande, onde estava com minha irmã, o pai já tinha sido enterrado. Foi em janeiro, Zé tinha três anos e, a partir desse momento, ele nunca mais quis sair de perto do avô, o meu pai, que, vendo o filho ir embora, adotou-0, entregando-se de corpo e alma à criação do primeiro neto. 
Meu pai se chamava José Alves Ramalho, um dos meus irmãos era José Pordeus Ramalho Filho e Zé foi o segundo José Ramalho Neto, porque o primeiro nasceu morto, em 1948. Estelita ficou grávida, mas o filho nasceu morto. Quando veio o segundo, em 1949, meu irmão Antônio disse que ia colocar Zé Ramalho de novo e meu pai disse: "Não faça isso!" Mas ele colocou mesmo assim. Depois, veio Goretti, que também não existe mais. Faleceu em maio de 1991, vítima de um câncer que foi rápido demais, e deixou dois filhos. Sofremos muito a perda dela. Ela tocava um violão delicioso e era amiga de verdade. Goretti e Zé nunca me chamaram de tia porque, na verdade, fomos sempre muito amigos. Minha idade eu não vou contar. Não gosto de falar da nossa diferença porque essas ideias são sempre coisas da nossa cabeça. Foto, também não vou tirar. Acho que foto deixa uma marca que você não apaga mais. Mas, mudando de assunto, você viu o filme de Elinaldo? Ali tem uma boa parte dessa história que você quer saber. Ele me perguntou por que eu não tenho muitos recortes sobre os anos 1980 nesse livro que estou emprestando a você. Dessa época, não gosto de falar. Essa história de quando ele se afundou nas drogas, foi acusado de plágio e ficou sem dinheiro, eu não vou contar. Tanto que não tenho nada da imprensa daquela época. Quando tive a ideia de fazer esse álbum, eu decidi só colocar os sucessos. Para mim, essa é a história dele. Portanto, não me pergunte mais nada sobre isso. Se você quiser saber, veja o filme. Lá, é ele mesmo quem comenta essa fase. Ele diz: "Eu saí, desci, fui lá embaixo, minha cadeira ficou desocupada, mas voltei com força e estou aqui com vocês."

Meu pai era tão louco pelo Zé que, todo ano, eles acendiam juntos a fogueira de São João no dia 24 de junho. Em 1975, Zé foi viajar pelos interiores da Paraíba e de Pernambuco e nada de voltar. Meu pai, sentado na cadeira de balanço, com o rádio ligado, de bonézinho e fumando o cachimbo, foi enfático: "Só acendo essa fogueira quando Zé chegar!" E, já de noite, Zé chegou dizendo: "Vôzinho, cheguei! Viajei em cima de carro, caminhão e o diacho para chegar até aqui e acender essa fogueira com você." Meu pai era muito católico e colocou Zé para ser coroinha aqui na Igreja Nossa Senhora de Fátima, em Miramar, com o Padre Eurivaldo Tavares. 
Ele ia todo final de semana à missa, tocava matraca e chegava em casa declamando trechos em latim. Acho que foi por causa dos meus pais que Zé se casou na lgreja.

Papai e mamãe tiveram muito a cabeça no lugar e criaram Zé muito bem, com a ajuda da minha irmã Inês, que o levava para o colégio, em Campina Grande, e acompanhava ele nas aulas, estudava junto. Teresinha era doida por Zé porque, em 1962, o filho dela morreu. Tanto que, quando ele se casou com Ísis, ela deu um andar da casa dela para eles morarem. Zé te disse que eu ajudei a criá-lo, mas a minha participação era mais na diversão. Eu gostava de Jerry Adriani, Wanderley Cardoso... Roberto Carlos eu sempre gostei menos, não sei por que. Na época, eu acompanhava tudo! Fazia camisa, boné, as coisas iguais aos Beatles para eles usarem nos shows. Quando viemos morar em João Pessoa, Zé fez 14 anos aqui e Ernesto, o marido de Teresinha, deu o primeiro violão a ele. A familia nunca castrou Zé. Quando resolveu largar a faculdade de Medicina, ele falou para meu pai: "Se não fizer isso, vou ser um músico frustrado." E meu pai respondeu: "Eu não criei um homem para ser frustrado. Vá em frente, mas você sabe o que vai enfrentar. Você é nordestino e, lá, vai precisar tomar o lugar de alguém, porque não tem um lugar reservado para você. Agora, seja honesto". E Zé nunca saiu da linha, está na canção "Eternas Ondas": "Devorando árvores, pensamentos, seguindo a linha."

Agora que reparei que o seu nome tem H como o do filho mais velho do Zé. Quando Zé se separou legalmente de ĺsis, sua primeira mulher, uma artesã maravilhosa, ele trouxe Christian e Antônio para morar aqui com a gente. Mas não quero falar do divórcio, não, que ocorreu em 1984, quando ele ainda não tinha condição de levá-los para o Rio. Quando Zé foi para o Rio pela primeira vez, tinha só o Christian. Aí, ele voltou e nasceu Antônio. Só que ele se separou logo, porque já estava apaixonado por Amelinha. Christian e Antônio tem uma diferença de quatro anos e Antônio é só um ano mais velho que João, o primeiro filho de Zé com Amelinha. Tem ainda Maria Maria, irmã de João por parte de pai e mãe, e os filhos de Zé com Roberta, José e Linda. São todos muito amigos. Antônio sempre diz que eles são todos tão unidos que parecem filhos da 
mesma mãe. Isso sempre foi coisa do pai: todas as férias, Zé junta os meninos todos na sua casa de Areia Dourada, uma praia perto de Cabedelo.

Há três familias Ramalho no interior, uma no município de Conceição, a outra em Teixeira e a de Brejo do Cruz. Naquele festival do Maracanãzinho, Zé apresentou Elba Ramalho ao Brasil como sua prima do coração. Acho que se dizem primos porque são parentes longe, tão longe que nem sabemos o grau de parentesco. Ah, mas o que é que tem dizer que são primos mesmo não sendo? Nada demais, né?

Percorrendo o caminho de Zé Ramalho em memória e tentado o transpor para esta carta, acabo de me dar conta de que sua viagem a Ingá do Bacamarte deve ter a ver com o início do percurso que 2 é fez até alcançar o sucesso. Acabo de sentir um frio na espinha. Olha, ainda estou à disposição para a entrevista que você queria fazer comigo, mas não me peça para comentar essa passagem da vida dele. É outro assunto que não coloquei no meu álbum e sobre o qual não gosto de falar: a Pedra do Ingá. Eu tive muita pena porque o "Paêbirú" não foi bem divulgado na época. Meu pai falou que Zé devia ir conversar com o secretário de Educação, porque estavam lançando na mesma época um selo com a imagem da pedra que inspirou o Zé e 0 Lula Côrtes na gravação do disco. Mas não deu resultado nenhum. E aí aconteceu aquela tragédia na Rozenblit... Na época, ninguém se interessou pelo assunto. Também não quero falar sobre a versão pirata que um selo da Alemanha fez sem pedir autorização ao Zé nem sobre a briga dele com Lula, que parece que aconteceu porque ele autorizou a cópia do disco sem o amigo saber. Não adianta insistir. Essa história eu não vou contar.

Acho que comecei a escrever essa carta pensando em relembrar os tempos em que Zé nos escrevia e a gente ficava à espera de uma ligação para podermos responder às questões que nos enviava. Ele tinha mais ou menos a sua idade quando foi para o Rio. Você está com 29, né? Acho que ele tinha 25 ou 26. Meu pai faleceu naquele mesmo ano e minha mãe disse a ele: "Meu filho, não passe fome!" Minha mãe era sertaneja mesmo, de um povo arraigado que entende o que é passar fome. Zé respondeu a ela: "Mãe, cuide de Christian e de Ísis e me deixe." E foi com a 
cara, a coragem e o matulão. Ele passou horrores entre 1976 e 1978, mas não nos dizia nada. E poderíamos ter ajudado de alguma forma, mas ele nunca quis. Ele escrevia cartas lindas! Nos aniversários, era cada uma mais bonita que a outra. Mas Zé não tinha endereço, como é que íamos enviar correspondências? Até que, numa noite, eu estava com minha mãe e o telefone tocou. Ela atendeu e ficou muito nervosa: "Eu não estou entendendo... É meu filho que está falando? Atende, Zélia!" Peguei o telefone e era Zé: "Zélia, sou eu. A avó está nervosa, mas sou eu ligando para dizer que já tenho endereço." Eu dei um grito e e ele continuou contando notícias boas: "Estou contratado, meu disco vai sair. Avisa aí ao pessoal que por esses dias eu vou aparecer no Fantástico". A gente enlouqueceu. E, logo depois, começou a aparecer notícias dele e de "Avôhai". Todo mundo que viajava me ligava para dizer que tinha escutado a música. Os amigos iam trazendo os recortes de jornais e revistas que encontravam pelo caminho e eu comecei a montar este álbum. Até que o sucesso de Zé chegou aqui. Toda a verdade do trabalho de Zé Ramalho está aqui no meu liuro. Você não acha importante ver uma coisa dessa? Eu digo sempre que a cada álbum ele se supera. Mas minhas músicas preferidas não são as de sucesso. Do primeiro disco dele, por exemplo, fico com "Adeus segunda-feira cinzenta". Eu ando fazendo um levantamento das que gosto mais para o Christian preparar um disco para mim, que vai ser o meu álbum preferido de Zé e, assim como esse livro que te empresto - mas peço que me devolva antes de voltar para o Rio -, vai conter a minha verdade sobre a obra do meu sobrinho.

Bom, Christina, gostei de escrever essa carta. Me fez lembrar de muita coisa boa. Espero que volte de Ingá disposta a me responder. Pode ser por carta, e-mail ou telefone. Melhor vai ser se puder me encontrar lá em casa amanhã, depois, quando quiser. Acho que não te falei sobre tudo o que precisa saber... Mas lembre-se que há histórias que não vou contar.

Um abraço,

\section{Zélia Pordeus Ramalho}




\section{O Carnaval do amor e de Lula Côrtes}

Ah, o carnaval pernambucano de $2010 \ldots$ Ah, os dias que o anteciparam e os que o sucederam... Aquela semana que começou no 09 e terminou no 18 de fevereiro deve ter sido uma das mais mágicas que vivi em toda a minha vida. $\mathrm{E}$ não foi só porque conheci Marco, um paranaense que mudaria os rumos da minha história pessoal, como todo mundo pensa que foi quando falo que o estado natal de Alceu Valença, Geraldo Azevedo e tantos outros nomes da música brasileira tem a melhor folia do Brasil. E nem teve a ver com o fato de Zé Ramalho ter feito um show magnífico no Marco Zero no domingo, emocionandome mais do que de costume, visto que eu estava mais do que nunca imersa em suas canções. Sei que não tenho propriedade para comparar essa com as outras festas, afinal, não conheço todas. Mas estou acostumada com a do Rio de Janeiro e já fui duas vezes na da Bahia, estado que também adoro, mas que, na minha opinião, tem um carnaval muito industrializado. Em Pernambuco, a folia é democrática mesmo, com blocos de rua em Olinda e shows em palcos espalhados por toda Recife, tudo de graça. É uma delícia poder escolher o que ver e conferir o que escolheu com tranquilidade, em um clima familiar.

Chegando lá, encontrei Gabriel Rached, um grande amigo que conheci na viagem a Cuba e que se tornou um dos meus maiores parceiros, na alegria e na tristeza. Naquele momento, Gabito era a companhia ideal, afinal, eu andava alternando euforia e depressão, vivendo o momento triste da separação e, ao mesmo tempo, empolgada com os rumos do meu novo projeto profissional. Ficamos em uma daquelas casas que grupos alugam em Olinda e dividem entre os hóspedes. Na nossa, 40 pessoas dividiam três banheiros e dormiam em seus colchões amontoados em um só cômodo. Dormíamos tarde, após os shows, e acordávamos cedo, com o batuque dos blocos. Mesmo com todo esse desconforto, eu me diverti. A única desvantagem foi, pela falta de segurança, ter que passar o carnaval inteiro carregando a mochila com meu gravador, caderno 
de pautas, agenda de telefones e encartes de discos de Zé Ramalho. Com meu material de trabalho sempre nas costas, fiz como Mário: "Desde que cheguei ao Rio disse aos amigos: Dois dias de carnaval serão meus. Quero estar livre e só. Para gozar e para observar." (ANDRADE, 2001, p. 46) De fato tirei dois dias só para mim, só que eu queria estar livre para trabalhar.

Já no primeiro dia, em Olinda, passei a manhã com Raul Córdula, pintor, artista gráfico e crítico de arte paraibano que foi amigo de Zé Ramalho e fez alguns dos cartazes de shows que o músico apresentou na Paraíba, entre eles o "Atlântida", além de ter criado os cartazes que traziam Zé como modelo de uma marca de roupas de couro chamada Curral. Na quintafeira, dia 11, começou minha história de amor com Marco, que veio a se tornar meu marido

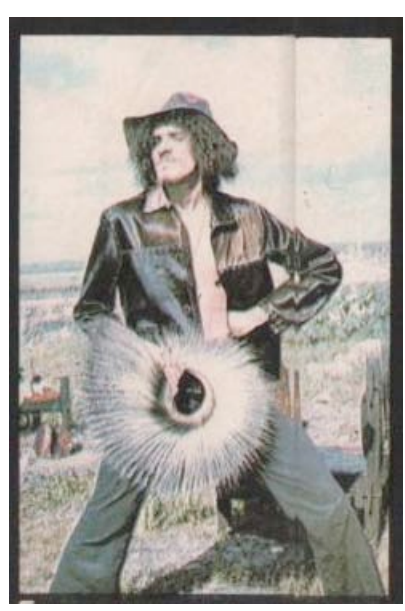
três anos e meio depois. Ele dançou rapidamente comigo e com Gabriel no show de Alceu, na abertura do carnaval de Olinda, e conversou comigo no dia seguinte, na abertura do carnaval de Recife. Reencontramo-nos na madrugada de terça para quarta-feira, no último show do festival de rock alternativo RecBeat, onde finalmente nos beijamos. Na quarta-feira de cinzas, tive a oportunidade de passar quase um dia inteiro com Lula Côrtes, o parceiro de Zé em "Paêbirú - Caminho da montanha do sol", o LP duplo que, a essa altura, estava valendo aproximadamente $\mathrm{R} \$ 5$ mil.

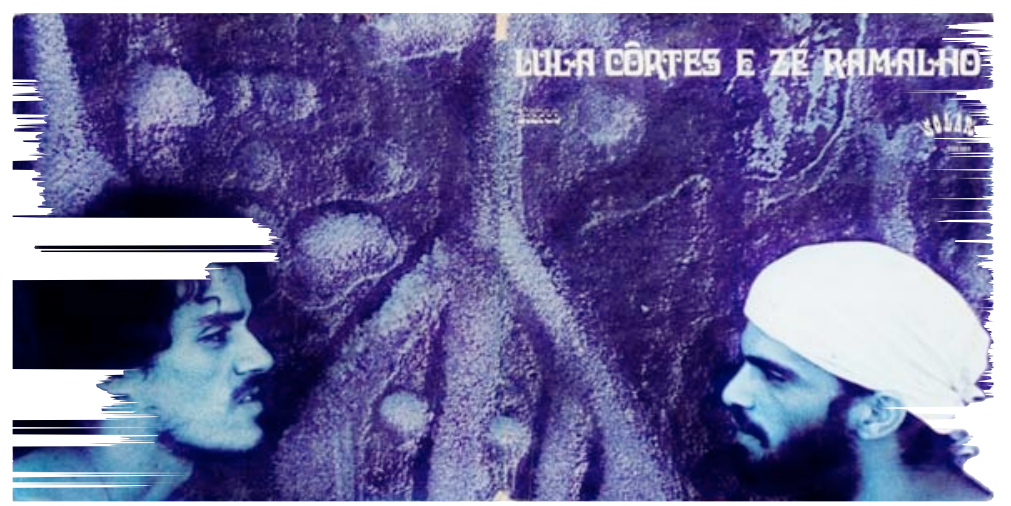


Músico e artista plástico, naquele momento, Luiz Augusto Martins Côrtes, o Lula Côrtes, estava ocupando o cargo de diretor de Cultura na secretaria municipal de Cultura de Jaboatão dos Guararapes. Em 1972, ele gravou com Laílson, hoje cartunista renomado em Recife, o LP "Satwa" pela Rozemblit e, um ano depois, produziu e fez a arte da capa do álbum "No sub reino dos metazoários", de Marconi Notaro. Ao lado de Zé, fez alguns shows após a gravação de "Paêbirú" e integrou a banda de Alceu no "Vou danado pra Catende", mas acabou se afastando do grupo ao preferir se dedicar às artes plásticas em Pernambuco, ao lado de sua mulher, Kátia Mesel. Eu sabia que ele e Zé não se falavam e que a briga não tinha acontecido na época em que trabalharam juntos, mas ainda não tinha descoberto o motivo da confusão. Quase todos escorregavam quando o assunto era esse. Ou me contavam suas versões dos fatos. Uns diziam que Zé tinha ficado chateado ao saber que o álbum foi reeditado pelo selo inglês Mr. Bongo e, depois, pelo alemão Shadoks sem sua autorização. E, mais ainda, quando soube que não levaria vantagem financeira, visto que os direitos de comercialização do produto passaram a ser da Polydisc depois que o selo de João Florentino - pernambucano de Caruaru que era vendedor em uma loja de discos na década de 1970 e virou um dos maiores empresários do ramo - comprou todo o acervo da falida Rozenblit. E havia quem defendesse a teoria de que o músico famoso se recusou porque seu rosto aparece na contracapa e não na capa, como o de Lula. Amigos mais próximos de Lula comentavam que a renda obtida com a negociação de "Paêbirú" tinha sido destinada ao tratamento de Lula contra um câncer. Nas entrevistas que dá, Zé se limita a comentar que não acha importante relançar um trabalho que não teve o menor valor na época em que foi gravado. Já alguns dos profissionais da indústria discográfica que trabalham ou trabalharam com Zé contam que ele ficou bravo em 1993, durante a gravação do CD "Cidades e lendas", porque Lula pediu dinheiro em troca da liberação da música "Não existe molhado igual ao pranto", uma parceria da dupla composta para a seção Terra do "Paêbirú". Nessa época, Zé ainda estava tentando se reerguer da fase ruim e aceitou gravar o novo disco sem nenhum investimento da sua gravadora. Tanto que a grana para Lula saiu do bolso do próprio artista. Zé contou com a ajuda de muitos amigos, inclusive de Sivuca, e assumiu produção, direção de estúdio, 
arranjos, convites a músicos, tudo. Assim que "Cidades e lendas" ficou pronto, a Sony o dispensou e, para compensar, deu-lhe as fitas master para que ele pudesse negociar com outra empresa. Zé só conseguiu lançar o disco em 1996, quando foi convidado pela BMG a gravar "O grande encontro" com Alceu, Elba e Geraldo e negociou sua participação no projeto em troca de oportunidade de lançar seu disco solo.

Mas muitas dessas histórias eu não ouvi nessa minha primeira investida em Pernambuco, não. A cada viagem à terra de Lula, eu encontrava um dos personagens dessa saga e ouvia uma versão diferente. Com a morte de Lula e a recusa de Zé em explorar o assunto mais profundamente, decidi que ia incluir no livro tudo o que transcrevi das entrevistas que fiz, deixando para o leitor a tarefa de ponderar. A conclusão que eu tirei foi a de que tanto Lula quanto Zé não são pessoas fáceis. Lailson mesmo me contou que, após a gravação de "Satwa", outro disco que acabou editado pelos selos estrangeiros, ele passou tempos sem falar com Lula devido ao descaso do parceiro em um momento em que, para o projeto ser reconhecido, era necessário esforço dos dois. A um parceiro profissional de Zé, perguntei se, na época do "Cidades e lendas", ele não poderia ter ligado para Lula para conversar sobre a situação financeira em que estava. Afinal, o pernambucano pediu a recompensa a um funcionário da editora ligada à gravadora, provavelmente acreditando que, por se tratar de uma multinacional, havia uma verba para o projeto, como sempre aconteceu na história da indústria discográfica até o início da crise causada pela pirataria. Minha fonte perguntou: "E você não conhece o Zé? Orgulhoso como é, você acha mesmo que ele ia ligar para o Lula, que também não era um cara fácil?"

Essa foi a primeira e a última vez que estive com Lula, que vinha lutando contra um câncer na garganta há mais ou menos cinco anos. Treze meses e alguns dias depois do nosso encontro, em 26 de março de 2011, ele faleceu aos 61 anos. Fiquei triste com a notícia, afinal, apesar de não me contar a história completa da briga, ele foi um doce comigo desde a resposta ao primeiro contato que fiz, por e-mail. Fora isso, eu ainda tinha alguma esperança de tentar reaproximá-lo de Zé Ramalho, o que era muito desejado por ele. Acho que, 
sentindo uma boa vibração em mim, menos de um mês depois da entrevista, Lula enviou-me um e-mail pedindo ajuda para levar o ex-amigo a sua cidade.

De: Lula Côrtes

Para: Christina Fuscaldo

Enviadas: Quarta-feira, 3 de Março de 2010 17:58

Assunto: Zé Ramalho

Olá, Christina! Como vai?

Aqui é Lula Côrtes e eu gostaria que você mandasse o seu número ou me ligasse. 0 secretário de Cultura de Jaboatão dos Guararapes, Ivan Lima, está com um grande interesse em trazer Zé Ramalho para o Festival Cultural da Pitomba, na verdade a Festa de Nossa Senhora dos Prazeres em sua $353^{a}$ edição, um ponto alto da cultura pernambucana. Certamente seria muito enriquecedora a presença de um ícone da música nacional como Zé Ramalho. Gostaríamos que você estreitasse esse contato. Caso você pudesse entrar em contato com o secretário, eu the agradeceria profundamente. Caso possa mandar o telefone de Zé para ele, seria muito importante, pois eles conversariam diretamente. Envie para ele meus votos de sucesso sempre.

Obrigado e conto com você!

Lula Cortes.

Eu respondi assim que eu pude, claro, sem dar a Lula o telefone de Zé Ramalho. Uma regra no Jornalismo é nunca passar o contato direto da fonte. Mas não deixei minha outra fonte na mão: passei o de Otto.

De: Christina Fuscaldo

Para: Lula Côrtes

Enviadas: Segunda-feira, 8 de Março de 2010 11:44

Assunto: Res: Zé Ramalho

Olá, Lula! 
Para falar sobre contratação de shows, Zé tem um empresário chamado OHo Guerra. Vou te passar o e-mail e os telefones dele em outra mensagem. Posso passar o recado e avisar de que o secretário vai entrar em contato com o OHo. O que você acha? Vale a pena dizer que você está envolvido no projeto? Se quiser me ligar, fique à vontade.

Um beijo grande,

Chris

Lula Côrtes nunca mais me respondeu, mas, no fim do ano, eu soube que Zé Ramalho tinha sido contratado para fazer o show da virada na praia de Candeias, perto de onde o ex-parceiro morava. Não sei até hoje - confesso que nunca achei importante apurar - se ele passou os contatos do Otto que enviei à produção ou se o secretário de Cultura chegou a Zé Ramalho por outros meios. O que ficou claro para mim foi que o evento não reaproximou a dupla. Tentei puxar o assunto "Lula" em um e-mail que enviei a Zé logo após seu falecimento, mas, em sua resposta, não houve menção a ele. Eu obtive muitas versões da história, mas nunca consegui arrancar dele o porquê de tanto rancor.

De: Christina Fuscaldo

Para: Zé Ramalho

Enviadas: Terça-feira, 29 de Março de 20ll 15:40

Assunto: Lula e projeto

\section{Oi, Zé! Tudo bem?}

Recebi a notícia da morte do Lula Côrtes no fim de semana. Estive com ele em Recife no ano passado e, logo depois, recebi um e-mail em que pedia para que eu 0 ajudasse a estreitar um contato com você para falar de uma possibilidade de show em Jaboatão dos Guararapes. Passei o contato de OHo, mas ele nunca mais respondeu. Naquele e-mail, ele finalizava com a seguinte frase, direcionada a você: "Envie para ele meus votos de sucesso sempre." Como 2010 foi para mim um ano de muitas mudanças, dificuldades e viagens, não consegui te mandar 0 recado. Meio abalada, envio agora. 
Sabe, Zé, eu entendo sua mágoa. Ou raiva. Não sei, afinal, qual sentimento ficou em relação a Lula e gostaria, principalmente agora, que você me dissesse. Mas insisto em tentar entender porque você faz de "Paêbirú" um tabu. Acho pouco democrático, inclusive, porque a minha geração quer saber mais sobre esse disco. Eu, hoje, acordei ouvindo os lados "Terra" e "Ar", inspirada pelo mapa astral que fiz recentemente. Já te falei que sou Virgem, com ascendente em Touro e Lua em Gêmeos, ou seja, Terra, com Terra e Ar? Sabe, Zé, nossos ouvidos estão querendo escutar e eu só sou uma privilegiada porque encontrei a versão editada pelo selo inglês em vinil em uma loja de Greenwich Village, em Nova York. Paguei apenas US $\$ 40$ pela raridade, acredita? Para mim, essas reedições também são raridades. Por que você insiste em renegá-lo?

Mudando de assunto, gostaria de conversar com você novamente sobre nosso projeto. Ano passado fiz algumas coisas por ele e fui procurada por muitas editoras pequenas e também por editoras online. Fui incisiva com todas, dizendo que minha maior preocupação é a distribuição. Sempre digo aos editores que uma biografia de Zé Ramalho não pode não chegar ao Nordeste. E aí todos acabam com medo de assumir a responsabilidade. As editoras grandes andam com medo de biografias, mas algumas seguem conversando comigo. O problema é que elas não garantem um adiantamento ou algo que possa me permitir me dedicar ao trabalho de pesquisa. Falo de grana mesmo. Infelizmente, preciso trabalhar em muitas coisas para pagar as contas. Introduzi o assunto para dizer que estou preparando um projeto para inscrever na Lei Rouanet. Ou para pedir ajuda a empresas da iniciativa privada ou a órgãos do governo ligados à cultura. Se conseguisse investimento, poderia mergulhar no liuro e entregar para editoras que querem vê-lo pronto. Gostaria de saber o que acha disso tudo.

Nesse projeto, incluí uma parte interativa. Hoje, acho que é necessário algo mais do que apenas o livro. Pensei em um hotsite lque pode estar dentro do seu site, dentro do site de alguma editora ou mesmo ser independente) com um blog no qual eu escreveria textos sobre sua história em primeira pessoa, como se você estivesse contando. Também pensei em incluir vídeos, trechos de shows seus, entrevistas com você etc. Eu iria editando e alimentando esse site e, paralelamente, 
inspirando-me nesses textos para escrever o liuro (um romance em terceira pessoa). Mas isso são ideias, algumas já no papel. Pra mim, é muito importante você gostar delas também. O que me diz? Um abração,

Chris

Fiquei com medo de o assunto "Lula Côrtes" aborrecer Zé Ramalho, mas eu não podia deixar de tentar, ao mesmo tempo em que aproveitei a mensagem para debater os rumos do mercado de livros no Brasil e sondar se meu biografado compraria uma parte dessa briga que eu vinha tendo com as editoras. Zé me respondeu com doçura, sugerindo que eu não usasse seu site, por ser uma plataforma de pesquisa e não de interação, mas me incentivando a continuar: "Contudo, acho que você poderia também tentar uma editora nordestina, da Paraíba ou de Pernambuco... Talvez seja um novo caminho para chegar ao seu objetivo. O problema do advance será encontrado em todas as suas tentativas, mas a persistência e a certeza do que você está realizando não devem the fazer desanimar." Ele chamou-me por Chris e assinou Zé Ramalho, desejando sorte para mim, ou melhor, para minha faceta blogueira. "Boa sorte para a GarotaFM!" Foi assim que ele se despediu. O assunto "Lula" morreu. $\mathrm{Na}$ última resposta que enviei, contei a ele que tinha estado na Paraíba mais uma vez, em maio de 2010, para cobrir um festival de cultura e para tentar articular novos contatos para a biografia, mas que não havia tido boas notícias em relação ao mercado editorial de lá. E sondei se ele estava sabendo sobre o projeto da Legião Urbana que finalmente havia sido lançado em meados de 2010 e que me rendeu elogios de jornalistas em suas matérias de divulgação do relançamento dos discos. Mas esse e-mail ficou sem resposta. 


\section{A peleja da biógrafa com o mercado editorial}

Em 2011, o mercado jornalístico estava sendo tomado ao mesmo tempo que derrubado pelas redes sociais. Quando mandei esse e-mail para Zé, eu tinha acabado de desistir da vida de freelancer por um tempo e de assumir o cargo de subeditora do portal Globo Cidadania, que abarcava os sites de assuntos relacionados a cidadania de programas da TV Globo. Na verdade, desde que saí do site da Infoglobo, eu vinha fazendo muitos trabalhos de conteúdo para redes sociais, tanto que, um ano depois, em julho de 2010, Valquíria Daher, editora da Megazine, revista semanal do jornal O Globo voltada para jovens, convidou-me a voltar para a empresa temporariamente porque sua editoria tinha acabado de colocar um site no ar, estava implementando uma conta no microblog Twitter e precisava de alguém experiente em comunicação nas redes para ajudar a aumentar o número de seguidores. Foi uma experiência e a realização de um sonho: lá atrás, quando comecei a trabalhar na empresa, meu maior objetivo era assinar matérias na Megazine. Comecei a sedução quando ainda estava no Extra e a editora na época, Adriana Barsotti ${ }^{24}$, abriu as portas pra mim e comprou minha primeira sugestão, uma matéria em primeira pessoa - o que no Jornalismo dizemos que é estilo gonzo ${ }^{25}$, mas eu hoje chamo de autobiográfica - que contava a minha experiência em Cuba. Fiz outras reportagens nos quase três anos seguintes e foi por isso que Valquíria, subeditora que assumiu o lugar de Adriana, confiou que eu faria um bom trabalho. Meu contrato durou seis meses e eu tinha uma certa liberdade para seguir tocando meus frilas ${ }^{26}$ e articulando minhas viagens a trabalho ou para visitar meu namorado, Marco, que seguia morando em Curitiba naquele primeiro

24 Após mais de 20 anos trabalhando no jornal O Globo, a jornalista foi dedicar-se à academia. Mestra e aluna da primeira turma de doutorado em Comunicação Social da PUC-Rio, ela conquistou o Prêmio Compós de Dissertações 2013 com o trabalho "Transformações contemporâneas nas práticas jornalísticas: o jornalista on-line como mobilizador de audiência, que mostra as novas experiências de produção de informação na internet".

25 Gonzo é um estilo de narrativa em que o narrador abandona a objetividade e se mistura com a ação. O originador do estilo foi o jornalista americano Hunter S. Thompson.

26 Gíria para freelancer. 
ano em que cursava um mestrado em Ciência Política ao mesmo tempo em que administrava sua empresa de tecnologia. Ficamos um ano e meio nessa peleja depois que, como aconteceu com Mário após o carnaval do Rio, "não perdi a máquina fotográfica, antes cinematográfica de meu subconsciente. Aqui estou na vida quotidiana. Pois não é que ontem começaram a se revelar fotografias e fotografias dentro de mim!" (ANDRADE, 2001, p. 47).

Meus dias estavam atribulados, com tanta coisa para dar conta e ainda me alternando entre noites na casa dos meus pais, em Niterói, e outras no apartamento de Roberta Pennafort, amiga que morava sozinha e, após minha separação, alugou-me um quarto, onde fiquei durante esse período em que estava em busca de um apartamento. Sentia-me como Graciliano, que, após sair da cadeia, foi morar em uma pensão: "Estou inteiramente acostumado com essas mudanças complicadas a que me tenho submetido ultimamente. Creio que se adormecesse aqui hoje e amanhã despertasse na China, não me admiraria." (RAMOS, 2011, p. 46) Logo que meu contrato no jornal O Globo terminou, fui com Marco e dois amigos, Rodrigo e o editor de vídeo Pedro Palmeiro, ao Fórum Social Mundial no Senegal, onde prestamos serviços e vivemos mais uma experiência daquelas! Assim que voltamos, fui chamada para o cargo de subeditora na empresa $\mathrm{H}_{+}$, que prestava serviço para as Organizações Globo. Nesse tempo todo, eu ligava para imobiliárias, agendava visitas a apartamentos, tentava negociar os que eu mais gostava, mas os preços no Rio de Janeiro só subiam após o anúncio de que a cidade sediaria a Copa do Mundo em 2014 e as Olimpíadas em 2016. Consegui finalmente dar uma entrada no meu lar, pegar um financiamento e me mudar em abril de 2011 para um aconchegante dois quartos no Bairro de Fátima, no Centro do Rio. A corrida passou a ser por mais trabalhos, afinal, eu tinha que pagar a papelada da compra, as parcelas altas $e$ todas as contas. Para minha sorte, em julho, Marco pegou férias na empresa, veio escrever sua dissertação no Rio, para poder passar mais tempo comigo, e acabou recebendo uma proposta de trabalho que fez ele se mudar para minha casa e reorganizar toda a sua vida. Nessa mesma época, passei 40 dias seguidos viajando junto com uma equipe do Criança Esperança, capturando histórias, fotos e vídeos em instituições apoiadas pelo projeto da TV Globo, e 
mais um mês dedicada ao trabalho nos bastidores do programa. Não fiz novas entrevistas durante todo esse período, mas, mesmo em meio a tantos afazeres, eu vivia pedindo aos amigos contatos de editores para poder enviar meu projeto. Numa dessas conversas, acabei sendo entrevistada por Leonardo Lichote para uma matéria de capa do Segundo Caderno, do O Globo, sobre o filme do Cristiano Bastos, que estava prestes a ser lançado, em que o jornalista aproveitava para chamar a atenção para o problema que eu estava enfrentando:

\begin{abstract}
Uma trajetória que Christina pretende detalhar em sua biografia, atualmente em fase de coleta de depoimentos e pesquisa. Ela tem a carta branca do compositor, que entregou em suas mãos todo o seu arquivo pessoal. A autora destaca assim como Elinaldo e Cristiano - a força do mito de Zé Ramalho e o tamanho de seu público espalhado pelo Brasil, mas tem dificuldades para encontrar uma editora interessada. "Um editor chegou a me dizer que Zé Ramalho venderia apenas dois livros", conta. "Sua vida é riquíssima, única, assim como seu caminho na MPB."27
\end{abstract}

Record, Rocco, Companhia das Letras, Editora Globo, Zahar, Casa da Palavra, Primeira Pessoa, Sextante, Objetiva e Ediouro novamente... E eu não só enviava e-mails e telefonava como, de vez em quando, conseguia convencer um editor a me receber para uma reunião. Mas, entre uma frase e outra das que figuravam as respostas, um certo preconceito em relação à biógrafa e ao biografado acabava vazando. "Zé Ramalho vai vender dois livros", falou-me um editor, do outro lado da linha. "Acho o seu projeto legal, mas por aqui a gente só costuma fazer biografia de nomes mais conhecidos", escreveu-me

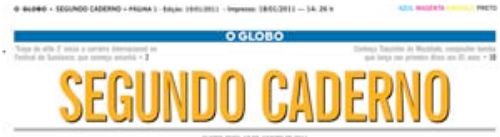

\section{Psicodelia à brasileira}

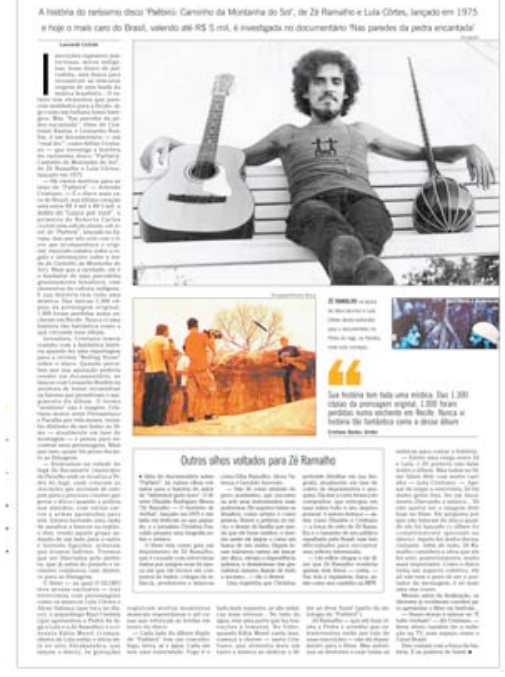
outro. Eu mandava o projeto e era como se

27 LICHOTE, Leonardo. Psicodelia à brasileira. Segundo Caderno, O Globo, Rio de Janeiro, 19 jan. 2011, p. 1. 
eles não dedicassem cinco minutos à leitura. Eu pensava como Mário: "Não me conformo com a maldade e estupidez humana." (ANDRADE, 2001, p. 50). E, como Graciliano, eu considerava desistir: “...depois, quando tiver lutado muito tempo e quando me sentir inteiramente desanimado. Se assim acontecer, arribarei daqui para a Palmeira, vou aprender a comprar couros e nunca mais hei de abrir um livro" (RAMOS, 2011, p. 45) Um deles não poupou grosseria e deixou bem claro que meu currículo e todo o meu esforço para fazer um bom projeto não valiam nada: "Olha, não acredito que uma grande editora tope fazer este livro em parceria com você. Imagine o grande número de excelentes propostas de livros prontos que recebemos. Seria contraproducente investir em um projeto de livro do qual não temos a menor garantia de que sairá um ótimo trabalho. Veja, não é desconfiança em relação à história ou ao seu texto. Mas as editoras só costumam topar este tipo de parceria com escritores já consagrados, e mesmo assim, de vez em quando, quase raramente." No final, ele se despedia me pedia para compreender. Escrevi-Ihe uma carta.

Rio de Janeiro, 3 de outubro de 2011.

Caro Sérgio,

Obrigada pelo retorno. Não faz muito tempo que as editoras apostavam, sim, em novos autores. Cheguei até a sua editora por indicação de duas amigas que foram contratadas por você. Vou seguir tentando finalizar o projeto. Foi bom receber sua mensagem, porque pelo menos tirei aquela ideia da cabeça de que o projeto estava estacionando nas pessoas que trabalham com você.

Abs,

C.F. 


\section{Missão dada é missão cumprida}

Nem meu currículo nem as indicações de amigos um pouco mais próximos das pessoas nas quais eu precisava chegar estavam me ajudando. É claro que pensei em desistir. Pensava como Mário: "É coisa que passa, mas ando tristonho. Que diabo! A gente admira uma pessoa e quer mostrar como sente essa pessoa e não pode. Parece castigo de Deus." (ANDRADE, 2001, p. 45) Fui para aquela sala de cirurgia no dia 19 de dezembro de 2011 avaliando tudo o que tinha vivido até ali e como eu gostaria de seguir vivendo caso eu saísse com vida daquela clínica. Eu não estava me expondo a nenhuma operação de risco, mas, como a de desvio de septo casada à rinoplastia era a primeira da minha vida e como eu carrego alguns dos mesmos medos que minha avó de quase 100 anos me ensinou a ter - e um deles é de médico, apesar de o meu avô fazer parte desta categoria -, eu não tinha tanta certeza de que ia ficar tudo bem. No mesmo dia, com a cara toda enfaixada e a narina cheia de gases, fui para meu repouso domiciliar ainda refletindo sobre meus sonhos. Trabalhando muito para a $\mathrm{H}+$ como prestadora de serviço, eu não queria mais atuar nesse formato. Mas o que eu ia fazer, se o projeto para o qual vinha dedicando paralelamente também não me garantia nenhum retorno e, o pior, ainda precisava de investimento? Pensava como o Graciliano de Silviano: "Em princípio, o intelectual devia viver da renda que seus livros lhe auferem, mas aqui esse dinheiro é minguante e chega mais espaçado do que qualquer salário." (SANTIAGO, 2013, p. 36) Só que eu nem era ainda uma escritora... Muito menos uma intelectual! Fiquei entre a cama e o sofá de casa por sete dias. Sem acesso à rede, a jogos ou a qualquer outra diversão alienatória devido ao furto do meu smartphone na semana anterior, só me restava pensar nas ideias que passavam pela minha cabeça e debatê-las com Marco, que pediu umas folgas para poder me fazer companhia depois que minha mãe, que segurou a barra mais pesada nos primeiros dias, teve que voltar para Niterói. 
A história da Lei Rouanet, eu e Marco chegamos a começar a tocar, mas acabei desistindo depois de procurar e não encontrar uma pessoa que aceitasse ser minha parceira e assumir a captação de recursos caso o projeto fosse aprovado. Sozinha, eu não conseguiria fazer isso, afinal, essa não é a minha área de atuação. Disse a meu namorado, então, que não queria mais sofrer assim e que estava de mau com meu mercado de trabalho. Avisei que passaria o ano juntando todo dinheiro que sobrasse para, em 2013, ingressar no mestrado e migrar para a carreira acadêmica. Ele defenderia sua dissertação em junho de 2012 e, a essa altura, eu estava encantada com suas pesquisas dedicadas a outra área, porém de um aprofundamento que, no Jornalismo, só acontecia quando eu produzia reportagens especiais, como algumas que fiz para a Rolling Stone. O tema, eu ainda não sabia, mas com certeza exploraria algo em torno da biografia de Zé Ramalho, afinal, eu não ia jogar tudo o que tinha coletado até ali no lixo. Dessa forma, encerraria esse ciclo e transformaria meu caso de amor e ódio com o gênero biográfico em um trabalho acadêmico. Eu só pensava que tinha que reagir. Levantei a cabeça, mesmo com a cara inchada. Na volta ao trabalho, perto do Ano Novo, se trocasse o "ele" por "ela" e "dona Nair" por "dona Orita" ou por "Cornelinho", eu poderia dizer que a análise de Paula Dip não era sobre Caio Fernando Abreu, mas sobre mim:

Ele sempre teve uma altivez, atávica, que herdou de dona Nair: não perdia a elegância nem quando estava na pior. Aliás, era justamente quando estava por baixo que ele ia buscar lá no fundo de sua alma aristocrática uma força vinda não se sabe de onde, para dar a volta por cima. (DIP, 2009, p. 164)

Naquela virada para 2012, eu pediria forças para juntar a quantia necessária para meus estudos nos dois anos seguintes e, claro, para ser aprovada na seleção da pós-graduação do curso que eu ainda estava para escolher. Como eu não sabia ainda como dizer a Zé Ramalho que não escreveria mais o livro, decidi esperar o melhor momento. Mas, para ele não desconfiar da minha mudança de planos e para tentar arrancar algumas informações que eu precisaria para escrever o projeto com o qual eu entraria na disputa por uma vaga na universidade, enviei uma carta bem diferente das 
anteriores. Agora, eu começava a questionar coisas que não entendia e, ao mesmo tempo, percebia que, como jornalista, não faziam diferença. Eu me dei conta de que, ao escrever matérias, muitas informações eram apenas traduzidas para a língua dos veículos. Para o mestrado, no mínimo, eu tinha que compreender as questões, principalmente porque, lá, eu precisaria discuti-las.

Rio de Janeiro, II de janeiro de de 2012.

Oi, Zé! Tudo bem?

Hoje é aniversário de 61 anos do meu pai e faltam II dias para completar 13 anos que te ouvi pela primeira vez. Adoro dias, meses e anos ímpares, pois sempre acho que esses números me dão sorte. Hoje, quando me dei conta do 61 , do $\|$ e do 13 , pensei muito no início da minha história com sua música e no que fez eu querer me aproximar de você. Refleti muito sobre o que me atraiu em sua produção musical. Lembrei que foi a questão do hibridismo, o que eu sempre senti que tinha também em mim, ou melhor, em minha lista de preferências. Acho que já te falei que meu pai é roqueiro, mas, agora, mais do que nunca, sei que o rock que ele ouviu e ouve até hoje em Niterói é o mesmo que você escutou na Paraíba. Eu descobri que, por mais que meu pai não compartilhe certas referências comigo, ele tem outras também muito diversificadas que absorveu dos pais e até da irmã dele, minha tia Auxiliadora. Meu avô Cornélio gostava de ouvir discos de bandas marciais e era fã de Vicente Celestino, mas, olha que engraçado, a única atração que 0 fazia parar de ler seu jornal para prestar atenção na televisão era Secos \& Molhados. Minha avó vivia tocando samba, bolero e tango ao piano enquanto minha tia estudava música clássica e amava Elvis Presley. Dulce, a empregada doméstica, passava o dia atenta às rainhas do rádio Emilinha e Marlene e aos cantores Orlando Silva, Nelson Gonçalves e Cauby Peixoto, esses últimos paixões de Dona Orita também. É claro que, assim como ficou na memória, muito disso 
deve ter ficado também nas entranhas do meu pai. Tanto que, quando mais nova, fiquei meio chateada de ele não ser tão fã de sua obra quanto eu, mas hoje eu percebo que ele adora quando eu toco uma canção sua ao violão ou mesmo quando escuto o som perto dele. Acho que nunca te disse que "Admirável gado novo", inclusive, passou a ser uma que apresentamos em dueto - ele no violão e eu na voz - em saraus de amigos. O que me fez achar que ele não estava atento a você foi o fato de não saber o que me falar sobre o artista que eu acabara de descobrir e queria tanto desbravar. Também, pudera: 13 anos se passaram e nem eu sei tanto assim sobre você, afinal, como eu já disse antes, diversas vezes, não há material suficiente disponível para pesquisa.

Tem uma coisa que me intriga, uma pergunta que eu preciso fazer: o que fez com que sua música se tornasse essa mistura hibrida que agrada a tanta (e tão diversa) gente? 0 que te atravessou primeiro e o que você permitiu que te atravessasse depois? Perdão se te questiono de maneira brusca ou se pareço muito direta, mas não estou conseguindo me conter diante dessa dúvida. Parece boba, mas vou te provar que não é. Essa pesquisa está quase me deixando louca! Acalme-se, que estou sendo meio apocaliptica, mas é só porque ultimamente tem sido difícil entender uma das fases da sua vida: a sua iniciação na música. Faz dias que, incessantemente, ouço discos seus em casa e no carro e, a cada momento, encontro uma nova referência. Tentei buscar respostas nas entrevistas que fiz para o livro e as opiniões são muito diversas - e muitas vezes divergentes - sobre sua composição. Há quem diga que a base da sua música é o forró. Tem os que acham que é com os repentes do sertão a sua grande identificação. Muitos acreditam que o rock foi o que te tocou primeiro. E sobrevivem os que crêem que uma força do além comanda seus registros mais internos e dá conta de manter sua alma conectada a uma música que vem de outro universo (ou outras dimensões). Difícil para esses é explicar que dimensões são essas e que tipo de instrumento os habitantes tocam por lá. Será que você também acredita nisso? Eu, particularmente, sei que tudo isso e mais o folk, o pop e a música que aconteceu no Brasil durante o Tropicalismo estão em você. Sei também que a questão folclórica, a relação com a literatura de cordel e, consequentemente, com os cantores, aboiadores e repentistas que (re)conheceu em suas 
viagens ao sertão - e incluo o prefixo "re" na palaura "conheceu" porque me parece meio óbvio que, até completar cinco anos, idade que tinha quando saiu de Teixeira, você teve algum contato, mesmo que indireto, com essa cultura - estão no seu sangue. Mas o que chegou primeiro? O rock promoveu o despertar de um cordelista/repentista adormecido desde sua primeira infância ou foi essa literatura simples e direta, com suas rimas pobres e temas tão comuns do cotidiano sertanejo, que te levou a abrir o coração para o encantamento por um ritmo tão revolucionário, mas, ao mesmo tempo, tão singelo e colorido por palauras tão bobas? Farei algumas perguntas que podem te ajudar a pensar na questão: se você, quando pequeno, não tivesse saído de Brejo do Cruz ou de Teixeira, que tipo de música estaria tocando hoje em dia? E, se não tivesse sido levado para a capital da Paraiba na adolescência, o que acha que teria absorvido em Campina Grande?

Acho que não serei demagoga ao afirmar que o Brasil tem a música mais misturada do mundo. Para começar, é só constatarmos que somos o maior país da América Latina. Mas isso não é tudo. Os Estados Unidos também são grandes e não são tão criativos quanto nós. Talvez a geografia física explique: com tantos tipos de clima, relevo e vegetação, nunca seríamos iguais uns aos outros. Talvez a geografia social ajude: com uma concentração maior da riqueza em certos estados, não teria como uma música soasse como a outra, ainda mais com toda a opressão da alteridade. Por fim, acho que há ainda a questão da identidade que cada indivíduo forma ao longo de sua existência. Temos um povo muito diversificado. Acho isso tão lindo... Tenho certeza de que é o que faz os estrangeiros se apaixonarem por nós, nossas cidades e nossa música.

Escrevendo, conjecturando, criando um debate, acabei me dando conta de que talvez não haja uma resposta para a pergunta que te faço nesta carta angustiante e angustiada. Mas, falando em hibridismo, lembrei de uma palaura que Jorge Mautner adora pronunciar e que, no sentido que ele usa, explica bem o que somos: uma "amálgama". Sim, é isso! Você é uma amálgama que chegou na cidade grande com todo o folclore e adjacências do interior em seu sangue, porém adormecidos, e só viu suas raízes despertarem quando entrou em contato com o que veio do outro lado do mundo, com uma cultura que te atraiu por algum motivo. Deve ter sido essa a inspiração 
para a composição de "Amálgama", que está no seu disco "Força verde"... Não interessa aqui buscarmos entender por que o rock te chamou atenção, porque para certas coisas não há explicação. Voltando, então, a Jorge Mautner, agora ficou mais fácil entender a sintonia que vocês têm desde quando se conheceram. Sim, claro! Acabo de me lembrar de uma conversa que tive com ele em que perguntei-the se você, Zé, é uma amálgama. Quer saber o que ele respondeu? "Total! Inclusive, ideologicamente. O Ze traz em si uma herança cultural riquíssima... É a sua própria essência." Perguntei, Zé, se ele sabia que você tocava músicas de Caetano e Gil quando ainda fazia shows na Paraíba. "Sim, mas a admiração é mútua!", exclamou ele. Você lembra de quando se encontrava com Mautner constantemente? Enquanto ele me contava, eu ficava tentando me transportar de alguma forma para o início da década de 1980, quando vocês se conheceram, e para o Hotel Meridien ou para a casa onde você morou com Amelinha em Fortaleza, locais onde os dois se reuniam e passavam horas em debates em torno de questões políticas, ideológicas e culturais. É muito interessante pensar nessa química que surgiu entre você, um sertanejo com pouca experiência pelo mundo, mas com muita vivência de sua própria realidade, $e$ ele, um filho de uma iuguslava católica (Anna Illichi) com um judeu austríaco (Paul Mautner) que cresceu frequentando cerimônias do candomblé com sua babá (Lúcia), aprendeu a tocar violino, fundou em 1956 o partido do Kaos (movimento artístico-literário voltado à discussão de questões ligadas à cultura brasileira) e virou escritor, compositor, poeta, músico, mas, sobretudo, um homem livre. $E$ isso aconteceu na vida dele bem antes de acontecer na sua. Mesmo assim, Mautner viu em você um ser mitológico dentro da música popular brasileira. Veja bem o que ele me disse: "O Brasil foi construído pelos escravos e os índios, durante os quatro séculos de escravidão. E isso tudo se reflete no Nordeste, então, a ligação mitológica que o Zé Ramalho tem com tudo isso, porque a visão dele de tudo já é mitológica, porque é a visão mais profunda. Para você ter uma ideia, em 1956, eu já tinha o partido do Kaos, que durou até 1962 com 3 mil partidários seguindo essa amálgama, que é o multiculturalismo e a multidiversidade. Nós temos essa amálgama. E a visão mitológica é tão grande que, quando eu entrei para o Partido Comunista, a visão que o pessoal do 
Centro Popular de Cultura (órgão ligado a UNE) era a de que nem o surrealismo nem o cubismo nem nada poderia retratar o novo ser humano, só uma nova mitologia. E o Zé se insere nisso por natureza: ele vê as coisas através da mitologia, ele tem aquela visão mais abrangente de tudo. Para mim, foi isso que fez com que parecesse que nos conhecíamos há mil anos."

Para mim, está muito bem explicado... A questão agora, é entender porque, com tanta leitura e cultura, Jorge Mautner se vestiu de "Aladim" e, junto a Robertinho do Recife, gravou em 1981 o (hoje) hilário clipe "Encantador de Serpentes", fazendo a cobra sair de um cesto de palha. Você que trabalha com Robertinho desde 2002 faria o favor de perguntar a ele o que significou aquilo? Morro de rir toda vez que assisto ao vídeo, mas acabei me esquecendo de perguntar ao Mautner. Aliás, engraçada demais também é a história das fotos da capa do seu quinto álbum, "Orquídea negra", que você e ele fizeram em Búzios: como assim chicotear o fogo ateado à água da praia? Frederico Mendes, o fotógrafo, contou-me que vocês esperaram até 4h para começar o ensaio, você e Mautner embalados pela inseparável cocaína e ele tendo que tomar banho gelado para se manter acordado e com o olhar atento à melhor luz. Disse também que comprou dois galões de gasolina para promover a queima e que jogava o combustível na água e, em seguida, 0 fósforo aceso. Durante nosso papo, ele gargalhou ao lembrar que, no momento em que a chama acendia, Mautner assistia à cena e ele berrava para você: "Levanta o chicote!" Na contracapa deste disco estão você e Mautner, de mãos apertadas, celebrando a amálgama.

Bom, Zé, mesmo depois de eu mesma conjecturar muitas coisas sobre esse hibridismo que caracteriza sua produção musical, adoraria ler suas considerações sobre a questão que abordo nesta carta. No mais, como ainda não nos falamos em 2012, feliz Ano Novo.

Beijos e abraços,

Chris Fuscaldo 


\section{A nova parceria com Zé Ramalho e a mudança de rumo}

Zé não me respondeu e, mais uma vez, fiquei com a sensação de que ele é que havia desistido de mim. Ou será que estava achando que fiquei louca, afinal, eu não tinha ainda começado as entrevistas com ele e já queria que me desse depoimentos profundos? Eu lembrava que nosso combinado era eu só adentrar sua intimidade depois que tivesse assinado contrato com alguma editora, mas, como havia conseguido furar o cerco em vários momentos, essa tinha sido só mais uma tentativa. Segurei minha ansiedade e segui vivendo o meu dia a dia de prestadora de serviço como subeditora do portal Globo Cidadania, de editora do blog GarotaFM e de produtora de releases para gravadoras. Eu só não corria mais atrás de editoras. E, agora, cada minuto da minha vida era alimentado pelo desejo de mudança. Zé que me desculpasse, mas, novamente sentia-me como Mário: "Me parece mesmo que além das doenças físicas estou de novo com um grande cansaço intelectual." (ANDRADE, 2001, p. 66) Ralar e não ter nenhum retorno não estava sendo fácil. Só que o cansaço durou pouco. E a ideia de não escrever mais o livro, também.

Um dia pela manhã, quase chegando em meu trabalho, no Leblon, esbarrei com Zé e Roberta: eu andava em direção ao prédio e o casal seguia para a praia para sua caminhada diária. Tudo o que eu não desejei foi esse encontro, pois não queria falar sobre o assunto "biografia". Para minha sorte, os dois não perguntaram nada. Apenas me cumprimentaram e quiseram saber de mim. "Chris!", exclamou Zé: "Como você está?" Respondi que estava bem e disse para onde ia. Desvencilhei-me deles e fiquei refletindo sobre o que aquilo poderia significar, afinal, em um ano e pouco fazendo esse mesmo trajeto todos os dias no mesmo horário, tinha sido a primeira vez que isso acontecia. E olha que, além de morarem a dois quarteirões do edifício da $\mathrm{H}_{+}$, eles costumam ser metódicos em sua rotina. Um mês depois desse episódio, recebi uma ligação de Otto dizendo que passaria meu telefone para Roberta, pois ela queria falar 
comigo. Gelei. Será que a mulher de Zé ia me colocar contra a parede? O que eu ia dizer se ela perguntasse sobre os rumos da biografia? Que nada! Muito elegante e discreta, a esposa ligou para me convidar para escrever o release do novo disco de Zé Ramalho. "Sinais dos tempos" foi o primeiro CD lançado pelo Avôhai Music, selo do próprio artista, e trazia canções autorais que faziam muitas reflexões sobre tudo o que Zé viveu e produziu ao longo de seus 63 anos. Era seu primeiro álbum de músicas inéditas desde "Parceria dos viajantes", aquele para o qual trabalhei, em 2007. Em 2012, estava fazendo cinco anos que virei parceira de Zé Ramalho e que ganhei dele a autorização para a escrita da biografia. Tratava-se de um número ímpar. Será que isso também era um sinal dos tempos, algo me dizendo que não era para eu desistir? Lembrei de uma passagem do livro de Janet Malcolm sobre Sylvia Plath em que a jornalista diz que o biógrafo é apresentado como uma espécie de benfeitor porque "sacrifica anos de sua vida no trabalho, passa horas intermináveis consultando arquivos e bibliotecas, entrevistando pacientemente cada testemunha." (MALCOLM, 1994, p. 16). Para ela, o leitor acredita estar "vivendo uma experiência literária elevada" e não "ouvindo mexericos de bastidores" quando percebe que o biógrafo se dedicou para valer, sem deixar nada a fazer por sua pesquisa. Se eu ainda queria ser uma biógrafa, eu precisaria fazer o mesmo, ou seja, seguir me sacrificando em prol de um bom resultado. Dei-me conta de que eu estava fingindo estar bem quando, na verdade, não andava feliz longe das minhas fontes e das pesquisas. Confirmei mais uma vez que, como o Graciliano de Silviano, eu sou movida à paixão:

Só compreendo o fazer como paixão: qualquer atividade (seja trabalho ou prazer) deve ser feita com paixão. Com paixão, entrego-me a todas as formas do fazer: fazer das engrenagens íntimas (os intrincados mecanismos do corpo humano, sua higiene diária); o das atividades prazerosas (a comida, a mulher, o cigarro e a aguardente); o fazer profissional (este escrever, por exemplo); o fazer mais nobre que é o de transformar o homem e a sociedade num homem menos sofrido e numa sociedade mais justa. Tudo isso feito com paixão. (SANTIAGO, 2013, p. 75)

Se ainda me restava alguma dúvida, Zé tratou de me dar a resposta, sem saber de nada, concedendo-me, por telefone, uma entrevista longa e detalhada sobre seu novo trabalho, só que alternando informações novas com a narração 
de episódios antigos e tornando, assim, a nossa conversa mais uma compilação de histórias importantes para minha pesquisa. As reflexões de Zé sobre cada tema que eu abordava em nossa conversa, essas que não tinham espaço no texto que eu faria para a imprensa ler, foram o que me fizeram querer retomar o projeto. "Procurei puxar as lembranças e vivências. Muitas vezes acho mais interessante que as pessoas, ao ouvirem, façam sua própria interpretação. Sei que sairá uma visão diferente da minha. Isso me diverte", disse Zé para mim logo no início do papo. Brinquei, dizendo que, para o livro, ele terá que ser um pouco mais objetivo do que quando compõe, afinal, não posso escrever uma biografia em que minha interpretação de histórias mal contadas dê o tom.

Quando perguntei sobre a faixa-título, senti Zé me dando um recado: "Houve um momento em que chorei colocando a voz em 'Sinais dos tempos'. Lembrei de várias coisas que aconteceram na minha vida. Há uma crueldade em relação à maquina do mundo, em relação às pessoas que trabalham como artistas. Atores, cantores, compositores, escritores. Recorrendo novamente ao Dylan, 'tá tudo mudando e eu não alcanço mais'. Eu conseguia tocar nas coisas, hoje em dia tudo é muito rápido e cruel. Difícil alcançar algo só com sua pureza, porque você precisa produzir e se inspirar nesse mundo louco para fazer sua obra de arte. Temos que ter muita fibra para trabalhar num mundo com tanta concorrência." Será que ele tinha refletido sobre a minha dificuldade em alcançar meu objetivo e estava sugerindo que, além de manter minha pureza, eu devia prestar atenção nas mudanças do mundo?

Achei interessante Zé Ramalho compor uma música chamada "Olhar alquimista" depois de eu, com a ajuda de Jorge Mautner, entender que esse é o seu papel na música brasileira. Sem saber que um ano depois ficaria entre a vida e a morte, comentou a passagem também nessa canção: "O refrão da música são visões pós-morte. Tem várias historias bonitas sobre a passagem. Há uma curiosa especulação e eu penso muito nisso. Não que eu me sinta perto de morrer, mas acontece naturalmente." Sem conhecer Janet Malcolm e sem ter lido em seu livro o trecho em que ela considera voyeurismo o que motiva os autores de biografias, ele se uniu a mim também na função de voyer, sendo que o meu desejo é bisbilhotar a vida dele enquanto o dele, na canção "O começo da 
visão", é olhar pelo buraco da fechadura para ver, com todo respeito e romantismo, uma mulher: "Nessa música, eu tive uma intenção meio sacana de colocar o voyerismo. Fala sobre o homem que se esconde pra enxergar a mulher. O romantismo é uma coisa presente no meu trabalho, na minha forma rude de ser romântico. Eu tenho um romantismo rudíssimo. Você não vai encontrar, em uma composição minha, 'eu te amo', apesar de eu ser considerado um cantor romântico. E eu continuo sendo romântico sem falar nada disso. Tenho um jeito rude de falar de amor e de desejo. Aprendi isso com o Pink Floyd. Eles também não usam esses termos, mas falam dessas sensações."

Identifiquei-me imediatamente: eu também não sou uma romântica típica, mas não o deixo de ser. Gosto de escrever, mas sem melar o papel. Adoro a companhia do homem amado, mas não o tempo todo e naquele grude comum aos casais apaixonados. Eu sonho, mas com objetivos. Aproveitando a cumplicidade, Zé me contou mais uma história, acontecida 35 anos antes, quando ele já estava no Rio de Janeiro: "Nessa música, eu cito Carlos Drummond de Andrade, que é meu ídolo, porque lembrei de quando, atravessando uma pista depois de tomar um LSD, fomos tirar uma pedra do caminho e, quando a jogamos, quebrou uma tubulação e ficou jorrando água. Fiquei me sentindo tão culpado." Depois de tanta conversa, culpada estava eu. Como eu podia ter pensado em desistir? Enviei o release para Roberta, administradora do Avôhai Music, que o utilizou no lançamento do disco, em julho, e aproveitei para pedir informações que usaria, futuramente, no livro.

\author{
De: Christina Fuscaldo \\ Para: Roberta Ramalho \\ Enviadas: Segunda-feira, 23 de Abril de 2012 16:34 \\ Assunto: Release
}

Oi, Roberta! Tudo bem?

Fiz um release. Gostaria que você e Zé dessem uma olhada e me dissessem se gostam do formato e se aprovam tudo o que usei no texto. Nossa conversa foi muito profunda e fiquei na 
dúvida sobre expor ou não certas questões. Mas como o Zé dá poucas entrevistas, entregar o ouro pode ser bom para a divulgação (muitos jornalistas podem aproveitar o material). Qualquer consideração, mandem para que eu faça a alteração. Aqui, algumas perguntinhas para confirmar o conteúdo. Mais abaixo, o primeiro corte do release.

- A briga na justiça começou em $2005 ?$

- Nasceram netos nos últimos 5 anos?

- Vocês podem conferir a grafia de trechos de músicas que cito?

- Vocês podem confirmar se os nomes da Banda 2 são Chico Guedes (contrabaixo), Edu Constant (bateria), Dodô de Moraes (teclados), Toti Cavalcanti (sopros), Zé Gomes (percussão) e Zé Leal (cajon)?

\section{Zé Ramalho - Sinais dos Tempos}

"A maturidade traz nostalgia e a consciência do caminho percorrido. Como disse Bob Dylan em uma entrevista, 'já passei da metade da minha vida'. E eu me sinto assim: depois da metade do caminho, vendo tudo o que aconteceu. 'Sinais dos tempos' é o disco da minha maturidade."

Zé Ramalho não fazia questão de ser compreendido, quando mais jovem, pleno de energia para experimentações. Com "Sinais dos tempos", surge uma diferença fundamental na vida desse cantor-compositortocador-trovador. O novo álbum está repleto de letras, melodias e harmonias feitas na medida para torná-lo um sujeito mais admirado mesmo por quem ainda não havia captado, até agora, as deixas para compreendê-lo. Muito da vida e da obra de Zé estão nas novas músicas.

Não! Definitivamente, o músico paraibano radicado no Rio de Janeiro desde a década de 1970 não se aproveitou do "eu te amo" nem rimou "amor" com "dor" em seu primeiro disco de inéditas desde 2007, quando lançou "Parceria dos viajantes". Em "Sinais dos tempos", basta um mínimo de sensibilidade para perceber sentimentos bastante profundos em versos 
como: "O tempo vai passando e com ele eu vou", que abre a música "Indo com o tempo"; e "Não deixo para trás nada do que eu sou", a última frase dessa primeira faixa do álbum. Ouvindo com a "maturidade" que ele cita na declaração acima, é possível esbarrar com um Zé Ramalho que deixa suas entranhas à mostra também nas outras onze canções do repertório desse CD cem por cento autoral.

"Depois que passei dos 60, parece que os anos estão indo mais rapidamente. $O$ tempo corre mais ligeiro e isso me lembra muito a canção dos Rolling Stones "Time is on my side". Me vejo num mundo louco, rápido e cruel e tendo que me inspirar nele para fazer minha obra de arte. Os fãs vinham cobrando um disco autoral, mas passei os últimos cinco anos refletindo sobre mudanças que ocorreram e fazendo músicas aos poucos. Sinais fala sobre isso e me emociona muito. Espero que consiga passar essa emoção para as pessoas. Teve um momento em que chorei durante a gravação da voz, lembrando de várias coisas”, diz Zé.

Os últimos cinco anos foram revolucionários para Zé. Desde 2005 lutando na justiça para poder gravar seus próprios sucessos, um imbróglio que envolvia o artista, sua antiga gravadora e a editora que detinha os direitos autorais de suas músicas, Zé Ramalho saiu vencedor, porém cansado. O sentimento veio à tona durante a composição de "Indo com o tempo": "E não perdoarei a quem me trouxe dor." E foi expurgado quando Zé se deu conta de que tinha em casa uma parceira para uma nova empreitada fonográfica: com a esposa, Roberta Ramalho, criou o selo Avôhai Music, voltado para o lançamento de seus próprios trabalhos e que estreia com "Sinais dos tempos". Ainda durante o período de reflexão, Zé celebrou o nascimento de netos. E homenageou Bob Dylan, Beatles, Luiz Gonzaga e Jackson do Pandeiro em tributos discográficos. Esses nomes e outros voltaram a influenciar Zé em solos, palavras e atitudes nesse disco.

"Estou falando do que vivi. Estão no álbum lembranças e vivências, algumas de forma mais aberta e outras mais enigmáticas", avisa.

Com o Pink Floyd, Zé Ramalho aprendeu a falar de amor sem usar os velhos jargões. "É como se toda vez que você se lembra de quando perdeu sua virgindade / Doces quimeras de rapaz, de moça donzela ou 
solteira", diz ele em "Lembranças do primeiro", que traz ainda uma citação a outro ídolo, Carlos Drummond de Andrade: "No meio do caminho há um pedra. Deixe-a, não a remova". A frase é resultado da lembrança de um episódio que viveu na há mais de 35 anos, quando, ao retirar uma pedra do meio de uma estrada para evitar um acidente automobilístico, acabou causando um transtorno. A rocha rolou e bateu em uma tubulação, que estourou e ficou jorrando água durante horas.

Zé abusa da psicodelia, disseminada na década de 1970 pela banda progressiva Pink Floyd, também em "Olhar alquimista". Enfeitada pelo lapsteel de Phil Braga, parceiro de seu filho João Ramalho na banda JPG, a música proporciona sensações do além bem ao estilo David Gilmour em "Echoes". Ao mesmo tempo em que vagueia por histórias de sua vida ("Não foi como nós planejamos, mas fugiu do nosso controle"), a letra também remete à morte: "Aonde me viram não mais verão os alquimistas e anciões".

"A morte é uma coisa sobre a qual já comecei a pensar. Ela está também na primeira faixa, quando canto: 'Será que chegarei à terra prometida ou atravessarei o túnel de luz'. Não que eu me sinta perto de morrer, mas tenho uma curiosa especulação", comenta.

Já "A noite branca" foi composta para fazer um contraponto com a pesada e lisérgica "A noite preta", última música do primeiro disco de Zé, lançado em 1978 com "Avôhai" e outros sucessos. A nova canção fala de um delírio de amor em uma noite linda. Na introdução, um ryff inspirado no hit "Venus", da banda setentista Shoking Blues, que o músico tocava em seus tempos de baile. Depois do rock, a música entra no frevo agalopado, para Zé Ramalho não perder o costume, com metais feitos pelo arranjador Toti Cavalcanti. Zé toca toca violão em todas as bases.

Referências e lembranças do passado estão em diversas canções de "Sinais dos tempos". A inspiração em "A terceira lâmina", sucesso de Zé de 1981, aparece em "Lembranças do primeiro" e em recortes harmônicos de "Olhar alquimista". O sentimento de saudade está evidente em "Rio / Paraíba", na qual homenageia os dois estados, o natal e o que o acolheu, porém atendo-se a falar do Rio Paraíba, que banha a Paraíba. Esta 
música também remete à aceleração do tempo: "O calendário resumiu-se a quase um mês", canta Zé.

"Sinais dos tempos" conta ainda ainda com a psicodélica "O que ainda vai nascer", que traz elementos de "Beira-mar", outro sucesso de Zé, lançado em 1979; o xote "Um pouco do que queira"; a mística "Portal dos destinos"; o "bolero" político "Justiça cega", na qual Zé Ramalho vomita reflexões sobre a justiça; e "O começo da visão", uma canção cheia de latinidade sobre voyeurismo, que tem guitarra de Rick Ferreira e vocalizes de Roberta de Recife. Pai da cantora e parceiro de Zé há 15 discos, Robertinho do Recife gravou guitarra em "Sinais dos tempos" e trouxe do Mississipi, onde participou de shows, Jessie Robinson para gravar em "Indo com o tempo", canção que o guitarrista estadunidense reconheceu como um verdadeiro blues, apesar dos elementos de MPB e de Nordeste.

“'Sinais dos tempos' é um álbum para pessoas que estavam aguardando novas produções musicais minhas, sem maiores pretensões. É a continuidade do meu trabalho, minha leitura do mundo atual e minha maturidade como homem e compositor. É a vontade de continuar levando essa vida de shows, estúdio, gravações e de oferecer o que crio", anuncia.

Formada por Chico Guedes (contrabaixo), Edu Constant (bateria), Dodô de Moraes (teclados), Toti Cavalcanti (sopros) e Zé Gomes (percussão), a Banda $Z$ está em todas as músicas do álbum, totalmente produzido e dirigido por Zé Ramalho e Robertinho do Recife. Com o verso lisérgico "tudo que sonhei atravessa o cristal", "Anúncio final" tem como objetivo, sem delongas, encerrar o disco e colocar um ponto nas reflexões:

"Há uma crueldade em relação à maquina do mundo hoje, com toda essa correria. Recorrendo novamente a Dylan, na letra de 'Things have changed', tá tudo mudando, mas não deixo para trás nada do que eu sou."

Aguardo retorno.

Um abraço,

Chris Fuscaldo 
Novamente Zé me mostrou que respeitava o meu trabalho, não sugerindo nenhuma alteração além da correção de um nome que escrevi de forma errada.

\author{
De: Roberta Ramalho \\ Para: Christina Fuscaldo \\ Enviadas: Segunda-feira, 23 de Abril de 2012 17:20 \\ Assunto: Re: Release
}

OiChris,

A reunião atrasou e aproveitei para te responder.

- A briga na justiça começou em $2005 ?$

Sim. O juiz da 10a. Vara Cível sentenciou a favor do Zé em agosto de 20ll. Está em fase de apelação para o TJ-RJ (2a. instância);

- Nasceram netos nos últimos 5 anos?

Sim, os dois filhos do Christian (filho mais velho), Maria Luísa (3 anos) e Felipe (l ano). Os outros netos são mais velhos: Ester (12) e Miguel (7), filhos da Maria Maria, e Ana Lua (10), filha do João, estes são netos dele com a Amelinha. A Maria Luísa e o Felipe são netos com a Ísis.

- Vocês podem conferir a grafia de trechos de músicas que cito?

Sei que este "aonde" está gramaticalmente incorreto, deveria ser "onde", mas ele fez assim e ficou... Embora anciãos = anciões = anciães, ele prefere "anciões".

- Vocês podem confirmar se os nomes da Banda 2?

Todos estão certos, menos Zé Leal, que nem é da banda nem está no disco. Também não tem cajon no disco.

O nome do músico americano é Jesse Robinson e não "Jessie", como está no release. Fora isso, no mais, está tudo ok. Release aprovado.

Bjs,

\title{
Roberta
}




\section{A experiência autobiográfica de outros}

No mesmo mês do lançamento de "Sinais dos tempos", disco que acabou tendo boas críticas, mas repercussão pequena na mídia - acredito que devido ao fato de Zé Ramalho, mais uma vez, ter escolhido apenas dois veículos para dar entrevistas e não ter montado um show específico com canções do álbum viajei novamente com a equipe do Criança Esperança para produzir mais uma leva de vídeos e matérias para o site do projeto. $\mathrm{Na}$ volta, conheci o professor doutor e pesquisador Júlio Diniz em um evento musical produzido por ele junto à Prefeitura de Niterói. Percebi que o universo acadêmico poderia ser transposto para fora das universidades. Até ali, eu acreditava que mestrado e doutorado só servia para quem queria dar aula. E não que eu também não quisesse isso: tinha me apaixonado pelo ofício ao ser convidada duas vezes, em 2011 e em 2012, para assumir a frente de uma sala de aula em duas universidades particulares do Rio nas quais um amigo jornalista lecionava. Mas eu também queria continuar escrevendo livremente para o meu blog, produzindo artistas, bandas e eventos musicais, pesquisando para projetos de gravadoras e de artistas independentes e, acima de tudo, trabalhando para a edição da biografia de Zé Ramalho. Júlio me convidou para conversarmos com calma na Miranda, casa de shows onde, dias depois, ele produziria um evento com Jorge Mautner. Na beira da Lagoa Rodrigo de Freitas, contei ao professor da Pontifícia Universidade Católica do Rio de Janeiro (PUC-Rio) minha história, meus desejos e meus anseios. Eu sabia que não iria escrever o livro às custas do mestrado, mas achava que haveria de ter uma maneira de eu agregar os projetos e, ainda, estudar as questões que giram em torno das biografias. Expliquei a ele que, além de querer realizar meu desejo de "satisfazer a curiosidade dos leitores, e não demarcar seus limites" (MALCOLM, 1994, p. 17), precisava provar aos brasileiros que a música nordestina vai muito além dos baianos tão estudados, biografados e autobiografados. Fora isso, era preciso entender e explicar porquê esse artista 
de letras e mensagens tão pouco compreensíveis era tão adorado por seus fãs. Zé Ramalho, assim como outros paraibanos, pernambucanos, cearenses, maranhenses e potiguares, merecia ter sua importância registrada.

Júlio me olhou com interesse, convidou-me a assistir a suas aulas naquele segundo semestre de 2012 - o que me ajudaria a entender a linha de pesquisa para fazer a prova com mais segurança - e me levou à mesa em que sentaríamos para assistir à entrevista de Miguel Jost, também professor da PUCRio e estudioso da música, que antecedeu o show de Mautner. Ao ser perguntado sobre a gravação de sua composição "Maracatu atômico" por Chico Science e Nação Zumbi, os maiores representantes do movimento Manguebeat, de Pernambuco, o tropicalista fez um discurso sobre a importância de se olhar para esse Nordeste. Segurando meu braço, Júlio perguntou: "Ele estava ouvindo a nossa conversa?" E eu tive certeza, ali, que estava pronta para estudar meu biografado também na academia. Só me faltava colher alguma outra experiência autobiográfica, além da minha, para reforçar meu argumento e minha hipótese de que as referências diversificadas na música de Zé Ramalho é o que agrada aos fãs. Escolhi, para isso, três pessoas: o jornalista Mauro Ferreira, que cobre todo tipo de show e lançamento de disco no blog Notas Musicais e na coluna do jornal O Dia; o astrólogo Waldemar Falcão, que foi flautista da banda que acompanhou Zé Ramalho entre 1977 e 1982 e se tornou amigo do artista; e o músico pernambucano Geraldo Azevedo, amigo de Zé desde 1973 e parceiro em diversas composições. Pedi que eles me enviassem suas histórias, pois eu tinha certeza de que teria três experiências distintas e, ao mesmo tempo, complementares na minha busca pelo entendimento do sentimento de afeto que a canção do meu biografado é capaz de causar.

\section{Carta 1: Mauro Ferreira}

Rio de Janeiro, 10 de setembro de 2012.

Chris Fuscaldo! 
Em primeiro lugar, gostaria de agradecer por ter escolhido a mim, entre tantos jornalistas, para falar sobre minha experiência com Zé Ramalho e sua música. Sou um grande admirador seu e, como sabe, também um incentivador de sua trajetória. Estou muito orgulhoso de você estar conseguindo se dedicar à biografia deste artista tão importante para a música brasileira. Mal posso esperar para ter o seu livro em minhas mãos. Sou também um fã do músico paraibano e sempre lutei para inserir ele nos veículos onde trabalhei. Vou te contar essa história.

Eu sempre gostei do Zé Ramalho e de toda aquela geração nordestina. Coisa rara no meio da crítica musical carioca... Tem um preconceito meio velado contra eles. Não é explicitado, mas tem. A coisa do Nordeste, nem todos os editores gostam. Eu sempre defendi porque gostava musicalmente. Só que, quando entrei no mercado, em 1987, ainda estudante, peguei uma fase de produção do Zé que não considero o suprassumo da obra dele. Ele estava lançando o "Décimas de um cantador" e eu fiz uma crítica para o Jornal da Baixada Fluminense, sem repercussão. Ele é uma pessoa muito querida para mim hoje e acho que vice-versa, mas o meu primeiro problema com Zé aconteceu em 1992, quando ele lançou "Frevoador". Eu já estava no jornal O Globo, onde entrei no início de 1989, e acho que falei mal do disco na coluna Discolândia. Ele estava sem gravar um álbum de inéditas desde 1987, porque o que saiu em 1991 foi a compilação de sucessos nordestinos "Brasil Nordeste". Pessoalmente, Zé também estava em uma fase ruim. Eu não tinha maturidade para entender a relação entre a vida e a obra ainda e lembro que ele foi ao Sem Censura e acabou comigo. Eu não assisti ao programa, mas me disseram que ele me chamou de "viado", algo assim. Nunca tirei satisfação porque acho que, da mesma forma como eu tenho o direito de me expressar, ele também tem. E eu não fiquei ofendido, pois já estava acostumado com isso. Ele é que ficou ressabiado comigo durante um período. Isso é típico do Zé! Ele é uma pessoa muito passional, mas, ao mesmo tempo, muito amorosa. $E$, quando houve a redescoberta dele, a partir da novela $O$ Rei do Gado - que se não me engano teve a trilha sonora mais vendida da história da teledramaturgia - e seguida pelo projeto "O grande encontro", ele voltou a fazer discos 
mais vigorosos, como o "Cidades e lendas", em 1996, e o "Antologia acústica", em 1997. Eu elogiei esses trabalhos e, a partir daí, minha relação com ele ficou muito boa. Tanto que, já trabalhando para O Dia, em 2003, fui convidado a fazer textos para o libreto, release e videorelease do "Estação Brasil", o último da trilogia de álbuns duplos. Eu brinco que tenho uma placa em cima do meu vaso sanitário com a imagem de Zé Ramalho, porque consegui terminar as obras do meu banheiro com o pagamento efetuado pela BMG, na época. Fui convidado pela gravadora, mas com o aval do Zé. Fiz também o release do terceiro disco "O grande encontro", porque Zé, Elba e Geraldo sabiam da minha identificação com a música deles.

Meu primeiro contato com Zé Ramalho foi em 1978, quando ouvi "Avôhai" e "Vila do sossego" nas rádios. Quando ele lançou o segundo disco, eu era adolescente e fiquei muito atento. Eu nasci em 1965 e, aos 13, comecei a comprar discos com minha mesada. Sempre tive uma queda maior pelas cantoras, então, Elba me impactava mais do que todos os outros. Mas sempre gostei da voz cavernosa do Zé e da música dele, porque resgata uma coisa minha com o Nordeste. Eu amo o Nordeste! Não tenho raízes nordestinas, mas amo muita coisa que vem de lá. Eu sempre tive a mente e o coração abertos pra ouvir tudo que vem do Nordeste, coisa rara, repito, no meio da crítica musical do eixo Rio-São Paulo. As pessoas do nosso meio, Chris, tratam os nordestinos com um certo desdém. E eu vivia lutando para emplacar Elba e Zé n'O Globo, na época. Eu emplacava, mas definitivamente eles não eram os queridinhos. Nunca foram! Nunca me foi explicitado também que o problema era eles serem nordestinos, mas eu sentia, porque agradava muito aos editores a música cosmopolita, o pop de Londres, aquela coisa toda. Não era chique você falar de Elba Ramalho, de Ze Ramalho. Na segunda metade dos anos 1990, houve uma revalorização deles. "O grande encontro" foi muito marcante para todos. E a mídia paulista ainda parecia mais preconceituosa. Uma vez, chamaram Elba de "gralha do agreste". Não lembro se eu queria ser jornalista nos anos 1980, mas eu lia muitas matérias de música e achava aquilo muito forte, uma coisa violenta. Ela sofreu mais que eles, que eram compositores. Ela só tinha a voz. 
Além das críticas, eu também entrevistei eles. Lembro do lançamento do primeiro "O grande encontro". Todos estavam virados, tinham tocado na noite anterior, e Alceu não apareceu. Houve um clima de tensão, porque $O$ Globo me enviou junto a um fotógrafo e estava faltando um para a foto. A gravadora ligou para Alceu e me colocou para falar com ele ao telefone. Alceu ficou uma hora falando comigo e os três ficaram chateados. Sempre gostei muito de entrevistar o Zé, porque ele fala o que pensa, coisa rara nesse meio. Eu considero o período criativo do Zé entre 1978 e 1983. Mas a culpa do declínio de suas vendas não foi só dele. Em 1982, surge a Blitz e, em seguida, vem o Barão Vermelho e o mercado muda totalmente. A MPB se dissolve no pop quando os artistas são empurrados para escanteio. Para sobreviverem nesse cenário, Gal Costa teve que gravar Sullivan e Massadas e Simone apelou, gravando música de José Augusto. Maria Bethânia não se entregou, mas amargou vendas terríveis de seus álbuns na década de 1980. Zé até tentou fazer algo mais pop, mas a criatividade dele estava abalada pelas drogas. Amelinha foi outra vítima da popização de astros da MPB. Ela teve que aderir, gravou músicas como "Água e luz" num sotaque mais pop que, em um primeiro momento, até tocou no rádio, mas depois descaracterizou, porque ela se afastou um pouco do seu universo. Para voltar, é difícil. Ela era uma cantora de grandes possibilidades, mas acho que a mídia nunca deu muita bola pra ela. Lembro que eu falei sozinho, praticamente, do disco "Janelas do Brasil", que ela lançou no ano passado. Escrevi para $O$ Dia, que não tem a força que $O$ Globo tem. Agora, Alceu e Elba, contraditoriamente, viveram o maior sucesso deles a partir de 1982, ano em que Zée e Fagner começaram a morrer para o mercado: Alceu com o disco "Cavalo de pau" e Elba com "Alegria". Mas acho que os dois sempre tiveram uma atitude mais roqueira no palco e um repertório mais popular. Não foi à toa que fizeram shows na primeira edição do Rock in Rio, em 1985.

Eu queria te dizer também que achei que há vigor nos últimos discos do Zé, "Parceria dos viajantes" e "Sinais dos tempos". No primeiro, ele tenta abrir o leque de parcerias, mas nem tudo funciona. $O$ outro, acho que evoca bem aqueles tempos áureos dele. Atualmente, o problema não é com ele, mas com o público, que não está querendo mais ouvir músicas inéditas. Não falo de 
todo artista, mas de nomes como Ze e Fagner, que têm uma obra tão extensa que as pessoas querem ouvir só os clássicos. "Sinônimos", que Zé gravou com Chitãozinho \& Xororó em 2008, só estourou porque o mercado sertanejo é dominante no Brasil. Artistas como ele hoje sabem que, para sobreviver, não adianta fazer um show de músicas inéditas. Acho que é por isso que ele não incluiu no repertório músicas dos trabalhos mais recentes.

Eu gosto muito daquela geração! Gosto muito, muito! A obra do Zé é original. E acho o Zé uma figura querida, porque ele não é hipócrita nesse meio musical tão hipócrita. Todo mundo ama todo mundo pela frente e o Zé não tem isso: ele fala o que pensa. Não é uma figura queridíssima por causa disso. Acho que nós, jornalistas de música, também somos assim, né, Chris? Deve ser por isso que tanto você quanto eu nos identificamos muito com Zé Ramalho.

Espero que tenha te ajudado. Qualquer dúvida, me ligue ou escreva.

Beijos,

M.F.

\section{Carta 2: Waldemar Falcão}

Rio de Janeiro, 15 de setembro de 2012.

Cara Chris,

Para contar minha experiência com Zé Ramalho, eu precisaria de algumas tardes em sua companhia e na de seu gravador. Mas, como pediu que eu escrevesse, vou tentar ser sucinto e não fazer um liuro inteiro, afinal, a biografia em questão não é a minha, mas a do meu grande amigo Zé Ramalho. Bom, como você mesma me disse ao encomendar esse depoimento, é 
impossivel falar de Zé sem falar de todos nós que convivemos com ele. Uma história não pode ser contada só por uma pessoa, mas por todas que participaram da mesma. E, como cada ponto de vista é único e pessoal, espero que o meu contribua com sua pesquisa.

Não vou contar como comecei porque a história é longa. Vou direto ao momento em que tive contato com Zé Ramalho. Eu vi o show de Alceu no teatro Teresa Rachel, em que Zé tocava com aquelas botas pretas. Ele era o componente dark da banda e já tinha um papel todo especial. Depois, fui morar na Europa e, quando voltei, comecei a frequentar a casa da Lygia Itiberê, que era mulher do Chico Julien, baixista do Zé, e que abria as portas de seu apartamento no Jardim Botânico para a banda ensaiar para as gravações do primeiro disco do Zé Ramalho pela CBS. Chico era meu amigo e, lá, vi Zé tocando "Vila do sossego" pela primeira vez. Aquilo chamou minha atenção. Lembro que pensei: "Nossa, que letra louca essa que esse cara fez!" Criou-se uma afinidade logo. Hoje, somos compadres: sou padrinho da Linda junto a minha ex-mulher.

Minha familia era católica e eu comecei a frequentar um centro de umbanda aos 17 anos, quando minha avó foi diagnosticada com câncer no aparelho digestivo. 0 pai de santo não a curou, mas aliviou seu sofrimento. Com a astrologia, meu primeiro contato aconteceu na Inglaterra. Zé não frequentou nada disso, mas eu sempre percebi nele um cara muito intuitivo. Ele era autodidata. Nunca havia mergulhado nesses assuntos, mas conversava sobre tudo isso. Nossa amizade acabou sendo maior do que a dele com os outros músicos porque tínhamos esse interesse em comum. Lembro que ele autografou a capa do meu "A peleja do diabo com o dono do céu" assim: "Mazinho, para todos os outros que como nós gostamos de desafiar o mistério..." Lembro de ele falando sobre visões que teve de UFOS, sobre as leituras que fez de autores como Carlos Castañeda. Batíamos altos papos nos intervalos dos shows. A gente fumava maconha até não poder mais e ele me contou que, em "Avôhai", a expressão "manita matutina" referia-se a um cogumelo que cresce nas fezes da vaca.

A banda só tinha gente bacana: éramos dois flautistas, eu e Osvaldo Garcia; não tinha bateria, era o Serginho Boré que tocava percussão; Cátia de França ficava no acordeon e Pedro 
Osmar, na viola; Elba Ramalho, Lizzie Bravo e Mônica Schmidt faziam backing vocal; Paulinho Machado, o arranjador, tocava teclados; e Chico Julien era baixista. Zé fazia violão base. Depois do contrato assinado e o disco lançado, passamos a ensaiar em um estúdio de oito canais da CBS na Avenida Rio Branco, no Centro do Rio. Não participei do primeiro disco e não lembro se fui parar na banda a convite do Zé, do Paulinho Machado ou do Carlos Alberto Sion, o empresário de Zé na época. Sei que toquei com ele de 1977 até 1982. Foram cinco anos em que conheci o Brasil todo ao lado dele. Lembro do show emblemático que Zé fez com João do Vale no Projeto Pixinguinha, em 1979, e de Sion dizendo que tinha conseguido colocar "Vila do sossego" na Antena I, uma rádio superimportante. Lembro que Pedro Osmar também adorava essas conversas sobre coisas misteriosas, espirituais, e era muito engajado na política de esquerda, como todos nós da banda. Depois teve outra formação, com Fernando Moura no teclado e o Rui Motta na bateria.

Fui um dos primeiros que viu "Admirável gado novo" quando Zé completou a composição da música, porque parece que ele a começou ainda na Paraíba. Ele tinha cheirado sozinho, no hotel, e estava ligadão. No meio da madrugada, bateu na porta do quarto que eu dividia com Lizzie - eu pedi para ir para lá porque não aguentava o cheiro de cigarro do Osvaldo - e mostrou a canção. Ele apenas a tocou. Zé vai muito pelo simbólico e não pelo racional e 0 interessante é que ele gostou tanto que a música entrou no lançamento do show do primeiro disco, apesar de a termos gravado só no segundo. Neste sim eu participei, já no estúdio de oito canais da CBS. Eu tive que sair da banda porque, no meio de uma das temporadas, peguei hepatite e precisei de repouso. Chamei Raul Mascarenhas para me substituir e, depois, em 1982, fui estudar Engenharia de Gravação nos Estados Unidos. Eu estava interessado nas novas tecnologias e não queria mais acompanhar o declínio do Zé, pois eu já havia percebido que a barra estava pesada demais. Lembro de uma turnê dessas enormes que a gente vinha fazendo e, quando paramos em Araçatuba ou Araraquara, não me lembro, Zé falou para eu aparecer no quarto. Dei dois tequinhos e, no dia seguinte, acordei e tomei uma sauna, mas Zé e Chico viraram a noite e ficaram enlouquecidos na hora do show. Amelinha também cantava nesse show e, quando chegamos no 
ginásio, uns caras começaram a mexer com ela. Zé danou a xingar os caras e disse que não ia se apresentar. Eu estava montando meu equipamento nesse momento e não tinha visto o barraco. Sei que ele chamou todo mundo para voltar para o ônibus e eu demorei, porque tive que desmontar tudo. Depois, eu soube que o delegado da cidade mandou os policiais cercarem o ônibus e disse que, se 0 show não fosse apresentado, ele tiraria os homens dele e deixaria a plateia quebrar tudo. Zé acabou voltando e eu tive que remontar tudo de novo. Durante o show, a cada música que terminava, Zé ia lá no fundo do palco para xingar o contratante.

Bom, acho que tenho muito mais a te contar, mas prefiro que me diga o que quer saber.

Um beijo grande do amigo,

Mazinho

Carta 3: Geraldo Azevedo

Rio de Janeiro, 22 de setembro de 2012.

Olá, Christina! Tudo bem?

Desculpe a demora, eu estava viajando sem parar, mas consegui um tempinho para escrever essa carta para você. Vou tentar resumir a história, mas acho que vai ser difícil, pois são muitos anos de convivência. Eu conheci Zé em 1973, no set de filmagem do filme "A noite do espantalho", dirigido por Sérgio Ricardo. Lula Côrtes trabalhou na cenografia, eu fazia a direção musical e Alceu ganhou o papel do Espantalho. Zé ficou alguns dias hospedado lá na filmagem com a gente porque era amigo de Lula e Alceu. Ele já conhecia o "Quadrafônico" e tocava as músicas daquele nosso disco. Ele sempre me falava que um dia ia gravar "Mr. Mistério". A primeira 
canção própria que ele tocou para mim foi "Frágil" e, depois, "Vila do sossego". Lembro que achei uma coisa linda. Eu soube ali, também, que Zé, Lula e Robertinho de Recife produziram o álbum "No sub reino dos metazoários", de Marconi Notaro, um escritor e músico pernambucano que gravou uma música de Zé, "Made in PB". Nessa mesma época, conhecemos o assistente de fotografia de Tânia Quaresma, uma cineasta que fez uma filmagem pelo sertão com Zé Ramalho. Depois, ela chamou eu e Zé para fazermos parte da trilha sonora. A gente já tinha tanta química que decidimos ir para o estúdio e gravar simultaneamente à exibição do filme "Nordeste: cordel, repente e canção", eu com o violão e Zé com a viola. Aí, compus com Lula e Zé e gravei violão para algumas músicas de "Paêbirú" e, quando ele veio aqui para o Rio, a gente fez logo um show.

Zé ia muito na minha casa, em Laranjeiras. Também íamos muito na casa de Tânia, em Santa Teresa. Foi lá que começamos a compor "Táxi lunar". Eu tirei o trecho do refrão no qual $2 e ́$ colocou "Cuiabá" e que está em uma gravação ao vivo dele. Eu nunca tinha ido a Cuiabá, aquilo não fazia sentido! Mudei para "beira-mar". Zé colocou um pedaço de letra que só ele conseguia cantar, porque eu achava muito pesado. Hoje em dia, eu aceito mais essas coisas, mas na época eu contestava Zé, Alceu, todo mundo que colocasse letra que não era o que eu queria que soasse na minha canção. Quando gravei, tirei os versos de Zé e, quando ele gravou, foi com os versos.

Uma vez, lá nessa minha casa, estávamos lembrando umas coisas de Jacob do Bandolim, Pixinguinha, esses caras que são mitos pra gente, e começou a sair um choro. Zé começou um arpejo e a música foi surgindo. Ele parava e eu inventava uma frase. Quando vimos, tínhamos composto "Bicho de 7 cabeças". Primeiro, chamamos a composição de "16 cordas" porque somamos as seis cordas do meu violão com as 10 da viola dele. Fomos visitar Renato Rocha, meu parceiro, e ele gravou a nossa música. Passou algum tempo e ele me ligou dizendo que tinha colocado letra e o nome de "Bicho de 7 cabeças" no nosso choro. Quando mostrei para Zé Ramalho, ele ficou bravo. Não sei se foi o fato de ter mais um na parceria ou se ele não gostou da letra. Mas, ao mesmo tempo, quando gravou pela primeira vez, Zé usou o nome "Bicho de 7 cabeças", dando o crédito só do título para o Renato. No primeiro disco dele, fizemos ela 
instrumental, comigo no violão ovation, Zé na viola de dez, Arnaldo Brandão no violão de sete e Bezerra da Silva na percussão. Houve uma tensão porque, não sei se por causa da correria, ele acabou registrando a música como se fosse só dele. Depois, Zé mudou junto à editora, mas no crédito do primeiro disco dele não tem meu nome como coautor. Depois, em "O grande encontro", gravamos a música com letra, mas ele exigiu darmos o nome de "Bicho de 7 cabeças II".

Com ele, tenho também a composição "Pedras e moças". E temos ainda "Miragens", que comecei a fazer inspirado em um encontro com Cazuza, no qual ele me contou que, quando trabalhou na gravadora Som Liure, escreveu uma nota para a imprensa sobre um disco meu. Zé fez a letra e falou assim: "Quando eu botei as palauras, Geraldo, pensei muito na delicadeza de sua voz". Ah, e tem a nossa história particular com "O grande encontro", né? Você sabia que 0 projeto inicial era eu e ele num show chamado "Dueto"? Rodamos o Brasil inteiro, só eu e ele. Gravamos esse show, mas nunca lançamos porque, imediatamente, surgiu a ideia de fazermos o show a quatro. "Dueto" foi nos ajudando, mas a possibilidade de fazer algo com Alceu e Elba, artistas mais frequentes na mídia do que nós dois naquele momento, animou. Quando fizemos esse nosso show em Brasilia, Zé foi ao banheiro e ouviu um cara falar: "Quem perdeu esse show, perdeu a metade da vida!" Ele gostou muito e se inspirou na frase para escrever um trecho de "Miragens", claro, poetizando daquele jeito dele: "Em vez de emudecer, poderia cantar a mais linda canção sem lamento. Equem não escutar, perderia talvez a maior metade do tempo do sonho."

Bom, Christina, são muitas histórias, mas não sei se estou tomando o caminho certo para te ajudar no que você precisa. Aguardo sua ligação para me dizer se deseja algo mais.

Um abraço,

Geraldinho 


\section{A experiência com a morte}

Eu vivia dizendo que 13 era meu número da sorte, mas, se fosse escrever minha autobiografia, diria que o ano de 2013 foi controverso para mim. E minha expectativa era grande, afinal, antes de saber que fui aprovada para o mestrado da PUC-Rio, eu tinha mudado de emprego em outubro do ano anterior e virado editora de conteúdo de um setor novo da Artplan. Ao garantir minha vaga na universidade, combinei de ficar apenas seis meses na agência de publicidade, tempo necessário para estruturar a equipe e as funções e sair para me dedicar exclusivamente ao programa de Literatura, Cultura e Contemporaneidade, à biografia de Zé Ramalho e à organização do meu casamento. Depois de muitas ponderações, eu e Marco decidimos oficializar nossa união em 15 de novembro de 2013. Assim como Caio Fernando Abreu, eu nunca quis me casar: "Se você me amar e eu te amar, não precisamos da aprovação de ninguém para ficar juntos, como também não precisamos assinar nenhum papel ou aceitar qualquer espécie de jogo." (DIP, 2009, p. 167) Mas, relendo duas entrevistas, uma do ator Wagner Moura e outra de Rita Lee para a revista Rolling Stone, comecei a mudar de opinião. A musa do rock soltou uma declaração engraçada, mas delicada ao mesmo tempo:

Não nasci para casar e lavar cuecas. Queria a mesma liberdade dos moleques que brincavam na rua com carrinho de rolimã. Quando entrei para a música, percebi que a "tchurma" dos culhões reinava absoluta, ainda mais no rock. "Oba", dizia eu, "é aqui mesmo que vou soltar a franga e, literalmente, encher o saco deles". Depois que provei a mim mesma que era capaz de conseguir as mesmas vitórias, sosseguei um pouco o facho. Principalmente depois que Roberto entrou na minha vida feito um Lancelot. Minha Guinevere pôde então exercer a função de namorada, amante e mãe. No palco, sou mais macho do que fora dele, não posso negar que minhas influências como figura de frente foram Jagger, Bowie, Tyler, Rod Stewart. ${ }^{28}$

28 PRETO, Marcus. "Não nasci para casar e lavar cuecas". Rolling Stone, edição 15, ano 2, no 15, p.86, Dez. 2007. 
Já Wagner falou uma das frases mais lindas e contemporâneas que já li sobre o matrimônio: "O casamento é uma instituição moderníssima. Hoje, nada mais obriga duas pessoas a estarem juntas, a não ser o amor." ${ }^{29}$ Fora isso, lembrei que, mesmo rebelde, Zé Ramalho se casou com Ísis na Igreja. Convencida, combinei com Marco, então, de fazermos uma festa cujo tema seria o Nordeste para comemorar não só o início da nossa história como também os encontros que tivemos nas capitais lá de cima. Com muito trabalho, estudo e pesquisa pela frente, o ano começou animado, mas minha alegria durou pouco. O motivo foram as diversas experiências que vivi com a morte.

Em 15 de fevereiro, um dos meus melhores amigos de São Paulo morreu em um acidente que me pareceu absurdo: trabalhando em prol do meio ambiente, durante um temporal, ele foi atingido por uma árvore no sítio que acabara de comprar e estava reflorestando. End era um grande incentivador do meu projeto e já tinha me apresentado a todas as pessoas de Sampa que ele acreditava que poderiam me ajudar na busca por uma editora. Apesar de advogado ambiental, o sócio e melhor amigo de Flávio, outro grande amigo que, assim como ele, era um apaixonado por música e segue me incentivando até os dias atuais, End tinha contatos interessantes. Conheci os dois naquela viagem a Cuba, em 2006, e só nos desgrudávamos quando eu tinha que pegar o avião de volta para o Rio ou eles, para São Paulo. Não consegui resolver muita coisa, mas pelo menos conversei com gente ligada a editoras, especialistas em submeter projetos a editais e outras pessoas interessantes. Com a morte de End, meu ano começou muito mal. Menos de um mês depois, no dia 26, foi a mãe de Rodrigo, meu amigo fotógrafo, que veio a falecer devido a um câncer. $E$ em 8 de março, Zé Ramalho sofreu uma ameaça de morte.

Para minha sorte, quando essa notícia chegou até mim, as coisas já estavam mais ou menos resolvidas. Mas eu tomei um baita susto quando recebi a ligação de um editor que estava tentando me seduzir desde o ano anterior com uma proposta um pouco indecente: a de assinar o contrato com a editora que ele tinha acabado de fundar e ainda não havia mostrado ter potencial de distribuição dos produtos que ele gostaria de lançar. Encontramo-nos duas vezes em 2012 e

29 CRUZ, Ricardo Franca. "Coragem sob fogo". Rolling Stone, edição 49, ano 4, no 49, p.86, Out. 2010. 
questionei em ambos os momentos a garantia que ele me daria de que a parceria seria benéfica para mim e para meu livro, já que, financeiramente, eu não teria vantagem alguma, afinal, ele não se propunha a dispor de nenhum tipo de adiantamento. Como a resposta nunca vinha com firmeza, eu dizia que preferia, então, esperar o livro ficar pronto para começar a negociar a melhor estratégia de lançamento. Outras editoras pequenas como essa já haviam me procurado e o problema que elas me apresentavam era sempre o mesmo: não havia garantia de que o livro chegaria às livrarias do Nordeste, onde Zé Ramalho tem uma quantidade enorme de fãs. Naquele dia fatídico, acho que, ao me ligar, o editor estava tentando se manter próximo: "Oi, Chris, tudo bem? Como é que você está? Tudo bem mesmo? Pelo seu tom de voz, você não está sabendo do que aconteceu. Seu biografado, Zé Ramalho... Parece que ele está muito mal. Li ainda agora em um site de notícias que ele foi internado hoje. Claro! Faça isso! Desculpe te dar a notícia assim. Eu jurava que você, a biógrafa dele, já sabia. Boa sorte e, qualquer coisa, me ligue." Meu sangue ferveu e minhas pernas tremeram. Eu tinha saído da minha sala da Artplan e me dirigido para o banheiro para falar ao telefone com mais privacidade, mas eu não esperava por aquela notícia. Pensei logo que 2013 era um ano que nem devia ter começado, mas, mantendo-me firme, avisei ao "amigo" que eu não soube porque estava trabalhando focada, mas que iria apurar, e desliguei o telefone. Telefonei para Marco e pedi para ele me ajudar, já que o 3G do meu celular não me permitiu acessar nenhum site de notícias. Do seu trabalho, meu noivo colocou o nome de Zé Ramalho no Google e achou uma matéria noticiando que ele havia sido submetido a uma cirurgia. Marco me tranquilizou naquele momento de nervosismo em que nem Otto nem Roberta me atendiam. No dia seguinte, soube que Zé havia colocado cinco pontes de safena.

O cantor paraibano José Ramalho, de 63 anos, deu entrada no Hospital Samaritano, em Botafogo, na Zona Sul do Rio, com quadro de angina instável, na última segunda-feira, dia 4. Ele foi submetido a um cateterismo, que identificou lesões, indicando necessidade de tratamento cirúrgico. Segundo o cardiologista Maurício Vaisman, nesta quinta-feira, dia 7, o quadro clínico de José Ramalho era estável. Ainda de acordo com boletim médico, Ramalho encontrava-se internado na Unidade Coronariana em pós-operatório, respirando sem o auxílio de aparelhos. Nesta terça-feira, dia 5, durante a manhã, o artista passou por uma 
revascularização miocárdica, com a equipe do cirurgião cardiovascular Valdo Carreira. Segundo boletim médico, o quadro clínico inspirava cuidados e ainda não havia previsão de alta hospitalar. ${ }^{30}$

No dia 31 de maio, levei Marco pela primeira vez a um show de Zé Ramalho, em Curitiba, cidade onde meu noivo foi criado. Zé parecia leve após o susto e os fãs pareciam mais eufóricos do que eu estava acostumada a ver. $\mathrm{Na}$ semana seguinte, por sorte, era um sábado e eu não estava conectada como de costume, o que me fez me livrar de mais um susto. No dia 8 de junho, voltando de um almoço na casa dos meus pais, em Niterói, acessei a internet pelo celular e vi uma série de publicações nas páginas de amigos meus no Facebook, dizendo que é uma vergonha para a categoria saber que ainda há jornalistas cometendo o erro de noticiar a morte de uma pessoa que não morreu. Tratava-se de Zé

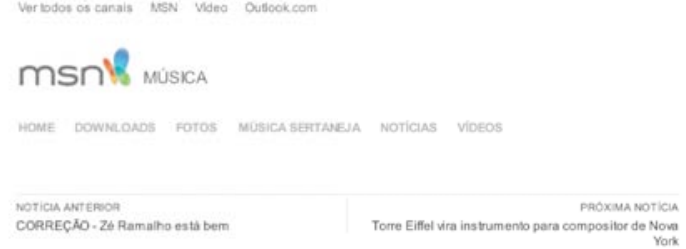

CORREÇÃO - Zé Ramalho está bem
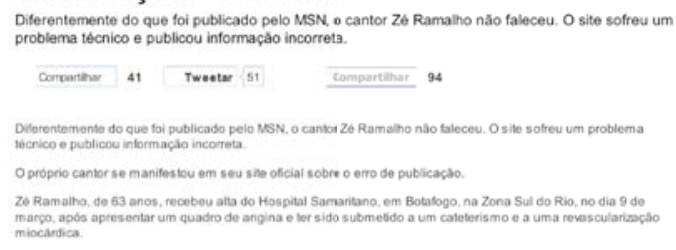

Ramalho o vivo em questão. Só que, desta vez, dei uma risada, não porque achei a situação divertida, mas porque tenho mania de rir de situações esdrúxulas - mania esta que me fez ter que sair da sala de aula várias vezes, na época da escola. Li para Marco a errata do MSN, site onde teria começado o boato através da matéria de título "Morre cantor Zé Ramalho, aos 63 anos". Sob o título "CORREÇÃO - Zé Ramalho está bem”, o site publicou:

Diferentemente do que foi publicado pelo MSN, o cantor Zé Ramalho não faleceu. O site sofreu um problema técnico e publicou informação incorreta. O próprio cantor se manifestou em seu site oficial sobre o erro de publicação. Zé Ramalho, de 63 anos, recebeu alta do Hospital Samaritano, em Botafogo, na Zona Sul do

30 Zé Ramalho é internado no Rio e tem quadro estável, diz boletim médico. Disponível em $<$ http://g1.globo.com/rio-de-janeiro/noticia/2013/03/ze-ramalho-e-internado-no-rio-e-tem-quadroestavel-diz-boletim-medico.html>. Acesso em: 08 mar. 2013. 
Rio, no dia 9 de março, após apresentar um quadro de angina e ter sido submetido a um cateterismo e a uma revascularização miocárdica. ${ }^{31}$

Se bem conheço a rotina de uma redação, provavelmente algum repórter publicou sem querer o obituário que havia sido feito em março, quando Zé Ramalho foi internado. É comum os jornalistas prepararem a matéria com o resumo da biografia de pessoas de idade ou que sofrem algum tipo de doença. Eu mesma fiz obituários de diversos artistas que não tinham morrido ainda, quando trabalhava na Infoglobo. $\mathrm{E}$ achei muito engraçado quando descobri que o profissional que escreveu o obituário de Oscar Niemeyer para o jornal inglês The Guardian morreu aos 69 anos em 2008, quatro anos antes do arquiteto, que chegou aos 104 anos e faleceu em $2012^{32}$. Olha aí eu rindo de coisas esdrúxulas de novo... Só que é óbvio que não se pode publicar o texto sem a confirmação do falecimento. Para Zé Ramalho, a correção chegou tarde demais. Com show marcado naquele mesmo dia, além de ter que desmentir o boato para garantir aos contratantes que ele subiria ao palco de llhéus, na Bahia, o artista ainda tinha que avisar a seus fãs o absurdo que estava acontecendo. E ele fez isso através das redes sociais:

\begin{abstract}
Ninguém faz matéria de jornal para dizer que você está ótimo, que está super bem de saúde após a cirurgia, que está cantando melhor do que nunca, que bateu todos os recordes e expectativas dos médicos. Mas são capazes de inventar e espalhar, criminosamente, uma matéria mentirosa, alegando que você está no hospital ou que se foi. Quanta maldade escondida sob o anonimato da internet! Semelhante ao boato criado contra o bolsa família, divulgaram, hoje, um boato sobre minha saúde. Bem, se nem a PF consegue encontrar os cyber-bandidos, o que fazer? Vamos hoje ao show em Ilhéus, no Centro de Convenções Luís Eduardo Magalhães, e verão Zé Ramalho e Banda Z cantando e tocando pra vocês! Não se deixem enganar, pois "os olhares do mal brilham mais que os do bem". Zé Ramalho. ${ }^{33}$
\end{abstract}

Joguei o nome de Zé Ramalho no Google e encontrei uma série de matérias, algumas dizendo que meu biografado havia morrido e outras

31 CORREÇÃO - Zé Ramalho está bem. Indisponível. Acesso em: 08 jun. 2013.

32 GIRON, Luís Antônio. A morte antecipada de Niemeyer. Disponível em $<$ http://revistaepoca.globo.com/cultura/luis-antonio-giron/noticia/2012/12/morte-antecipada-deniemeyer.html>. Acesso em: 10 jun. 2013.

33 Texto publicado na página de Zé Ramalho no Twitter. Acesso em: 08 jun. 2013. 
desmentindo o boato. Sensível, Marco comentou que eu devia copiar todas as páginas referentes ao assunto, pois a questão da morte temperaria a minha biografia. O mais engraçado foi que, mesmo os sites que corrigiram a informação, ficaram com a notícia da morte em seus endereços, afinal, uma vez publicada na rede, a notícia pode ser editada, mas seu link, não. E eu sabia disso desde os tempos do site de O Globo. Grande sacada a do meu noivo! O processo de apagamento do erro, ou seja, da retirada da matéria da rede não é fácil, porém é possível. Na tarde em que ocorreu o episódio, capturei os links e as imagens, que acabaram saindo do ar depois de alguns meses.

Janet Malcolm tem uma frase que me intriga e que veio à mente quando ocorreu esse episódio: "A vida, é claro, jamais captura toda a atenção de alguém. A morte é sempre interessante e nos atrai" (MALCOLM, 1994, p.68). No ano seguinte, novamente voltei a pensar sobre isso quando ouvi o escritor e biógrafo Ruy Castro, responsável pela produção de livros sobre a vida de Nelson Rodrigues ("O anjo pornográfico"), Mané Garrincha ("Estrela Solitária”) e Carmen Miranda ("Carmen"), dar um depoimento parecido em 02 de agosto de 2014, durante uma palestra na Flip 2014 (Feira Literária de Paraty): "Biografado vivo não é confiável". Ao contrário do professor Teixeira Coelho, que em 1994 publicou um livro em que narrava as angústias de um escritor à espera da morte de Oscar Niemeyer para escrever a biografia "definitiva" do arquiteto, sempre desejei escrever sobre os vivos. Eu me sentiria mais honesta se desse voz aos personagens da minha história. Fora que ficaria mais segura com a ajuda deles do que se tivesse que interpretar sozinha documentos e registros históricos de épocas que não vivi. Ao mesmo tempo, desde que comecei a buscar uma editora, sabia que, para elas, Zé Ramalho seria um biografado mais instigante se não estivesse mais entre nós. Assim como Raul Seixas, Cazuza, Renato Russo e Tim Maia se tornaram ícones nacionais muito mais potentes depois de mortos, Zé também é um mito em potencial nesse mundo em que o reconhecimento pode vir em vida, mas é muito maior depois da morte. A mesma coisa que Manuel Bandeira falou sobre Mário de Andrade, eu diria de Zé: "Para um homem como Mário de Andrade não pode haver morte 'que acaba tudo'." (ANDRADE, 2001, p. 14) Mas eu não queria isso. Além da autorização, ele me deu permissão 
para que eu descobrisse as nuances nunca contadas de sua história e resgatasse memórias que nem ele tem mais. E eu queria fazer isso com ele vivo, lendo, relembrando e se emocionando com sua própria trajetória.

No ano seguinte, em 03 de março de 2014, Zé Ramalho diria, em entrevista ao site do Estadão, que não guardava mágoas: "Isso é um fenômeno dos tempos em que vivemos. (...) Cito aqui o grande poeta Zé Limeira: 'Ano passado eu morri, mas esse ano eu não morro.' Hoje estou completamente recuperado, gozando de saúde plena." ${ }^{4}$ Depois do susto, o dever de Zé era o mesmo de Graciliano: a vida. "A experiência do retorno à vida serve para desmistificar os seus atrativos e a sua graça, para repudiar os prazeres que oferta a quem perde todas as esperanças de continuar entre os vivos." (SANTIAGO, 2013, p. 67). O meu era tentar agilizar a minha pesquisa.

34 NOBILE, Lucas. A volta do que não foi. Disponível em < http://cultura.estadao.com.br/noticias/musica,a-volta-do-que-nao-foi,1136977> Acesso em: 03 mar. 2014. 


\section{Um biografado cada vez mais distante de sua biógrafa}

Em 3 de agosto de 2013, Zé fez seu primeiro show no Rio depois de toda a confusão. No palco, agradeceu ao médico que seguiu o acompanhando, fez-me chorar mais uma vez durante "Avôhai" e não me recebeu em seu camarim. Aliás, pela primeira vez, os convites separados para mim por sua produção me colocaram na parte de trás da plateia, coisa que não tinha acontecido ainda desde que me aproximei dele. Vi outros jornalistas na frente e senti algo estranho. Não era inveja ou aquela sensação de abandono que nós sentimos em algum momento depois que saímos da redação para trabalhar como autônomos. Eu já tinha me acostumado a não ser credenciada para alguns dos shows e eventos que queria cobrir para o GarotaFM ou a conseguir convites longe do palco. Não me fazia mal, principalmente porque eu sabia que, naquele primeiro ano do mestrado, vivia um outro momento da minha carreira... Era quase um período sabático, apesar de ainda estar na ativa com o meu blog e com os diversos serviços que seguia prestando como freelancer para músicos e gravadoras. No caso do Zé, era diferente. Teoricamente, eu era a biógrafa dele e tinha alguma proximidade, mesmo que fizesse pouco mais de um ano do nosso último contato. Comecei a questionar lá mesmo, usando Marco como interlocutor: "Será que ele desistiu de acreditar que vou escrever a biografia?"; "Será que aceitou que outro jornalista produzisse uma também?". E fui para casa com a pulga atrás da orelha. Publiquei, no GarotaFM, uma matéria que misturava sentimentos, na qual abordei o espetáculo, o retorno de Zé aos palcos cariocas e a dificuldade que eu vinha enfrentando na busca por uma editora. Nela, lembrei daquele editor que disse que Zé não venderia dois livros:

Se tinham ali 5 mil pessoas e pelo menos $1 \%$ desse público comprasse o livro com a história do ídolo, eu já teria 50 leitores. E, se 1\% daquela plateia de 3.400 do Master Hall, em Curitiba, com a qual me envolvi em junho, fizesse a mesma coisa, eu teria mais 34 compradores. Com $1 \%$ dos fãs que cantavam junto com Zé 
no Marco Zero, no Carnaval de Recife de 2010, no qual eu estava presente, acho que pelo menos 500 livros seriam vendidos. ${ }^{35}$

Para completar, encontrei no show o jornalista e diretor do selo Discobertas, Marcelo Fróes, que tinha acabado de montar uma editora de livros. Ele comentou que Zé Ramalho estava desconfiado de que meu projeto tinha sido abandonado. Não aguentei aquela sensação e resolvi escrever para Zé.

\author{
De: Christina Fuscaldo \\ Para: Zé Ramalho; Roberta Ramalho \\ Enviadas: Segunda-feira, 19 de Agosto de 2013 15:09 \\ Assunto: Biografia
}

\title{
Oi, Zé, tudo bem?
}

Fui a dois shows seus este ano e fiquei feliz de vê-lo novo em folha no palco. Mais ainda por ver uma plateia tão empolgada, tanto em Curitiba quanto no Vivo Rio.

Falei com o Fróes esses dias e ele comentou que parecia que você estava achando que o liuro não estava andando... Mas o liuro está andando, sim. Só que, diante da questão da falta de uma editora, estou trabalhando no meu tempo, por estar nisso sozinha (sem apoio financeiro ou de equipe). Não consegui falar com você e com Roberta no início do ano, mas ingressei no mestrado da PUC (no programa Literatura, Cultura e Contemporaneidade do curso de Letras) e levei seu nome para estudar lá. Isso já me fez escrever 45 páginas e vai fazer muito mais até o ano que vem. Fiz novas entrevistas este ano e estou me dedicando para que, até o fim de 2014 ou o início de 2015, tenha um liuro que não sofra nenhum dos problemas que as biografias andam sofrendo devido àquela Lei que Roberto Carlos usou para processar tanto a editora quanto o autor da biografia dele. As editoras não estão pegando projetos de biografia desde 2009 por causa disso. Editoras pequenas vivem me procurando, mas não me interessa le acho que também não interessa 
a você) trabalhar sem adiantamento para uma editora que vai deter os direitos autorais e o título em seu catálogo para sempre e não distribuí-lo (precisamos que o liuro chegue no Nordeste). A questão financeira faz diferença nesse processo. Pago sozinha as minhas contas e não tenho uma renda a não ser a do trabalho, o que me deixa com muito pouco tempo para meus projetos paralelos. Por isso tomei a decisão de levar a biografia para o mestrado. Pelo menos lá eu tenho a obrigação de escrever (e não só pesquisar, como vinha fazendo desde 2009). Esse momento está sendo ótimo! Por outro lado, não posso impedir outra pessoa de querer fazer também uma versão do livro da sua vida.

$$
\begin{aligned}
& \text { Uma pergunta... Você acha a editora do Fróes uma boa? } \\
& \text { Beijos, } \\
& \text { Chris }
\end{aligned}
$$

Com este e-mail, eu aproveitava para sondar ele sobre a nova empreitada do Fróes. Se ele aprovasse a ideia, eu poderia me unir ao jornalista. Só que Zé Ramalho nunca o respondeu. E, no dia 23 de agosto, finalmente o encontrei. Quase não conseguir ser credenciada pela Approach, a assessoria de imprensa do Rock in Rio, para a entrevista coletiva que Zé e a banda de heavy metal Sepultura dariam. De uma forma desrespeitosa, as

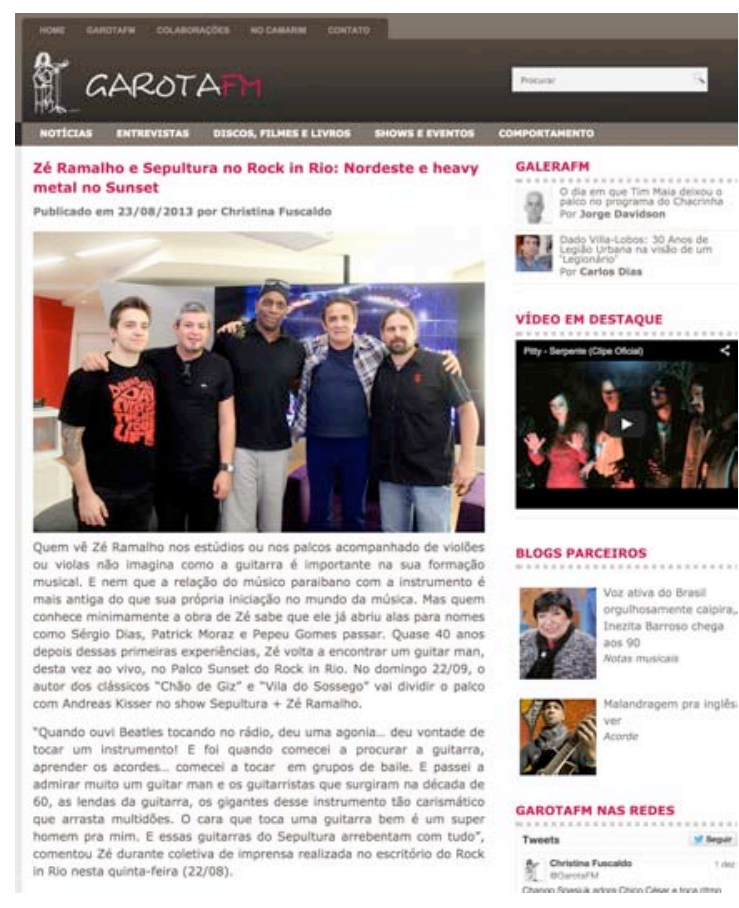
assessoras ignoravam meus pedidos por telefone e por e-mail mesmo eu explicando que, além do GarotaFM, eu estava trabalhando na biografia de Zé. 
Eu evitei tomar medidas mais drásticas, mas não teve jeito: em cima da hora, consegui fazer contato com o querido Zé Ricardo, o diretor do Palco Sunset, onde as atracões se apresentariam no dia 22 de setembro, e ele liberou minha participação. Ufa! Eu falei a ele que já estava acostumada com as negativas, mas nunca havia passado por uma situação em que, mesmo eu insistindo e argumentando, teria tanta dificuldade. Eu estava por dentro do tema, afinal, já tinha entrevistado o guitarrista Andreas Kisser sobre a gravação da pesada que as duas atrações fizeram de "A dança das borboletas", de Zé, para a trilha sonora do filme "Lisbela e o prisioneiro". Depois de passar por isso, consegui armar meu tripé com a câmera, ligar meu gravador e obter boas declarações de Zé ${ }^{36}$, que não me poupou das piadas durante a entrevista: "Chris Fuscaldo vai se casar, gente!" Fiquei vermelha, mas arquei com as consequências de tê-lo avisado disso através do convite que deixei em sua portaria. Eu sabia que Zé não compareceria no meu casamento, mas eu me sentia na obrigação de convidá-lo, afinal, de alguma forma ele fazia parte da minha história. Não sei se o ato reforçou a ideia de que eu não estava trabalhando pela biografia, mas foi o que pareceu, afinal, aquele foi o ano em que meu biografado se colocou mais distante de mim. Tentei aproveitar a simpatia na coletiva para uma reaproximação. "A esperança foi a única coisa que ficou dentro da caixa que Júpiter ofereceu a Pandora." (RAMOS, 2011, p. 45).

\author{
De: Christina Fuscaldo \\ Para: Zé Ramalho; Roberta Zé Ramalho \\ Enviadas: Sábado, 24 de Agosto de 2013 16:54 \\ Assunto: Re: Biografia
}

\title{
Oi, Zé e Roberta!
}

Você quase me matou de vergonha na coletiva, hein? Dizer pra todo mundo que eu vou me casar? Como vou manter minha "fama de mau", agora? Quem vai dar crédito a uma jornalista que sempre se fez de alternativa e, de repente, resolve se casar na lgreja?

36 FUSCALDO, Christina. Zé Ramalho e Sepultura no Rock in Rio: Nordeste e heavy metal no Sunset. Disponível em <http://garotafm.com.br/2013/08/23/ze-ramalho-e-sepultura-no-rock-inrio-nordeste-e-heavy-metal-se-encontram-no-sunset/> Acesso em: 24 ago. 2013. 
Dando novos passos, esta semana tenho um encontro na Bienal com um editor. Não vou criar expectativas, porque sei que ele vai me pedir o livro pronto para avaliar e isso só terei no ano que vem. Mas pelo menos foi ele quem me convidou para a conversa. Parece que a porta está aberta.

Escrevo mesmo para pedir sua parceria nesse projeto. Uma coisa que é extremamente importante para um biógrafo é participar um pouco mais das rodas frequentadas pelo biografado. Não quero invadir sua praia nem entrar na sua casa ou me misturar à familia. Mas estar no ensaio que fará com o Sepultura, nos bastidores de alguns shows, nas entrevistas que dá a alguns veículos, em ensaios com sua banda ou gravações de álbuns, isso tudo é muito importante para que, além de conversar e tirar dúvidas que ficam sobre sua história (vida e obra) com você e seus parceiros, possa também entender mais ainda o seu comportamento.

Outra coisa muito importante é ter seu aval para certas entrevistas. Muita gente tem medo de falar, acha que vou escrever algo que possa te magoar ou magoar alguém. Tenho dito que você vai acompanhar a revisão e que posso até enviar trechos do liuro também a essas pessoas, mas nunca sei se o problema é a agenda dos antistas mesmo ou a vontade dos assessores e empresários. Elba Ramalho, por exemplo, já disse que fala comigo, mas o empresário dela nunca marca um dia e um horário. Acho essencial ter as histórias dela com você e tenho certeza de que, com uma carta sua ou uma simples ligação ou e-mail, rapidinho ela arranja esse tempinho. Foi assim que você fez com a tia Zélia, lembra? E foi ótimo ter conseguido aquela entrevista.

Enfim, como te disse, estou sozinha nessa, investindo a pouca grana que ganho como jornalista nas viagens, ligações, idas e vindas. Seria ótimo se eu pudesse economizar um pouco do tempo que perco tendo que ligar ou escrever toda semana para as mesmas pessoas tentando em vão agilizar o processo. Queria ver se você ou Roberta conseguem me dar uma força, sendo com uma carta ou fazendo esses contatos quando eu precisar.

Bjs,

Chris 
A emenda saiu pior do que o soneto. A resposta veio através de Roberta e eu a achei bem desaforada. Ela dizia que Zé não faria nada do que eu tinha pedido. No máximo, ele me daria novas entrevistas por e-mail, porque estava cansado das presenciais, coisa que fazia há 40 anos. Participação no dia a dia profissional era "too much" e ele nunca falaria com nenhum dos parceiros para me ajudar. Entre uma frase e outra, ela sugeria que o Henri Koliver tinha sido mais eficiente - visto que ele tinha corrido atrás por conta própria - ao mesmo tempo em que confessava que esse escritor tinha tido suas facilidades, afinal, para ele Zé deu várias entrevistas. Roberta ainda entregou o ouro ao me contar que o Fróes também ia fazer um livro e que Zé já havia avisado que não daria entrevista alguma a ele, o que depois concluí que foi um mal entendido porque o projeto não foi tocado pelo jornalista. Por fim, ela dizia que o livro era meu e não do Zé e pedia para eu não me magoar. Reli meu e-mail para verificar se eu tinha sido tão inconveniente quanto ela me fez sentir que havia parecido. Lembrei de Mário: "Esta história de discussão por carta dá ocasião à mal-entendidos engraçados. Atribues-me intenções que não tive e te atribuí umas que não tiveste... Não tem importância. Continuemos que isto é bom." (ANDRADE, 2001, p. 52) Mas a questão não era eu me magoar ou não! Primeiro, porque, eu sempre soube que "o que é preciso é o sujeito estar preparado para receber todos os choques da adversidade." (RAMOS, 2011, p. 45) A questão era a minha expectativa de fazer uma biografia de qualidade e não uma que deixasse "aquelas sensações vagas de insatisfação" (MALCOLM, 1994, p. 24) que Janet sentiu ao ler o livro de Anne Stevenson sobre Sylvia Plath.

Estava difícil entrevistar muitas das fontes necessárias e eu acreditava que a maioria delas desconfiava de mim pelo fato de eu não estar trabalhando em uma redação ou por não ter uma espécie de carta de recomendação de Zé Ramalho. Eu só descobri no ano seguinte que o problema não era comigo... Ou não só comigo. Como Zé não é um homem de fazer muitos favores, alguns de seus parceiros também não fazem questão de retribuir. Poderia ser dele a frase de Graciliano reproduzida (ou terá sido inventada?) por Silviano: "Lá fora, reclamavam do meu orgulho de cabra nordestino. Chamavam-me de altivo, 
pouco acessível à solidariedade, de frio diante do calor humano dos verdadeiros companheiros." (SANTIAGO, 2013, p. 62) Fiquei refletindo sobre a relação de Zé com outros artistas. "La escritura responde a esas señales construyendo un espacio de resonancias, un espacio imaginario en el que el sujeto, avanzando en lo desconocido de sí mismo, descubre una perspectiva secreta para pensar la forma de sus vivencias, su forma de estar en el mundo con otros." (GIORDANO, 2006, p. 49) Cheguei a imaginar que o fato de eu mexer em feridas abertas ou mesmo nas fechadas - podia estar Ihe causando um mau-estar. Fora tudo isso, eu nunca pretendi competir com Henri Koliver ou com Marcelo Fróes e, da maneira como a esposa de Zé falou sobre os dois, senti que fui colocada num ringue de luta. Depois desse e-mail, mais uma vez pensei em desistir de tudo e executar aquele plano B que tracei quando decidi entrar para o mestrado: graduar-me e mudar de área profissional.

Em uma conversa por telefone com Ceci Alves, minha melhor amiga da Bahia, uma jornalista e cineasta com dois curtas-metragens premiados no currículo e minha parceira em um roteiro de um longa-metragem sobre a história de Zé Ramalho, que começamos a escrever no início de 2013, inspiradas em minha saga pela publicação da biografia do artista, decidi não deixar aquilo passar em branco. Ceci diz que devo ter sido cangaceira em outra encarnação devido minha paixão pelo movimento, minha garra e meu poder de argumentação em uma briga. Ela sugeriu que eu dissesse a Roberta que não sou "marreteira", gíria baiana para definir pessoa que não é séria, e que eu não queria lutar, mas fazer o meu trabalho. Pensei bastante e reconheci que Zé estava agindo como o meu pai (e como o de Keith Richards) quando brigávamos: "Não falar comigo, nem reconhecer que eu estava ali era a maneira dele de me disciplinar." (RICHARDS, 2010, p. 82) Não encarnei Maria Bonita nem Lampião, mas escrevi para Roberta com muita educação, quase dois meses depois de pensar muito e menos de um mês antes do meu casamento, que foi a última coisa que eu faria no Brasil naquele ano. 
De: Christina Fuscaldo

Para: Roberta Ramalho

Enviadas: Segunda-feira, 21 de Outubro de 2013 5:56

Assunto: Re: Biografia

\section{Oi, Roberta, tudo bem?}

Estou para responder seu e-mail há tempos, mas queria pensar um pouco antes de escrever e acabei me enrolando com os projetos do mestrado e do casamento.

Primeiro, eu gostaria de pedir para que não se preocupem porque nenhuma dessas mensagens me deixa triste ou me magoa. Quando decidi que queria mergulhar nesse projeto, eu sabia que não ia ser fácil. Como todo jornalista faz quando precisa de mais informação para uma matéria, eu preciso tentar, certo? Ainda mais precisando de mais informações para um liuro... Aprendi no mercado que o máximo que pode acontecer é eu ouvir um "não", mas que é importante sempre tentar. Talvez eu tenha ficado abusada demais depois de 14 anos tentando... 0 que é importante para mim é saber se estou sendo inconveniente com vocês. Lendo seu e-mail, senti que talvez eu esteja precisando medir meus pedidos. Pareceu que vocês ficaram muito incomodados com minhas mensagens e isso é algo que não quero de jeito nenhum. Se for o caso, peço mil desculpas e peço também para que você me situe melhor dos limites que posso estar ultrapassando (sem se preocupar se vai me magoar).

Como disse, eu sabia que não ia ser fácil. Uma questão que me surpreendeu nessa trajetória foi essa que acabou gerando a discussão sobre as biografias que está rolando agora. Vocês devem estar acompanhando também, né? Se eu tivesse pego a autorização do Zé um ano antes, estaria com o contrato assinado e, provavelmente, com o liuro pronto. Sem dúvida, esse imbróglio todo tem me atrapalhado muito, principalmente na marcação das entrevistas. Com certeza o Henri Koliver não passou por isso 15 anos atrás... Mas isso não vai me impedir de 
continuar. Se eu tiver que levar os mais de dez anos que o Paulo César de Araújo levou para escrever a biografia do Rei, vou me manter firme na proposta. Não comecei isso à toa...

Por falar no Henri, eu já tinha o liuro dele e comprei a reedição. Mas é um livro de transcrição de entrevistas, né? Quem conta a história ali é o próprio Zé... Parece que não teve uma edição. Tem muito material para usar como fonte de pesquisa, mas gostaria de saber se vocês assinam embaixo de tudo o que está escrito ali. Não conheço o autor para ter certeza de que posso confiar no conteúdo.

Sobre o Fróes, perguntei sobre a editora (a Sonora) porque ele andou me sondando para conversarmos. Como sei que vocês conhecem os projetos mercadológicos dele mais a fundo do que eu (eu o conheço methor como jornalista), queria saber se acham a editora bacana. Mas, se ele também está escrevendo um liuro, acho que agora a coisa ficou meio confusa. Mas não faz diferença para mim o que ele faz ou quer fazer, porque eu realmente preciso do ano de 2014 para chegar ao ponto para mostrar o livro para uma editora. Se o dele sair antes, mudarei o formato do meu e pronto. Isso é uma coisa que aprendi ser possivel com as conversas no mestrado e com os mil editores com os quais estou em contato.

Roberta, se o Zé não quer me dar nada além de entrevistas por e-mail, tudo bem. Esse é um formato possível. Torna o processo mais difícil, mas não impossível. Fiz uma discobiografia da Legião Urbana sem falar com o Renato Russo, então, sei bem como me virar. Se ele está permitindo que eu faça entrevistas por e-mail, vou tentar aproveitar. Mas não agora, para não desgastar o conteúdo. No ano que vem, quando eu tiver um aprofundamento maior das questões mal-explicadas, eu envio uma leva de perguntas. Pode ser?

Beijos e abraços,

Chris

E o ano terminou assim, comigo casada em uma festa linda nordestina que eu produzi com a ajuda de Marco e de meus pais - principalmente da minha 
mãe, dotada de habilidades manuais e uma pessoa de ótimo gosto - e com o clima azedo entre eu e a família Ramalho. Apesar disso, eu ainda amava a história de Zé Ramalho e me sentia meio traída, como Mário de Andrade em relação a São Paulo:

Pretendo, se Deus quiser, escrever um poema 'Paulicéia reconquistada'. Significação: eu, reposto dentro de mim mesmo, já calmo e paciente, conscientemente corneado pela amante, mas ainda amoroso, quase confiante, gritando de meu posto meu amor pela cidade. (ANDRADE, 2001, p. 46)

Dois dias depois do casamento, eu e Marco embarcamos para a lua de mel em uma viagem de 45 dias pela Ásia. Se para Graciliano era uma brincadeira, para mim, acordar na China era um projeto muito sonhado. Aproveitando-me da fé que sempre tive no budismo, apesar de minha formação católica, orei em todos os templos pelos quais eu e meu marido passamos nos seis países que visitamos. Eu só pedia para que acontecesse o que fosse melhor para mim. Ao mesmo tempo em que comecei a querer não contar mais com Zé Ramalho para o sucesso do meu projeto, o distanciamento me fez começar a perceber que de fato eu não precisava tanto dele quanto eu imaginava. Primeiro porque eu já tinha muitas e muito boas entrevistas. Ele já tinha deixado claro que não fazia questão de acompanhar meu processo de escrita, o que me permitiria a liberdade sonhada pela maioria dos biógrafos com autorização. Roberta havia aberto a possibilidade de eu enviar e-mails com as dúvidas que tivesse e eu poderia fazer isso quando começasse de fato a organizar o que já tinha escrito e escrever o que faltava. Por fim, concordei que dependia de mim encontrar as pessoas que faltavam para concluir certas histórias mal contadas. 


\section{Investida agressiva, retorno mais rápido}

Decidi que, em 2014, eu não procuraria mais por Zé Ramalho ou por Roberta, mas seguiria correndo atrás das fontes mais difíceis de forma mais agressiva. Comemorando por ter sido contemplada com uma bolsa de estudos do CNPq, financeiramente eu estaria preparada para o investimento na finalização da minha pesquisa. Para conseguir escrever uma boa dissertação ou a biografia que eu julgasse perfeita, se fosse o caso de alcançar esse objetivo, organizaria essas entrevistas com a ajuda de produtores - na Paraíba, Elinaldo Rodrigues, o diretor do documentário biográfico de Zé, e, no Rio, Mariana Dantas, jornalista e tecladista do Press Play. E contrataria digitadores para transcrever as mais de 100 horas de conversas, algumas que eu já tinha tido e outras que ainda teria durante minha passagem por Brejo do Cruz, Campina Grande, João Pessoa, Recife e Olinda. No ano em que escrevi alguns releases para gravadoras, fiz diversas coberturas para o GarotaFM, atuei como produtora em eventos da cantora e atriz Letícia Persiles - com quem tinha começado a trabalhar informalmente em 2013 - e aceitei o posto de pesquisadora, entrevistadora e roteirista do Mulheres do Brasil - programa sobre cantoras compositoras exibido pelo canal a cabo Bis - eu consegui encontrar mais de 50 personagens importantes para a biografia de Zé.

A Copa do Mundo, passei pesquisando a vida e a obra de Zé Ramalho no Nordeste, onde conversei com uma série de pessoas, inclusive a tia Zélia e Hugo Leão novamente e os dois filhos mais velhos de Zé. Além do investimento financeiro que fiz na produção, cujo retorno foi aceitável, mas não completamente satisfatório, porque nem todas as fontes se colocaram à disposição, investi muita energia emocional e até física no projeto. E nem tudo saiu como eu gostaria. Em João Pessoa, Ísis, a primeira mulher de Zé Ramalho, e os ex-parceiros e agora ex-amigos Onaldo Mendes e Eduardo Stucker chegaram a marcar encontros comigo através de Elinaldo, mas desmarcaram e 
não cederam a todos os apelos que fiz para convencê-los da importância de ouvir as histórias sob o ponto de vista deles. Em compensação, em minha passagem por Brejo do Cruz, além das casas onde moraram os avós de Zé, conheci a pedra de turmalina e o terreiro da usina onde o compositor diz, na letra de "Avôhai", que se criou. Eu e Marco, que me acompanhou nessa jornada pelo sertão, ficamos hospedados na casa de Rozilda Dutra, tia de uma grande amiga. Roni Filgueiras foi subeditora de O Globo Online quando eu era estagiária do site e acompanha cada passo meu desde então. Fazia pouco tempo que eu tinha descoberto que sua família era de Brejo do Cruz e, quando contei que viajaria para lá mesmo sabendo que não há hotéis na cidade de cerca de 15 mil habitantes, ela tratou de me apresentar à tia.

Chegando em Brejo, lembrei de Cabo Verde por causa da praça, da Igreja e da boa vontade das pessoas em nos receber e nos ajudar. Além de outros habitantes orgulhosos por morarem na cidade onde Zé Ramalho nasceu, contamos com o apoio de Aurílio Santos, um fã que há anos tentava manter de pé o Acervo Cultural Zé Ramalho - infelizmente, dias antes de eu chegar na cidade, o espaço foi fechado por falta de incentivo - e que sabe bastante sobre a carreira do ídolo, além de conservar todo o material que expunha no museu. Ele nos levou até Frutuoso Gomes, cidade do Rio Grande do Norte a mais ou menos 60 quilômetros de Brejo, para conhecer outro fã colecionador de documentos e artigos relacionados a Zé: Rivanildo Alexandrino me abriu seu arquivo, um quarto com artigos que ele juntou ou comprou pela internet ou de pessoas que se relacionaram com seu ídolo. Essa dupla merece muitos agradecimentos, afinal, com fotografias dos recortes de jornais, discos piratas e tantas coisas que eles tinham, saí de lá bem mais segura de que material era o que não ia faltar.

Logo no meu primeiro dia em João Pessoa, vivi uma experiência tragicômica que acabou ganhando quase 90 "curtidas" e muitos comentários no Facebook, rede social na qual eu de vez em quando registro parte da minha saga. Ilustrado por fotos do trajeto que fiz do bairro de Jaguaribe, onde moram Pedro Osmar e sua filha Bebel, à cidade de Lucena, onde fica a casa do irmão de Pedro, o também músico Paulo Ró, o texto publicado foi o seguinte: "Ser jornalista/pesquisadora é começar o dia levando um bolo e terminá-lo enterrando 
uma gata. Ou seja... É sair cedo para uma entrevista e descobrir que o cara esqueceu de você e saiu para uma filmagem. É ser convidada por ele para ir ao seu encontro e sair pela cidade que você não conhece acompanhada da filha dele. É pegar uma balsa para outro município, para onde ele iria com a outra equipe e almoçar na casa do seu irmão. É descobrir que deu problema na filmagem e que ele não irá mais para lá e voltar à casa dele, tendo que mudar de ônibus porque o seu quebrou no caminho. É conseguir começar o papo já de noite e assistir à gata da filha do cara sendo atropelada. E é, por solidariedade $e$ amizade (porque depois de um dia inteiro com esse amor de moça, viramos melhores amigas), iluminar com a lanterna do telefone celular o buraco feito no jardim por um músico que visitava meu entrevistado. E é tentar segurar o riso sem sucesso ao ouvir sua fonte dizer: 'O cara é músico, já foi pedreiro e, agora, com essa enxada na mão, virou coveiro.' Apesar se tudo, amo minha profissão!"

No primeiro semestre, eu já tinha estado com Alceu, profissionais das gravadoras, o primeiro empresário dele, Carlos Alberto Sion, Zeca Baleiro - que já foi parceiro e gravou, em maio de 2014, um DVD tributo a Zé Ramalho - e outros. Na volta do Nordeste, estive com Geraldo Azevedo, Jards Macalé, e, depois de uma investida agressiva, com Elba Ramalho. Passei muitas horas com Amelinha e telefonei para pessoas de fora do Rio, inclusive o baiano Bell Marques, líder do banda Chiclete com Banana, o responsável por impulsionar a canção "Frevo mulher" em 1979 ao tocá-la em um trio elétrico durante o carnaval de Salvador. Em São Paulo, Zé do Caixão encontrava-se internado e não pôde falar comigo por telefone, mas sua filha, Liz Marins, que teve um breve affair com Zé no início de 1984, ano em que ela estampou a capa do álbum "Por aquelas que foram bem amadas ou pra não dizer que não falei de rock”, concedeu-me uma ótima entrevista. Com uma ajuda do Baleiro, Geraldo Vandré abriu uma exceção e falou comigo por telefone, mas não conseguiu resgatar da memória nem episódios vividos ao lado de Zé nem confirmações de histórias contadas por meu biografado. Troquei e-mails com outros personagens importantes, como Paulo Coelho, e encontrei a ex-mulher de Raul Seixas, Kika Seixas.

Zé Ramalho cultiva até hoje um carinho enorme por Raul, com quem havia combinado de fazer um disco após a virada do século. Por causa da morte do 
roqueiro baiano, ele esperou até 2001 para gravar um tributo ao amigo, que ganhou o nome de "Zé Ramalho canta Raul Seixas". Só que uma briga entre a ex-mulher, detentora de parte dos direitos de Raul, e Paulo Coelho, parceiro dele em suas principais composições, acabou fazendo com que Zé tivesse que desistir de várias faixas já gravadas e escolher outras que não tivessem o escritor como coautor. Eu sabia que esse era um tema delicado, mas que eu precisaria abordar na biografia ouvindo todas as partes. A história contada por Zé, eu já sabia. Fui atrás de Paulo e de Kika e, ao contrário do que aconteceu com muitas outras fontes, surpreendi-me com a rapidez e a disponibilidade de ambos para me ajudar. Eu jurava que teria problema na hora de conferir as informações, mas, pela primeira vez durante esse processo, ouvi a mesma história contada da mesma forma por três fontes diferentes. Confirmei a informação que Hérica Marmo, autora de um livro sobre a faceta compositor do escritor chamado "A canção do mago", a quem ajudei durante o processo de pesquisa, havia me dado de que Paulo costuma ser uma fonte confiável. O que mudou foi apenas o comentário de cada um sobre sua própria atuação no caso.

\author{
De: Paulo Coelho \\ Para: Christina Fuscaldo \\ Cc: Renato Pacca \\ Enviadas: Domingo, 3 de Agosto de 2014 19:35 \\ Assunto: Re: Sobre Zé Ramalho, Raul Seixas e você
}

Christina,

Boa noite!

Indo direło ao assunto... Na época (não me lembro quando), Chitãozinho e Xororó queriam gravar "Medo da chuva". Eu liberei. De repente, fui avisado que a música tinha sido proibida por uma das outras partes. Fiquei surpreso. Fui apurar e vi que Kika havia vetado a gravação de todas as minhas músicas com Raul, porque queria que Zé tivesse exclusividade. Naquele mesmo dia, pedi ao meu advogado que, se era assim, que vetasse para todo mundo. Zé saiu prejudicado. Meu advogado que agiu proibindo as músicas para todo mundo (não apenas para 
o Zé), Dr. Renato Pacca, está em cópia aqui e poderá ser mais preciso, caso necessite de mais detalhes. As músicas ficaram sem autorização durante um ano. A partir daí, nunca mais tive problema de liberar seja o que for para 0 artista que quiser.

Abraços,

Paulo Coelho

Kika confirmou a versão de Paulo sem eu precisar contá-la. O que consegui a mais, durante a visita que fiz a ela em seu apartamento, foi o porquê de ela ter vetado a gravação por Chitãozinho \& Xororó, que acabaram conseguindo a autorização anos depois: "Todo mundo me ligava perguntando se eu estava louca, dizendo que a dupla vendia um milhão de cópias e Zé, cerca de 30 mil. Mas eu não podia fazer uma coisa daquelas com o Zé, a gente tinha combinado há dois anos. Se os sertanejos lançassem na mesma época, o disco do Zé não ia conseguir ter a mesma repercussão. Fora isso, eu sentia que era preciso respeitar um pouco o estilo do Raul, afinal, naquele momento, sambista, pagodeiro, todo mundo queria gravar Raul. Por quase dez anos, Raul ficou meio esquecido e Zé foi o primeiro a vir falar comigo que queria fazer o disco por causa da história que ele viveu com o amigo. Em 1984, cinco anos antes da morte de Raul, eles passaram um fim de semana inteiro no apartamento do Zé, tocando rock'n'roll. Tenho isso registrado em vídeo e é a coisa mais linda! Raul adorava roqueiros como Erasmo Carlos e homens como Luiz Gonzaga. Para ele, Zé Ramalho era essa junção do rock com o Nordeste que ele gostava. Tinha tudo a ver essa gravação!"

Uma das últimas entrevistas que fiz no ano foi com Fagner, o nordestino preferido do meu pai. Em seu apartamento, no mesmo prédio de Zé Ramalho, lembrei de quando o entrevistei por telefone para o jornal Extra e ele disse que minha voz parecia a de Patrícia Pillar. Comentei que, em casa, diziam que eu parecia com ela na novela O Rei do Gado. Falamos sobre o DVD que ele gravou junto a Zé no final de julho e sobre todos os outros encontros que os dois tiveram. A um mês das eleições, o cearense me convidou a assistir o debate dos candidatos à Presidência e, após eu pedir para tirarmos uma foto juntos, ele me 
deu um disco seu recém-lançado e autografou um para meu pai. Em vez de escrever uma matéria ou uma resenha tradicional, fiz para o GarotaFM um artigo autobiográfico intitulado "Fagner: um encontro com o passado e com o presente"37, no qual eu lembrava que "Canteiros" sempre permeou minha memória afetiva por causa da paixão do meu pai pela canção, que acabou proibida e retirada do LP "Manera frufru manera", após ser descoberto nela um trecho do poema "Marcha", de Cecília Meireles. Meu texto ganhou como resposta uma carta de Cornélio Melo, colaborador do blog desde 2013 junto a Luiz Antônio Mello e outros. Publicada lá também, a mensagem intitulada "Fagner: 'Manera fru fru manera' de pai para filha" terminava com meu pai me agradecendo por eu ter seguido seus passos:

\begin{abstract}
Valeu, Chris, por ter escolhido trabalhar com música, ainda que através do jornalismo musical, praticando-a também como hobby (adoro você, tanto cantando "Fênix" com sua banda ECT quanto cantando "We Can Work Out" comigo ao violão) - assim como aconteceu com seu pai. E obrigado por estar sempre trabalhando com aqueles que foram e ainda são meus eternos ídolos, com os quais tanto aprendi de música ao longo desses anos. ${ }^{38}$
\end{abstract}

Menos emocionante, mas não menos importante, a última entrevista mesmo foi com Elba Ramalho. Depois de uma luta de cerca de um ano e meio, consegui encontrá-la após ameaçar seu empresário, dizendo que não só publicaria as histórias mais terríveis dela contadas a mim como também colocaria, em minha introdução, um aviso de que ela se negou a dar seu depoimento. Também expus no Facebook minha felicidade em vencer mais esse obstáculo: "Mais uma conquista, hoje, para o livro sobre Zé Ramalho! Depois de um ano e meio tentando entrevistar Elba Ramalho, ela (que estava enrolada, mas acho que também preocupada, afinal nunca teve uma relação tão boa com a imprensa) me recebeu em casa e foi se soltando aos poucos, chegando ao ponto de sair da vibração 'estresse' / 'seriedade' (vale lembrar que ela estava correndo, com mil compromissos) e terminar o papo relaxada e sorrindo muito.

37 FUSCALDO, Christina. Fagner: um encontro com o passado e com o presente. Disponível em <http://garotafm.com.br/2014/09/18/fagner-um-encontro-com-o-passado-e-com-opresente/> Acesso em: 20 mar. 2015.

38 MELO, Cornélio. Fagner: "Manera fru fru manera" de pai para filha. Disponível em $<$ http://garotafm.com.br/2014/09/18/fagner-manera-fru-fru-manera-de-pai-para-filha/>. Acesso em 20 mar. 2015. 
Acho que mostrei a ela o quanto valorizo a cultura popular e a música do Nordeste. Acho que convenci de que sou uma jornalista sem preconceitos e sem maldade. Saí de lá com as portas abertas para outras entrevistas e feliz por ter conseguido, mais uma vez, fazer o meu trabalho direitinho, como aprendi com alguns dos meus mestres."

Definitivamente, 2014 seria o ano em que eu planejaria me livrar de vez desse projeto, virando ele um trabalho acadêmico ou a biografia que eu tanto tinha sonhado escrever. E acabou sendo o ano em que fui procurada por duas editoras, uma grande e cheia de estrutura, porém que dava menos atenção a cada lançamento, já que fazia muitos por ano, e uma pequena, que investia e acompanhava de perto cada lançamento e já tinha provado ter uma boa distribuição. Uma oferecia ajuda financeira, o tal adiantamento, coisa que, àquela altura, eu não precisava mais, afinal, eu havia feito os gastos maiores. A outra não tinha recursos, mas garantia um contrato mais generoso já que eu tinha investido sozinha no projeto. Depois de sete anos congelando projetos, o mercado editorial voltou a se abrir para novas propostas após a rápida ascensão e derrocada do Procure Saber ${ }^{39}$, grupo liderado pela empresária de Caetano Veloso, Paula Lavigne, que rebocou não só o ex-marido como Gilberto Gil, Chico Buarque e Djavan para acompanhá-la em suas ações em prol da criação de um Projeto de Lei que proibisse as biografias não autorizadas. Fiquei de pensar. Através de seu produtor e assessor Julio Moura, Alceu Valença enviou uma carta aos jornalistas defendendo as biografias não autorizadas.

\author{
De: Julio Moura \\ Para: Jornalistas \\ Enviadas: Quarta-feira, 9 de Outubro de 2013 18:24 \\ Assunto: Alceu Valença e a polêmica das biografias
}

Pare, repare, respire, reveja, revise sua direção... Eu compus essa letra para o disco "Maracatus, batuques e ladeiras", que lancei em 1994. Desde ontem, um assunto tomou conta

39 Conheça a polêmica. Disponível em <http://oglobo.globo.com/infograficos/batalhabiografias/>. Acesso em: 15 jan. 2015. 
dos meus pensamentos. No fim da manhã, recebi um telefonema de uma jornalista que solicitava minha posição acerca da polêmica que vem acontecendo em torno da autorização ou não de biografias. Como já estava na hora de buscar meu filho no colégio, pedi para ela me ligar à tarde. Dali em diante, fiquei remoendo o assunto e aguardando seu novo contato, o que não veio a acontecer. A questão não é simples. Pesei costumes e comportamentos. Refleti sobre o tempo e a história. Considerei valores e conceitos. Cheguei a uma conclusão que envolve quatro pontos essenciais: Ética. $O$ assunto até parece démodé, mas deveria estar intrinsecamente no centro de diversas situações que vivemos hoje em dia. Inclusive, neste caso. Óbvio que o conceito é subjetivo e, até, utópico. No entanto, sem a sua prática, o desequilibrio é evidente.

Fala-se muito em biografias oportunistas, difamatórias, mas acredito que a grande maioria dos nossos autores estão bem distantes desse tipo de comportamento. Arrisco em dizer que cerceá-los seria uma equivocada tentativa de tapar, calar, esconder e camuflar a história no nosso tempo e espaço. Imaginem a necessidade de uma nova Comissão da Verdade daqui a uns 20 anos... Assim entramos em outro conceito, igualmente amplo, delicado e precioso: liberdade de expressão. Aliás, tão grandioso que deveria estar na frente de qualquer questão. O que é pior: a mordaça genérica ou a suposta difamação? Eficiência e celeridade processual são princípios que devemos reivindicar para garantia dos nossos direitos. Evitar a prática de liuros ofensivos e meramente oportunistas através do Poder Judiciário é uma saída muito mais eficaz e coerente com os fundamentos democráticos. Definitivamente, a questão não é financeira. A ideia de royalties para os biografados ou herdeiros me parece imoral. Falem mal, mas me paguem...(?) É essa a premissa??? Nem tudo pode se resumir ao vil metal!

Com todo o respeito pelas opiniões contrárias, este é o meu posicionamento. Viva a democracia!

Alceu Valença 
Ainda no embalo da polêmica, Zé Ramalho declarou, em uma entrevista ao jornal O Estado de S.Paulo (também chamado de Estadão), não se opor:

Quem quiser escrever sobre mim, pode pedir minha autorização ou não. Agora, quem vai ler ou comprar é o que importa. Imagina uma pessoa comprar um livro biográfico cheio de mentiras exatos que nunca ocorreram! Se é isso que vai fazer sucesso, virar best-seller, estarão comprando um pacote de mentiras, ou seja, estarão sendo enganados. ${ }^{40}$

Ao ser perguntado se foi procurado pelo Procure Saber e se sentia representado pelo grupo, Zé Ramalho foi curto e grosso:

\begin{abstract}
Nunca! Nunca procurei saber de nada! É arrogante e equivocado esse posicionamento. Nenhuma reivindicação é unânime! Os artistas têm cabeças diferentes. Alguns podem pensar parecido, mas ninguém jamais verá unanimidade nestas questões. Hoje em dia, pode-se quase tudo. Em tempos de internet, onde o anonimato é uma arma para se criticar, derrubar, execrar, não pode cobrar dos artistas, como a imprensa fez, essas posições. Eu corri por fora dessas questões, porque eu já sabia, antes de procurar! Em 2013, Henri Koliver, escritor e psicólogo francês, escreveu um livro sobre mim, mistura de biografia e entrevistas, "Zé Ramalho - O poeta dos abismos" (Editora Madras). Ele teve autorização. Mas tenho também livros que escreveram sobre mim sem a minha autorização. Fazer o quê? Difícil é se comprar livro, hoje em dia. Difícil é ter alguém para ser biografado e alguém se interessar por aquela vida.
\end{abstract}

Achei a postura de Zé interessante, mas meio pessimista em relação ao público consumidor de livros. Novamente, lembrei de Graciliano: "Creio que em Maceió não tenho amigos que se possam interessar tanto pela minha vida e pelo meu bem-estar." (RAMOS, 2011, p. 37) É fato que a biografia é um dos gêneros literários menos vendidos no Brasil, mas há, sim, um nicho de leitores interessados. Eu mesma posso dizer isso, afinal, vira e mexe recebo e-mails de fãs de Zé perguntando quando terei a história de seu ídolo escrita. Eu estava distante do meu biografado, mas gostei de saber que ele não tinha se bandeado para o lado dos artistas que travaram uma luta contra jornalistas e historiadores, esses que atacaram com força o Procure Saber em matérias de revistas e

40 NOBILE, Lucas. A volta do que não foi. Disponível em < http://cultura.estadao.com.br/noticias/musica,a-volta-do-que-nao-foi,1136977> Acesso em: 03 mar. 2014. 
jornais, publicações em blogs e redes sociais etc. Engraçado é que, enrolada com meus afazeres e com a pré-produção da viagem que faria em julho para o Nordeste, só fui ler a entrevista de Zé no segundo semestre. E, em maio, usando uma linguagem mais acessível para os leitores do jornal O Dia, eu dei uma entrevista ao jornalista Leandro Souto Maior para o Caderno D sobre a questão das biografias. Eu ocupava, agora, uma outra posição: não era uma biógrafa, não sabia se o seria um dia, mas graças a tudo o que vinha vivenciando e estudando no mestrado, já tinha bagagem suficiente para disseminar meus conhecimentos sobre o gênero. A pergunta era sobre as vantagens da aprovação do Projeto de Lei que liberava a produção de biografias não autorizadas. O texto que enviei a Leandro, na íntegra, foi assim:

\author{
Rio de Janeiro, 14 de maio de 2014. \\ Leandro,
}

Consigo ver duas vantagens das quais poderei me aproveitar para finalmente terminar e lançar a biografia de Zé Ramalho, para a qual ganhei autorização do próprio em 2007 e na qual estou trabalhando de forma independente desde 2010: acho que será mais fácil conquistar a confiança de personagens que ainda não aceitaram conceder entrevistas a mim (nenhum disse que é por isso, mas eu desconfio que eles tenham medo de não poder mudar a maneira como escreverei a história); acho que haverá a abertura do mercado editorial, o que fará com que as editoras se sintam

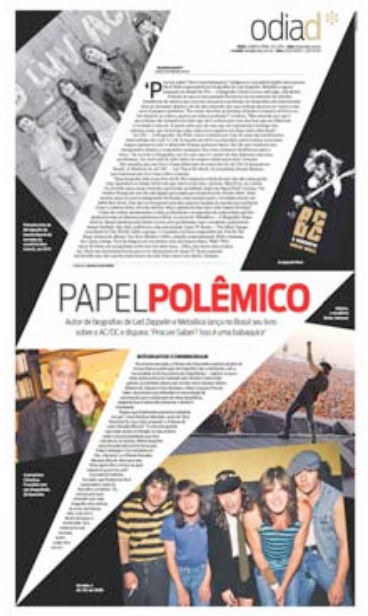
mais seguras para receber um liuro que não thes renderá processos judiciais. Como disse, minha biografia é autorizada, mas esses são os dois motivos que me impedem de terminar esse trabalho ao qual estou me dedicando com afinco. 
Muito por causa dessa discussão, eu, que sou formada em Jornalismo e Letras, decidi ingressar no mestrado para tentar entender o que torna a biografia um gênero tão polêmico e, também, para me ajudar a finalizar o liuro. Lá, estou conseguindo escrever mais do que estava antes. Tenho um orientador no papel de editor e muito mais entendimento da importância da biografia, um dos documentos históricos a que todo e qualquer povo deve ter acesso para entender a sua própria história. Vetar a publicação de uma biografia é censurar a própria história e colaborar com a formação de cidadãos alienados.

Acho importante o biografado ter direito a resposta, mas os países desenvolvidos já provaram que o que faz o mercado de biografias prosperar é justamente a disputa entre biógrafos por escrever a methor biografia. $O$ que o leitor, o editor e o biografado precisam entender de uma vez por todas é que a minha biografia vai ser a minha leitura da história de Zé Ramalho. Traçando um perfil pessoal e profissional, eu me coloco inclusive como personagem coadjuvante dessa história que, se for mal contada, quem paga mico sou eu.

Um abraço da amiga,

Chris Fuscaldo

\section{O trecho publicado foi:}

A jornalista Christina Fuscaldo, que finaliza um livro (autorizado) sobre Zé Ramalho, completa: "Os artistas precisam entender que cada biografia será a leitura do autor da história dele, e ele tem o direito de lançar a versão dele. Se a história for mal contada, quem paga mico sou eu." ${ }^{41}$ 


\title{
29 Tá tudo mudando
}

Parece que, quando a gente resolver se desapegar, os ventos mudam e o que estava empacado começa a andar. Durante minhas pesquisas na Paraíba, desconfiei que Zé estava acompanhando meus passos, afinal, tia Zélia não me receberia novamente nem seus filhos mais velhos me concederiam entrevistas sem a aprovação dele. Lembrei de uma frase de Janet Malcom, que diz que "os familiares são os inimigos naturais dos biógrafos; são como as tribos hostis que o explorador encontra e precisa submeter sem piedade a fim de se apossar de seus territórios." (MALCOLM, 1994, p. 17). Não acho que houve animosidade, mas as declarações eram sempre pouco aprofundadas. No caso da tia Zélia, como eu já vinha com uma outra bagagem, comparando com a que eu tinha em 2010 , consegui ir um pouco mais além, principalmente na segunda vez em que fui até a sua casa. Mas não perguntei por Zé nem por Roberta no presente. A Onaldo Mendes, eu disse que não passaria recado algum quando me sugeriu que eu dissesse a Zé que ele estava chateado por não ter sido convidado para uma festa na casa que o amigo mantém em João Pessoa e na qual a família Ramalho se reúne no verão. A história me pareceu um grande mal-entendido.

\author{
De: Christina Fuscaldo \\ Para: Onaldo Mendes \\ Enviadas: Segunda-feira, 7 de Julho de 2014 1:10 \\ Assunto: Re: Biografia Zé Ramalho
}

Olá, Onaldo!

Obrigada pelo e-mail. Parece que se preocupou comigo pelo menos um pouquinho. Agradeço pelo material também, apesar de eu já ter esse texto. Mas, olha, suas histórias contadas 
são muito melhores e mais completas do que essas editadas que estão nos liuros e filmes já existentes. Nem movimentando toda a Paraíba eu consegui te sensibilizar, né? Puxa...

O que me deixa mais angustiada é saber que daqui a pouco você fará as pazes com Zé e não vai dar mais tempo de melhorar a narrativa de uma época essencial, não só para a história de Zé como para a história da cultura da Paraiba! E eu nem sei se Zé está colocando tanto peso assim nessa briga de vocês... Foi ele mesmo quem sempre me indicou você como um dos amigos mais próximos... Onaldo, quando você ligou dizendo que gostaria de vê-lo, para preservar o marido recém-operado, Roberta pediu que não fosse para que Zé não tivesse grandes emoções. Hugo apareceu lá de surpresa e é claro que, nesse caso, ninguém ia bater com a porta na cara dele. Pelo que entendi, não houve uma festa.

Esse meu trabalho é autorizado, mas isso não significa que Zé está acompanhando o processo. Estou fazendo tudo sozinha, investindo a bolsa de estudos do mestrado para a finalização da pesquisa. Você não pode imaginar o esforço que venho fazendo para conseguir contar uma história que julgo importante para a música brasileira. E você é parte dela! Como te deixar de fora? Pode me dizer? Fiquei mais triste ainda depois que soube que Eduardo Stucker desmarcou o papo comigo porque só fala se você estiver junto. Fiquei sem dois personagens importantes por causa de um orgulho que respeito, mas não entendo. Vou embora na terça bastante decepcionada... Não farei o relato a Zé nem a Roberta porque, como eu disse, eles não estão participando do processo e nosso combinado é eu não importunar eles. O que ficam são histórias mal contadas, contadas por outros, sem as versões de vocês. Pense nisso, por favor?

Amanhã, vou a Recife para algumas entrevistas, mas de noite já estarei de volta e com tempo livre. Na terça, tenho uma entrevista às 1 h e devo estar liure entre 13h e 17h. Me despeço aqui, ainda na expectativa de você mudar de ideia.

Abraços! 
Ele não mudou de ideia. $E$ a verdade é que eu também não queria contato com meu biografado. Tinha decidido escrever o livro como se ele estivesse morto. Vivo, para mim, eu só o queria no palco. Assim como a música para Keith Richards, a biografia de Zé Ramalho tinha virado um vício do qual eu precisava me livrar: "A bem da verdade, era uma droga muito mais forte do que heroína. Eu consegui chutar a heroína; mas não consegui me desvencilhar da música. Uma nota leva a outra e você nunca tem exatamente certeza do que vem depois." (RICHARDS, 2010, p. 75) Pouco depois do retorno ao Rio, aceitei o convite da Sony Music para assistir à gravação do DVD "Fagner \& Zé Ramalho - Ao vivo" no dia 30 de julho, no Teatro Net, em Copacabana. Escrevi uma resenha para o GarotaFM, na qual eu comentava o suposto desentendimento ${ }^{42}$ entre os dois artistas, situação que ficou evidente no palco quando Zé saiu deixando Fagner entoando um sucesso seu sozinho.

Três dias de gravação e o cansaço seguindo em ordem crescente. Foi assim a semana de Fagner e Zé Ramalho, que se juntaram para gravar um DVD em dupla. No palco do Teatro Net, em Copacabana, de segunda a quarta, a dupla apresentou canções de seus repertórios, acertando e errando até ajustar o roteiro que estará no novo produto a ser lançado pela Sony Music. Cansativo, mas nada excepcional, afinal, é o que acontece em quase toda gravação ao vivo. Apesar das dificuldades, o resultado final com certeza será um presente para os admiradores dos cantautores e para os fãs da verdadeira música sertaneja do Brasil. ${ }^{43}$

E foi esse o texto que fez com que Zé tentasse uma nova reaproximação, mais uma vez através de Roberta.

42 FORTUNA, Maria. Zé Ramalho e Fagner se estressam em show. Saiba por quê. Disponível em <http://oglobo.globo.com/blogs/blog gente boa/posts/2014/08/01/ze-ramalhofagner-se-estressam-em-show-saiba-por-que-544472.asp> Acesso em: 01 ag. 2014.

43 FUSCALDO, Christina. Zé Ramalho e Fagner gravam em DVD a verdadeira música sertaneja. Disponível em <http://garotafm.com.br/2014/08/01/ze-ramalho-e-fagner-gravam-em-dvda-verdadeira-musica-sertaneja/> Acesso em: 02 ago. 2014. 
De: Roberta Ramalho

Para: Christina Fuscaldo

Enviadas: Sexta-feira, I de Agosto de 2014 18:25

Assunto: Fagner e Zé

Oi Chris, tudo bem?

Lemos a sua matéria. Ficou ótima! Você percebeu tudo, inclusive o mau humor do Zé na hora do bis. Ele detesta ter que refazer uma música, principalmente quando ele não errou, quando há uma falha de luz, ou de músico etc... É o jeito dele, que você já conhece... Só queria te dizer que, em todos os dias, a roupa deles era exatamente a mesma. Na segunda-feira, eles passaram o som mais cedo, com outra roupa, mas depois gravaram com as roupas do show. Talvez você tenha visto alguma foto deles na passagem de som.

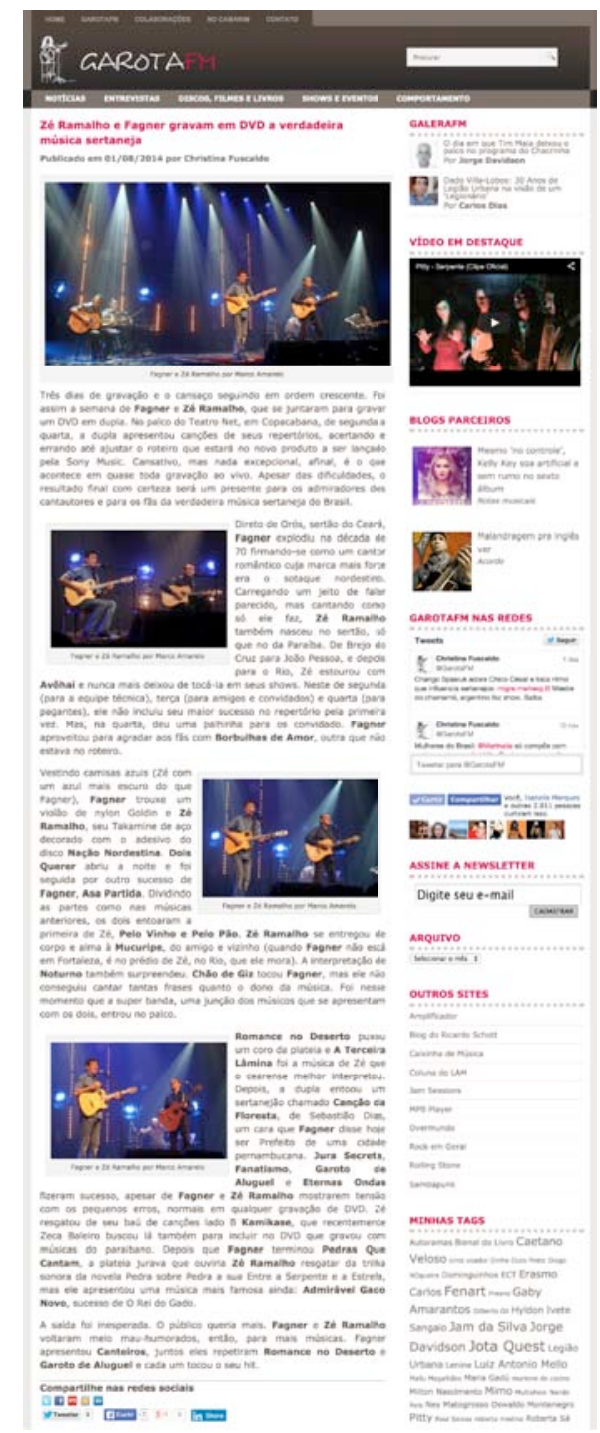

P.S. Deu tudo certo na Paraiba? Falamos com o Christian antes de ele te receber, pedimos que desse toda a atenção. Ele é muito receptivo, fala sobre o pai com gosto e orgulho. 
Eu tinha cometido um pequeno erro ao escrever sobre a cor da roupa da dupla por causa de uma imagem que vi dos dias anteriores. Mas, imediatamente, respondi o e-mail de Roberta agradecendo pela correção, comentando que o mergulho na Paraíba foi um sucesso e sugerindo que seria interessante entrevistá-la também. Avisei que passaria três meses na Argentina devido à bolsa que me foi contemplada pela Capes para um intercâmbio sanduíche na Universidad Nacional de Rosario e que continuaria a escrita do livro lá. Planejei até investigar o paradeiro de Belchior ${ }^{44}$ para ver se conseguia uma entrevista com o cantor, desaparecido desde 2009 e, segundo fontes mais próximas, exilado em algum dos países vizinhos da América do Sul. Só que não deu tempo e continuei com a única lembrança que eu tinha do compositor cearense, segundo Roberta, primo de sua mãe: uma foto que fiz segurando a mão do cantor dentro de um avião, na volta para casa, no dia seguinte de entrevistá-lo para o jornal Extra em um festival no Rio Grande do Sul. Por causa das agendas, eu e Roberta adiamos o encontro para 2015. E, entre agosto e 9 de outubro, além de fazer outras entrevistas, juntei todo o material referente a Zé Ramalho que eu tinha em livros, folhas de jornal, fotocópias e HDs e coloquei tudo em uma mala, que ficou dez quilos mais pesada do que a companhia aérea permitia para o embarque. Seis dias antes de viajar, no aniversário de 65 anos do meu biografado, deixei em sua portaria uma cópia da carta da tia Zélia e uma minha. A ideia não era mais sensibilizá-lo, mas avisá-lo de que eu tinha mudado.

Rio de Janeiro, 03 de outubro de 2014.

2é,

Já faz cinco anos que the escrevi um e-mail desejando um feliz aniversário e lamentando não estar te dando de presente a sua biografia autorizada. Desde quando aceitou a proposta que fiz a você, meu maior desejo era aproveitar uma "data redonda" como gancho para fontes não encontradas durante o período de pesquisa. 
divulgar sua trajetória para todo o Brasil. E, quando enviei aquela carta eletrônica, você completava 60 anos. Apesar de ter planejado esse projeto no fim da década de 90, só pude ter acesso a você como jornalista em 2005. Foi neste ano que te mandei aquele livrinho. Lembra? Em 2007, você me convidou para fazer aquele roteiro de entrevistas para o DVD "Parceria dos viajantes" e, pegando-me de surpresa, disse "sim". Você não deve conseguir imaginar o turbilhão de emoções que circularam por dentro do meu corpo quando te ouvi dizer que abriria seu baú de memórias para mim. Trocamos alguns outros e-mails. $E$ cartas. Junto com os presentes que costumava te dar anualmente, sempre no dia 3 de outubro, enviei algumas escritas à mão. Sou cria do jornalismo online, sou blogueira, tenho perfis nas redes sociais mais populares, mas gosto de manuscritos! Sinto um certo vazio pela falta do acesso que eu tive, por muitos dias da minha vida, à leitura das cartas. Elas me permitem analisar um pouco a personalidade de quem as escreve, acho que através da letra. É muito dissonante para mim a forma como as adolescentes do século XXI estão crescendo, sem saber se conseguem identificar se a amiguinha é relaxada, metódica ou se faz o tipo "de bem com a vida". Eu tinha mania de descrever cada uma das minhas amigas a partir das coisas que elas escreviam nos meus cadernos, agendas e nas cartas que me enviavam. Eu só não conseguia descrever a mim. Mas hoje, olhando para trás - e analisando palauras que escrevo com essa minha letra meio feia - talvez consiga enxergar a solidão na qual acho que sempre vivi. Eu falei "acho". Difícil saber o que é a solidão para cada um, né?

Tem uma coisa que nunca te falei... Há um caderno guardado na casa dos meus pais com as primeiras cartas que escrevi a você. Comecei a dialogar com minha pesquisa em 1999 e já recorri a ele diversas vezes desde que iniciei o mestrado para buscar informações que me ajudassem a embasar as teorias que fui tentando formular ao longo dos últimos dois anos, desde que desisti de só biografar você para poder estudar você e o porquê de eu tê-lo escolhido para ser meu biografado. No primeiro semestre, aprofundei-me nas teorias da Literatura com Júlio, meu orientador, mas me descobri nas aulas da Daniela Versiani sobre a escrita de si. Foi lá que comecei a questionar o gênero biográfico e aplicar mais a crítica literária à vida. Lendo um texto 
sobre uma conferência dada em 1969 por Michel Foucault intitulada "O que é um autor?", confirmei a sensação que já tinha de que eu não sou uma autora, mas estou autora. A questão da articulação entre diversos gêneros discursivos contemporâneos, ligados aos relatos de experiências pessoais e à exposição pública da intimidade, também entraram em pauła. A escritora e professora argentina Leonor Arfuch comenta, em seu liuro "Espaço biográfico: Dilemas da subjetividade contemporânea”, a transformação que considera decisiva nas formas de enunciação do eu devido ao avanço da midiatização e o surgimento das tecnologias de transmissão ao vivo, que retiraram as narrativas biográficas das cartas e dos diários e fizeram com que fossem explorados em diferentes suportes e em escala global. Discussões em torno da fabricação de um passado através da dificuldade de um sujeito de lidar com a própria memória também foram constantes em aulas como as da Daniela e as do Júlio, dois professores que acabei seguindo do início ao fim do curso. Foi muito importante também, para mim, o contato com o pensamento em torno das artes proposto por professores como Mariana Simoni e Frederico Coelho. Foi através de um texto sugerido pelo Fred, em que Jean Genet comenta sua aproximação com o artista plástico Giacometti, que entendi a relação da solidão com as artes: "Quem nunca ficou maravilhado com essa solidão, não conhecerá a beleza da pintura". E o que dizer dos estudos de literatura $e$ mercado propostos por Vera Follain, que trouxe debates como o das regras da arte e o da partilha do sensivel, baseando-se em Pierre Bordieau e em Jacques Ranciére, respectivamente, chegando a abordar a função da televisão discutida por Maria Rita Kehl? A questão que escolhi responder quando fiz a prova de seleção foi sobre a recepção e, lendo os alemães Hans Robert Jauss e Wolfgang Iser, antes mesmo de ser aprovada, eu já imaginava que estudar você seria incrível. Eu só pensava em sua plateia, na reação das pessoas quando te veem, o que passei a chamar de "recepção". Nas aulas de Júlio e nas conversas com ele, percebi a presença dos afetos em minha pesquisa e discuti muito sobre as histórias mal contadas já eternizadas e as formuladas para nos fazer refletir. Sim, há teóricos que, para estudar o fenômeno, fazem questão de criá-las para tentar 
explicá-las. É o caso de Silviano Santiago, que escreveu um liuro chamado "Histórias mal contadas". A nossa, Zé, é só uma delas.

Você me conheceu. Primeiro, impressionou-se com o meu conhecimento sobre sua obra. Depois, percebeu que, mesmo muito mais jovem e vinda de um ambiente completamente diferente do seu, eu tinha referências musicais e literárias muito parecidas com as suas. Você me deu a autorização para a produção da biografia, entregou-me material impresso e em forma de vídeo, topou algumas entrevistas por telefone e me convidou para alguns encontros. Mas me faltam mais encontros com você. E me faltam alguns dos artigos que sei que mantém trancados em seu arquivo. Deixar eu te desnudar em sua rotina de trabalho te parece demais, né? Só agora, depois de cinco anos, passei a desconfiar de que, naquele episódio em que tentei ir a Brejo do Cruz para ver seu terceiro show na sua cidade natal, em 2008, quem disse "não" foi você. E eu cheguei a me indispor com seu empresário, acreditando ser ele quem estava me impedindo de viajar com a equipe. Ou será que também não foi você? Na época, cada um me deu uma explicação diferente, o que me fez ficar sem resposta. Olha aí um exemplo de que não existe uma "verdade", mas diversas "realidades" em uma narração! Tinham me falado que você é um cara estranho, mas cada vez mais eu acredito que a questão não é pessoal, nada contra mim. Elba me contou que fazer aquele show com você na terceira edição do Rock in Rio, em janeiro de 2001, foi maravilhoso, mas que não havia a menor condição de aquela parceria virar um projeto. Ela disse que se desentendeu muito com Alceu e com você durante "O grande encontro", mas que nunca quis levar mágoa adiante, tanto que te convidou para fazer uma participação em um DVD que gravou no Marco Zero de Recife, em 2010, e ficou feliz por você ter aceitado e feito um número lindo ao lado dela. Elba desabafou que sofre com a sua distância, pois te adora. Falei para ela: "Mas esse é o Zé Ramalho e ele não é assim só com você!"

O que me parece complicado é não ter ainda sua versão de algumas histórias. Vou te dar um exemplo. Você comenta por aí que a canção "Garoto de aluguel (Taxi Boy)" é autobiográfica porque fala da época em que você trabalhou como garoto de programa para 
conseguir se sustentar no Rio de Janeiro, antes da gravação de seu primeiro disco. Passei anos acreditando que você trocava dinheiro por sexo. Recentemente, entrevistei uma senhora que contou ter vivido uma espécie de romance baseado em sexo com você naquela mesma época e confessou ter te ajudado financeiramente já que ela, por ser herdeira de um famoso escritor e por já ter uma carreira consolidada, era rica. Forcei a barra, perguntando se a senhora pagava a cada encontro com você e ela foi enfática: "Se ele fosse garoto de programa, tinha tudo para me envolver nessa, porque eu estava com grana. Um dia, eu falei: 'Estou doida para fumar um.' Zee podia ter se aproveitado e feito uma proposta, mas ele falou que tinha maconha na casa dele e me levou para lá. O que rolou foi uma transa maravilhosa. Depois, saímos por mais ou menos um mês e meio e eu emprestei uma grana para ele. Não virou namoro porque Zé Ramalho tinha uma coisa de ser o patriarca e eu não queria outra familia, pois tinha acabado de me separar, de sair de uma relação traumática. Cansei de homem naquela fase. Depois, eu fui namorar a Cátia de França, que era minha amiga e tocou na banda do Ze." Fora ela, não encontrei ninguém que confirmasse essa sua história. E agora, como vou saber se você foi mesmo garoto de aluguel ou se romanceou esse episódio após, por orgulho ou machismo, interpretar que receber dinheiro de mulher era se vender?

Outra questão é o seu pedido para que retire informações não só do livro do Henri Koliver como de outras entrevistas suas, como a que deu a Elinaldo Rodrigues para 0 documentário. Confiar em qualquer "conteúdo" não tem sido tarefa fácil para mim depois que passei a compreender que não existem verdades nas histórias que ando coletando, através das entrevistas que venho fazendo para o livro. Otha que engraçada essa declaração que Alceu Valença deu durante um papo nosso: "Enquanto eu via a história de uma maneira, Zé via de outra. Uma vez, a gente foi com nossos violões à chácara de Mickey e lone, em Recife. Eles que eram primos das nossas namoradas. Zé Ramalho lembra de quando nós invadíamos a chácara naquela noite de céu estrelado para fazer desafios maravilhosos. Para mim, foi simplesmente a gente saindo de dentro do carro e tocando." Muito interessante pensar sob este prisma, né? Imagine se eu acreditasse de primeira em qualquer história que me contam? O livro estaria pronto, porém cheio 
de deficiências. Creio, inclusive, que deficiências este que escrevo também terá, mas certamente muito menos, afinal, com essa demora em se resolver quando e como publicarei sua biografia, acabei aprendendo muito e mudando muito meu ponto de vista e meu formato de trabalho. Acredito que chegarei muito mais perto de uma história que vale a pena ser contada do que de uma trama criada para agradar a você, a sua familia, a algum parceiro ou aos leitores. Acho que o livro vai agradar por ser honesto. E eu vou cumprir meu objetivo, o mesmo de Mário de Andrade, que é "viver minha vida e ser louvado por mim nas noites antes de dormir."

Aí você me diz que eu deveria seguir o exemplo deste rapaz, o Henri, mas se esquece de que ele teve a chance de fazer todas as entrevistas presenciais que quis, porque você, na época, ainda não tinha tomado essa decisão de não dar mais entrevistas por estar cansado disso depois de tantos anos de carreira. No meu caso, sei que fizemos um trato quando me deste a autorização: tão logo eu assinasse o contrato com a editora, iniciaríamos a bateria de entrevistas. Mas, com a configuração mudando e eu começando a pesquisa de forma independente, sem o apoio de uma companhia editorial, você também foi preferindo falar comigo mais por telefone e, agora, por e-mail. Convenhamos que isso torna o meu trabalho muito mais difícil. Mas não desistirei: em breve, enviarei e-mails com as questões que preciso esclarecer ou desmistificar e rezarei para que sejas o mais honesto possível em suas respostas.

Hoje, Zé, escrevo essa carta - manuscrita como as primeiras que enviei - para te dar parabéns pelos 65 anos vividos. E para dizer que ainda estou na expectativa de publicar a sua biografia no ano que vem, de preferência, comemorando suas quatro décadas de carreira. Apesar de você renegar o "Paêbirú", esse é o primeiro disco seu e, portanto, o primeiro registro histórico de sua música. E ele saiu em 1975. Em 2015, teremos uma data redonda, né?

Um abraço,

C.F. 


\section{O sonho}

Niterói, 03 de outubro de 2015.

$2 \hat{e}$,

Você perdeu a festa de lançamento do livro e a comemoração do seu aniversário! Todo

mundo estava lá. Alceu, Elba e Geraldo. Fagner e Belchior vieram do Ceará, e Vital, Pedro, Onaldo, Stucker e Huguinho, da Paraiba. Cátia, Lizzie e Mazinho se reencontraram e lembraram os velhos tempos de banda. Oswaldo, Mautner, Macalé, Vandré, Baleiro e Zélia me surpreenderam ao aparecerem. E Caetano, Gil, Djavan e Chico? Nunca imaginei... Também não esperava por Paulo, Raul e Kika nem por Lula, que se esbaldou ao encontrar Paulo Rafael, Zé da Flauta e Lailson. OHo e Ernst, eu sabia que iam, assim como Tia Zelia, Thelma e seus filhos todos. Ísis, Amelinha e Roberta, bem como Adilson e Marco não podiam faltar. Meus amigos todos (Hérica, Gabito, Rod, Roni, Flávio, End, Erika, Taís e outros) e todos da sua banda me fizeram muito feliz com suas presenças. Jamari, Nêumanne, Osias, Mauro, Leandro e vários outros jornalistas cumpriram o nosso papel. O Professor Astromar apareceu depois da meia-noite e Bruno Mezenga, que deve ter acordado com as galinhas, foi o primeiro a chegar, acompanhado da sem-terra Luana. Lindo foi ver nossas mães, Estelita e Cristina, batendo o maior papo. Nossos irmãos, Goretti e Felipe, seus avós maternos, Simplício e Cristina, e os meus, Francisco e Moema, adoraram a festa. As avós paternas, Soledade e Orita, também foram nos prestigiar, assim como, acredite, José e Antônio (seu avô e seu pai) e Cornélio e Cornelinho (meu avô e meu pai). 
A festa estava linda... Optei por fazê-la ontem, dia 2 de outubro, para aproveitar que você ainda tinha 65 anos. Eu sabia que os jornalistas que convidei iam adorar a data redonda. Eles já chegaram lá com seus caderninhos nas mãos porque sabiam da efeméride: os 40 anos do lançamento do "Paêbirú". Nas entrevistas, eu disse que havia tentado publicar sua biografia quando você tinha 60, mas que só foi possivel cinco anos depois. Depois de falar isso, achei tudo meio cabalístico. 0 cinco aparece em 1975 e em 2015, por isso achei que me daria sorte esse lançamento acontecer justamente nesse momento em que eu acabei de completar 35 anos e você ainda está com 65. Meu pai só vai alcançar sua idade em janeiro de 2016 e eu morria de medo de ele não chegar lá, afinal, tanto meu avô paterno quanto o materno morreram aos 65. Mas, sabe, Zé, acho que, se você chegou até aqui com essa saúde de quem vai bem mais longe, tenho certeza de que meu pai também viverá muito. Fora isso, parece-me que ele puxou à Dona Orita, como eu acho que puxei também. Se assim for, chegaremos aos 100 que ela completou em julho.

Foi numa livraria do Leblon. A luz estava mais fraca, o que deixou o clima soturno. Tudo a ver com a gente! $E$ tinha uns garçons servindo bebidas e aperitivos. Eu autografei muitos livros e posei para fotos com vários fãs seus. É engraçado como eles transferem a admiração, né? Eu juro que não esperava por isso e confesso que nem me sinto muito à vontade. Parafraseando Mário de Andrade em uma das cartas que escreveu a Manuel Bandeira, "eu já disse pra você que vivo gostando, não vivo pra ser célebre". Gosto mesmo é de tirar fotos com pessoas que admiro. Pedi ao fotógrafo para não deixar de registrar meus encontros com os convidados que citei aí em cima. Em um certo momento, eu e meu pai fomos chamados ao palco por Chico César, paraibano como você e secretário de Cultura do Estado entre 2010 e 2014. Ele foi um dos entrevistados para o livro e me contou que, quando adolescente, muito baixinho, assistiu ao primeiro show que você fez em Brejo do Cruz de cima de uma árvore algaroba. Admirador do conterrâneo e ótimo discursista depois dessa experiência na política, ele aceitou ser o mestre de cerimônia da festa. Com meu pai ao violão e nos vocais e comigo acompanhando naquele violão que o luthier paraibano Carlos Pau Brasil produziu a partir de um desenho de Geraldo Azevedo e te enviou - e 
você pediu que eu guardasse comigo até você abrir espaço em sua casa para mais um instrumento -, cantei cinco canções de sua carreira que marcaram demais minhas pesquisas: "Mistérios da meia-noite", "Chão de giz", "Admirável gado novo", "Tá tudo mudando" e, para terminar, "Avôhai".

Comentei sobre essa passagem que Chico me contou porque não sei até agora se você leu o livro. Como diria Graciliano Ramos, "falemos intelectualmente; falaremos depois coracionalmente." Faz cinco meses que te mandei os originais e fiquei aguardando possiveis alterações. Roberta me ajudou muito revisando o texto e corrigindo informações que não estavam corretas. Gostei muito da maneira como ela acatou pedidos que fiz para que mantivéssemos trechos que, a princípio, pareciam-the muito delicados. Imagino que essa generosidade veio de você também. Agradeço por cumprir sua parte no trato que fizemos em 2007, no qual estava combinado que meu papel era escrever uma biografia autorizada, porém não chapa branca. Diferentemente do que passaram as biógrafas de Sylvia Plath, você não pegou a caneta para reescrever a história. Durante todo o processo, fiquei imaginando se Roberta atuaria como Olwyn, a irmã de Ted Hughes, que, segundo Janet Malcom, "não afrouxou suas garras de ferro", obrigando uma das escritoras "a recuar, a ceder, a desistir de algumas coisas que pensara em usar, a incluir coisas que preferia deixar de fora." Não foi o que aconteceu. No final desse processo, $2 \dot{e}$, dei-me conta de que eu nunca seria um arrombador profissional, como Janet Malcolm designa os biógrafos, afinal, em um país como o Brasil, eu não me arriscaria a fazer uma biografia não autorizada, apesar de ser a favor da publicação do Projeto de Lei. Como Malcolm, acredito que "ninguém é dono dos fatos de sua vida". Fora isso, qualquer incomodado poderia acionar a Justiça por calúnia, porque é óbvio que, mesmo sem autorização, para escrever uma boa biografia, o escritor precisa ter documentos que provem o que ele está publicando: certidões, material jornalistico, entrevistas com as fontes... Eu preferi ganhar a confiança de vocês todos para fazer o livro que eu queria. $E$, apesar dos nossos momentos de desavenças, eu o fiz.

Sabe de uma coisa? Janet insiste o tempo todo em mostrar que ela deu o máximo de si para provar os fatos da trajetória de Sylvia, mas eu desconfio que ela desistiu de produzir uma 
biografia tradicional porque viu que nunca conseguiria contar uma história verdadeira. Sendo assim, deve ter sido muito mais fácil fazer uma crítica biográfica, comentando outros livros e ponderando as próprias descobertas. Eu fiz o mesmo que ela, entrevistando essa quantidade de gente, buscando documentos, confirmando narrações com você, com Roberta e com outras fontes, mas concluí que grande parte dos episódios narrados aí tem uma porcentagem de ficção. Não falo de nomes, datas, certidões ou boletins, porque esses documentos, eu os tenho em papel. E, graças a Deus, ninguém os destruiu como fez Ted Hughes com as páginas do diário da ex-mulher. Falo dos "causos", dos episódios narrados a mim. Fora isso, Zé, há a minha interpretação de alguns fatos, né? Eu precisei te acompanhar por 15 anos, de longe e de perto, para criar o meu personagem. Como a jornalista americana, eu também tentei me aproximar ao máximo, em sua descrição, do que você é. É claro que ouvir opiniões dos outros me ajudou a entender melhor sua personalidade, mas aposto que, para Roberta, você é um homem e, para Ísis ou Amelinha, é outro completamente diferente.O fato é que escrevi o livro e, na introdução, usei parte da minha dissertação do mestrado para avisar ao leitor que nem pelas minhas mãos nem pelas de outro escritor ele poderá ter uma biografia definitiva de Zé Ramalho, simplesmente porque a palaura "definitiva" não define o que a maioria dos leitores pensa.

Por falar nas mulheres de sua vida, uma das maiores dificuldades que tive não foi entender o que aconteceu entre você e Lula Côrtes nem o que rolou em "O grande encontro". Para mim, o maior desafio foi traçar seu perfil como marido. Baseando-me em alguns depoimentos de pessoas que conviveram com você e suas três esposas, vivi momentos de tensão até descobrir a sua faceta pai de familia. Primeiro, achei que você era um homem submisso, afinal, muitos diziam que Ísis não era uma pessoa fácil e que você vivia tentando se adequar à relação. Sua prima caçula, Thelma Ramalho, me contou que a saia mais curta que ela viu na vida foi a de Ísis e que ela se impressionou no dia em que, com raiva depois de alguma briga, sua mulher cortou o cabelo, fez mechas e permanente. Mesmo assim, você continuou com ela. Fiquei confusa quando Thelma disse que, apesar de Ísis ser uma mulher muito "avançada" para a época, ela se casou com você na 
Igreja, em um vestido de noiva lindo. Pelo pouco que sei sobre transgressão, parece-me que saia curta e vestido de noiva, naquela época, não combinavam. Falando de Amelinha, passei a achar que você era um cara machista, chegando até a ser meio agressivo em alguns momentos. Essa conclusão tirei depois que algumas pessoas do convivio do casal comentaram que, ciumento, quando brigava com ela, você jogava coisas na parede. Mas a própria Amelinha me contou que havia um romance lindo e que, em um certo momento, os desentendimentos passaram a ter mais espaço do que o amor nessa relação. Uma das minhas fontes comentou que você se incomodava com o fato de ela não ser aquele modelo de esposa que cuida da casa e da familia. Foi mais ou menos aí que liguei os fatos, não sem antes fazer a minha entrevista com Roberta Fontenelle, que virou Roberta Ramalho.

São 31 anos de união, sendo que ela perdeu um tempão tentando te resgatar do fundo do poço no qual você estava para te ensinar a viver novamente. E, assim como Keith Richards diz em sua autobiografia que "o estilo rebelde é algo que você constrói", acredito que também é possivel deixar esse estilo de lado para assumir a postura de homem maduro, coisa que fez depois dessa convivência. Percebo que você e Roberta viraram uma força só, principalmente quando você se deu conta de que ela seria a mulher que reorganizaria a sua vida. Roberta me contou que, em 1984, quando ela chegou ao Rio, você tinha acabado de se separar e ficava doido de saudades dos filhos, João e Maria, que via pouco porque Amelinha andava muito fora de casa por causa dos shows que fazia. Roberta veio para tentar regularizar a documentação de um carro que tinha ganhado de Amelinha, mas que estava no nome dela. Chegando no apart hotel onde a prima famosa morava, levou um fora e acabou precisando arrumar um lugar para se hospedar. Acompanhada do irmão, por acaso atendeu a uma ligação sua através da qual você pedia para ver seus filhos. Sabendo do acontecido, você acabou convidando a dupla para ficar em sua casa. Fora a pessoal, ela também percebeu a bagunça profissional na qual você estava: além de afastado do showbusiness, devia dinheiro à gravadora e não tinha controle nenhum dos seus ganhos e gastos. Essa cearense arretada, que largou a faculdade de Engenharia em Fortaleza para ficar com você, 
conseguiu organizar tudo isso, cuidar de você durante o período de abstinência e ainda ser sua maior companheira nos momentos em que voltou a conseguir reunir seus filhos e, ainda, ter mais dois com ela. Roberta voltou à faculdade, para estudar Direito, e assumiu a tarefa de administrar sua vida e obra. Entendi de uma vez por todas que o que você sempre quis, na verdade, era ter uma familia estruturada, com uma mulher forte o suficiente para estar por trás desse grande homem que hoje você é. Está comprovada a máxima que diz que atrás de um grande homem tem uma grande mulher. O que achei o máximo foi comprovar que você, apesar de parecer durão, é um romântico inveterado. Não foi à toa que a Giza, a tal mulher casada com quem viveu um breve romance ainda jovem, na Paraíba, foi homenageada na canção "Chão de giz". Não foi à toa que você entregou uma foto linda sua, com uma poesia manuscrita no verso, para Glauce Botelho, sua namorada e irmã de Ângela, a namorada de Alceu de Recife. Eu vi essa foto, sabia?

Em todos esses anos de pouca proximidade e pouca convivência, mas de constante presença minha nas suas vidas e de vocês na minha, acostumei-me a falar com Roberta como se estivesse falando com você e vice-versa. Como retribuição por tudo o que ela fez, você confiou a esta mulher toda a sua vida e obra, estas que foram confiadas a mim quando decidiu me dar aquela autorização. Com os encontros que tive com Roberta, não me senti mais obrigada a esperar por um retorno seu. Tenho quase certeza de que, se ela leu e aprovou, é porque você também gostou. Também, Zé, confesso que me importo menos hoje com o que os outros vão pensar ou falar do que já me importei um dia. Você já me disse que, na vida, fazemos ficção porque a verdade não costuma agradar as pessoas. Então, se minha verdade não agradar a qualquer um, que encarem meu liuro como uma ficção.

Zé, apesar de eu ter conseguido um final feliz, despeço-me desta história certa de que cumpri minha missão, aquela que dei a mim mesma ainda muito jovem, sem saber os caminhos que minha vida ia tomar. Muita coisa mudou, mas uma delas, não. Nunca esperei ficar famosa às suas custas. Eu sempre soube que biografias não são os liuros mais vendidos no Brasil. Reconhecimento profissional, já o tive em vários momentos e acredito que agora o vá ter 
novamente. São sensações fugazes essas sentidas durante os 15 minutos de fama que temos quando assinamos embaixo de algum feito. Aprendi a não me deslumbrar, principalmente porque elas só duram os 15 minutos comentados por Andy Wharol. Nada disso importa. Eu escrevo por prazer, por amar contar histórias e porque, assim como Caio Fernando Abreu, quero que alguém me ame por algo que escrevi (ou ainda vou escrever). Vou de novo parafrasear Mário: "Tenho um poder de festas, de convites, de amizades, passeios que satisfaço religiosamente. Não dou prá celebridade e eternização do meu nome a mínima importância. Não tenho nenhuma vaidade nêsse sentido. Se escrevo é primeiro porque amo os homens. Tudo vem disso pra mim. Amo e por isso é que sinto esta vontade de escrever, me importo com os casos dos homens, me importo com os problemas dêles e necessidades. Depois escrevo por necessidade pessoal. (...) Mas mesmo isto psicológicamente ainda pode ser reduzido a um fenômeno de amor, porquê ninguém escreve para si mesmo a não ser um monstro de orgulho. A gente escreve para ser amado, pra atrair, encantar, etc." Continuo esperando que você me ame, de alguma forma, pela sua história que escrevi.

E sigo à disposição para novas parcerias profissionais. Posso dizer que, apesar da ausência, você foi um dos melhores parceiros que tive. E tenho certeza que fui uma das poucas jornalistas - senão a única - que conseguiu não se afastar de você.

Beijos da sua biógrafa! 


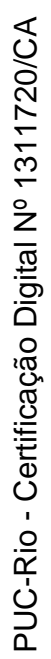

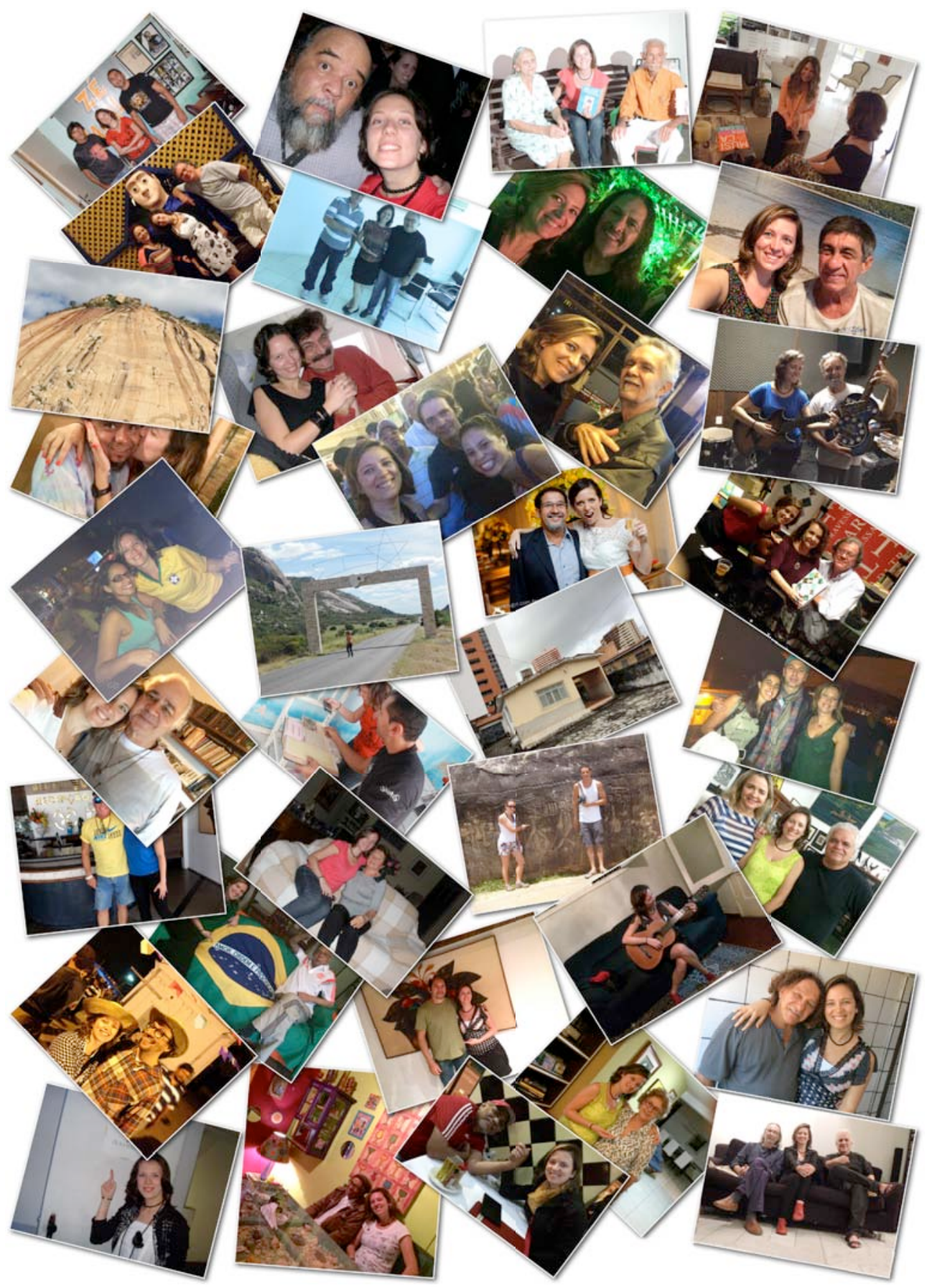


Conclusão

\section{Conclusão}

Rio de Janeiro, 20 de março de 2015.

Olá, Júlio! Tudo bem?

Enfim, a dissertação! Que não é a biografia. Depois de tanto me entender e desentender com 0 gênero literário, por fim, escrevi uma autobiografia. Passei 14 anos investigando a vida e a obra Ze Ramalho, mas foram precisos mais esses dois anos lendo Michael Foucault, Jacques Derrida, Jean-Luc Nancy, Caio Fernando Abreu, Janet Malcolm, Silviano Santiago, Mário de Andrade, Graciliano Ramos e tantos outros para eu me dar conta de que, para produzir o livro que tanto sonhei, eu precisaria articular muitas questões em torno de certas discussões, expostas nesse trabahtho que você acabou de ler.

Foi essa sensação de incompreensão de diversos episódios e/ou aspectos da biografia de Zé Ramalho o que me motivou a escrever cartas a ele e a outros personagens com os quais ele teve ou tem algum envolvimento em sua vida pessoal e profissional. $A$ ausência de respostas ou respostas que não superaram minhas expectativas me levaram a querer fazer uma crítica biográfica não só da trajetória de Zé Ramalho como também das declarações colhidas por mim durante minhas entrevistas com seus parentes, amigos e parceiros e dos livros e filmes já publicados sobre 0 artista. Fora isso, eu ainda precisei analisar e tentar retirar as pedras colocadas no meu caminho pelos editores que não acreditaram em meu projeto e, também, pelo próprio Zée.

Uma questão que tentei explorar nas cartas que escrevi e nas que recebi são as marcas biográficas nas canções, nas relações pessoais e profissionais de Ze Ramalho e nas 
decisões tomadas pelo artista ao longo de sua trajetória. Também procurei examinar as biografias já existentes sobre ele, confrontando umas com as outras e com a minha própria pesquisa. Concluí que os sujeitos das experiências, assim como os observadores, percebem as ações ou situações próprias e alheias por prismas diferentes. Inclusive eu.

Como meu orientador, você me ajudou a entender, entre outras coisas, que as cartas de Mário e de Graciliano são importantes documentos históricos, que fornecem informações biográficas não compiladas em uma biografia única desses escritores. Você praticamente atuou como meu editor durante esse período em que percebi que as correspondências que enviei a Zé, as que não enviei, as que escrevi para outros personagens e as que não recebi de parceiros e parentes do meu biografado também contam uma história que envolve não somente ele e as pessoas com as quais se relacionou ao longo da vida, como a mim.

Diante dessa percepção e com sua ajuda e incentivo, decidi colocar-me como observadora de segunda ordem da trajetória de Zé Ramalho. Em um certo momento de minha pesquisa, desisti de buscar verdades porque comecei a encontrar realidades discursivas narradas por Zé e pelos personagens tanto nas matérias publicadas em jornais e revistas quanto nos registros em liuros e nas minhas entrevistas. Muitas beiravam a ficção, gênero que até eu precisei utilizar para conseguir entrelaçar todas as histórias contadas.

Acredito que este trabalho tenha resultado em uma análise sobre a relação entre mim como biógrafa e ele como biografado e, assim, numa discussão esclarecedora dos procedimentos intelectuais e sensitivo-afetivos envolvidos na produção desse gênero. Dessa forma, espero estar contribuindo para a desmistificação da noção de verdade única e critério estético preestabelecidos, para a valorização da presença do artista em sua obra e para uma reconfiguração da avaliação crítica operada pela subjetividade contemporânea.

Um beijo,

Christina (ou, se preferir, Christininha ou Chris) 


\section{Bibliografia}

AGAMBEN, Giorgio. O que é o contemporâneo? E outros ensaios. Chapecó: Argos Editora da Unochapecó, 2009.

ALVEZ, Luciane. Zé Ramalho: Um visionário no Século XX. Nova Era: Rio de Janeiro, 1997.

ANDRADE, Carlos Drummond. Poesia Completa. Rio de Janeiro: Editora Nova Aguilar, 2002, pág. 617.

ANDRADE, Mário. Cartas a Manuel Bandeira. Rio de Janeiro: Ediouro, 1967.

A lição do amigo. Org.: Carlos Drummond de Andrade. Rio de Janeiro: José Olympio, 1982.

Cartas a Anita Malfatti. Org.: Marta Rossetti Batista. Rio de Janeiro: Forense Universitária, 1989.

ARAÚJO, Paulo César de. Roberto Carlos em detalhes. São Paulo: Planeta, 2007.

O réu e o rei. São Paulo: Companhia das Letras, 2014.

ARFUCH, Leonor. $O$ espaço biográfico: Dilemas da subjetividade contemporânea. Rio de Janeiro: EdUerj, 2010.

ARISTÓTELES. Arte Retórica e Arte Poética. Tradução de Antônio Pinto de Carvalho. Ediouro: Rio de Janeiro, s/d.

AZEVEDO, Aluísio. O cortiço. São Paulo, L\&PM Pocket, 1998.

BAHIANA, Ana Maria. Almanaque anos 70. Rio de Janeiro: Ediouro, 2006.

BAUMAN, Zygmunt. O mal-estar da Pós-Modernidade. Rio de Janeiro: Jorge Zahar, 1998.

. Modernidade Líquida. Rio de Janeiro: Jorge Zahar, 2001. 
Identidade. Rio de Janeiro: Jorge Zahar, 2005.

BERGER, Peter L. Alternação e biografia ou: como adquirir um passado préfabricado. In: Perspectivas sociológicas. Rio de Janeiro: Vozes, 1983, p 65-77.

BORDIEAU, Pierre. As regras da arte. São Paulo: Companhia das Letras, 1996.

CALADO, Carlos. A divina comédia dos Mutantes. Rio de Janeiro: Editora 34, 1995 . . Tropicália - A história de uma revolução musical. São Paulo: Editora 34, 1997.

CAMÕES, Luís. Os Lusíadas. Ateliê Editorial, 6a edição: Cotia, 2012.

CUNHA, Euclides. Os sertões. São Paulo, Ática, 2009.

DAPIEVE, Arthur. Brock - o Rock Brasileiro dos Anos 80. Rio de Janeiro: Editora 34, 1995.

DELEUZE, Gilles e Felix Guattari. Percepto, afecto, conceito. In: O que é filosofia? Rio de Janeiro: Ed.34, 1992, p.211-255.

DERRIDA, Jacques. Mal de arquivo - Uma impressão Freudiana. Rio de Janeiro: Relume Dumará, 2001.

DINIZ, Júlio Cesar Valladão. Literatura em translação. In: Leituras sobre música popular. Rio de Janeiro: 7 Letras, 2008.

Música Popular: Leituras Desleituras. In: Literatura e Mídia. Editora PUCRio: São Paulo, 2002.

DIP, Paula. Para Sempre Teu, Caio F. Rio de Janeiro: Editorial Record, 2009.

DOUBROVSKY, Serge. Autobiographiques. Paris: Presses Universitaires, 1988.

EDNARDO. Massafeira 30 anos. São Paulo: Aura Edições, 2010.

FOUCAULT, Michel. A ordem do discurso. São Paulo: Edições Loyola, 2012. A Hermenêutica do Sujeito. São Paulo: Martins Fontes, 2004. 
A escrita de si. In: Ditos e escritos $\mathrm{V}$ - ética, sexualidade, política. 3 Ed. Rio de Janeiro: Forense, 2012.

FRANÇA, Jamari. Os Paralamas do Sucesso - Vamo Batê Lata. São Paulo: Editora 34, 2003.

FRÓES, Marcelo. Jovem Guarda - Em ritmo de aventura. São Paulo: Editora 34, 2000.

GALEANO, Eduardo. Las palabras andantes. Buenos Aires, Siglo Veintiuno Editores, 2013.

GALLE, Helmut. Elementos para uma nova abordagem da escritura autobiográfica. In: Matraga (Rio de Janeiro), v. 18, p. 64-91, 2006.

GARRAMUÑO, Florencia. Frutos estranhos. Rio de Janeiro: Rocco, 2014.

GENET, Jean. O atelier de Giacometti. São Paulo: Cosac Naify, 2000.

GIORDANO, Alberto. Una possibilidad de vida. Rosario: Beatriz Viterbo Editora, 2006.

GONZÁLEZ, Juan Pablo. Pensar la música desde América Latina. Buenos Aires: Gourmet Musical Ediciones, 2013.

HALL, Stuart. Estudos culturais e seu legado teórico. In: HALL, Stuart. Da diáspora: identidades e mediações culturais. Belo Horizonte: Editora UFMG, 2003.

A identidade cultural na pós-modernidade. Rio de Janeiro: DP\&A Editora, 2006.

HORROCKS E JEVTIC, Chris e Zoran. Entendendo Foucault - Um guia ilustrado. São Paulo: Leya, 2013.

HUXLEY, Aldous. Admirável mundo movo. São Paulo: Abril Cultural, 1982.

KEHL, Maria Rita. Um só povo, uma só cabeça, uma só nação. In: NOVAES, Adauto. Anos 70 ainda sob a tempestade. Rio de Janeiro: Senac RJ, 2005.

KOLIVER, Henri. Zé Ramalho, o poeta dos abismos. Aldeia Editorial: São Paulo, 2008. 
LEJEUNE, Philippe. O pacto autobiográfico. De Rousseau à internet. Belo Horizonte: UFMG, 2008.

LIMA, Luiz Costa (org.) A Literatura e o Leitor. Textos de estética da Recepção. Rio de Janeiro: Paz e Terra, 2002.

LITTAU, Karin. El papel de los afectos en la crítica literária. In: Teorías de la lectura. Libros, cuerpos y bibliomania. Buenos Aires: Manantial, 2008, p.135-162. MALCOLM, Janet. A mulher calada - Sylvia Plath, Ted Hughes e os limites da biografia. São Paulo: Companhia das Letras, 1994.

MARMO, Hérica. A canção do mago. São Paulo: Futuro, 2007.

MARMO e ALZER, Hérica e Luiz André. Titãs - $A$ vida até parece uma festa. Rio de Janeiro: Editorial Record, 2002.

MAUTNER, Jorge. Filho do Holocausto. Rio de Janeiro: Agir, 2006.

MIRANDA, Wander Melo. Corpos escritos Graciliano Ramos e Silviano Santiago. São Paulo: Belo Horizonte: Editora UFMG, 1992.

MOTTA, Nelson. Noites Tropicais - Solos, improvisos e memórias musicais. Rio de Janeiro: Objetiva, 2000.

NANCY, Jean-Luc. Archivida. Del sintiente y del sentido. Buenos Aires: Editorial Quadrata, 2013.

A la escucha. Buenos Airs, Amorrortu, 2007.

NIETZSCHE, Friedrich. O nascimento da tragédia ou helenismo e pessimismo. São Paulo: Companhia das Letras, 1992.

OLINTO, Heidrun Krieger. Autobiografias intelectuais entre razão e emoção. III Simpósio Discurso, Identidade e Sociedade. Dilemas e desafios na contemporaneidade. In: http://www.iel.unicamp.br/sidis/anais/pdf/OLINTO_HEIDRUN_KRIEGER.pdf. "Letras na página/Palavras no mundo". In: Palavra, 1, 1993. p. 7-40.

RAMALHO, Zé. MPBook. Rio de Janeiro: Gryphus, 1998. 
Apocalypse. Fortaleza: Antologia llustrada dos Cantadores, 1975.

RAMOS, Graciliano. Cartas. Rio de Janeiro: Record, 2011. Memórias do cárcere. Rio de Janeiro: Record, 1996. 2v.

RANCIÈRE, Jacques. A partilha do sensível: estética e política. São Paulo: Ed. 34, 2009.

RESENDE, Beatriz. Apontamentos de crítica cultural. Aeroplano Editora: Rio de Janeiro, 2002.

RICHARDS, Keith. Vida. São Paulo: Editora Globo, 2010.

RISÉRIO, Antonio. Caymmi: Uma utopia de lugar. São Paulo: Perspectiva, 2011.

SALEM, Tatiana Levy. A chave de casa. Rio de Janeiro: Record, 2007.

SANTIAGO, Silviano. Histórias mal contadas. Rio de Janeiro: Rocco, 2005. O falso mentiroso. Rio de Janeiro: Rocco, 2004. Em liberdade. Rio de Janeiro: Rocco, 2013.

SLATER, Candace. A vida no barbante: a literatura de cordel no Brasil. Trad.: Octávio Alves Filho. Rio de Janeiro: Civilização brasileira, 1984.

SILVA, Gonçalo Ferreira. Vertentes e evolução da literatura de cordel. Rio de Janeiro: Editora Milart, 2005.

SONTAG, Susan. Contra a interpretação. Porto Alegre: L\&PM, 1987, p.318-337.

SOUZA, Eneida Maria de. Crítica Cult. Belo Horizonte: Editora UFMG, 2002.

TATIT, Luiz Augusto de Moraes. Semiótica da canção - Melodia e letra. São Paulo: Escuta 1994.

TELES, José. Do frevo ao manguebeat. Editora 34: São Paulo, 2000.

VENTURA, Zuenir. 1968 - O ano que não terminou. A aventura de uma geração. Rio de Janeiro: Editora Nova Fronteira, 1988. 
VERSIANI, Daniela. Um mapeamento inicial do paradigma construtivista. In: e Heidrun Krieger Olinto (orgs.). Cenários construtivistas: temas e problemas. Rio de Janeiro: 7Letras, 2010, p.43-57.

ZUMTHOR, Paul. Performance, recepção e leitura. São Paulo: Cosac Naify, 2007.

WISNIK, José Miguel. O som e o sentido: Uma outra história das músicas. Companhia das Letras: São Paulo, 1989. 


\section{Discografia}

LOBÃO. Vida Bandida. Rio de Janeiro: RCA Victor, 1987. 1 disco (35 min 41 seg.): 33 1/3 rpm, microssulco, estéreo.

RAMALHO, Zé. Zé Ramalho. Rio de Janeiro: CBS, 1978. 1 disco (33 min): 33 1/3 rpm, microssulco, estéreo.

RAMALHO, Zé. A peleja do diabo com o dono do céu. Rio de Janeiro: CBS, 1979. 1 disco (38 min): 33 1/3 rpm, microssulco, estéreo.

AZEVEDO, Geraldo. RAMALHO, Elba. RAMALHO, Zé. VALENÇA, Alceu. O grande encontro. São Paulo: BMG, 1996. 1 disco compacto (46 min.): digital, estéreo.

AZEVEDO, Geraldo. RAMALHO, Elba. RAMALHO, Zé. O grande encontro 2. São Paulo: BMG, 1997. 1 disco compacto (48 min.): digital, estéreo.

AZEVEDO, Geraldo. RAMALHO, Elba. RAMALHO, Zé. O grande encontro 3. São Paulo: BMG, 1998. 1 disco compacto (48 min.): digital, estéreo.

RAMALHO, Zé. Eu sou todos nós. Manaus: BMG, 1998. 1 disco compacto (39 min.): digital, estéreo.

RAMALHO, Zé. Estação Brasil. Manaus: BMG, 2003. 2 discos compactos (78 min.): digital, estéreo.

RAMALHO, Zé. Antologia Acústica. Rio de Janeiro: BMG, 1997. 2 discos compactos (84 min. 36 seg.): digital, estéreo.

RAMALHO, Zé. Nação nordestina. Rio de Janeiro: BMG, 2000. 2 discos compactos (81 min. 18 seg.): digital, estéreo.

VELOSO, Caetano. Cê. Rio de Janeiro: Universal, 2006. 1 disco compacto (45 + min.): digital, estéreo. 
RAMALHO, Zé. CD e DVD Parceria dos viajantes. Manaus: Sony\&BMG, 2007. 1 disco compacto (45 min.): digital, estéreo. + 1 DVD (68 min.)

RAMALHO, Zé. CD e DVD Tá Tudo mudando - Zé Ramalho canta Bob Dylan. Manaus: EMI, 2008. 1 disco compacto (48 min.): digital, estéreo. + 1 DVD (65 $\min$.)

RAMALHO, Zé. CD e DVD Ao vivo. São Paulo: Sony\&BMG, 2005. 1 disco compacto (44 min.): digital, estéreo. + 1 DVD (63 min.)

RAMALHO, Zé. A terceira lâmina. São Paulo: Epic, 1980. 1 disco (35 min. 15 seg.): 33 1/3 rpm, microssulco, estéreo.

RAMALHO, Zé. Orquídea negra. Rio de Janeiro: Epic, 1983. 1 disco (44 min. 32 seg.): 33 1/3 rpm, microssulco, estéreo.

RAMALHO, Zé. Por aquelas que foram bem amadas. São Paulo: Epic, 1984. 1 disco (34 min. 48 seg.): 33 1/3 rpm, microssulco, estéreo.

RAMALHO, Zé. De gosto de água e de amigos. Rio de Janeiro: Epic, 1984. 1 disco (44 min. 56 seg.): 33 1/3 rpm, microssulco, estéreo.

VALENÇA, Alceu; AZEVEDO, Geraldo. Quadrafônico. São Paulo: Copacabana, 1972. 1 disco (34 min. 03 seg.): 33 1/3 rpm, microssulco, estéreo.

VALENÇA, Alceu. Molhado de suor. Rio de Janeiro: Som Livre, 1974. 1 disco (30 min. 22 seg.): 33 1/3 rpm, microssulco, estéreo.

RAMALHO, Elba. Alegria. Rio de Janeiro: Polygram, 1982. 1 disco (35 min. 30 seg.): 33 1/3 rpm, microssulco, estéreo.

DYLAN, Bob. Bringing it all back home. New York City: Columbia, 1965. 1 disco (47 min. 14 seg.): 33 1/3 rpm, microssulco, estéreo.

DYLAN, Bob. Highway 61 revisited. New York City: Columbia, 1965. 1 disco (51 min. 26 seg.): 33 1/3 rpm, microssulco, estéreo.

BEATLES, The. Sgt. Pepper's Lonely Hearts Club Band. Londres: Parlophone, 1967. 1 disco (39 min. 42 seg.): 33 1/3 rpm, microssulco, estéreo. 
LEÃO, Hugo. Paraibô. Recife: HP, 1978. 1 disco (30 + min.): 33 1/3 rpm, microssulco, estéreo.

LEÃO, Hugo. Coração de Brasil. Rio de Janeiro: Epic, 1983. 1 disco (30 + min.): 33 1/3 rpm, microssulco, estéreo.

CAVALCANTI, Lailson de Holanda; CÔRTES, Lula. Satwa. Recife: Rozenblit, 1973. 1 disco $(30+\min ):$.33 1/3 rpm, microssulco, estéreo.

NOTARO, Marconi. No sub reino dos metazoários. Recife: Rozenblit, 1973. 1 disco $(30+\min ):$.33 1/3 rpm, microssulco, estéreo.

RAMALHO, Zé. Cidades e lendas. Rio de Janeiro: BMG, 1996. 1 disco (42 min. 16 seg.): digital, estéreo.

FAGNER, Raimundo; RAMALHO, Zé. DVD e CD Fagner \& Zé Ramalho ao vivo. Rio de Janeiro: Sony Music, 2014. 1 disco compacto (34 min.): digital, estéreo. 1 DVD (68 min.).

RAMALHO, Zé. Sinais dos tempos. Manaus: Avôhai Music, 2012. 1 disco compacto (49 min.): digital, estéreo.

FAGNER, Raimundo. Manera fru fru manera: O Último Pau-de-Arara. Rio de Janeiro: Philips, 1973. 1 disco (42 min. 24 seg.): 33 1/3 rpm, microssulco, estéreo.

RAMALHO, Zé. Zé Ramalho canta Raul Seixas. Rio de Janeiro: Globo Columbia, 2001. 1 disco (38 min. 50 seg.): digital, estéreo.

RAMALHO, Zé. Avôhai. In: Zé Ramalho. Rio de Janeiro: CBS, 1978. 1 disco sonoro. Lado A, faixa 1.

RAMALHO, Zé. Admirável gado novo. In: A Peleja do Diabo com o Dono do Céu. Rio de Janeiro: CBS, 1979. 1 disco sonoro. Lado A, faixa 2.

RAMALHO, Zé. Mistérios da meia-noite. In: Vários. Roque Santeiro. Rio de Janeiro: Sigia, 1985. 1 disco sonoro. Lado A, faixa 5.

RAMALHO, Zé. Chão de giz. In: Zé Ramalho. Rio de Janeiro: CBS, 1978. 1 disco sonoro. Lado A, faixa 3. 
VALENÇA, Alceu; RAMALHO, Zé. A dança das borboletas. In: RAMALHO, Zé. Zé Ramalho. Rio de Janeiro: CBS, 1978. 1 disco sonoro. Lado A, faixa 5.

RAMALHO, Zé. Beira-Mar. In: A Peleja do Diabo com o Dono do Céu. Rio de Janeiro: CBS, 1979. 1 disco sonoro. Lado A, faixa 5.

RAMALHO, Zé. Canção agalopada (com Maria Lúcia Godoy). In: A Terceira Lâmina. Rio de Janeiro: CBS, 1980. 1 disco sonoro. Lado A, faixa1.

RAMALHO, Zé. Águas de março (Part.: Tetê Espíndola) . In: . Estação Brasil. Rio de Janeiro: BMG, 2003. 2 CDs. CD 1, faixa 2.

RAMALHO, Zé. Frevo Mulher. In: AMELINHA. Frevo Mulher. Rio de Janeiro: CBS, 1979. 1 disco sonoro. Lado A, faixa 1.

RAMALHO, Zé. Mulher nova, bonita e carinhosa faz o homem gemer sem sentir dor. In: AMELINHA. Mulher Nova, Bonita e Carinhosa Faz o Homem Gemer Sem Sentir Dor. 1 disco sonoro. Rio de Janeiro: CBS, 1982. Lado A, faixa 1.

BLACK, Arnaldo; RENNÓ, Carlos. Escrito nas estrelas. In: ESPÍNDOLA, Tetê. Escrito nas Estrelas. São Paulo, Barclay/Polygram, 1985. 1 disco sonoro. Lado A, faixa 1.

TEIXEIRA, Renato. Romaria. (Part.: Fagner). In: RAMALHO, Zé. Estação Brasil. Rio de Janeiro: BMG, 2003. 2 CDs. CD 2, faixa 4.

LATINO. Festa no Apê (Dragostea Din Tei). In: As Aventuras de DJ L: Festa no Apê - Festa No Apê. Rio de Janeiro: EMI, 2004. 1 CD, faixa 1.

VELOSO, Caetano. Porquê? In: . Cê. Rio de Janeiro: Universal, 2006. 1 CD, faixa 10 .

VINNY. Heloísa, mexe a cadeira. In: Todomundo. Rio de Janeiro: Indie, 1997. 1 CD, faixa 1.

RAMALHO, Zé. Vila do Sossego. In: Zé Ramalho. Rio de Janeiro: CBS, 1978. 1 disco sonoro. Lado A, faixa 2.

FAGNER, Raimundo. Canteiros. In: Fagner. Manera Fru Fru Manera. Rio de Janeiro: CBS, 1973. 1 disco sonoro. Lado B, faixa 2. 
RAMALHO, Zé. Força verde. In: . Força Verde. Rio de Janeiro: CBS, 1982. 1 disco sonoro. Lado A, faixa 1.

RAMALHO, Zé. Jacarepaguá blues. In: Por Aquelas Que Foram Bem Amadas. Rio de Janeiro: CBS, 1984. 1 disco sonoro. Lado B, faixa 5.

DYLAN, Bob. Mr. tambourine man. In: Bringing It All Back Home. New York City: Columbia, 1965. 1 disco sonoro. Lado B, faixa 2.

DYLAN, Bob. Subterranean homesick blues. In: Bringing It All Back Home. New York City: Columbia, 1965. 1 disco sonoro. Lado A, faixa 1.

DYLAN, Bob. Things have changed. In: Vários. Wonder Boys (Original Soundtrack). New York City: Sony Music, 2000. 1 CD, faixa 1.

BAIA, Maurício; MOURA, Gabriel. Tá tudo mudando. In: RAMALHO, Zé. Tá Tudo Mudando. Rio de Janeiro: EMI, 2008. 1 CD, faixa 3.

DONOVAN. Atlantis. In: Barabajagal. New York City: EMI, 1969. 1 disco sonoro. Lado B, faixa 3.

RAMALHO, Zé. Meninas de albarã. In: Zé Ramalho. Rio de Janeiro: CBS, 1978. 1 disco sonoro. Lado B, faixa 4.

RAMALHO, Zé. Jardim das acácias. In: A Peleja do Diabo com o Dono do Céu. Rio de Janeiro: CBS, 1979. 1 disco sonoro. Lado B, faixa 3.

RAMALHO, Zé. Chão de giz. In: Zé Ramalho. Rio de Janeiro: CBS, 1978. 1 disco sonoro. Lado $A$, faixa 3.

RAMALHO, Zé. Adeus $2^{a}$ feira cinzenta. In: Zé Ramalho. Rio de Janeiro: CBS, 1978. 1 disco sonoro. Lado B, faixa 3.

VELOSO, Caetano. Alegria, alegria. In: Caetano Veloso. Rio de Janeiro: Philips, 1967. 1 disco sonoro. Lado A, faixa 4. GIL, Gilberto. Domingo no parque. In: Gilberto Gil. Rio de Janeiro: Philips, 1968. 1 disco sonoro. Lado B, faixa 5.

LOBO, Edu; CAPINAM. Ponteio. In: LOBO, Edu. Edu. Lobo. Rio de Janeiro: Philips, 1967. 1 disco sonoro. Lado A, faixa 1. 
RAMALHO, Zé. Eternas ondas. In: Força Verde. Rio de Janeiro: CBS, 1982. 1 disco sonoro. Lado A, faixa 2.

CÔRTES, Lula; RAMALHO, Zé. Não existe molhado igual ao pranto. In: Paêbirú - Caminho da Montanha do Sol. Recife: Rozenblit, 1974. 2 discos sonoros. Disco 1, lado B, faixa 2.

MAUTNER, Jorge; RECIFE, Robertinho de. Encantador de serpentes. In: MAUTNER, Jorge. Bomba de Estrelas. Rio de Janeiro: Warner, 1981. 1 disco sonoro. Lado B, faixa 1.

RAMALHO, Zé. Sinais. In: Sinais dos Tempos. Rio de Janeiro: Avôhai, 2012. 1 CD, faixa 2.

RAMALHO, Zé. Olhar alquimista. In: . Sinais dos Tempos. Rio de Janeiro: Avôhai, 2012. 1 CD, faixa 4.

RAMALHO, Zé. O começo da visão. In: Sinais dos Tempos. Rio de Janeiro: Avôhai, 2012. 1 CD, faixa 8.

RAMALHO, Zé. Indo com o tempo. In: Sinais dos Tempos. Rio de Janeiro: Avôhai, 2012. 1 CD, faixa 1.

RAGOVOY, Jerry. Time is on my side. In: The Rolling Stones. 12 X 5. New York City: ABKCO Records, 1964. 1 disco sonoro. Lado A, faixa 4.

RAMALHO, Zé. Lembranças do primeiro. In: Sinais dos Tempos. Rio de Janeiro: Avôhai, 2012. 1 CD, faixa 3.

GILMOUR, David; MASON, Nick; WATERS, Roger; WRIGHT, Richard. Echoes. In: Pink Floyd. Meddle. New York City: Parlophone, 1971. 1 disco sonoro. Lado B, faixa 3.

RAMALHO, Zé. A noite branca. In: . Sinais dos Tempos. Rio de Janeiro: Avôhai, 2012. 1 CD, faixa 9.

RAMALHO, Zé. Noite preta In: Zé Ramalho. Rio de Janeiro: CBS, 1978. 1 disco sonoro. Lado A, faixa 4. 
LEEUWEN, Robbie van. Venus. In: Shoking Blue. At Home. Amsterdam: Pink Elephant, 1969. 1 disco sonoro. Lado A, faixa 6.

RAMALHO, Zé. A terceira lâmina. In: A Terceira Lâmina. Rio de Janeiro: CBS, 1980. 1 disco sonoro. Lado A, faixa3.

RAMALHO, Zé. Rio Paraíba. In: Sinais dos Tempos. Rio de Janeiro: Avôhai, 2012. 1 CD, faixa 11.

RAMALHO, Zé. O que ainda vai nascer. In: Sinais dos Tempos. Rio de Janeiro: Avôhai, 2012. 1 CD, faixa 5.

RAMALHO, Zé. Portal dos destinos. In: Sinais dos Tempos. Rio de Janeiro: Avôhai, 2012. 1 CD, faixa 10.

RAMALHO, Zé. Justiça cega. In: Sinais dos Tempos. Rio de Janeiro: Avôhai, 2012. 1 CD, faixa 6.

RAMALHO, Zé. Anúncio final. In: . Sinais dos Tempos. Rio de Janeiro: Avôhai, 2012. 1 CD, faixa 12.

MAUTNER, Jorge; JACOBINA, Nelson. Maracatu atômico. In: MAUTNER, Jorge. Jorge Mautner. Rio de Janeiro: Polydor, 1974. 1 disco sonoro. Lado B, faixa 6.

AZEVEDO, Geraldo; VALENÇA, Alceu; RAMALHO, Zé. Táxi lunar. In: AZEVEDO, Geraldo. RAMALHO, Elba. RAMALHO, Zé. O grande encontro 3. São Paulo: BMG, 1998. 1 CD, faixa 2.

RAMALHO, Zé. Bicho de 7 cabeças. In: Zé Ramalho. Rio de Janeiro: CBS, 1978. 1 disco sonoro. Lado A, faixa 2.

AZEVEDO, Geraldo; RAMALHO, Zé; ROCHA, Renato. Bicho de 7 cabeças II. In: AZEVEDO, Geraldo. RAMALHO, Elba. RAMALHO, Zé. O grande encontro 2. São Paulo: BMG, 1997. 1 CD, faixa 8.

RAMALHO, Zé; CHITÃOZINHO; XORORÓ. Sinônimos. In: RAMALHO, Zé. Duetos. Rio de Janeiro: Sony Music, 2009. 1 CD, faixa 2.

AZEVEDO, Geraldo. Mister Mistério. In: VALENÇA, Alceu; AZEVEdO, Geraldo. Quadrafônico. São Paulo: Copacabana, 1972. 1 disco sonoro. Lado A, faixa 3. 
RAMALHO, Zé. Frágil. In: Por Aquelas Que Foram Bem Amadas. Rio de Janeiro: CBS, 1984. 1 disco sonoro. Lado B, faixa 2.

RAMALHO, Zé. Made in PB. In: Por Aquelas Que Foram Bem Amadas. Rio de Janeiro: CBS, 1984. 1 disco sonoro. Lado B, faixa 1.

AZEVEDO, Geraldo; RAMALHO, Zé. Pedras e moças. In: RAMALHO, Zé. Opus visionário. Rio de Janeiro: CBS, 1986. 1 disco sonoro. Lado B, faixa 5.

AZEVEDO, Geraldo; RAMALHO, Zé. Miragens. In: AZEVEDO, Geraldo. RAMALHO, Elba. RAMALHO, Zé. O grande encontro 2. São Paulo: BMG, 1997. $1 \mathrm{CD}$, faixa 8.

COELHO, Paulo; SEIXAS, Raul. Medo da Chuva. In: SEIXAS, Raul. Gita. Rio de Janeiro: Philips, 1974. 1 disco sonoro. Lado A, faixa 2.

MAGRÃO, Sérgio; SÁ, Luiz Carlos. Caçador de mim. In: RAMALHO, Zé. Estação Brasil. Rio de Janeiro: BMG, 2003. 2 CDs. CD 1, faixa 4.

RAMALHO, Zé. Garoto de aluguel (Taxi boy). In: A Peleja do Diabo com o Dono do Céu. Rio de Janeiro: CBS, 1979. 1 disco sonoro. Lado A, faixa 6.

RAMALHO, Zé. Amálgama. In: Força Verde. Rio de Janeiro: CBS, 1982. 1 disco sonoro. Lado B, faixa 4. 


\section{Filmografia}

PALAVRA (en)cantada. Direção: Helena Solberg. Radiante Filmes, 2008.1 DVD (86 $\mathrm{min})$.

A NOITE DO ESPANTALHO. Direção: Sergio Ricardo. Zem, 1973. 35mm, cor (100 min).

O HERDEIRO DE AVÔHAI. Direção: Elinaldo Rodrigues. Independente, 2009. 1 DVD (126 min).

TERRA EM TRANSE. Direção: Glauber Rocha. Versátil, 1967. 35mm, p\&b (106 $\min )$.

EASY RIDER. Direção: Dennis Hopper. Sony, 1969. 2 DVDs (92 min).

WOODSTOCK. Direção: Michael Wadleigh. Woodstock, 1970. 35 mm, cor (184 $\min )$.

NORDESTE: CORDEL, REPENTE E CANÇÃO. Direção: Tânia Quaresma. Filmcenter, 1975. $35 \mathrm{~mm}$, cor (68 min).

NAS PAREDES DA PEDRA ENCANTADA. Direção: Cristiano Bastos e Leonardo Bomfim. Independente, 2011. 1 DVD (120 min).

LISBELA E O PRISIONEIRO. Direção: Guel Arraes. Sony, 2003. 1 DVD (106 $\min )$. 